\title{
A COHAB-SP e uma nova política habitacional: o período 2001-2004
}

\author{
Dissertação de Mestrado \\ Área de Pesquisa: Habitat \\ Faculdade de Arquitetura e Urbanismo da \\ Universidade de São Paulo
}

\section{Carlos Adriano Santos Constantino}

Orientador: Prof. Dr. Khaled Ghoubar

Junho, 2007 
AUTORIZO A REPRODUÇÃO E DIVULGAÇÃO TOTAL OU PARCIAL DESTE TRABALHO, POR QUALQUER MEIO CONVENCIONAL OU ELETRÔNICO, PARA FINS DE ESTUDO E PESQUISA, DESDE QUE CITADA A FONTE.

ASSINATURA:

E-MAIL: c_adriano_sc@yahoo.com.br

Constantino, Carlos Adriano Santos

C758c A COHAB-SP e uma nova política habitacional: o período

2001-2004 / Carlos Adriano Santos Constantino. --São Paulo,

2007.

245 p. : il.

Dissertação (Mestrado - Área de Concentração: Habitat) FAUUSP.

Orientador: Khaled Ghoubar

1.Conjuntos habitacionais - São Paulo(SP) 2.Política habitacional 3.Mutirão 4.Autogestão I.Título

CDU 711.582(816.11) 


\section{Dedicatória}

Dedico aos meus maiores amores: Sônia, Otávio, Dona Nice e Seu Beto. E, meio presunçoso e meio piegas (mas assumido), a todos que batalham por igualdade com democracia. 


\section{Agradecimentos}

Engenheiro civil de formação (UNICAMP) e com uma inclinação para a arquitetura e o urbanismo, e participante (não tanto quanto desejava, mas tanto quanto podia) de alguns movimentos que batalhavam por moradia e pela cidade em geral (Sem Teto de Lausanne Paulista e Imirim, Sem Casa, Reforma Urbana), fui parar, por desígnios da escassez de empregos, mas também por um certo desejo, em prefeituras (Olímpia, Limeira, São Paulo e Franco da Rocha) e empresas (EMTU, CDHU e COHAB$\mathrm{SP}$ ) onde se trabalhava com córregos que transbordavam, ruas que não permitiam transitar, com transporte coletivo e habitação popular. Para continuar a minha formação, vim para a Pós da FAUUSP.

Nessas passagens, que às vezes achava meio desconexas, mas que hoje parece que se encaixam mais ou menos bem, participei de trabalhos que deram e, ainda, dão muita gratificação. Mas, muito maior do que a satisfação pelos resultados, é a de ter podido conviver com uma porção de pessoas da maior qualidade, que contribuíram muito para este trabalho, mas, mais do que isso, para a minha vida. Vou agradecer a muitas delas, correndo o risco de deixar de mencionar algumas também importantes, e sabendo que este trabalho, infelizmente, não faz jus ao tamanho dessas contribuições.

Agradeço:

Em especial, ao Khaled Ghoubar, pela orientação, estímulo e amizade.

Aos professores Philip Gunn (“in memorian”), Ermínia Maricato, Maria Lúcia Refinetti Martins, por tudo que ajudaram, também orientando e incentivando. Ao Paulo César Xavier Pereira e ao Ricardo Moretti, pelas sugestões no Exame de Qualificação.

À Ângela Amaral, Carolina Pozzi de Castro, Cibele Vieira, Liliana Jalfen, Lucimar Ferreira, Maria Lúcia D’Alessandro, Márcio Penteado, Maria Rita Cartillone, Sylvia Ammar Forato, pelo estímulo, leitura dos rascunhos e muitas e importantes sugestões (algumas não incorporadas por falta de tempo). Ainda à Malú D'Alessandro e também à lara Serafim e à Mariana Lettis, pela ajuda na digitação e formatação.

Ao André G. Lobo, Berta Alves Costa, Cecília Luchese, Flávio Almeida, Flávio Marcondes Soares, Gabriel Blanco, José Paulo Vieira, Gustavo Della Nocce, Laura Bueno, Lia A. F. Barros, Luciana Royer, Lúcia Nakazone, Luiz Macarrão, Maria do Rosário Ramalho, Maria do Socorro Pinho, Mariângela Portela da SIlva, Marta Junqueira, Mitchiko Schiroma de Carvalho, Nabil Bonduki, Núria Vieira, Paulo Giaquinto, Regina Grimaldi, Reynaldo Cué (“in memorian”), Rosélia Ikeda, Rossella Rossetto, Rui 
Pereira dos Santos Jr., Sônia Calió, Stella Bilemjian, Thania Blaser, Vera Alvarenga, pelo incentivo e pela troca de idéias.

À turma de HABI-SEHAB, sobretudo, Ermínia Maricato e Nabil Bonduki, por aqueles tempos "gloriosos" (1989-1992), de pouca experiência, mas de muita vontade de acertar e de muito aprendizado.

Ao conjunto dos funcionários da COHAB-SP e da SEHAB, pela possibilidade de ter compartilhado das experiências do período 2001-2004, mas, principalmente, àqueles com que convivi mais de perto, como: o Paulo Teixeira, Marcos Barreto, Jorge Hereda, Ricardo Schumann, Suely Muniz, André Leonardi, Mozart Moraes, Emílio Alonso, Manoel Vítor Figueiredo, Altemir Almeida, Arlete Moysés, Cecília L. P. Fontes, Gloria S. Kono, José Carlos Gomes de Sá, Paulino Caetano, Alessandra Viera, Alexandre Hodapp, Alexandre Tanaka, Annacláudia Rosbach, Benedito Barbosa, Carla Canelas, Carlos Miaciro, Celso Carvalho, Celso Sampaio, Cibele Vieira, Daniel Amor, Dora Reis, Emilene Miossi, Fernando Aith, Francisca Teixeira, Gabriel Blanco, Geraldo Jacob Jorge, Gerson Ponciano, Gisela Mori, Helen Moraes, Helena Menna Barreto Silva, Inês Bertão, Jorge Menneh, Laila Mourad, Liliana Jalfen, Luís Jacometti, Marcos Fialho, Maria Lúcia D'Alessandro, Margareth Uemura, Marise L. Franco, Mylene Gambale, Patrick Carvalho, Paula Lara, Raimundo Bonfim, Regina Orsi, Renata Milanezi, Ricardo Luppi, Rômulo Andrade, Rosélia Ikeda, Rubens Liberatti, Sandra Simões, Sérgio Gonçalves, Sidney Piochi, Sylvia Forato, Tereza Herling, Wagner Germano.

À turma da GPP II, da CDHU, principalmente, ao Moysés Aldo do Nascimento e ao Luiz Cláudio Pettian, mas também à Ana Elisa, Ana Maria Coelho, Antônio Kitakawa, Artur Lozano, Bebel Bertoncello, Cláudia Lacorte, Cláudio Gonçalves, Daniel Barbieri, Elias Flores, lara Serafim, Jorge Azevedo, José Yukio, Juliana Silva, Luiz Carlos Lopes, Marcelo Dias, Michele Azevedo, Sandra Taytie, Rosano Silva, Sérgio Ueno e ao Thiago.

À Estelita, Maria José, Sonia Parlatore e Alba Pitanginsky, por me facilitarem o acesso à bibliografia, e à Dona Cida, Isa e Cristina, pela paciência na secretaria.

À Juliana Jacometto, Maria Cristina Brito e Rubênio Simas, pelo fornecimento de dados, fotos e desenhos.

À turma da Casa da Cidade, principalmente, Nabil, Malú, Sylvinha, João Marcus, Vanderlei Rodrigues, Wagner Romão, Lica Dias, Marisa Blanco, Andrea Piccini, Estefânia, Hellen e Selma, por desculparem minhas ausências e segurarem as pontas.

À Sônia, Otávio, Sandra, Lulu e Aída, por todo o incentivo, pela compreensão e pelo tanto que me pouparam de muitos trabalhos em casa. 


\section{Urbaniza-se? Remove-se?}

São 200, 300

as favelas cariocas?

tempo gasto de contá-las

é tempo de surgirem.

800 mil favelados

ou já passa de um milhão?

Enquanto se contam, ama-se

em barraco e a céu aberto,

novos seres se encomendam

ou nascem à revelia.

Os que mudam, os que somem, os que são mortos a tiro são logo substituídos. Onde haja terreno vago, onde ainda não se ergueu um caixotão de cimento esguio (mas vai-se erguer) surgem trapos e tarecos, sobe fumaça de lenha em jantar improvisado.
Urbaniza-se? Remove-se? Extingue-se a pau e fogo? Que fazer com tanta gente brotando do chão, formigas de formigueiro infinito? Ensinar-lhes paciência, Conformidade, renúncia? Cadastrá-los e fichá-los para fins eleitorais?

Prometer-Ihes a tão sonhada, mirífica, róseo-futura distribuição (oh!) de renda? Deixar tudo como está para ver como é que fica? Em seminários, simpósios, comissões, congressos, cúpulas ${ }^{1}$ de alta vaniloquência elaborar a perfeita e divina solução?
Um som de samba interrompe tão sérias cogitações, e a cada favela extinta ou em vila transformada, com direito a pagamento de Comlurb, ISS, Renda, outra aparece, larvar, rastejante, desafiante, de gente que nem a gente, desejante, suspirante, ofegante, lancinante. O mandamento da vida explode em riso e ferida.

\section{Carlos Drummond de Andrade $^{2}$} (1984, apud OLIVEIRA; Nelson, 2007, p. 207)

\footnotetext{
${ }^{1}$ Será que o poeta se esqueceu das teses e dissertações como esta? Que, como os seminários, simpósios, etc, tentam não ser vanilóquios, mas nem sempre conseguem.

2 ANDRADE, Carlos Drummond. "Favelário Nacional", do livro "Corpo". Editora Record, 1984
} 


\section{Resumo}

Este trabalho aborda a atuação da Companhia Metropolitana de Habitação de São Paulo -COHAB-SP-, em vários momentos de sua história, observando mudanças que sofreu desde que foi constituída, como agente promotor do SFH, até hoje. E foca mais suas observações no desempenho desse órgão na esfera da provisão habitacional e no período 2001-2004, quando participou da implementação de uma política habitacional marcada por diferenças significativas em relação àquelas dos períodos precedentes. Diferenças que se verificaram no desenvolvimento de novas tipologias de projeto (terrenos menores e mais centrais, reforma de prédios, etc.), na implantação de novos programas habitacionais (moradia na área central, locação social, bolsa aluguel, etc.), na sua consolidação como agente operador do Fundo Municipal de Habitação, no papel ativo que desempenhou na busca de novas fontes de recursos (Ministério das Cidades (PSH e PEHP), CEF/PAR, CDHU, BID, etc) e em uma maior interlocução com movimentos e associações comunitárias. Este trabalho busca compreender potencialidades e limitações dessa Companhia, na solução dos problemas de habitação para população de baixa renda em sua área de abrangência, mas, sobretudo, no Município de São Paulo, onde tem um papel relevante, dentre os vários órgãos de provisão habitacional. 


\section{Abstract $^{3}$}

This thesis examines the experience of the Metropolitan Housing Agency of the city of São Paulo (COHAB-SP, for its name in Portuguese) in different periods of its history and detects changes that took place since its origin, as an agent of the Brazilian Housing Finance System (SFH, for its name in Portuguese), until the present day. It focuses mainly on this agency's performance in the provision of housing and on the period of 2001-2004, when it implemented a housing policy which represented a significant departure from past practice. These differences may be observed in new project typologies (smaller and more centrally located plots, building reform, etc.) and new housing programs (central-area housing, public rental housing, rent subsidies, etc.), as it asserted its role as an operational agent of the Municipal Housing Fund, in the active pursuit of new funding sources (Ministry of Cities; CEF, the federal government's savings bank; IDB, etc.) and a greater dialogue with social movements and community organizations. The research attempts to determine the potentialities and limitations of the agency in the solution of problems related to the provision of low-income housing in its metropolitan sphere of influence, but mainly in the city of São Paulo, where it plays an important role among the different agencies involved in the provision of housing.

\footnotetext{
${ }^{3}$ Esta tradução do Resumo, mais uma gentileza de uma pessoa sempre gentil —apesar de um exaltado defensor de ideais-, deve ter sido um dos últimos trabalhos do colega, amigo e companheiro Reynaldo Cué, que quis primeiro comemorar o Dia do Trabalho, antes de falecer em 2/5/2007.
} 


\section{Sumário}

\begin{tabular}{ll}
\hline Dedicatória & 1
\end{tabular}

\begin{tabular}{ll}
\hline Agradecimentos & 2
\end{tabular}

Epígrafe 4

Resumo 5

\begin{tabular}{ll}
\hline Abstract & 6
\end{tabular}

\begin{tabular}{ll}
\hline Sumário & 7
\end{tabular}

$\begin{array}{ll}\text { Introdução } & 9\end{array}$

Capítulo 1: Elementos da história da COHAB-SP e das políticas 17 habitacionais do município de São Paulo

1.1. Dimensões e principais características das intervenções 23 promovidas pela COHAB-SP

1.2. A atuação de HABI e o FUNAPS 28

Capítulo 2: As críticas mais freqüentes ao antigo modelo COHAB 36

2.1. Políticas de aquisição de terras - a expansão para os 37 extremos da cidade

2.2. Projetos - a padronização excessiva 40

2.3. Obras - o predomínio da ótica das construtoras $\quad 47$

2.4. A irregularidade dos empreendimentos 49

2.5. Críticas formuladas por partidos políticos 50

Capítulo 3: As condicionantes da política habitacional implantada entre 52 2001 e 2004

3.1. A demanda por habitação social em São Paulo, segundo 52 o Plano Municipal de Habitação de 2004

3.2. As idéias que a nova gestão trazia 55

3.3. A situação da COHAB-SP e da Prefeitura no início de 59 2001 
Capítulo 4: O desenho da nova política habitacional

4.1. O que se planejou para o período 2001-2004

4.1.1. O planejamento feito pela COHAB

4.1.2. A $1^{\mathrm{a}}$. Conferência Municipal de Habitação

4.2. O quadro geral dos programas

4.3. Os recursos financeiros

4.4. O Fundo Municipal de Habitação e seu Conselho

Capítulo 5: A execução pela COHAB-SP da sua parte na política 120 habitacional

5.1. As terras de que se dispunha e o processo de aquisição 120 de novos imóveis para a produção habitacional

5.2. O desenvolvimento dos projetos

5.3. O Programa de Mutirões com Autogestão

5.4. O Programa de Arrendamento (PAR) em parceria com a 172 CEF

5.5. Os Programas Morar no Centro e de Locação Social

Capítulo 6: Alguns paralelos 


\section{Introdução}

Pelos dados das pesquisas ou pelo simples olhar para as favelas, cortiços, loteamentos irregulares, baixos de viaduto, conjuntos habitacionais de promoção pública muito degradados, o problema da habitação de interesse social no Brasil toma dimensões tão grandes que parece que não estaria ao alcance do país a possibilidade de resolvê-lo ${ }^{1}$. Movimentos sociais têm formulado e se mobilizado em torno de propostas, muitas políticas públicas têm sido postas em execução, recursos consideráveis têm sido disponibilizados, muitos estudos em torno da questão têm sido desenvolvidos por pesquisadores da maior seriedade e qualificação. No entanto, continua parecendo que é um problema sem possibilidade de solução e que as instituições envolvidas com habitação de interesse social estariam "enxugando gelo", assistindo à proliferação de assentamentos sub-normais, o seu avanço sobre áreas que deveriam ser protegidas por responsabilidade ambiental (mananciais, córregos, mangues, morros, matas, etc.), e o agravamento da justaposição do drama ambiental ao drama social. Esse último, evidentemente, atinge mais os moradores desses assentamentos, mas também a sociedade como um todo, no mínimo, pelos seus efeitos sobre o crescimento da violência urbana.

Geralmente, aponta-se como maiores entraves para a execução de políticas habitacionais eficazes: a escassez ou descontinuidade do fluxo de recursos; os aspectos tecnológicos (o discutível "atraso" da construção civil no país) ${ }^{2}$; a legislação desfavorável ou a falta de vontade política para fazer cumprir a legislação existente, sobretudo aquela relacionada à função social da propriedade ${ }^{3}$; e em última instância, do tipo de capitalismo que se instalou no país, cuja ação não foi atenuada pela efetiva presença de um Estado do Bem-Estar Social, como

\footnotetext{
1 No Brasil, há um déficit quantitativo de 7,9 milhões de domicílios e 1,96 milhão de domicílios em favelas (IBGE, PNAD-2005, apud Ministério das Cidades). Apesar de serem números elevados, são inferiores, por exemplo, aos 13 milhões de domicílios que constituíam o déficit verificado na França em 1945 (FARAH, 1990, p. 13), e que se conseguiu equacionar.

2 Newton VARGAS (!983) e Marta FARAH (1996) são dois dos autores que mais discutem a idéia do "atraso".

3 As razões do hiato que se verifica nas cidades, entre as leis aprovadas e as leis aplicadas, ou, em suas palavras, do "descolamento entre a ordem legal e a cidade real" são abordadas por Ermínia MARICATO, em “A Metrópole na Periferia do Capitalismo" (1996).
} 
ocorreu em muitos países que conseguiram equacionar seus graves problemas habitacionais.
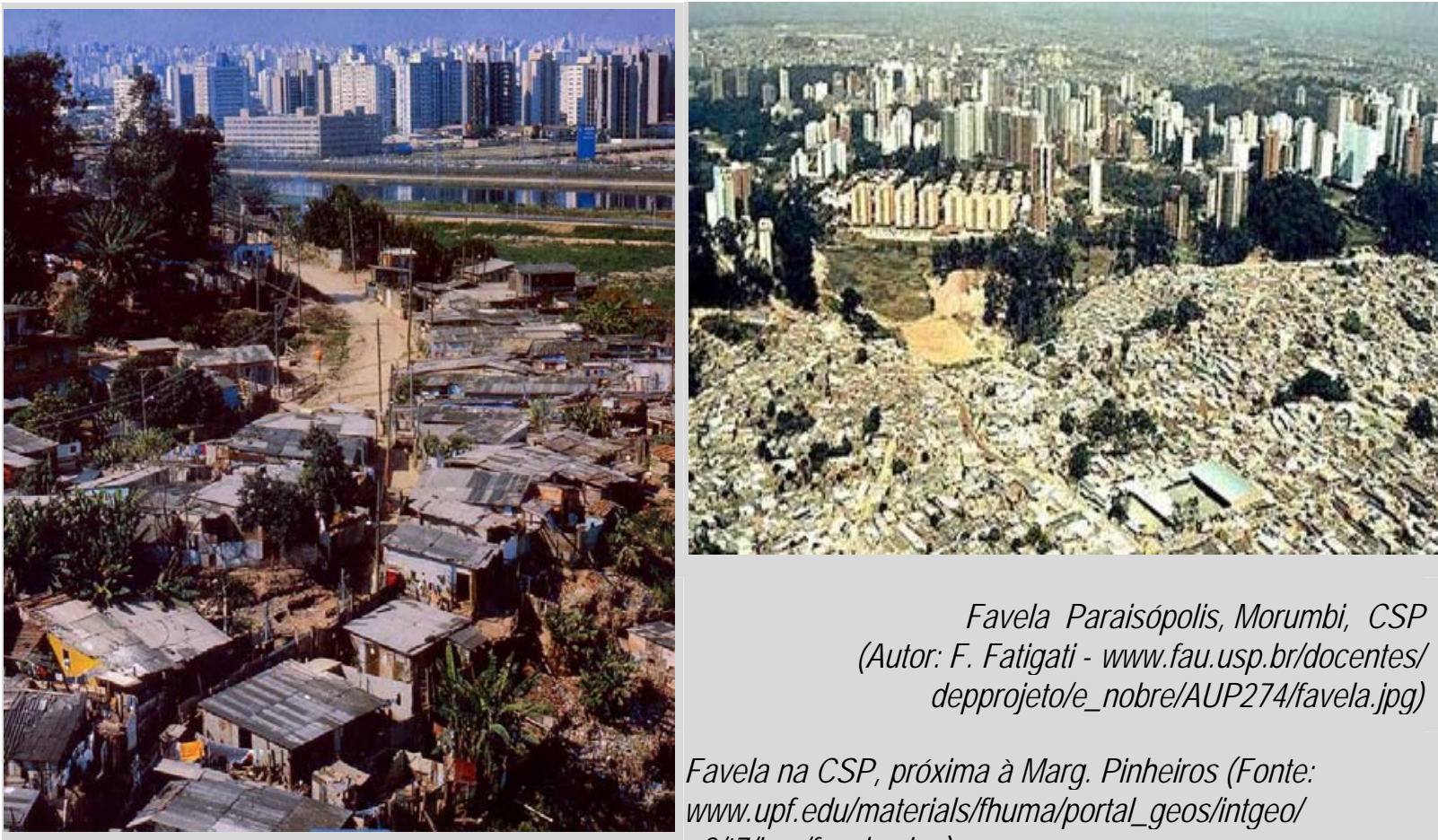

Favela na CSP, próxima à Marg. Pinheiros (Fonte: www.upf.edu/materials/fhuma/portal_geos/intgeo/ g2/t7/img/favelas.jpg)

Mas tem sido objeto de poucas observações e estudos um fator que, muitas vezes, representa um entrave importante: a forma como têm atuado, as empresas e órgãos públicos responsáveis pela formulação e execução de políticas e programas para a área de habitação de interesse social. Em certos momentos dessas empresas e órgãos, tem se verificado, inclusive, grande dificuldade em gastar recursos duramente obtidos. Trabalhando em alguns desses órgãos (SEHAB/HABI, CDHU e COHAB-SP), pudemos observar a falta que se sentia de um maior número de avaliações mais completas sobre o trabalho realizado, que permitissem ou orientar mudanças de rumo ou confirmar a correção do rumo adotado. Há um certo paradoxo nessa escassez de avaliações, considerando toda a produção acadêmica em torno de outros aspectos da habitação de interesse social.

Se há muita discordância, no meio da sociedade, sobre a conveniência do Estado participar como investidor em vários setores da economia e essa discordância é um ponto crucial do debate político e econômico; em relação à questão da habitação social, há pouca discordância sobre a importância do papel do Estado. 
Incluindo desde entidades empresariais, como o SINDUSCON-SP (Sindicato da Indústria da Construção Civil do Estado de São Paulo), até os movimentos populares, há um coro a favor da continuidade de programas públicos, junto com a reivindicação por um maior volume e regularidade na liberação de recursos. É claro que é um coro nem sempre afinado e harmônico, inclusive, porque essas entidades e movimentos, geralmente, disputam entre si parcelas dos fundos públicos.

A participação do Estado na provisão habitacional e na melhoria das condições de habitabilidade das moradias existentes tem variado ao longo do tempo, mas, até hoje, mantém como central a atuação de órgãos estatais da administração direta, como as secretarias estaduais e municipais de habitação, e empresas da administração indireta, como a CDHU e as COHAB's.

Esses órgãos e empresas têm produzido em quantidade menor do que a necessária, muitas vezes, nos lugares errados e com baixa qualidade. Além disso, produzem grandes porções de cidade e interferem fortemente nas outras porções já existentes. E, na construção, não se encerra a sua participação, pois continuam a ter responsabilidades em relação aos conjuntos habitacionais mesmo depois de ocupados. Mas, por outro lado, também produziram um número considerável de moradias, contribuindo para que não se expandissem, mais ainda, os déficits de habitação e de habitabilidade nas moradias existentes.

Esta dissertação aborda a atuação, na esfera da produção de novas moradias, da COHAB-SP, responsável por grande parcela da provisão habitacional para população de baixa renda, na cidade de São Paulo e em sua região metropolitana. Focando o período da gestão da prefeita Marta Suplicy (2001-2004), durante o qual a Companhia passou por mudanças importantes, busca-se uma análise de como ela realizou a sua parte no trabalho de implementação de uma nova política habitacional.

A atuação da Prefeitura na área da habitação sob a gestão Marta Suplicy era cercada por grande expectativa colocada pelos movimentos populares que lutam por habitação -os mais organizados da cidade-, e pelo grupo de técnicos vinculados aos partidos que haviam apoiado a candidata. Expectativas sobre uma forte atuação 
na área de habitação, que ampliasse a urbanização e a regularização de favelas e de loteamentos irregulares; que promovesse melhorias em conjuntos habitacionais existentes e deteriorados; que introduzisse novos programas destinados a promover a habitação social no Centro da cidade; que aumentasse a escala da produção habitacional, garantindo boa qualidade de projeto e construção; e que fosse feita com participação popular.

Essas expectativas tinham suas razões. A despeito da esperada escassez de recursos, havia condições favoráveis: uma tradição de priorizar a habitação em vários governos petistas, como havia ocorrido na gestão Erundina; a força e o engajamento dos movimentos populares e a idéia de que teriam uma boa interlocução com a nova administração; a homogeneidade de concepções políticas e técnicas nas novas equipes dirigentes da SEHAB e COHAB, da qual se esperava que resultaria uma afinação entre esses dois organismos, como poucas vezes houvera antes em sua história (e pode-se dizer que isso de fato aconteceu). Além disso, contribuíam para o quadro de expectativas positivas: o Projeto Moradia, que havia sido elaborado pelo Instituto Cidadania, e o Estatuto da Cidade, que estava tramitando e cuja aprovação era esperada no Congresso. O Projeto Moradia avançava em relação a outros documentos que tinham objetivos semelhantes, ao definir um horizonte de atuação no qual os déficits de habitações e de habitabilidade seriam equacionados, projetando o crescimento da demanda, apontando os montantes de recursos necessários e suas fontes, e indicando o desenho institucional que seria adequado para atacar a questão.

A proposta deste trabalho de olhar para a atuação de um conjunto de programas da COHAB-SP apresentava uma dificuldade de bom tamanho. Muitas vezes, pareceu que a abertura do foco era excessiva e que deveria estudar com maior profundidade apenas um dos aspectos abordados, um programa ou um empreendimento somente. Mas a lente grande angular pode ter alguma vantagem. Uma panorâmica seria importante para tentar captar, em certa medida, como emergiam e como eram tratados os vários problemas cuja solução, de forma mais específica, competia à $\mathrm{COHAB}$, mas, de forma mais geral, também às outras partes da SEHAB. E esse "captar" mais do que fornecer elementos para uma análise por este trabalho pode talvez oferecer, para análises futuras, registros de questões e pontos que tenderiam a se perder. 
Cada um dos programas e projetos observados mereceria um estudo mais detido, no entanto, a intenção era olhar para o andamento simultâneo desses vários programas e as questões e dificuldades que esse andar apresentava. Isso porque, a meu ver, impulsionar esse andar simultâneo é onde mora a maior dificuldade. E esse era o trabalho de um conjunto de agentes constituído basicamente da SEHAB, da COHAB, do Conselho Municipal de Habitação e das várias partes de que são compostos. E a divisão de trabalho e a forma de interagir dessas várias partes, também, se constituiu (e, de certa maneira, ainda se constitui) num outro problema a ser resolvido.

Um exemplo de como as várias ações e decisões e as suas mútuas interferências aconteciam pode ser vista nas agendas de reuniões, em que os mesmos gestores estavam envolvidos, tratando sucessivamente: de campanhas para renegociar contratos, visando reduzir a inadimplência em conjuntos já existentes; de incêndios em favelas e como construir (e depois manter) os alojamentos provisórios, com a rapidez e qualidade exigidas; de projetos de novos conjuntos habitacionais; da viabilidade de novos métodos construtivos; de formas de se evitar o repasse ("revenda") das unidades habitacionais oferecidas, buscando a permanência da população inicialmente atendida; etc., etc. É importante ressaltar que, mesmo não tendo como atribuição responder às emergências na área de habitação, que eram de responsabilidade das subprefeituras ou de $\mathrm{HABI}$, em muitas situações, a COHAB acabou se envolvendo fortemente no momento seguinte ao atendimento emergencial, por exemplo, na construção dos já mencionados alojamentos provisórios ou na concessão de bolsa-aluguel.

Como já foi dito, do conjunto de aspectos relacionados à atuação da COHAB-SP, no período 2001-2004, o foco principal desse trabalho será a produção de novas moradias, processo que envolve a definição da demanda a ser atendida, a aquisição de terras, a elaboração e aprovação de projetos, a execução de obras. O que se pretende é observar o ritmo de produção de novas moradias, e a forma como se buscou garantir o atendimento aos requisitos de qualidade, custos compatíveis e de participação popular, nas várias etapas do processo.

Desejava-se, no começo desta empreitada, e ainda se deseja, observar as possibilidades de combinar qualidade, custos controlados e participação popular 
com agilidade e produção de moradias em larga escala. Uma suposta incompatibilidade entre esses fatores é uma questão que precisaria ser melhor estudada, pois a não explicitação dessas questões acaba levando a escolhas entre uma coisa ou outra, quando não necessariamente teriam que ser excludentes.

Os objetivos da pesquisa que é resumida por esta dissertação parece que são muito maiores que as condições (sobretudo de tempo) de que se dispõe no mestrado. No entanto, resolveu-se mantê-los sabendo do risco que se corria de deixar muitas lacunas, de errar por falta de aprofundamento e/ ou por falta de ampliação do ângulo de visão, deixando de fora da observação fatores que também seriam relevantes. Uma avaliação como a que se esboça aqui teria que ser tarefa de um grupo de pesquisadores.

Mesmo correndo os riscos de superficialidade, decidiu-se por fazer essa pesquisa, principalmente, pela preocupação com a carência ou dispersão de registros mais detalhados sobre os processos de implantação de políticas/programas habitacionais; com a escassez de avaliações sobre essas implantações; com uma falta de sistematização do conhecimento sobre as estruturas, processos, prazos e custos das instituições envolvidas na implementação de programas habitacionais (órgãos públicos contratantes, projetistas, construtoras, ONG's e associações conveniadas). E também por considerar que essas carências de informações teriam contribuído muito para a dificuldade na implementação dos programas propostos (às vezes, mais até do que a falta de recursos financeiros), levando a improvisações, repetição de erros já cometidos, atrasos, etc.

Houve uma preocupação, durante a elaboração desta dissertação, com a possibilidade de que, ao apontar, para alguns aspectos negativos (ou em torno dos quais havia dúvidas) das políticas e dos trabalhos realizados na COHAB-SP, ficasse a impressão de que estariam sendo criticadas as pessoas que participaram de sua execução. Efetivamente, não há críticas às pessoas que participaram dos trabalhos na $C O H A B$ e na SEHAB. Nem teria porque haver e nem seria justo. Até porque o autor desta dissertação também trabalhou na COHAB-SP, no período sobre o qual está o seu foco principal, e testemunhou o empenho, a grande dedicação e a capacidade de trabalho da grande maioria dos profissionais envolvidos com ele. 
É bem delicada a análise pretendida nesse trabalho, principalmente, pelo forte envolvimento do observador com o objeto observado. No entanto, houve um grande esforço por manter isenção e, para que nesse esforço, ao tentar calibrar os elogios, não se passasse a carregar nas cores dos aspectos negativos. Esforço que ainda não há como saber se foi bem sucedido.

Esta dissertação foi montada da forma descrita a seguir:

No Capitulo 1 -Elementos da história da COHAB-SP e das políticas habitacionais do município de São Paulo-, será abordada a atuação da COHAB ao longo da sua história e sua relação com a política habitacional definida pelo Sistema Financeiro da Habitação (SFH), da qual era integrante, e, em paralelo, a atuação de outros órgãos municipais envolvidos com o atendimento habitacional, principalmente, a HABI.

No Capítulo 2 -As críticas mais freqüentes ao antigo modelo COHAB-, serão expostas as críticas que, mais amiúde, eram feitas ao modelo de atuação pelo qual a COHAB pautou-se na maior parte de sua história. As críticas às políticas de aquisição de terras, aos projetos, às obras, à irregularidade dos empreendimentos, etc., que influenciaram as mudanças propostas para a Companhia a partir de 2001.

\section{No Capítulo 3 -As condicionantes da política habitacional implantada} entre 2001 e 2004-, serão discutidas as principais circunstâncias, os principais fatores que influenciaram a política habitacional implementada entre 2001 e 2004, pela Prefeitura de São Paulo. Dentre esses fatores: a demanda por habitação social existente na cidade; a situação em que se encontrava a PMSP, a SEHAB e a COHAB, no final de 2000; e o conjunto de idéias que a nova gestão trazia: as concepções que brotaram no período pós-BNH, em que passou a ocorrer uma "municipalização das políticas habitacionais"4; as propostas formuladas em gestões anteriores do PT (em São Paulo e em outros municípios) e presentes no Programa de Governo da Prefeita Marta Suplicy, concebido no Instituto Florestan Fernandes, e no Projeto Moradia, elaborado no Instituto Cidadania.

\footnotetext{
${ }^{4}$ CARDOSO e RIBEIRO
} 
No Capítulo 4-O desenho da nova política habitacional-, será abordado o desenho geral da política habitacional adotada pela PMSP, no período 2001-2004, considerando: o que foi planejado pela SEHAB e pela COHAB; as propostas da $1^{a}$. Conferência Municipal de Habitação; os recursos financeiros existentes; e a constituição e o funcionamento do Conselho e do Fundo Municipal de Habitação.

No Capítulo 5 - A execução pela COHAB-SP da sua parte na política habitacional-, serão expostos e discutidos os principais programas de provisão habitacional da COHAB, que são os de Mutirões com Autogestão, de Arrendamento Residencial (PAR), Morar no Centro e Locação Social. Esses foram considerados os principais programas por envolverem ou os maiores números da produção da Companhia (Mutirões e PAR) ou as maiores inovações introduzidas (Morar no Centro e Locação Social). Nesse capítulo, também serão abordadas as terras disponíveis, as terras adquiridas e os processos de aquisição; e o desenvolvimento dos projetos (arquitetura, urbanismo e engenharia).

No Capítulo 6 -Alguns paralelos-, serão apresentadas comparações entre o que a COHAB-SP realizou, no período 2001-2004, e:

- o que havia realizado em períodos anteriores;

- as propostas do Programa de Governo de Marta Suplicy para a gestão 2001-2004;

- as metas e propostas colocadas pelo planejamento estratégico da Companhia e pela $1^{\mathrm{a}}$. Conferência Municipal de Habitação; e

- a demanda por habitação social no MSP, indicada pelo Plano Municipal de Habitação. 


\section{Capítulo 1 \\ Elementos da história da COHAB-SP e das políticas habitacionais do município de São Paulo}

A Companhia Metropolitana da Habitação (COHAB-SP) é uma sociedade anônima de economia mista, cujo controle acionário pertence à Prefeitura do Município de São Paulo (99\% das ações). Tem por objetivo atuar na provisão de habitação de interesse social tanto no município, quanto em sua Região Metropolitana. Fundada em 1965 na gestão do Prefeito Faria Lima, foi o primeiro órgão do Município de São Paulo a receber atribuições mais abrangentes quanto à provisão habitacional, tendo sua criação antecedido em aproximadamente uma década a criação da própria Secretaria da Habitação e Desenvolvimento Urbano (COHAB-SP, Relatório de Gestão, 1992, p. 5).

A COHAB-SP foi fundada seguindo diretrizes do Governo Federal, que constituíram o Sistema Financeiro da Habitação (SFH). E dessa forma, foi mais influenciada por essas diretrizes do que pelas experiências anteriores da própria Prefeitura no campo da habitação de interesse social (que serão abordadas adiante), mantendo-se, na maior parte de sua história, distante, apartada, com uma atuação muito autônoma em relação aos outros órgãos da administração municipal voltados à questão habitacional.

O SFH, sistema dentro do qual as COHAB's foram concebidas, foi responsável por grande parcela da produção habitacional do país e por um forte impulso em sua indústria de construção civil ${ }^{5}$. O SFH, criado pela Lei 4380 , de 21/08/1964, juntamente com Banco Nacional da Habitação (BNH) e com o Serviço Federal de Habitação e Urbanismo (SERFHAU) ${ }^{6}$, foi (e continua sendo) constituído de dois fundos, o FGTS e o SBPE, e teve o BNH como principal operador de suas ações.

O FGTS (Fundo de Garantia por Tempo de Serviço), instituído em 1966 (Lei 5.107), formou-se por contribuição compulsória correspondente a $8 \%$ das folhas de pagamento dos trabalhadores contratados pela CLT e se destina ao atendimento

\footnotetext{
${ }^{5}$ SACHS, 1999, p. 123.
} 
de parcelas de menor renda da população, a taxas de juros menores. O SBPE (Sistema Brasileiro de Poupança e Empréstimo) reúne recursos de poupança voluntária captados através das cadernetas de poupança, garantidas pelo Governo, e se destina à chamada faixa de mercado $^{7}$.

O BNH, criado em 1964 e extinto em 1985, foi a instituição responsável pela gestão do FGTS e pela regulação do SBPE. Mobilizou montante de recursos apenas superado pelo administrado pelo Banco do Brasil ${ }^{8}$ e financiou, de 1964 ao primeiro semestre de 1985 , a construção de 2.559 .759 moradias $^{9}$.O que corresponderia a, praticamente, $12 \%$ do total de moradias construídas no país, durante o seu período de existência, considerando informações de MARICATO (1997, p. 13). Já todo o SFH (o que inclui o $B N H)$, no mesmo período, financiou 4.392.517 moradias, nas duas linhas de financiamento (FGTS e SBPE). Em termos de produção anual, o BNH financiou a produção de, aproximadamente, 128 mil uh/ano para baixa renda e 220 mil uh/ano em todo o SFH.

No entanto, essa produção não parece tão notável, quando se observa a produção estatal de outros países. Segundo FARAH (1990, p. 14), nos "países avançados", a construção de unidades habitacionais através da promoção direta do Estado representou, em determinados períodos, mais de $50 \%$ do total construído. Segundo ARRETCHE (1990, p. 21), na Suécia,

"[.......] 87\% das novas unidades habitacionais construídas entre 1946-80 (Dickens et alii, 1985:84) foram realizadas mediante contratos estabelecidos diretamente com agências estatais - dado este que demonstra a extensão do envolvimento estatal no setor".

Na Tabela 1.1, são indicados alguns números da produção de moradia social por promoção estatal em diversos países.

\footnotetext{
${ }^{6}$ SACHS, 1999, p. 129.

${ }^{7}$ ARRETCHE, 1990, p. 24.

${ }^{8}$ CARVALHO, 2004, p. 18.

${ }^{9}$ SACHS, 1999, p. 133.
} 
Tabela 1.1 - Número de UH's produzidas por período, para população de baixa renda, por promoção estatal em alguns países

\begin{tabular}{|c|c|c|c|c|c|c|c|}
\hline País & $\begin{array}{l}\mathrm{N}^{0} \text {. uh'sl } \\
\text { período }\end{array}$ & Período & $\begin{array}{l}\mathrm{N}^{0} \text {. uh'sl } \\
\text { período }\end{array}$ & Período & $\begin{array}{l}\mathrm{N}^{0} \text {. uh'sl } \\
\text { período }\end{array}$ & Período & Fonte \\
\hline França & $320 \mathrm{mil}$ & 1959 & $520 \mathrm{mil}$ & 1973 & $250 \mathrm{mil}$ & 1985 & \multirow{6}{*}{$\begin{array}{c}\text { FARAH } \\
(1990 \text { p. } \\
14)\end{array}$} \\
\hline $\begin{array}{c}\text { Inglaterra e } \\
\text { Gales }\end{array}$ & $310 \mathrm{mil}$ & 1954 & $410 \mathrm{mil}$ & 1967 & $170 \mathrm{mil}$ & 1985 & \\
\hline $\begin{array}{c}\text { Alemanha } \\
\text { Ocidental }\end{array}$ & $390 \mathrm{mil}$ & 1950 & 700 mil & 1974 & & & \\
\hline Japão & $1.800 \mathrm{mil}$ & 1970 & & & & & \\
\hline URSS & $6.000 \mathrm{mil}$ & $\begin{array}{c}\text { de } 1945 \\
\text { a } 1952\end{array}$ & & & & & \\
\hline EUA & $2.000 \mathrm{mil}$ & 1950 & & & & & \\
\hline México & $67,4 \mathrm{mil}$ & 1980 & 116 mil & 1983 & 247 mil & 1986 & \multirow{2}{*}{$\begin{array}{l}\text { COSTA } \\
(2004)\end{array}$} \\
\hline Chile & $37,6 \mathrm{mil}$ & 1979 & $143,8 \mathrm{mil}$ & 1996 & $96 \mathrm{mil}$ & 2000 & \\
\hline \multirow[b]{2}{*}{ Brasil/FGTS } & $366,81 \mathrm{mil}$ & 1980 & & & & & \multirow{4}{*}{$\begin{array}{c}\text { CHERKE } \\
\text { ZIAN e } \\
\text { BOLAFFI } \\
(1998)\end{array}$} \\
\hline & $3.391,34 \mathrm{mil}$ & $\begin{array}{c}\text { de } 1964 \\
\text { a } 1997\end{array}$ & & & & & \\
\hline \multirow[b]{2}{*}{ Brasil/SBPE } & $260,53 \mathrm{mil}$ & 1980 & & & & & \\
\hline & $2.407,26 \mathrm{mil}$ & $\begin{array}{c}\text { de } 1964 \\
\text { a } 1997\end{array}$ & & & & & \\
\hline
\end{tabular}

Mesmo considerando as grandes diferenças entre esses países, principalmente, no que se refere às demandas e aos recursos disponíveis, e considerando o risco de uma comparação simplista, este quadro fornece alguns parâmetros para entender as dimensões da produção financiada pelo SFH. Ao observá-lo, uma das questões que ocorrem é que a atuação do Brasil, nesse campo, não foi tão expressiva, sobretudo se se considerar que aqui aconteceu um dos mais fortes movimentos migratórios do mundo e, em conseqüência, um dos mais acelerados processos de urbanização. E também ocorre que residiria aí uma das importantes causas da amplitude das estatísticas relacionadas às favelas, cortiços e outras formas de sub-habitação.

Além da questão das quantidades da produção habitacional brasileira, é importante observar que, durante o período do $\mathrm{BNH}$, essa produção não priorizou os extratos de menor renda da demanda por habitação. Aliás, priorizou os extratos de maior renda. Segundo ARRETCHE (1990, p. 31):

"[........] os subsídios foram aplicados indiscriminadamente, isto é, a todos os financiamentos habitacionais, independentemente de seu montante. Isto 
implicou que os subsídios concedidos fossem diretamente proporcionais ao montante dos empréstimos, isto é, quanto maior o montante do financiamento, maior o volume do subsídio; assim, os mutuários do SBPE seriam - do ponto de vista dos montantes absolutos - mais pesadamente subsidiados que os do FGTS. Em estimativa feita pelo Banco Mundial (1987: tabela 61), em 1985 cada mutuário de renda superior a cinco salários mínimos receberia uma média anual de 543 dólares de subsídio, ao passo que o subsídio creditício para os mutuários cuja renda era inferior a cinco salários mínimos foi estimado em 112 dólares."

Infelizmente, essas "estratégias" de distribuição de renda têm uma "estranha" capacidade de perpetuação. Segundo a Profa. Ermínia Maricato, apenas depois de 2004, por iniciativa do recém-criado Ministério das Cidades, é que os subsídios para habitação passaram a ser concentrados nas faixas de menor renda.

ARRETCHE (1990, p. 30) também aponta para outra marca das políticas do BNH que teve o dom de se perpetuar:

“[......... a opção exclusiva pela casa própria, a despeito das -sempre presentes- propostas de adoção de programas públicos de locação. Segundo os formuladores de políticas do (então) novo regime [militar], o crédito hipotecário seria também um fator de estabilidade política, isto é, os indivíduos que se tornassem sujeitos de um crédito hipotecário teriam resistências à participação em greves, devido à necessidade de fazer frente aos compromissos assumidos; de outro lado, o sentido da propriedade criaria nos indivíduos o desejo da estabilidade social e, portanto, resistências à participação em movimentos de protesto.

Para além dos possíveis impactos da provisão de casa própria no regime político [........], os mecanismos de política adotados seriam consistentes com a constituição de uma demanda efetiva para a indústria de construção civil . Com efeito, ao SFH só seria permitido o financiamento de imóveis novos, ou seja, imóveis com menos de 180 dias de "habite-se"'”.

Podem ser observados, até hoje, os efeitos dessas diretrizes para a manutenção de um conjunto de idéias relativas à habitação social, apesar de muitos esforços em sentido contrário. De um lado, por exemplo, no desejo de $22,2 \%$ dos moradores do Residencial Pq. do Gato $^{10}$, que dizem que gostariam de se mudar

${ }^{10}$ Empreendimento do Programa de Locação Social da SEHAB/COHAB/FMH, construído para atender aos moradores de uma favela que existia ao lado. 
para "uma casa própria, de pagar por algo que um dia fosse seu" (VIEIRA, 2005, p. 216). E de outro lado, nas constantes manifestações das entidades representativas da indústria da construção civil, que reclamam dos programas habitacionais que não destinam recursos à produção de unidades novas. ${ }^{11}$

Em relação ao SFH, cabe lembrar que, no seu desenho, a partir de 1971, o $\mathrm{BNH}$ passou a atuar como agente financeiro de $2^{\mathrm{a}}$ linha, que financiava as COHAB's, e essas assumiram o papel de agentes financeiros de $1^{\text {a }}$ linha, que financiavam os mutuários, e agentes promotores dos empreendimentos. Segundo SACHS (1999, p. 214-215), as COHAB's não podiam atrasar seus reembolsos ao $\mathrm{BNH}$, mesmo que seus mutuários atrasassem seus pagamentos. $\mathrm{E}$ a remuneração dessas companhias era obtida de comissões pagas pelos mutuários, relativas às operações financiadas pelo BNH. Dessa forma, não tinham como arcar com o financiamento de projetos que introduzissem alguma inovação em relação àqueles tradicionalmente financiados pelo Banco.

A extinção do BNH em 1986 e a transferência de suas atribuições para a Caixa Econômica Federal marcaram o início de um período de escassez de recursos federais para habitação e de desarticulação do sistema do qual ele havia sido o mais importante agente, que teve forte impacto na produção habitacional do país e, evidentemente, também na da COHAB-SP (MARICATO, 1997, p. 15).

Em 1994, foi criado o FMH (Fundo Municipal da Habitação), que é constituído majoritariamente por dotações do Orçamento Programa da Prefeitura do Município de São Paulo, e é gerido por um conselho. Até 2003, esse conselho era denominado do Fundo Municipal de Habitação e era constituído por 10 membros. E, a partir de 2003, foi criado o Conselho Municipal de Habitação, com atribuições relacionadas ao conjunto da política habitacional do município e não apenas à gestão dos recursos alocados no $\mathrm{FMH}$, composto por 48 conselheiros, sendo 16 indicados pela administração municipal, 16 eleitos entre indicados por entidades da sociedade civil (sindicatos de trabalhadores e patronais, conselhos profissionais,

11 Outros autores, além dos citados, discutem a influência da indústria da construção civil na formulação das políticas para habitação, alguns deles serão mencionados no Capítulo 2, e cabe também lembrar de MELO, em "Classe, Burocracia e Intermediação de Interesses na Formação da Política de Habitação" (1990, p. 75). 
universidades, ONG's, etc.) e 16 eleitos por voto direto dos eleitores da cidade, entre candidatos indicados por movimentos por moradia.

Pela Lei Municipal 11.632/94 que criou o FMH, a COHAB-SP assume a função de seu agente operador e a contar com uma nova fonte recursos, que passará a ser preponderante para as suas inversões em novos empreendimentos. Com a função de agente operador, além das atribuições de execução de novos empreendimentos e de administração dos contratos com mutuários e permissionários deles decorrentes. Recebeu também o espólio das intervenções do FUNAPS, antecessor do FMH, que havia sido administrado pela Superintendência de Habitação Popular (HABI). E, juntamente, recebeu a incumbência de concluir obras interrompidas (dentre elas os mutirões iniciados pela HABI, entre 1989 e 1992) e de regularizar e comercializar um grande número de empreendimentos financiados pelo FUNAPS.

São principais atividades da COHAB-SP:

- estudar a viabilidade e planejar empreendimentos;

- selecionar e adquirir terras, inclusive desapropriando;

- elaborar ou contratar a elaboração de projetos;

- submeter os projetos à aprovação dos órgãos de licenciamento e a agentes financeiros;

- contratar e fiscalizar a execução de obras;

- realizar trabalho social;

- comercializar as unidades habitacionais construídas;

- administrar os contratos com mutuários até a quitação;

- responder pelo acionamento de seguradoras, construtoras, projetistas, e mutuários ou condomínios, em casos da ocorrência de danos às moradias construídas; e

- e, mais recentemente, em parceria com cartórios, passou a articular a emissão e o registro de escrituras. 


\subsection{Dimensões e principais características das intervenções promovidas pela COHAB-SP}

Entre 1965, ano de sua fundação, e 2000, a COHAB-SP construiu 134.900 unidades habitacionais na Região Metropolitana de São Paulo, sendo 111.041 unidades de HIS (habitação de interesse social) no MSP, 19.533 unidades de HIS nas cidades de Carapicuíba, Guarulhos e Itapevi, e 4.326 unidades de renda média no MSP. Os 55 conjuntos de HIS construídos ocupam uma área de $22.285 .468 \mathrm{~m}^{2}$ e abrigam uma população de 655.865 pessoas, superior às de cidades como Piracicaba, Ribeirão Preto, São José dos Campos e Sorocaba.

\section{Tabela 1.2 - COHAB-SP}

Resumo de dados sobre as intervenções até 2.000

Número de unidades habitacionais

\begin{tabular}{lc}
\hline HIS no Município de São Paulo & 111.777 \\
\hline HIS em Carapicuíba, Guarulhos e Itapevi & 19.533 \\
\hline Renda média no Município de São Paulo & 4.326 \\
\hline Total & 135.636 \\
\hline
\end{tabular}

Dados sobre conjuntos de HIS

\begin{tabular}{lc}
\hline Número de conjuntos & 55 \\
\hline População & 655.885 \\
\hline Área de terreno total $(\mathrm{m} 2)$ & $22.285 .468,50$ \\
\hline Área de terreno residencial $(\mathrm{m} 2)$ & $8.345 .069,69$ \\
\hline
\end{tabular}

Fontes:

SILVA, M.G.P., 2004

Slomiansky, 2002, p. 96

Plano Municipal de Habitação, SEHAB, 2004, p.10

As áreas adquiridas pela COHAB somam, aproximadamente, 23,6 milhões $\mathrm{m}^{2}$. Esse número é maior que o apontado na tabela anterior, pois já incorpora áreas adquiridas na gestão da Prefeita Marta Suplicy, mas ainda não inclui as áreas obtidas por doação do MSP durante essa gestão.

Conforme apontado no gráfico a seguir, nos primeiros anos após sua fundação, a COHAB-SP começou a formar seu estoque de terras, adquirindo 
2.543.730 $\mathrm{m}^{2}$ na gestão do Prefeito Faria Lima. Mas efetuou as maiores aquisições entre 1976 e 1981, durante as gestões dos Prefeitos Olavo Setúbal e Reynaldo de Barros, em que incorporou ao seu patrimônio $14.492 .800 \mathrm{~m}^{2}$ de novas terras, que representam 65\% das terras que adquiriu até 2004.

A política de terras foi marcada pela aquisição de áreas predominantemente na Zona Leste da cidade (68\% do total) e de grandes glebas, que chegam a atingir 2,8 milhões de $\mathrm{m}^{2}$, no Conjunto Habitacional José Bonifácio.

COHAB-SP - Terras adquiridas para HIS

(não incluem habitação p/ renda média e edifícios p/ reforma)

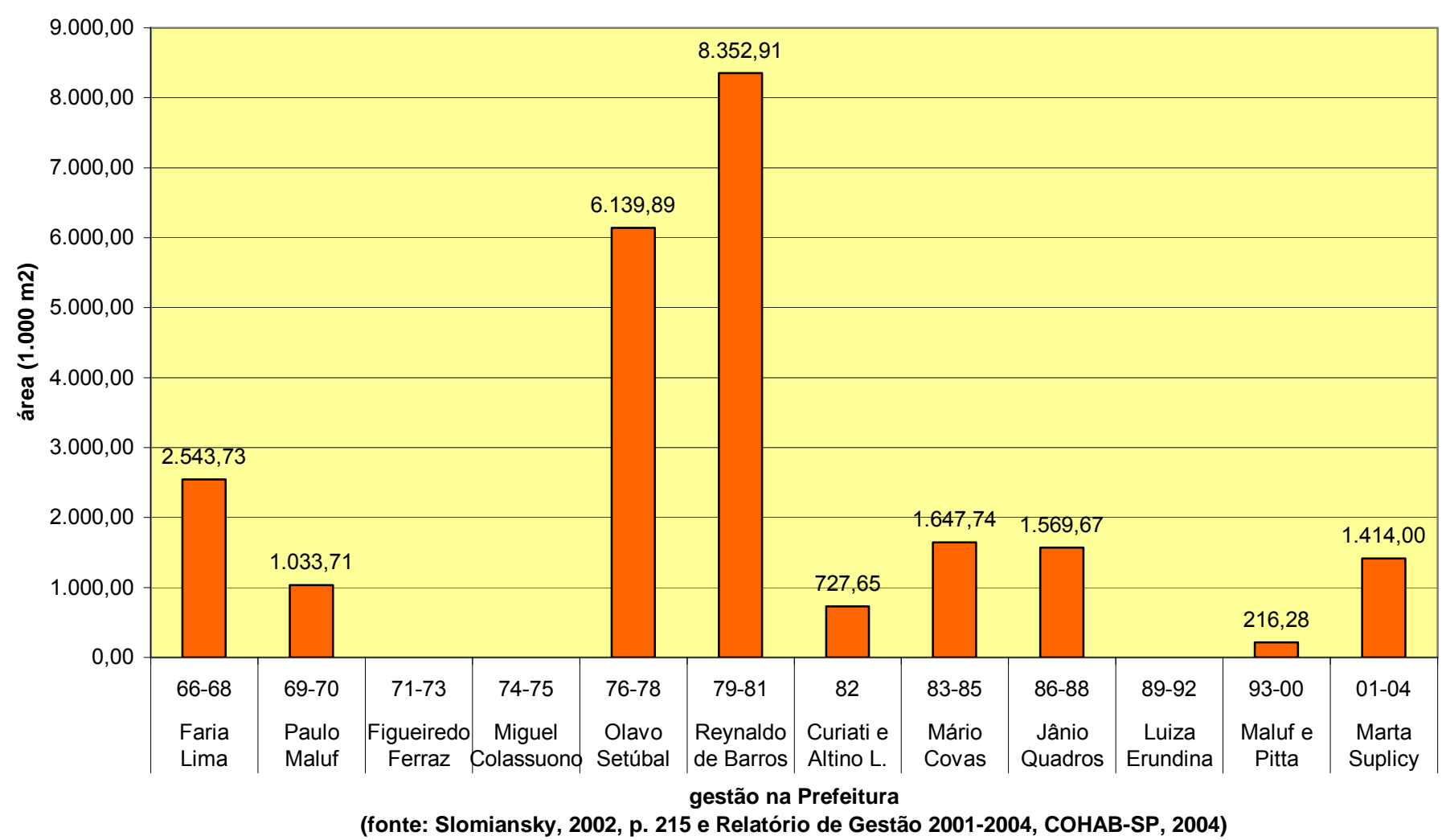

A observação do gráfico a seguir, que relaciona a quantidade de obras de HIS da COHAB iniciadas por período, indica um impulso maior na produção nos últimos anos da década de 70 (gestão Olavo Setúbal) e um pico no ritmo de início das obras no começo dos anos 80 (gestões Reynaldo de Barros, Salim Curiati e Altino Lima). 
Na gestão Mário Covas, verifica-se uma redução no início de novas obras, com uma posterior recuperação, na gestão Jânio Quadros. Nessa gestão foi contratado, em 1986, o último financiamento para obras da COHAB, concedido pela Caixa Econômica Federal com recursos do Sistema Financeiro da Habitação. Um acentuado declínio no ritmo de início de novas obras ocorre a partir da gestão Luiza Erundina, afetada pela dificuldade de obtenção de novos financiamentos (SILVA, M. G. P., 2004, p. 28).

COHAB-SP - Obras de HIS iniciadas até 2000

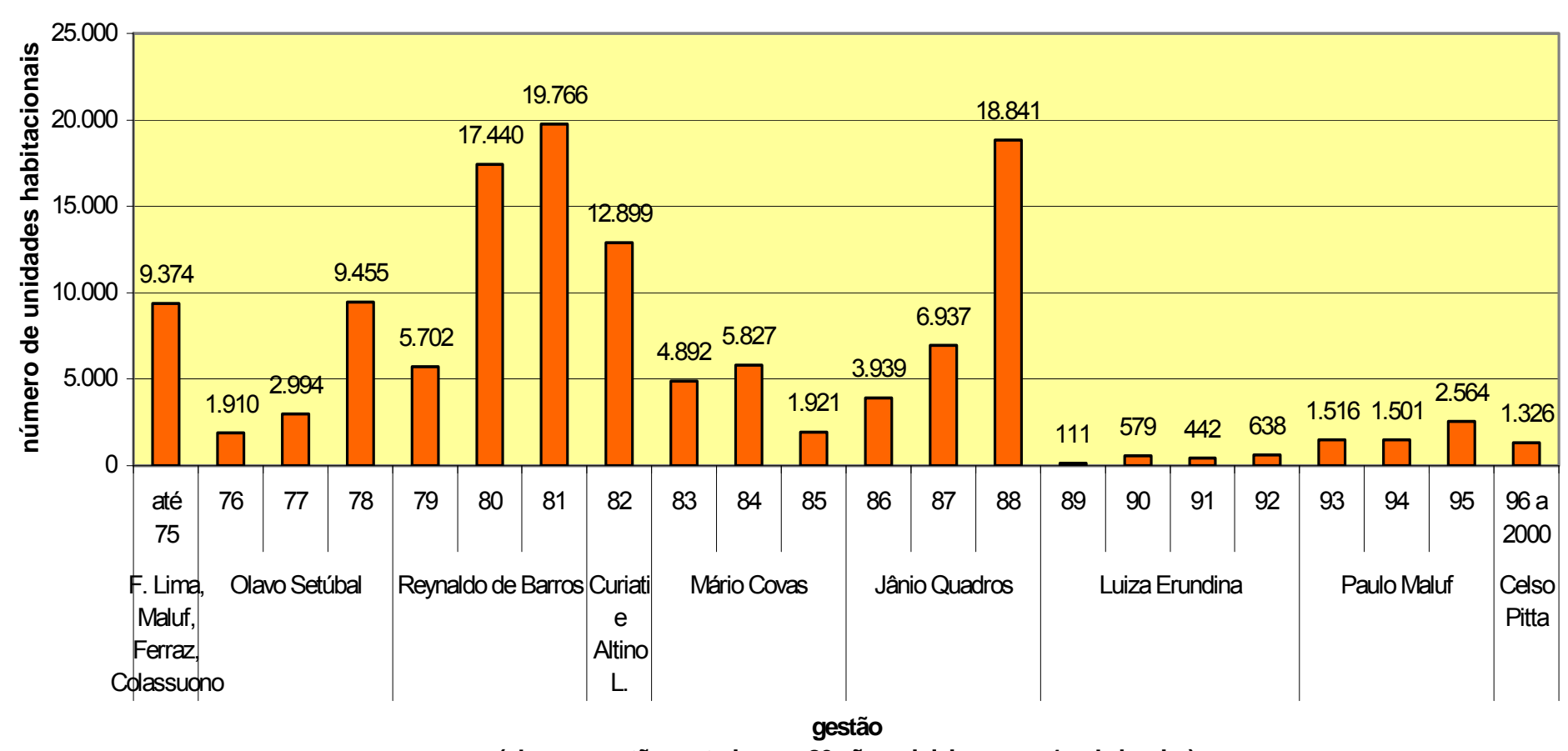

(obs.: as gestões anteriores a 86 não se iniciaram em 10. de janeiro)

(fonte: Slomiansky, 2002, p. 215)

O gráfico a seguir mostra o ritmo da conclusão das obras de HIS e, nesse caso, também de renda média. Verifica-se que os períodos em que ocorreram a conclusão do maior número de unidades habitacionais são, por ordem decrescente, os das gestões Reynaldo de Barros, Luiza Erundina e Mário Covas. Essas duas últimas gestões, se por um lado não apresentaram números comparativamente relevantes quanto ao início de obras, apresentaram números dos mais relevantes quanto à conclusão. Evidentemente, que esse fato está relacionado aos tempos 
consumidos com a execução das obras e ao forte ritmo de início de empreendimentos nos períodos precedentes.

COHAB-SP - Obras (HIS e renda média) concluídas por período

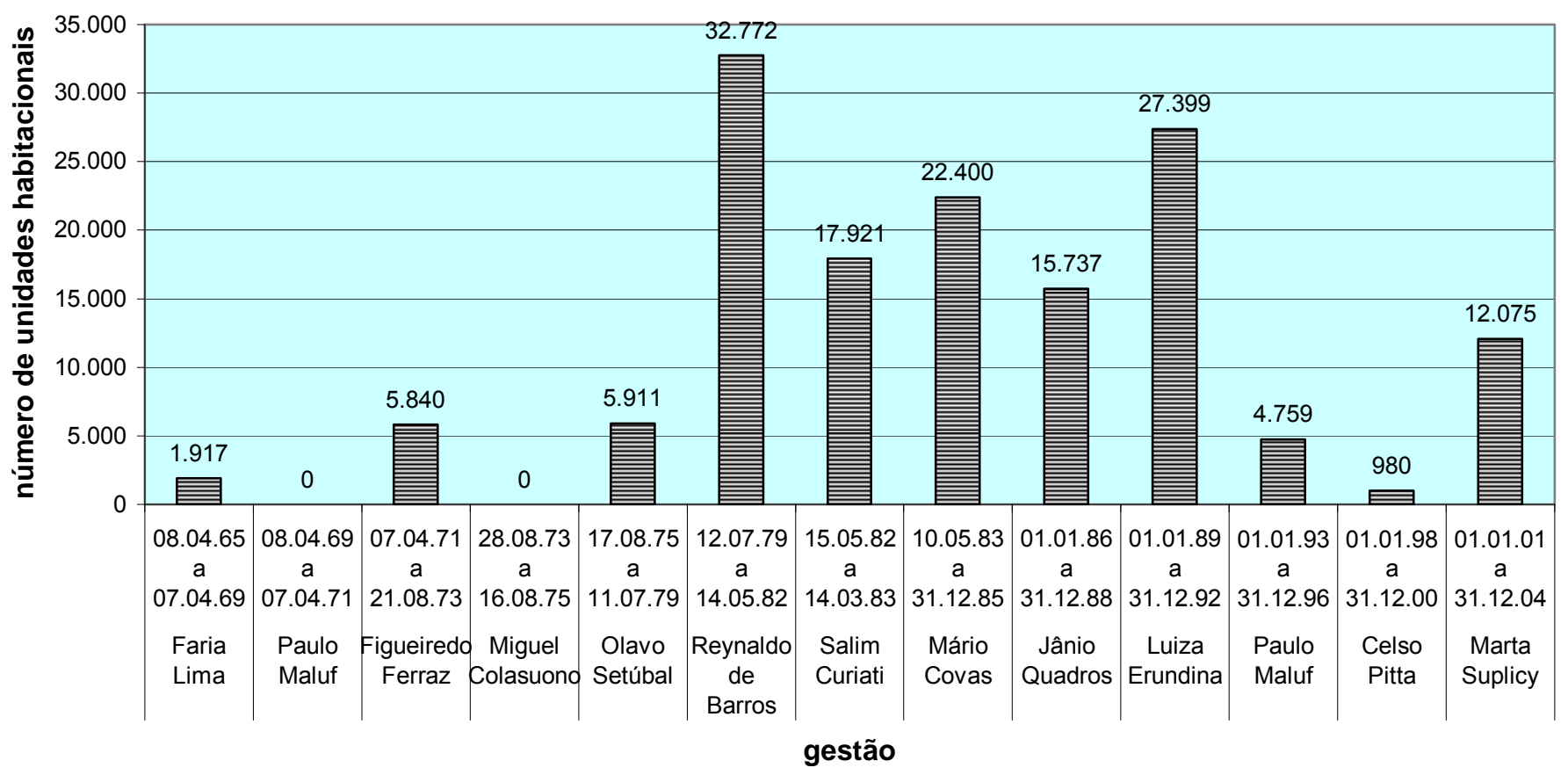

(fontes: Silva, M. G. P., 2004, p. 29

Relatório de Gestão 2001-2004, COHAB-SP, 2004, p. 5-7

Balanço Qualitativo de Gestão 2001-2004, SEHAB, 2004, p. 87-88)

Comentando a produção da COHAB-SP, entre 1966 e 1985, SACHS (1999, p. 22), diz que a produção dessa companhia foi "pouco significativa em relação ao crescimento demográfico da região metropolitana de São Paulo, cuja população passou, entre 1960 e 1985, de 4,8 para 15,1 milhões de habitantes". 
No. UH's iniciadas e concluídas por gestão

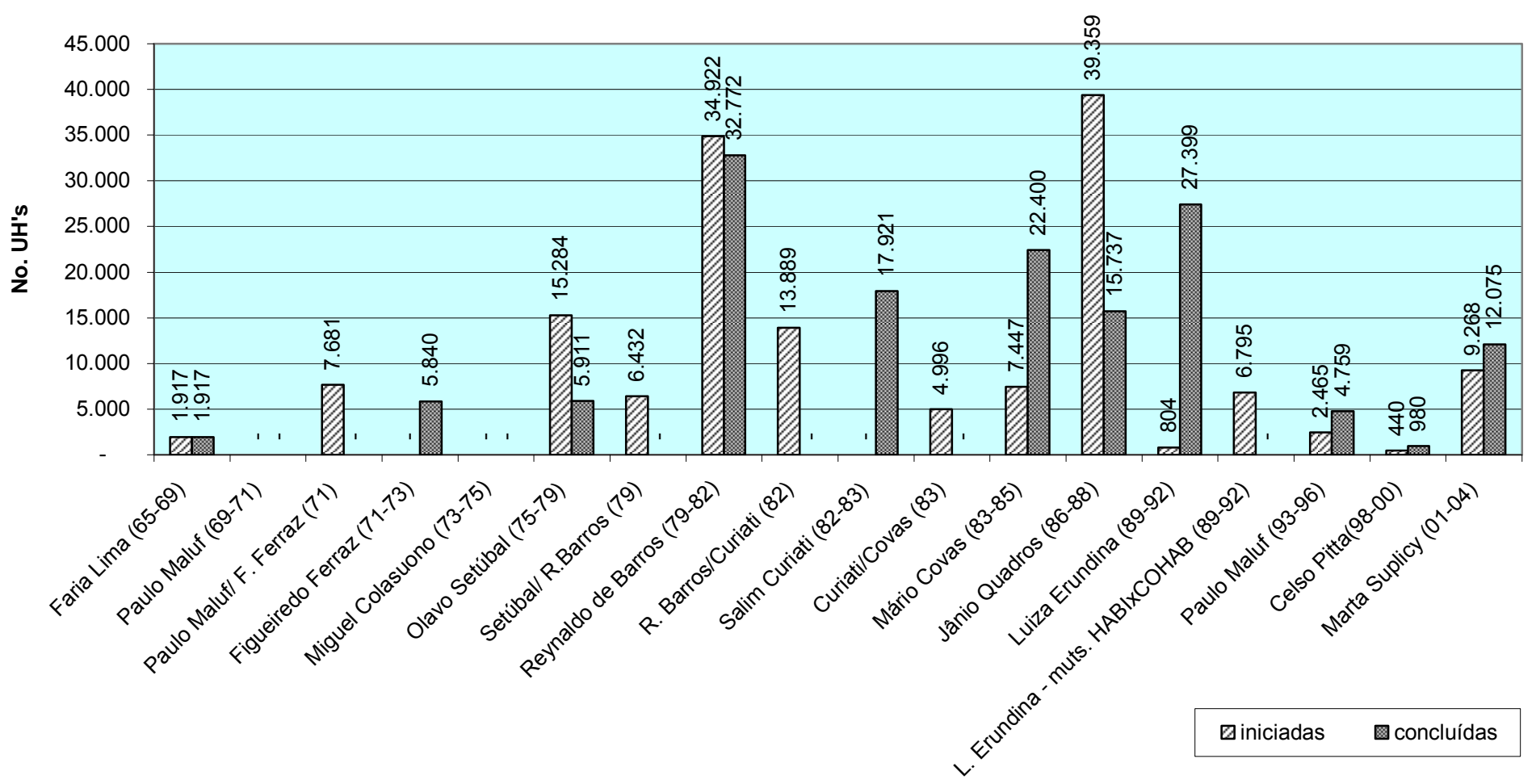

Gestão 


\subsection{A atuação de HABI e o FUNAPS}

O primeiro órgão do MSP (Município de São Paulo) criado com atribuições de atendimento habitacional foi o Serviço de Habitação Popular (SHP), que compunha a estrutura da Divisão de Serviço Social, vinculada ao Gabinete do Prefeito de São Paulo. O SHP existiu de 1955 a 1966 e a ele estiveram relacionados trabalhos como os desenvolvidos pelo MUD (Movimento Universitário de Desfavelamento).

Em 1966, foi criado HABI, Departamento de Habitação e Trabalho. Esse órgão existe até hoje, apesar de ter passado por várias transformações, recebido atribuições, status (departamento, supervisão, superintendência) e denominações diferentes, tendo readquirido a sigla de sua fundação (HABI) a partir de junho de 1986. Esteve subordinado a vários outros órgãos da administração municipal:

- SEBES - Secretaria do Bem Estar Social -, de março de 1966 a junho de 1975;

- COHAB-SP - Companhia Metropolitana de Habitação -, de junho de 1975 a abril de 1976;

- COBES - Coordenadoria do Bem Estar Social, que substituiu a SEBES, a partir de fevereiro de 1977, e era subordinada à Secretaria das Administrações Regionais -, de abril de 1976 a junho de 1982;

- FABES - Secretaria da Família e Bem Estar Social, que substituiu a COBES -, de junho de 1982 a janeiro de 1986;

- SEHAB - Secretaria da Habitação e Desenvolvimento Urbano -, de janeiro de 1986 até hoje.

A história de $\mathrm{HABI}$ pode ser dividida por períodos, caracterizados pela predominância de determinadas formas de atuação.

De 1966 a 1970, HABI atuou primordialmente no atendimento a famílias residentes em favelas, em alguns momentos priorizando a desocupação de áreas destinadas a obras públicas, e utilizou principalmente as seguintes formas de atendimento: compra de casas em conjuntos da COHAB; compra de terrenos e construção de casas; construção de casas em terrenos próprios; aluguel de casas ou quartos; e fornecimento de recursos para retorno ao local de origem. 
De 1971 a 1975, HABI buscou definir melhor linhas de ação, a partir de um diagnóstico dos problemas habitacionais do município, tendo realizado, nesse período, o primeiro cadastro de favelas (1973) e a pesquisa amostral sobre cortiços (1975). No entanto, muitas das ações pretendidas não deixaram a condição de propostas. Dentre elas, a instituição do Sistema Municipal de Habitação (incluindo as Vilas de Habitação Provisória) e o Programa Municipal de Habitação de Interesse Social. Entre os trabalhos que se efetivaram estão: remoção de famílias moradoras em favelas em situação de emergência e também em favelas localizadas em terrenos destinados a obras públicas; e construção de 41 casas em regime de mutirão (PMSP/SEHAB/HABI, 1992, cap. III).

Em 27/04/1979, a Lei nº 8906 criou o Fundo de Atendimento à População Moradora em Habitação Subnormal -FUNAPS-, "com o objetivo de prover habitações ou melhorar as condições de habitabilidade do segmento da população mais pobre, a fundo perdido. Este fato significou uma mudança na atitude do poder público municipal no trato do problema habitacional da população de baixa renda, e um maior empenho em garantir recursos para este atendimento." (AVRITSCHER, 1995)

Entre 1979 e 1982, o atendimento habitacional passou por mudanças significativas em relação ao anteriormente adotado, sendo orientado pelas seguintes diretrizes básicas:

- Fornecer condições de fixação da população no local de moradia,

- Priorizar a provisão de habitação como solução efetiva da problemática habitacional,

- Desenvolver programas de melhorias de condições de habitabilidade em favela,

- Priorizar o atendimento coletivo no uso do FUNAPS,

- Criar condições de participação da população nas soluções habitacionais.

Para a implementação das ações foram passadas atribuições importantes da administração direta para a indireta, como a execução dos programas PROMORAR e PROFAVELA. O PROFAVELA, desenvolvido pela EMURB, visava dotar favelas de infra-estrutura urbana, unidades habitacionais e equipamentos urbanos, com recursos do FUNAPS. E o PROMORAR -Programa de Erradicação da 
Sub-Habitação-, desenvolvido pela COHAB e pela EMURB, com recursos do SFH, consistiu na construção de embriões para população de renda compatível com os moradores de favela.

Apesar deste último prever a permanência das favelas no próprio local, a ênfase era a remoção da população em função das obras públicas, com destino desta para unidades do PROMORAR. As obras foram implementadas pela EMURB e a SEBES perdeu o controle do programa.

Em 1979, por pressão de mobilização dos movimentos de moradia do município, foram assinados convênios entre a prefeitura e as concessionárias estaduais de eletricidade e saneamento, para fornecimento de eletricidade e água às favelas. A ELETROPAULO, num primeiro momento, eletrificou as áreas municipais e a partir de 1982, as áreas particulares, por pressão da ampla mobilização dos favelados moradores em terrenos particulares. Já a SABESP teve uma postura mais tímida. Isto se deveu à falta de tecnologia apropriada para implantar o sistema de abastecimento de águas nas favelas. Com o advento do PAD (tubulação flexível), os problemas foram superados e a concessionária passou a implantar redes de água em todas as favelas. A PMSP cuidava de intermediar os contatos entre a população favelada e a SABESP e de organizar a demanda, uma vez que as ligações eram coletivas. Esse fato auxiliou na organização das favelas do município.

Em junho de 1982, a COBES foi substituída por FABES -Secretaria da Família e Bem Estar Social-, adquirindo maior autonomia. Em maio de 1983, foi elaborado um plano habitacional intersecretarial para o município, congregando FABES, SEHAB e SEMPLA -Secretaria Municipal do Planejamento. Houve uma inflexão na postura institucional onde a atuação do poder público passou a ser subordinada a diretrizes de uma política habitacional, e as favelas passaram a ser tratadas nesse âmbito, com diretrizes claras para a sua reurbanização e regularização fundiária.

Em decorrência desse plano, a linha de atuação da FABES na área habitacional foi ampliada e as mudanças mais importantes foram:

- Regularização jurídica da posse da terra para permitir a urbanização de favelas como provisão habitacional. 
- Utilização do FUNAPS como mecanismo de financiamento subsidiado, possibilitando o retorno e a utilização de parte dos recursos despendidos.

- Aquisição de glebas com financiamento direto para a população, permitindo programas de provisão de habitação para atendimento coletivo.

- Experiências piloto de atuação em cortiço.

Os programas habitacionais tiveram um caráter mais democrático: houve participação da população na execução dos projetos e obras, e a institucionalização da auto-construção com recursos municipais. Foram desenvolvidos três programas específicos para as favelas com recursos do FUNAPS: urbanização de favelas, provisão de habitação e recuperação de favelas. Houve apenas a desafetação de uma favela.

FABES foi extinta por meio do Decreto Municipal $n^{\circ} 021841$ de 03/01/1986 e em 15/01/86 o Decreto n 21862 transferiu seu departamento SATHS Supervisão de Atendimento à População Moradora em Habitação Subnormal para a SEHAB juntamente com o FUNAPS.

Em 09/06/1986, o Dec. n. ${ }^{\circ} 22.284$ transformou SATHS em HABI Superintendência de Habitação Popular. Em 17/12/1986 a Lei $n^{\circ} 10237$, que reestruturou $\mathrm{HABI}$, estabeleceu que sua área de atuação seria habitação de interesse social.

A transferência de $\mathrm{HABI}$ para SEHAB, órgão normativo de assuntos habitacionais mais amplos, acarretou uma mudança no enfoque dado à questão habitacional de interesse social, que, de predominantemente assistencial, passou a focar, com mais ênfase, a produção de habitação e melhoria das condições de habitabilidade.

Neste período, intensificou-se o processo construtivo por empreiteiras, iniciado na gestão Covas, diminuindo a incidência do processo de auto-construção, que havia sido utilizado em maior escala até o momento. 
A atuação de $\mathrm{HABI}$ se concentrou na urbanização de favelas, melhorias em favelas e provisão de terra e moradia. Foram desafetadas sete áreas de uso comum do povo, ocupadas por favelas e autorizada sua concessão de direito real de uso aos moradores. Também foi realizado, de forma sistemática, o segundo cadastro em favelas.

Por outro lado, o desfavelamento, executado no período entre 1986 e 1988, voltou a ser priorizado e foi executado pela Secretaria de Negócios Extraordinários, com recursos orçamentários alocados na SEHAB e repassados para o FUNAPS para aquisição de casas da COHAB para os moradores removidos. Entretanto, no final da administração apenas três favelas foram removidas.

Neste governo a CMSP aprovou a Lei de Desfavelamento ou Lei de Operações Interligadas, que permite ao poder público vender o direito de construir além daquele permitido pelo zoneamento municipal, a empreendedores imobiliários, em troca da produção de moradias para os moradores de favelas. Esta lei não significou uma política de desfavelamento pois as habitações produzidas foram repassadas para HABI para remoção de população de áreas de risco e para execução de obras públicas.

Em 1989 foi eleita a prefeita Luiza Erundina com grande apoio popular, principalmente dos movimentos de moradia.

A nova política em favelas do município desenvolvida nessa gestão foi influenciada fortemente pelo comprometimento da prefeita com o setor de habitação e com a participação dos movimentos de moradia. Pela primeira vez na história da prefeitura de São Paulo a urbanização de favelas passou a fazer parte da agenda municipal integrada à política habitacional.

Houve um compromisso do aparelho estatal para que essa política se efetivasse, que se refletiu num novo desenho institucional ampliado e decentralizado e num grande aumento de seus quadros.

A política habitacional, em especial, foi voltada para a população de baixa renda, incluindo os movimentos de moradia e as favelas. Foi um marco na história 
da PMS, pois as transformações foram muito significativas em relação aos governos municipais anteriores.

A prioridade dada pelo governo a essa política, se refletiu também no crescimento significativo do orçamento destinado ao setor somado aos recursos provenientes da iniciativa privada através das operações interligadas. Pela primeira vez na história do município a área de habitação pode dispor de uma quantidade de recursos tão grande.

Segundo o Relatório de Gestão 1989-1992: Balanço da Atuação de HABI, executado em 1992, a Política Habitacional realizada por HABI foi baseada nos seguintes pressupostos:

a. "Direito à moradia e à cidade, reconhecendo a existência da cidade real (dos assentamentos precários como favelas, loteamentos irregulares, cortiços e coabitações);

b. Direito à arquitetura ( e engenharia ) e respeito ao meio ambiente;

c. Direito à cidadania e participação popular na formação e implementação de Programas e Projetos e estímulo à auto-gestão;

d. Redução de custos sem perda da qualidade, administração ágil e eficiente".

Tais diretrizes se converteram em dois grandes eixos da política habitacional:

1)Provisão de terra e moradia;

2) Ação em Favelas, permitindo identificar especificidades nos conteúdos, programática diversa e nos pilares dessa atuação: com trabalho social, participação popular e assistência ao munícipe.

Desdobra-se, assim, uma estrutura programática:

1) Provisão de Moradias: por empreiteira, mutirão com autogestão, intervenção em cortiço.

2) Ação em Favelas: urbanização, remoção /alojamento /emergência, melhorias, regularização fundiária. 

3) Convênios Jurídicos
4) Trabalho Social
5) Comercialização: contratos financeiros."

Em março de 1990 o Executivo enviou à Câmara Municipal o projeto de lei para desafetação de 139 áreas municipais de uso comum abrangendo 36000 famílias, propondo a concessão de direito real de uso gratuita por 90 anos.

Em 1994, no governo Paulo Maluf, o FUNAPS foi extinto e foi votado na Câmara dos Vereadores o novo FUNDO MUNICIPAL DE HABITAÇÃO, vinculado à COHAB.

Projeto Cingapura corresponde à denominação amplamente divulgada e conhecida do Projeto de Urbanização de Favelas com Verticalização - PROVER, o programa de maior visibilidade e que sintetizou a política habitacional da gestão do ex-prefeito Paulo Maluf, no período de 1993-1996, com continuidade na gestão do ex-prefeito Celso Pitta e em conclusão na gestão da prefeita Marta Suplicy, sob a denominação PROVER.

A política de favelas da gestão Paulo Maluf partiu de uma concepção totalmente distinta das abordagens anteriores, baseada na manutenção da população favelada nas áreas já ocupadas, procurando atendê-la integralmente, quando possível, porém, desmontando a ocupação e o tecido social anteriormente existente, alterando completamente as condições locais das áreas de intervenção.

Esse programa apresentou como solução para as áreas ocupadas, a implantação de novos conjuntos habitacionais, prevendo na maioria dos casos, um projeto integralmente novo de implantação de novas edificações e provisão de infraestrutura para as áreas, com abertura de novos viários, promovendo grandes operações de engenharia nas áreas, movimentos de terra, desvios de cursos d'água para viabilizar implantação de conjuntos e contenções geotécnicas. Priorizou ao máximo a verticalização, embora também tenha ocorrido, numa escala muito menor, a construção de embriões e alguns casos de urbanização de parte da favela, com a manutenção das características pré-existentes da ocupação. 
Com a verticalização processada no próprio local onde se situava a favela, o que se pretendeu foi a substituição da favela por um conjunto habitacional de interesse social.

O Projeto Cingapura teve o objetivo claro de erradicar as favelas nos vários locais onde ocorreram às intervenções, inclusive a sua forma urbana e tecido social pré-existentes, sem que as famílias estivessem realmente preparadas para a transição que implicava em incremento de taxas e convívio condominial, na medida em que a nova solução era repentinamente apresentada e não havia outras escolhas: ou era o conjunto Cingapura, ou era o conjunto Cingapura.

As três primeiras Fases foram executadas com recursos do orçamento municipal. A Fase IV contou com recursos oriundos do contrato de financiamento assinado com o BID. 


\section{Capítulo 2:}

\section{As críticas mais freqüentes ao antigo modelo COHAB}

A atuação da COHAB-SP, por quase toda a sua existência, tem sido objeto de muitas críticas e poucos elogios. Críticas pela baixa qualidade dos conjuntos habitacionais que produziu,; pela sua precária inserção urbana, resultante das grandes distâncias aos principais pólos de oferta de trabalho, e da insuficiência dos equipamentos e serviços públicos e comunitários disponíveis.

Críticas também pela inadequação dos valores de financiamento e dos custos de manutenção dos condomínios à capacidade de pagamento dos mutuários e permissionários (pessoas que firmam contrato de permissão de uso, que são distintos dos contratos de compra e venda firmados com os mutuários); e pela alta dependência ao Orçamento Programa do Município de São Paulo. Dependência que, em grande medida, decorre da alta inadimplência verificada no retorno dos financiamentos aos mutuários, que exige maiores aportes de recursos pela Prefeitura do Município de S. Paulo, necessários para que sejam pagas as parcelas das dívidas da Companhia, contraídas com o Sistema Financeiro da Habitação. Críticas, também, pelo grande número de unidades habitacionais e áreas livres de seu patrimônio ocupadas irregularmente.

E as críticas continuam sobre o que seria uma falta de agilidade para responder às necessidades de produção em grande escala, de implementação de programas e projetos diversificados, e pela morosidade dos processos de regularização fundiária de conjuntos já entregues aos moradores.

A COHAB-SP é apontada como um órgão que gastaria muito e produziria conjuntos habitacionais de baixa qualidade. $E$ teria, também, uma grande inércia que dificultaria mudanças de rumo, sendo essa apontada como uma das razões para que os novos programas introduzidos na gestão da Prefeita Luiza Erundina (mutirões com autogestão, urbanização de favelas, etc.), entre 1989 e 1992, fossem levados para a Superintendência de Habitação Popular (HABI), da Secretaria da Habitação e Desenvolvimento Urbano (MARICATO, 1997, p. 49). 
Tendo urbanizado áreas que totalizam, aproximadamente, 22,3 milhões de m2 e construído cerca de 135 mil moradias até a gestão Pitta (SLOMIANSKY, 2002, p. 96), a atuação da COHAB-SP marcou profundamente a paisagem da cidade. Essa marca fica mais evidente pelo predomínio das intervenções em grandes glebas - atingem 2,8 milhões m2, no $\mathrm{CH}$ José Bonifácio - e pela grande concentração na Zona Leste da cidade, onde estão localizadas $68 \%$ das unidades construídas. Também fora do MSP, em Itapevi e Carapicuíba, foi muito grande o impacto da implantação dos conjuntos da COHAB-SP, pois abrigam populações que representam, respectivamente, 17,6\% e 21,9\% das populações desses municípios (SLOMIANSKY, 2002).

\subsection{Política de aquisição de terras - a expansão para os extremos da cidade}

Por muito tempo, prevaleceu na COHAB-SP uma política de aquisição de terras em zona rural ou na extrema periferia da zona urbana, em áreas muito distantes dos locais de maior oferta de trabalho, áreas não dotadas, à época, de infra-estrutura e de serviços públicos, e muitas com solos frágeis e com outras características que apontavam para a necessidade de serem preservadas por razões ambientais. Para Helena Menna Barreto Silva (SILVA, 1997, p. 149 e 150), essas seriam as características predominantes nos terrenos adquiridos entre $1965 \mathrm{e}$ 1982, que representariam por volta de $85 \%$ do total das aquisições da Companhia. Segundo essa mesma autora:

- a COHAB teria se contentado em "trabalhar nas condições de mercado fundiário, utilizando áreas desvalorizadas e contribuindo para a valorização de terrenos vizinhos, contribuindo desse modo para encarecer os lotes populares. Nem políticas federais nem municipais buscaram soluções para obter terrenos adequados para os conjuntos COHAB ou para viabilizar empreendimentos"

- "a seleção de terrenos e os projetos da COHAB/SP - na sua grande maioria - são bem característicos de uma política habitacional completamente desligada da gestão urbana. Nem a companhia se preocupava com o que 
acontecia na cidade e no entorno de seus conjuntos, nem os órgãos de planejamento tratavam da integração desses conjuntos na cidade, salvo algumas iniciativas isoladas que não chegaram a sair do papel" (SILVA, 1997, p. 84, 85 e 162).

De acordo com a análise feita no Plano Municipal da Habitação (PMSP/SEHAB, 2004, p. 9), na escolha dos terrenos, teria sido preponderante a necessidade de buscar áreas de menor preço, de forma a reduzir os custos finais da moradia e adequar os valores dos financiamentos à capacidade de pagamento das famílias, numa situação em que a política habitacional não previa subsídios.

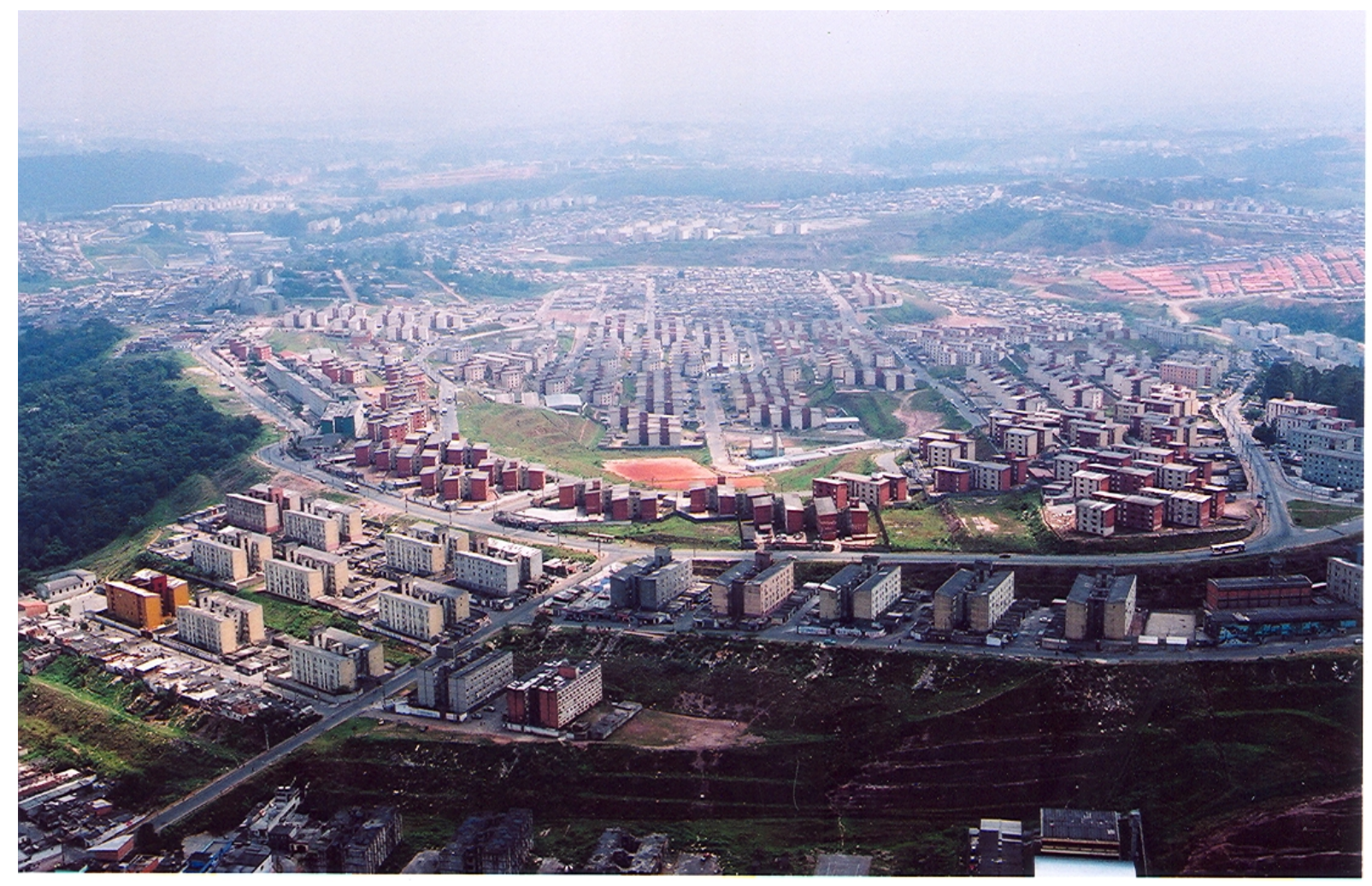

Conjunto Habitacional Santa Etelvina (Arquivo COHAB-SP)

Helena M. B. Silva (SILVA, 1997, p. 164) questiona a efetividade da economia obtida com a aquisição de terrenos nos extremos da periferia. Afirma que não se conhecem estudos de viabilidade que tivessem orientado as decisões de se adquirir tais áreas, e que o preço dessas terras, somado ao preço das obras necessárias para viabilizar a sua ocupação, superaria o preço de terras melhor localizadas, que recebessem projetos mais cuidadosos e preocupados com a economia nas obras. E cita estudo realizado pelo Eng. José Luís Bessa que 
apontaria que um lote produzido pela COHAB em S. Etelvina teria atingido o valor de 7,4 VRF/m2, totalizando-se todos os valores necessários para essa produção, e que terreno na região de São Miguel Paulista, já dotado de infra-estrutura, poderia ser adquirido a $2 \mathrm{VRF} / \mathrm{m} 2$.

Para Lizete Rubano (RUBANO, 2001, p. 59), havia também um "discurso oficial" que justificava a "ocupação das periferias como medida urbana significativa". E exemplifica com o depoimento à revista Construção ( $n^{\circ} 1415,1975$, p. 10), do então presidente da COHAB-SP, Francisco Queluz, para quem "a execução do Conjunto de Itaquera (....), revelaria também a capacidade da COHAB de recuperar manchas urbanas deterioradas da periferia de São Paulo, através da implantação de grandes conjuntos dotados de todos os serviços necessários".

O próprio Plano Diretor de 1985 continha uma forte crítica à política de aquisição de terras da COHAB: "A socialização desses custos oculta o fato de que houve um grande erro na escolha dessas localizações extremamente periféricas, em vez de optar pelo preenchimento, com conjuntos menores, dos vazios urbanos no anel intermediário e nas partes mais próximas do anel periférico" (PLANO DIRETOR, 1985, p. 33; apud SACHS, 1999, p. 220).

Ermínia Maricato, abordando, de forma geral, a questão da localização dos conjuntos implantados pelos agentes promotores do $\mathrm{SFH}$, menciona aspectos que também são evidentes nas intervenções da COHAB-SP:

“... as falhas de localização dos conjuntos e de ausência de planejamento urbano adequado, talvez tenham acarretado mais prejuízo para o interesse público, de um modo geral. O impacto sobre o mercado fundiário acarretando vetores de crescimento inadequados para as cidades, a segregação ou isolamento dos moradores que propicia, inclusive, o aumento da violência, o custo da implantação da infra-estrutura que acaba por encarecer todo o mercado do lote popular, os danos ao meio ambiente, são aspectos observáveis em todo país (Londrina, Aracajú, Natal, Salvador, Belém) com trágicas conseqüências sociais, econômicas e ambientais." (MARICATO, 1997, p. 51).

Um importante indicador da violência mencionada aponta que, na Cidade Tiradentes, $16,44 \%$ das mortes são causadas por homicídio, contra $8,4 \%$ no Município de São Paulo (SLOMIANSKY, 2002, p. 134). Os conjuntos da Cidade 
Tiradentes estão entre os maiores exemplos da precariedade dos conjuntos da COHAB-SP, reúnem 42.379 unidades habitacionais, 211.895 habitantes e se situam a $40 \mathrm{~km}$ do Centro.

\subsection{Projetos - a padronização excessiva}

Se, como relatado, grande parte dos terrenos adquiridos era inadequada, um olhar sobre os conjuntos construídos pela COHAB-SP até 2001 faz com que se lamente também pela qualidade da maioria dos projetos, pela oportunidade perdida de se ter produzido melhores espaços tanto para a população diretamente envolvida, quanto para as cidades em que foram implantados.

NOGUEIRA (2003, p. 5), mesmo considerando que a construção de conjuntos habitacionais pode ter "representado uma melhoria na qualidade de vida para aqueles que antes viviam no cortiço ou na favela", pergunta se esses conjuntos, "como obras do Estado, não poderiam ter atingido melhor qualidade, (......) não poderiam ter contribuído para enriquecer o ambiente construído dos bairros em que se situam?".

Características que, segundo COMAS (1986), são típicas dos conjuntos do BNH também são típicas dos antigos conjuntos da COHAB-SP. Características como, descuido com a delimitação de espaços públicos, semi-públicos e privados; espaços vazios com características de "terra de ninguém", "dificuldades de orientação que se podem creditar, em primeira instância, à repetitividade de blocos iguais em grande escala e à ausência de diferenciação clara e consistente de suas entradas, legíveis desde ruas e caminhos do conjunto".

Afirmação semelhante é feita por Lizete RUBANO (2001, p. 60):

- "Blocos repetitivos de apartamentos de 4 pavimentos" (depois se disseminariam os prédios de 5 pavimentos), "com unidades nos térreos: as Portas de ingresso não guardam relação precisa com as ruas internas ao conjunto, dificultando a orientação;

- Os espaços entre edificações são coletivos e, em geral, ou não recebem tratamento algum ou são inviáveis pela topografia. As possibilidades de uso efetivo destes espaços são limitadas ou nulas;

- Não há privacidade nos apartamentos térreos que se defrontam com essas 
áreas;

- A monofuncionalidade estabelecida pelas regras do SFH (não era financiado edifício de uso misto, por exemplo), comprometeu por muitos anos o grau de urbanidade dos Conjuntos que, só com o passar dos anos começaram a ter serviços e comércios em quantidade - e localização - satisfatórias ao número de moradores (muitos por conta deles mesmos, com o implemento das atividades informais);

- Há trechos de casas unifamiliares isoladas ou geminadas nos lotes (com dimensões entre 160 e 240 m2), conformando quarteirões estreitos e compridos e uma área construída demarcada pela repetitividade dos telhados de fibrocimento."

Parece que não seria injusto dizer que boa parte dos conjuntos que a COHAB-SP construiu até 2001 têm feições daquilo que HUET (1986/1987) chama de "jungles urbanas":

"espaços disformes e opacos, sem nenhum simbolismo, desprovidos de explícitas referências de qualquer convenção de sociabilidade" e que, portanto, produzem "formas novas de barbarismos dotados de ritos e mitos próprios, nos quais a sociedade nega a se reconhecer".

Para SLOMIANSKY (2002, p. 102):

"Os fragmentos urbanos hoje ocupados por conjuntos habitacionais de interesse social construídos pela COHAB-SP apresentam, além de baixa densidade populacional, outros problemas decorrentes do uso de soluções padronizadas. Entre as surgidas da presente análise, destacamos a ruptura com a escala do entorno de implantação, o traçado de sistemas viários complexos, a existência de porções consideráveis de áreas designadas verdes de difícil acesso e aproveitamento por parte da população, grandes extensões de áreas desmatadas e enormes volumes de obras de terraplanagem para a adaptação dos projetos, elevadas porcentagens de áreas previstas para adensamentos áreas remanescentes - ainda vazias ou, como se verá, freqüentemente ocupadas com assentamentos precários e ilegais."

Sobre as soluções padronizadas que, segundo a autora, estariam na origem desses problemas, SLOMIANSKY (2002, p. 102), diz:

"A prática do uso do "projeto-padrão" fica evidente pela adoção de soluções semelhantes nos projetos dos conjuntos habitacionais implantados em glebas de 
dimensões, características geomorfológicas e topográficas diferentes, localizados tanto em áreas urbanizadas quanto em áreas de transição urbano/rural e de programas edificatórios diversificados. Essa prática se manifesta também na ausência sistemática de partidos urbanísticos, ou seja, de uma proposta urbana abrangente, de um intenção que transcenda a simples e aleatória distribuição de parcelas sobre o território municipal.

Assim instaura-se na COHAB uma visão isolada de cada projeto de conjunto desligado de seu entorno de implantação, mera sobreposição de partes que não conseguem integrar um todo e em que apenas se distingue uma certa conexão um vínculo geralmente associado ao uso comum das vias de circulação principal.

As implicações dessa prática projetual se agravam se considerarmos que grande parte das glebas adquiridas pela COHAB-SP exigiam soluções urbanísticas complexas e abrangentes, por localizar-se geralmente em áreas pouco povoadas e carentes de infra-estrutura, e por apresentar condições físicas desfavoráveis ou impedimentos legais (declives íngremes, córregos, faixas "non aedificandi", áreas de preservação, faixas de servidão)".

Para Helena Menna Barreto SILVA (1997, p. 162):

"dado o porte de algumas glebas, ou agrupamento de glebas contíguas, elas exigiam planos urbanísticos complexos, ainda que os projetos fossem executados em etapas. As grandes glebas da zona de expansão urbana encontravam-se sobre solos frágeis e de declividade acentuada, exigindo projeto cuidadoso para sua ocupação, o que é o contrário do que foi feito. Os projetos da COHAB/SP foram desenvolvidos sem avaliação geotécnica e nem mesmo pedido de diretrizes aos organismos municipais."

O pouco cuidado com os projetos resultou também em grandes e desatrosas intervenções na morfologia dos terrenos, através de serviços de terraplanagem de grande porte. Nas glebas de Santa Etelvina, foram movimentados $12 \mathrm{~m}^{3}$ de terra para cada $\mathrm{m}^{2}$ de superfície, segundo o "Dossiê: A Verdade Sobre a COHAB" (COHAB-SP, 1989, p: 16), que usa o termo "terra arrasada" para caracterizar essa forma de fazer terraplanagem. Em muitos casos, esses serviços de terraplanagem removeram solos argilosos mais resistentes à erosão e deixaram expostos à ação das chuvas, solos de alteração de rocha muito suscetíveis ao carreamento pelas águas. $\mathrm{O}$ descuido com o projeto combinou-se com a forma de 
executar a obra, que deixava a implantação dos sistemas de drenagem e a pavimentação para depois do término da construção das edificações e, nesse intervalo (às vezes, muito longo em razão de dificuldades para a obtenção de financiamento), os solos ficavam sujeitos à erosão, o que redundava em assoreamentos de córregos e inundações, dentro e fora das glebas.

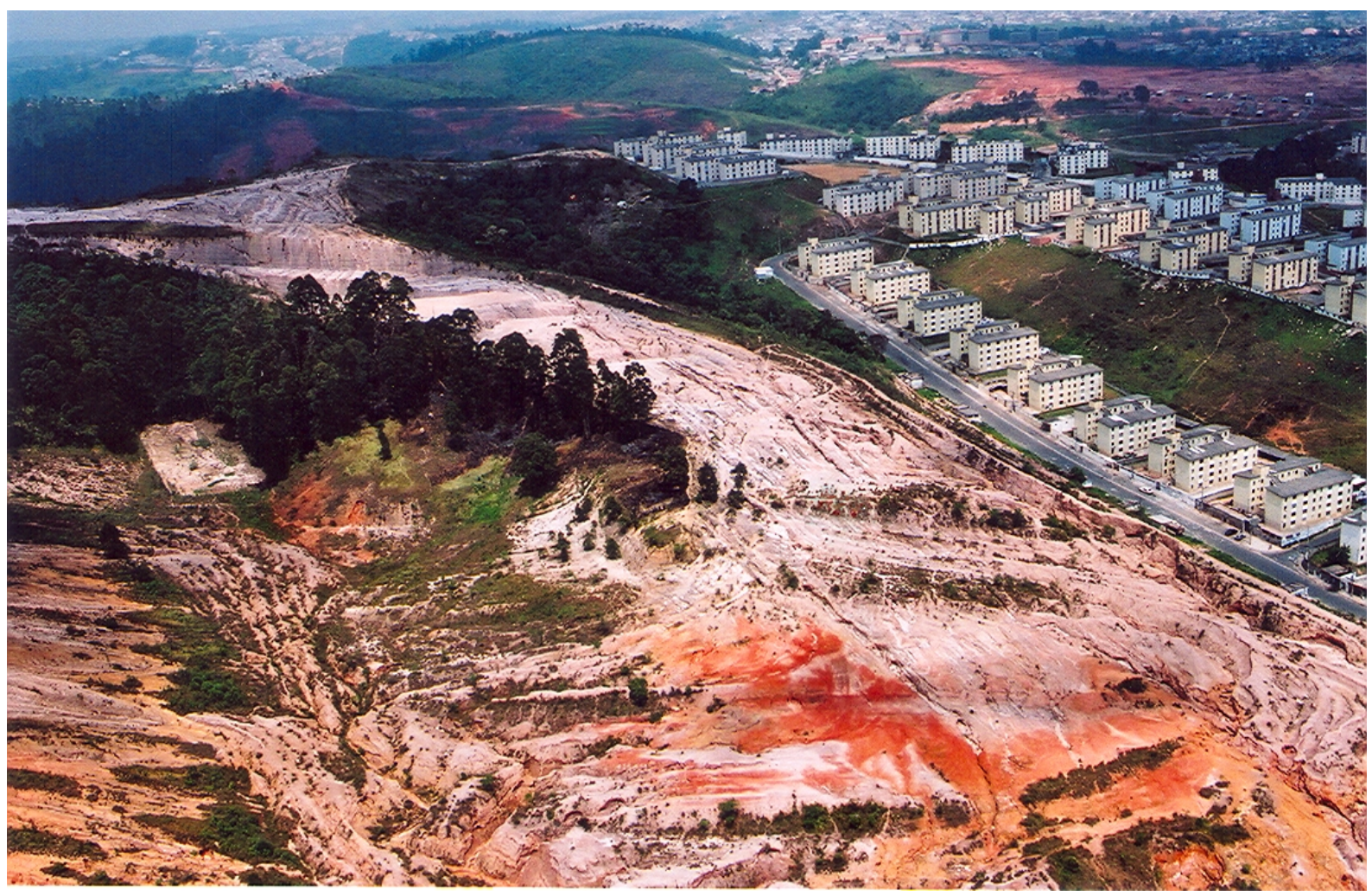

Conjunto Habitacional Santa Etelvina (Arquivo COHAB-SP)

A exigüidade do repertório de tipologias disponíveis explica grande parte dos grandes movimentos de terra, pois quando as tipologias não se adaptavam aos terrenos, esses deveriam ser a elas adaptados.

Do limitado repertório de tipologias da COHAB-SP, a que foi utilizada de forma mais extensiva é o "bloco de apartamentos", que representa 96.080 das 134.900 uh's de interesse social construídas pela Companhia (SLOMIANSKY, 2002, p. 56). Esses blocos, geralmente, têm de 4 a 5 pavimentos, com os térreos também destinados a apartamentos, plantas em forma de "H", são geminados e não possuem elevadores. 
A pequena distância entre as lâminas que formam o "H" em relação à altura dos prédios, prejudica a insolação e a ventilação dos compartimentos inferiores, que têm janelas voltadas para a área interna onde se localiza a caixa de escadas. Isso se agrava com a muito comum geminação entre blocos em "H", que cria fossos em que a iluminação e a ventilação são ainda mais comprometidas.

A ocupação dos térreos por apartamentos implica na redução da privacidade dessas unidades e obriga a que se implante, em áreas condominiais externas aos edifícios, equipamentos que são essenciais para seu funcionamento, mas que são verdadeiros trambolhos (abrigos de gás, centros de medição, lixeiras, caixas d'água), e ocupam espaços que poderiam ser melhor utilizados para implantação de caminhos, jardins, áreas de lazer, etc. $E$ também não permite a utilização dos térreos para o abrigo de veículos, tornando necessária a destinação de grandes áreas para estacionamentos.

Dessa forma, com a necessidade de se ocupar tantas áreas externas aos prédios com equipamentos que poderiam ser abrigados em seus térreos, fica bastante reduzida (ou talvez até anulada) a vantagem apontada para a utilização dos térreos por apartamentos, que estaria na diminuição do custo das unidades habitacionais, através de um aumento de densidade dos empreendimentos. PIGNANELLI (2003, p. 100-101) aponta para características e problemas semelhantes em tipologias adotadas também em larga escala pela CDHU (Companhia de Desenvolvimento Urbano e Habitacional do Estado de São Paulo).

Mas é importante lembrar, também, da posição de autores que se contrapuseram à crítica majoritária aos conjuntos da COHAB-SP. SACHS (1999, p. 219) diz que, ao discutir sobre os conjuntos implantados em Itaquera, Gabriel Bolaffi apontava para:

"o custo moderado das habitações, obtido precisamente graças às economias de escala, a despeito das irregularidades nos procedimentos dos apelos da oferta. A COHAB pôde comercializar o metro quadrado de habitação em Itaquera a 69 dólares, enquanto o preço médio em São Paulo elevava-se a, na época a 170 dólares. Ele reconhece que a qualidade arquitetônica dos primeiros prédios deixa muito a desejar, mas, no seu entender, a experiência dos primeiros canteiros de obras foi proveitosa para os arquitetos encarregados dos projetos implantados depois disso. Itaquera seria assim uma experiência válida de uma 
arquitetura de massa e mesmo "a principal obra arquitetônica realizada no Brasil". Consequentemente, as críticas que sofre - monotonia e tamanho reduzido dos apartamentos - parecem-Ihes exageradas".

SACHS diz também que, segundo Bolaffi:

"os grandes conjuntos de Carapicuíba e Itaquera constituem a parte mais válida da experiência da COHAB-SP, a despeito dos inúmeros erros cometidos. Bolaffi distingue vários tipos de erros: erros de detalhe ao nível da construção propriamente dita, devidos em parte ao caráter inovador das técnicas aplicadas e às quais as empresas de construção civil não estavam acostumadas; erros de execução também por causa da autorização dada aos moradores de se instalarem antes do término da construção dos equipamentos sociais. Mas ele critica principalmente a concepção urbanística desses conjuntos, inspirada ainda pela Carta de Atenas: a segregação espacial das funções urbanas, a construção dos conjuntos enquanto cidades-dormitórios sem atividades produtivas no local e, enfim, a ausência de áreas para postos de gasolina, pequenas oficinas de consertos, bares, etc.. Segundo Bolaffi, é preciso apontar esses erros em evidência para corrigí-los, em vez de condenar de uma vez por todas os grandes conjuntos habitacionais, cuja vantagem repousa nas economias de escala e no recurso às técnicas de construção modernas".

Vários autores discutem as razões da precariedade dos projetos dos conjuntos habitacionais de interesse social. Pode-se agrupar em duas vertentes principais as explicações que são dadas, que não entendo como antagônicas, mas como complementares. Uma parte dos autores aponta para um predomínio dos interesses econômicos na construção dos conjuntos e outra parte aponta para a predominância de uma determinada cultura de projeto.

Lizete RUBANO (2001, p. 60), como explicação sobre as razões da pobreza dos projetos da COHAB-SP, acrescenta que:

"a discussão deixa de ser voltada ao homem, à cidade, às formas de morar, ao programa e às referências da produção de outros países ou em outro momento da história brasileira, passando a ser tema dos empreendedores e da economia: como produzir muito, em um tempo determinado que viabilizasse a indústria da construção e os empresários da construção civil". 
A mesma autora localiza, na origem da implantação da política habitacional dos governos militares, quando ocorre a criação do BNH (Banco Nacional da Habitação), uma acentuação do "caráter empresarial e lucrativo da atividade construtiva voltada à habitação" e um desvirtuamento da "discussão conceitual e estética feita pelos arquitetos ligados ao Movimento Moderno, que se propunham a pensar uma nova maneira de vivenciar o urbano, com a habitação tendo um grande significado" (RUBANO, 2001, p. 18).

O que BONDUKI, ANDRADE E ROSSETTO (1993, p.67) dizem sobre projetos financiados pelo BNH também se aplica à COHAB-SP:

"habitação social, a partir do BNH, [.....] como questão de construção, de quantidade, de custo, de sistema financeiro [......] e abandonados aspectos importantes, como a participação do usuário no processo de produção e a preocupação com o projeto de arquitetura e urbanismo [......] O projeto, muitas vezes, tem sido elaborado ou detalhado pela própria empresa que vai edificar a obra, situação que destrói a fase da concepção, subordinando-a à produção."

Em “Origens da Habitação Social no Brasil”, BONDUKI (1998, p. 134-135) aponta para o início do empobrecimento dos projetos para habitação social num momento anterior ao $\mathrm{BNH}$, mas para o agravamento desse processo a partir da criação desse banco:

“[......] parte significativa dos arquitetos envolvidos com a produção de habitação social - sobretudo no âmbito dos IAPs e do Departamento de Habitação Popular do DF - adotou a atitude de projeto concebida pelo movimento moderno, buscando compatibilizar "economia, prática, técnica e estética" (Ferreira 1940:79), com o objetivo de viabilizar financeiramente o atendimento de trabalhadores de baixa renda, garantindo dignidade e qualidade arquitetônica. No Brasil, porém, os equívocos da ação habitacional implementada pelo governo reduziram o impacto e a abrangência da proposta. Houve, assim, uma incorporação apenas parcial dos princípios da arquitetura moderna, perdendo-se os generosos e desafiadores horizontes sociais, onde o resultado econômico não deveria se desligar da busca de qualidade arquitetônica e urbanística, e da renovação do modo de morar, com a valorização do espaço público.

Essa incorporação parcial gerou, em conseqüência, o empobrecimento gradativo dos projetos habitacionais ainda no final dos IAPS, chegando ao clímax na massiva produção implementada pelo BNH a partir de 1964, onde se manifesta 
apenas a busca cega e inútil pela redução de custos, sem levar em conta as outras perspectivas propostas pela arquitetura moderna. Com isso introduziu-se, no repertório da arquitetura da habitação no Brasil, um racionalismo formal, desprovido de conteúdo, consubstanciado em projetos de péssima qualidade, monótonos, repetitivos, desvinculados do seu contexto urbano e do meio físico e, principalmente, desarticulados de um projeto social."

COMAS (1986) entende que as concepções dos conjuntos de prédios de apartamentos que foram típicos do BNH e predominaram na produção da $\mathrm{COHAB}-$ $\mathrm{SP}$, foram influenciadas pelo que chama de "cidade ideal moderna". Segundo esse autor, enquanto os conjuntos de casas unifamiliares isoladas teriam sido muito criticados pela "intelligentsia" arquitetônica brasileira pelo desperdício de infraestrutura, os conjuntos de blocos de apartamentos (prédios) teriam sido poupados de crítica. E a razão dessa complacência, apesar dos aspectos negativos também verificados nesses últimos, decorreria do fato de que tinham características semelhantes às das superquadras de Brasília, reverenciadas por essa "intelligentsia" e que compunham o que Comas chama de "cidade ideal moderna".

\subsection{Obras - o predomínio da ótica das construtoras}

Aos problemas decorrentes da escolha da terra e da elaboração dos projetos, em muitos casos, foram acrescentados problemas na execução das obras, aos quais estariam relacionados 14.000 processos jurídicos movidos por mutuários contra a COHAB-SP, questionando patologias nos edifícios, na maioria: fissuras nas paredes, infiltrações em lajes e paredes e falhas nas instalações elétricas e hidráulicas (MARICATO, 1997, p. 51 e CASTRO, 1985).

No "Relatório de Gestão: 1989-1992" (COHAB, 1992, p. 13), aponta-se para um quadro crítico na gestão das obras, encontrado em janeiro de 1989, em que:

"a fiscalização não tinha condições de exercer o seu papel, por falta de projetos executivos completos, esquemas de controle e autoridade efetiva. Os projetos quando não eram incompletos ou inexistentes, eram mal dimensionados e mal quantificados, e baseavam-se em concepções urbanísticas totalmente 
equivocadas, que acarretavam imensos movimentos de terra, extremamente lesivos ao meio ambiente. Os contratos de obras, oriundos de licitações preparadas com projetos insuficientes, eram confusos e geravam planilhas de medições pouco confiáveis".

Na seqüência, esse relatório lista medidas que foram adotadas para que a COHAB promovesse correções e melhorias nos projetos e na gestão das obras. Mas esse trecho ilustra a grande autonomia que as empreiteiras tinham, em face do pequeno grau de interferência da COHAB, na execução das obras.

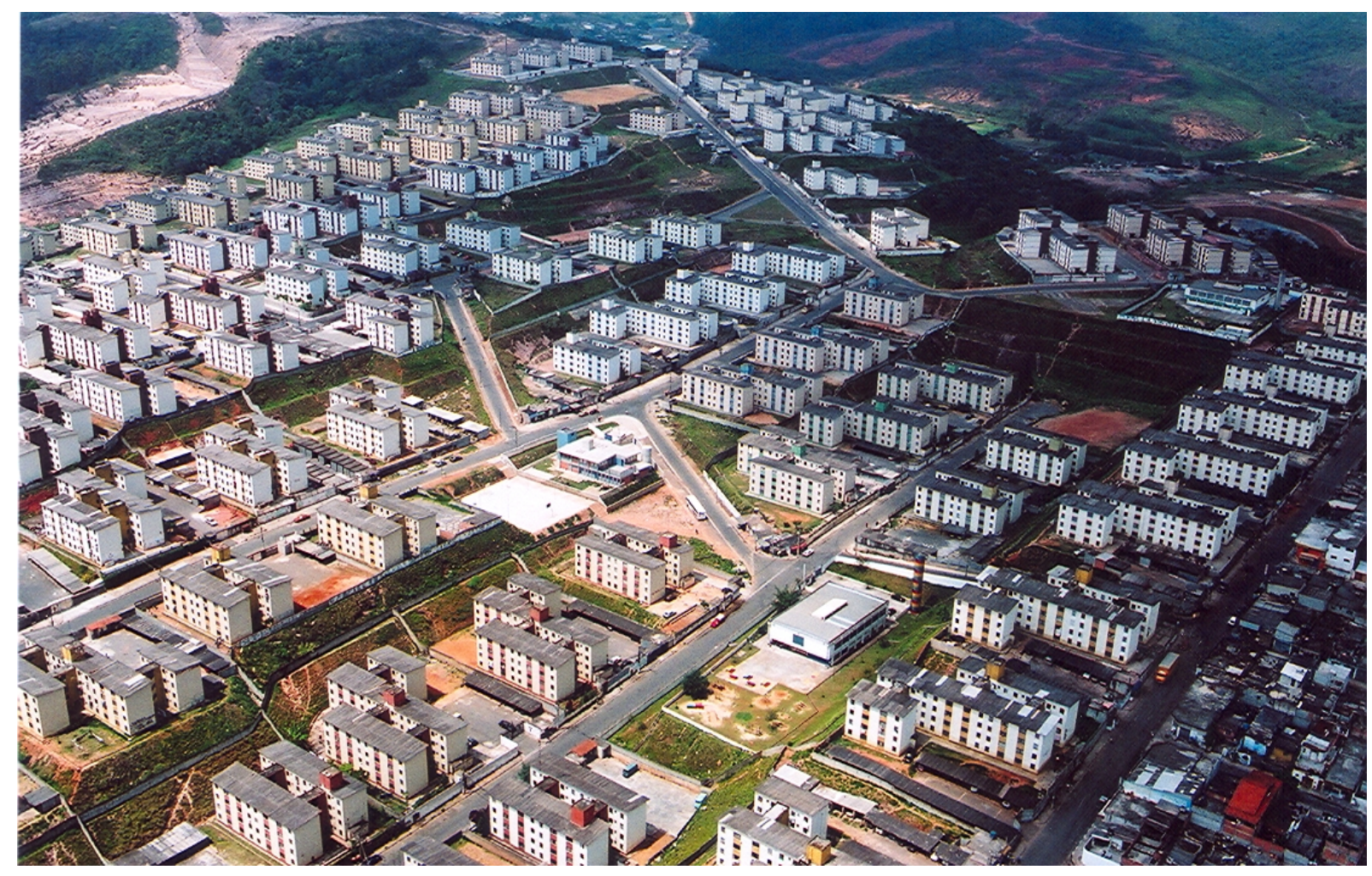

Conjunto Habitacional Santa Etelvina (Arquivo COHAB-SP)

Em relação a essa questão, NOGUEIRA (2003, p. 238) escreve:

"A COHAB desenvolvia os projetos-tipo como um arcabouço abstrato que servia a vários processos construtivos. Em geral a própria empresa construtora elaborava o projeto executivo, o que Ihe dava oportunidade de tratá-lo conforme seus interesses. $O$ que significava privilegiar a construtibilidade do empreendimento sobre o seu futuro uso. A empresa promotora, dessa forma, abria mão de um controle sobre o produto final. Mas o projeto deveria funcionar como instrumento privilegiado no sentido de conferir ao espaço qualidades sensíveis concretas: textura, cor, iluminação, conforto ambiental, sem falar na 
divisão interna e na adequação de cada espaço às suas funções. Os apartamentos reais que surgiam desse processo pareciam destinados à inabitabilidade."

Um dos casos extremos de problemas nas obras da COHAB é o dos edifícios construídos em Carapicuíba, com a utilização de um sistema pré-fabricado desenvolvido pela empresa COAN, que utilizava gesso na estrutura das suas paredes e, portanto, foi afetado pelas chuvas e apresentou graves patologias que motivaram sua demolição por implosão (COHAB-SP, 1989, p. 17).

\subsection{A irregularidade dos empreendimentos}

Por muito tempo, foi generalizada entre os agentes promotores de moradia popular, a prática de iniciar obras sem que estivessem plenamente equacionadas as questões fundiárias ou que os projetos tivessem sido aprovados pelos órgãos competentes, deixando a regularização para depois do término da obra. A CDHU, por exemplo, tinha 300 empreendimentos irregulares em 2001 (WERNA et al, 2001, p. 232).

Em decorrência de mudanças na legislação e de uma postura mais ativa de órgãos como as prefeituras municipais e o Ministério Público, recentemente, começou a se verificar uma maior preocupação entre esses agentes em cuidar da regularização fundiária e do licenciamento dos projetos antes do início das obras. A COHAB-SP não fugia à regra e possuía (e ainda possui) um grande número de conjuntos que demandam regularização. Segundo Maria da Graça P. SILVA (2004, p. 44-48), em dezembro de 2000, a COHAB tinha 33.493 unidades habitacionais não regularizadas e, dessas unidades, $81 \%$ estavam nessa situação há 11 anos e 37\% há 15 anos. Verificando-se casos, como os dos conjuntos Prestes Maia, Parque Ipê e Vila Maria I, em que a regularização demorou 20 anos.

Para essa mesma autora, mesmo considerando a pequena produção da COHAB-SP entre 1995 e 2000, o fato de 80\% das unidades habitacionais produzidas nesse período estarem regularizadas seria um indicador de uma nova postura de maior cuidado com a regularização. E no caso dessa Companhia, também teria contribuído a mudança da principal instituição em que eram obtidos 
seus financiamentos. O BNH não exigia que os terrenos e projetos estivessem regulares, ao contrário da CEF, sua sucessora.

Para os moradores dos empreendimentos, a situação de irregularidade implica no impedimento do registro da propriedade, depois da quitação do financiamento, seja pela conclusão dos pagamentos ou pela morte do titular do contrato; e também em dificuldades na obtenção de atendimento pela Prefeitura, para a execução de serviços de manutenção do sistema viário, praças e áreas institucionais e para a simples colocação de placas com nome das ruas. Para o município, redunda na impossibilidade de incluir os conjuntos habitacionais no Mapa Oficial da Cidade (MOC) e de efetuar o lançamento do IPTU (Imposto Predial e Territorial Urbano) correspondente (SILVA, 2004, p. 226-227).

\subsection{Críticas formuladas por partidos políticos}

Tratando-se das críticas que foram feitas ao antigo modelo da COHAB, é importante destacar as críticas que foram feitas especificamente pelo partido político da Prefeita Marta Suplicy e da equipe que dirigiu essa companhia entre 2001 e 2004, período sobre o qual está o foco desta dissertação.

Em "As Eleições de 82 - O PT e a Questão Municipal” (DANIEL, 1981, p. 65), um dos primeiros documentos do PT sobre políticas públicas, é dito que poucos dos programas do $\mathrm{BNH}$, do qual a COHAB-SP era agente promotor e financeiro, atingiam a população de baixa renda.

Em "O Modo Petista de Governar" (BITTAR (org.), 1992, p. 44), fala-se que:

"é fundamental a contraposição radical aos padrões impostos pelo $B N H e$, posteriormente, pela Caixa Econômica Federal, que consolidaram uma visão anti-social do problema da moradia. Esta política, sem levar em conta as condições regionais, acumulou uma série de erros e equívocos: gestão centralizada e autoritária, gerada em Brasília e implantada a nível municipal e estadual pelas COHAB's, verdadeiras filiais do BNH; distribuição regional dos recursos orientada por critérios político-eleitorais e clientelistas; absoluta 
desarticulação entre política urbana e habitacional; ausência de canais de participação popular na formulação e gestão da política e dos recursos; exclusão dos usuários na concepção dos programas e projetos; não utilização de recursos a fundo perdido e ausência de subsídios; critérios não sociais de financiamento; adoção da casa própria e da unidade habitacional pronta como único processo de acesso ao financiamento habitacional; total desprezo pelo projeto arquitetônico e urbanístico com clara preferência por soluções uniformizadas e padronizadas; preferência pela implantação de conjuntos nas periferias extremas das cidades, estimulando a especulação imobiliária e, finalmente, absoluto distanciamento entre produção habitacional pública e práticas espontâneas e clandestinas que garantem a produção da cidade real, onde a maioria da população vive". 


\section{Capítulo 3:}

\section{As condicionantes da nova política adotada entre 2001 e 2004}

\subsection{A demanda por habitação social em S. Paulo, segundo o Plano Municipal de Habitação de 2004}

Nesta parte do trabalho, serão apresentados dados relativos à demanda por habitação no Município de São Paulo, cujo atendimento, numa parcela significativa, compete à COHAB-SP. Os dados relativos a essa demanda foram obtidos no Plano Municipal de Habitação, elaborado pela Secretaria Municipal de Habitação e Desenvolvimento Urbano, em 2004, de acordo com a determinação da Lei 13.430, de 13/09/02, que instituiu o Plano Diretor Estratégico.

Em seu diagnóstico sobre as características e dimensões do problema habitacional no Município de São Paulo (MSP), o Plano apresenta dados da demanda relativos ao ano de 2000, faz projeções sobre o seu crescimento e estima os investimentos necessários para o seu atendimento até 2012, ano colocado como horizonte das ações por ele (Plano) previstas. Os dados são resumidos em vários quadros dentre os quais destacamos os seguintes:

a. Inadequação dos domicílios por tipo de assentamento - relativo ao ano de 2000 (Quadro 1).

b. Síntese das Necessidades Habitacionais Atuais (Quadro 2).

c. População e número de domicílios em favelas e loteamentos irregulares, entre 2000 e 2012 (Quadro 3).

d. Síntese das necessidades habitacionais do MSP, projetadas até 2012, e estimativa de custos (Quadro 4). 
Tabela 3.1 - Inadequação do domicílio por tipo de assentamento, Município de São Paulo, 2000

\begin{tabular}{c|c|c|c|c|c|c}
\hline Indicadores & Favelas & $\begin{array}{c}\text { Loteamentos } \\
\text { irregulares de } \\
\text { baixa renda }\end{array}$ & $\begin{array}{c}\text { Conjuntos } \\
\text { habitacionais }\end{array}$ & Cortiços & $\begin{array}{c}\text { Moradores } \\
\text { de rua (3) }\end{array}$ & Total \\
\hline População & 1.160 .597 & 1.062 .158 & 89.760 & $38.512(2)$ & 8.706 & 2.359 .733 \\
\hline Domicílios & $291.983(1)$ & $283.476(1)$ & 24.000 & $14.617(2)$ & 3.212 & 617.288 \\
\hline Habitante/ domicílio & 3,97 & 3,74 & 3,74 & 2,63 & 2,71 & 3,82 \\
\hline Renda média (SM) & 1,80 & 3,48 & nd & nd & nd & \\
\hline Densidade média (hab/ha) & 380 & 132 & nd & - & - & \\
\hline
\end{tabular}

(1) - Inclui domicílios em áreas de risco, bem como em áreas de mananciais

(2) - Valores referentes apenas aos 9 setores básicos da área central, pesquisados pela SEADE/CDHU p/ o PAC/BID

(3) - Dados do Censo de Moradores de Rua elaborado pela FIPE (2000)

Fonte: Plano Municipal de Habitação, SEHAB, 2004, p. 31

Tabela 3.2 - Síntese das necessidades habitacionais em 2000

\begin{tabular}{cc}
\hline $\begin{array}{c}\text { Necessidades por tipo de } \\
\text { intervenção }\end{array}$ & Domicílios \\
\hline Provisão de novas moradias & 62.294 \\
\hline $\begin{array}{c}\text { Urbanização de favelas } \\
\text { Urbanização de loteamentos de } \\
\text { baixa renda }\end{array}$ & 239.110 \\
\hline $\begin{array}{c}\text { Melhorias em conjuntos } \\
\text { habitacionais }\end{array}$ & 264.952 \\
\hline Melhorias em cortiços & 24.000 \\
\hline & Total
\end{tabular}

Fonte: Plano Municipal de Habitação, SEHAB, 2004, p. 32

Considera-se que a provisão de novas moradias deverá atender a:

$15 \%$ do total dos domicílios nas intervenções de urbanização de favelas:

4\% do total de domicílios nas

$40 \%$ do total de domicílios nas intervenções em cortiços; intervenções de recuperação de loteamentos irregulares; $100 \%$ dos moradores de rua. 
Tabela 3.3- População e número de domicílios em favelas e loteamentos irregulares, em 2000 e 2012

\begin{tabular}{|c|c|c|c|c|c|c|}
\hline \multirow{2}{*}{ Ano } & \multirow{2}{*}{$\begin{array}{l}\text { Hipótese } \\
\text { densidade }\end{array}$} & \multicolumn{2}{|c|}{ Favelas } & \multicolumn{2}{|c|}{ Loteamentos } & \multirow{2}{*}{$\begin{array}{l}\text { Mun. São } \\
\text { população }\end{array}$} \\
\hline & & população & domicílio & população & domicílio & \\
\hline 2000 & ......... & 1.160 .597 & 291.983 & 1.062 .158 & 283.476 & 10.434 .252 \\
\hline \multirow{2}{*}{2012} & Baixa & \multirow{2}{*}{1.509 .590} & 401.086 & \multirow{2}{*}{1.469 .695} & 391.919 & \multirow{2}{*}{11.591 .032} \\
\hline & Alta & & 421.247 & & 415.168 & \\
\hline
\end{tabular}

Fonte: Plano Municipal de Habitação, SEHAB, 2004 - ps. 47 e 48

Tabela 3.4 - Síntese das necessidades habitacionais do MSP, projetadas até 2012, e estimativa de custos

\begin{tabular}{|c|c|c|c|}
\hline $\begin{array}{c}\text { Necessidades por tipo de } \\
\text { intervenção }\end{array}$ & Domicílios & $\begin{array}{c}\text { Custol } \\
\text { domicílio }\end{array}$ & Custo total \\
\hline Provisão de novas moradias & 99.050 & $\mathrm{R} \$ 32.000,00$ & $R \$ 3.169 .600 .000,00$ \\
\hline Urbanização de favelas & 340.923 & $\mathrm{R} \$ 12.000,00$ & $\mathrm{R} \$ 4.091 .076 .000,00$ \\
\hline $\begin{array}{l}\text { Urbanização de loteamentos de } \\
\text { baixa renda }\end{array}$ & 376.242 & $\mathrm{R} \$ \quad 3.100,00$ & $\mathrm{R} \$ 1.166 .350 .200,00$ \\
\hline $\begin{array}{c}\text { Melhorias em conjuntos } \\
\text { habitacionais }\end{array}$ & 24.000 & $\mathrm{R} \$ 2.000,00$ & $48.000 .000,00$ \\
\hline Melhorias em cortiços & 30.000 & $\mathrm{R} \$ 4.000,00$ & $120.000 .000,00$ \\
\hline Total & 870.215 & ...... & $R \$ 8.595 .026 .200,00$ \\
\hline
\end{tabular}

Fonte: Plano Municipal de Habitação, SEHAB, 2004, p. 49

A leitura desses quadros expõe a gravidade do problema habitacional do MSP e os altos investimentos que terão que ser feitos para equacioná-lo. Em 2004, estimava-se que havia 600 mil famílias que necessitavam de uma das vários formas de atendimento habitacional: provisão de novas moradias, urbanização de favelas e de loteamentos de baixa renda (na maioria, clandestinos), melhorias em conjuntos habitacionais deteriorados, melhorias em cortiços.

No item provisão de novas unidades, estimou-se que será necessário construir 99.050 uh's novas (que incluiriam reforma de prédios já existentes e sua reconversão para HIS), que é um número que se aproxima de $70 \%$ das unidades construídas pela COHAB-SP até 2004 (141.711 uh's). Portanto, terá que ser muito 
grande o esforço dessa Companhia, até 2012, para a redução (ou eliminação) do déficit habitacional no MSP como proposto pelo Plano de Habitação. Além do que teria que assumir também parcelas significativas das outras formas de atendimento habitacional acima mencionadas, afora da provisão.

\subsection{As idéias que a nova gestão trazia}

A habitação é uma das áreas em que o Partido dos Trabalhadores (PT), ao qual Marta Suplicy pertence, tem um dos maiores acúmulos na formulação e na execução de políticas públicas. Dos grupos de trabalho que, no Partido, têm tratado do assunto participam militantes de movimentos populares por moradia, técnicos que prestam assessoria a esses movimentos, técnicos da administração pública e professores e estudantes universitários. Dessa forma, nesses grupos mesclam-se expectativas, preocupações e experiências desses vários atores.

As experiências efetivadas na gestão Erundina, a primeira do PT na Prefeitura de São Paulo (1989-1992), e nos governos de outras prefeituras, sobretudo as do $A B C$, tiveram grande influência na formulação do programa de governo da então candidata Marta Suplicy. Na década de 90, como resposta ao crescimento da demanda e ao encolhimento das políticas federais para habitação, haviam se consolidado importantes experiências municipais na área de moradia social, como apontado por CARDOSO e RIBEIRO ${ }^{12}$, BONDUKI ${ }^{13}$ e GORDILHOSOUZA $^{14}$.

\footnotetext{
12 "A Municipalização de Políticas Habitacionais: Uma Avaliação da Experiência Recente (19931996)".

13 “Habitat - As Práticas Bem-Sucedidas em Habitação, Meio Ambiente e Gestão Urbana nas Cidades Brasileiras".

14 "Habitar Contemporâneo: Novas Questões no Brasil dos Anos 90".
} 
Mas também influenciaram o processo de preparação do programa de governo, o Projeto Moradia, formulado no Instituto Cidadania ${ }^{15}$, que continha um amplo diagnóstico e propostas para a questão da moradia no Brasil, e as idéias que vinham do movimento pela Reforma Urbana, que, dentre outras coisas, foi o maior responsável pela Emenda Popular que introduziu dispositivos de reforma urbana na Constituição de 1988 e cuja regulamentação por meio de lei ordinária, resultou no Estatuto da Cidade. O movimento pela Reforma Urbana, depois, organizou-se como o Fórum Nacional da Reforma Urbana.

O Programa de Governo da, então, candidata a Prefeita Marta Suplicy, foi elaborado no Instituto Florestan Fernandes ${ }^{16}$. As reuniões nesse Instituto que tratavam de habitação tiveram a participação de um grupo com a composição tradicional dos grupos de trabalho do PT para a área de habitação já mencionados.

Esse grupo, no geral, tinha uma expectativa de forte atuação do Município nas questões de habitação seguindo a tendência das gestões anteriores, sobretudo da gestão de Luiza Erundina, e a tendência apontada na literatura anteriormente mencionada. E convergia em torno de um ideário que se traduziu no Programa de Governo da candidata Marta Suplicy, que, antes de ser formalmente aprovado, constituiu o conjunto de diretrizes para o Programa de Governo apresentado a seguir:

\section{"Diretrizes para o Programa de Governo da Candidata do PT a Prefeita em 2000}

Política habitacional Habitação e suas principais interfaces

A seguir são expostos os princípios da política habitacional que o governo do PT realizará durante sua gestão. Os três projetos de intervenção apresentados a seguir, de certa forma, dão conta da ampla diversidade de problemas habitacionais hoje presentes na cidade de São Paulo, embora sem esgotar a totalidade de possíveis ações da prefeitura neste campo.

\footnotetext{
15 O Instituto Cidadania, na época, era presidido pelo atual Presidente da República Luiz Inácio Lula da Silva e, para esse projeto, contou com a parceria da Fundação Djalma Guimarães e da Cooperativa Habitacional dos Bancários. O Projeto Moradia teve como coordenadores temáticos: André Luiz de Souza, Ermínia Maricato, Evaniza Rodrigues, lara Bernardi, Lúcio Kowarick, Nabil Bonduki e Pedro Paulo Martoni Branco. E como coordenadores executivos: Clara Ant e Tomás Moreira.

${ }^{16} \mathrm{O}$ Instituto Florestan Fernandes tinha como presidente Marta Suplicy e como vice-presidente o Prof. Aziz Ab'Saber. Foi criado com o objetivo de pensar e propor políticas públicas para o Município de São Paulo. Para a área de habitação, teve como coordenadores Nabil Bonduki e Evaniza Rodrigues, e para a área de desenvolvimento urbano, Jorge Wilheim e Raquel Rolnick.
} 


\section{Princípios}

- Moradia é um direito social

Conceituação de moradia digna, envolvendo desde a unidade habitacional, com qualidade e conforto, ao espaço público, infra-estrutura básica (água, esgoto, energia elétrica, drenagem), equipamentos sociais, de lazer, cultura e gestão local. Garantir o acesso ao direito à moradia e ao direito à cidade, construindo e requalificando territórios de sociabilidade e gestão da cidade, que estimule o convívio, as diferentes formas de organização e expressão e valorize o espaço público e o seu uso coletivo.

- Prioridade para a população de baixa renda

Toda a ação nesta área priorizará o atendimento das camadas de mais baixa renda da população, de acordo com a distribuição do déficit na cidade, em um claro caráter de redistribuição dos recursos públicos, atendendo quem mais necessita e quem não tem acesso às outras formas de financiamento habitacional governamental ou de mercado. Possibilitar a população de baixa renda que constrói na periferia irregularmente (passível de multa do mesmo valor que os bairros nobres) plantas de casas térreas na prefeitura e cursos em parceria com o sistema S (SENAI, SESC, etc.) para capacitação dos construtores adequando assim as construções ao plano de urbanização da cidade de SP.

- Articulação da política habitacional com a política urbana

A política habitacional deve estar articulada com a política urbana (reforma urbana, saneamento e transporte) bem como com as políticas sociais, de combate à exclusão e de combate à violência, como parte integrante destas. Elaboração de plano integrado de habitação, com as diretrizes gerais de intervenção, evitando as intervenções pontuais, fora do contexto.

- Participação popular e controle social

Criação de mecanismos e instâncias de participação em todos os níveis na definição das políticas e prioridades, alocação de recursos e implementação dos programas. Reformulação do Conselho Municipal de Habitação, com ampla representação regional e setorial. Democratização do Fundo Municipal de Moradia. Criação das Conferências de Habitação e compatibilização com as demais formas de participação da gestão, como o Orçamento Participativo e as instâncias locais nas Sub-prefeituras.

- Estímulo à autogestão

Incentivo às cooperativas, movimentos e associações em processos autogestionários na efetivação dos programas habitacionais.

\section{- Respeito ao meio ambiente}

Compatibilização das intervenções com a preservação e o respeito ao meio ambiente, buscando intervir em áreas degradadas no sentido de garantir o direito à moradia e recuperar a qualidade ambiental. Impedir a ocupação predatória de novas áreas, através de fiscalização ao lado da busca de alternativas para a demanda existente, promoção de campanhas de educação ambiental. Sustentabilidade social, econômica e ambiental como requisito de atuação.

- Diversidade de projetos e programas

Desenvolvimento de alternativas específicas para cada tipo de problema de moradia, levando em consideração a população local, as formas de organização, as condições físicas e econômicas do local, e evitando as soluções padrão e flexibilizando as normas de maneira a atender as necessidades dos diferentes tipos de intervenção. 


\section{- Descentralização}

Reestruturação do setor, compatibilizando-o com a nova estrutura proposta para as sub-prefeituras, descentralizando a ação, garantindo maior acesso do morador aos órgãos responsáveis pela intervenção.

\section{- Subsídio para a baixa renda}

Os recursos municipais deverão ser utilizados de maneira a complementar e subsidiar os recursos onerosos, que deverão ser obtidos junto aos governos estadual e federal e outros órgãos de financiamento, de maneira a garantir o acesso das famílias de baixa renda, hoje excluídas desse tipo de financiamento.

\section{- Criação de novas fontes de recursos}

Obtenção de recursos gerados pelo processo imobiliário, como IPTU progressivo e outras formas de captação, destinando-os à política habitacional. . Articular a aplicação dos recursos estaduais (ICMS) e federais (FGTS e OGU) no município, compatibilizando o investimento com a política habitacional local.

\section{- Obras em andamento}

Conclusão das obras em andamento, com revisão de contratos, adequações e aperfeiçoamentos para que estes se enquadrem na política habitacional a ser desenvolvida. Priorizar a conclusão dos empreendimentos que se encontram paralisados desde 1992.

\section{- Estímulo ao setor privado}

Baratear a produção da moradia visando o acesso dos setores médios à aquisição de moradia através do mercado, para que estes deixem de pressionar as políticas e os recursos públicos, que deverão atender prioritariamente à baixa renda.

- Geração de emprego e estímulo à economia

O investimento e o estímulo à área da habitação são grandes fontes potenciais de geração de emprego diretos e indiretos, bem como ativador da economia local. A implementação de uma política pública de habitação atenderá, portanto, não só aos interesses daqueles que a demandam, como também de toda a cidade.

\section{- Estímulo ao desenvolvimento tecnológico}

Realização de parcerias com universidades e institutos de pesquisa visando o desenvolvimento de alternativas de menor custo, maior qualidade e produtividade. Criação de programa de qualidade na construção civil.

\section{- Assistência técnica e jurídica}

Parceria com organizações sociais e movimentos sociais visando garantir assistência técnica gratuita para a população de baixa renda.

\section{Projetos}

Os projetos propostos são os seguintes:

- Projeto Bairro Legal, que objetiva a regularização fundiária, a qualificação urbanística e a melhoria ou construção das unidades habitacionais em assentamentos existentes, ou seja, em favelas, loteamentos irregulares, mutirões, áreas de risco e conjuntos habitacionais.

- Projeto Morar Perto, que objetiva a produção de unidades habitacionais nas áreas centrais ou de urbanização consolidadas na cidade, através de reforma ou reciclagem de prédios e imóveis ociosos e construção de pequenos conjuntos habitacionais em áreas vazias ou sub-utilizadas.

- Projeto Construir Barato e Direito, que objetiva desenvolver ações tanto no âmbito de política fundiária como mudanças na legislação de zoneamento e código de obras para facilitar o processo de aprovação de projetos habitacionais e baratear o custo da terra e da obra, facilitando tanto a produção privada quanto à produção pública de moradia." 


\subsection{A situação da COHAB-SP e da Prefeitura no início de 2001}

Como já dito, a principal fonte de recursos com que a COHAB-SP havia contado, até a criação do Fundo Municipal de Habitação, havia sido o SFH, que, para a habitação social, utilizava dotações do FGTS. A essa fonte a COHAB não mais poderia recorrer, após o acordo de refinanciamento da dívida do Município de São Paulo, firmado com a União, em 2000, ao final da gestão de Celso Pitta, pois, a partir daí, ficou impedida de contrair novos financiamentos. ${ }^{17}$.

Dessa forma, a disponibilidade de recursos pela COHAB estaria, em grande medida, dependente daqueles que pudessem a ela ser destinados pelo Orçamento do Município de São Paulo. Por sua vez, esse Orçamento estava muito comprometido, no início de 2001. Havia uma dívida de curto prazo superior a $R \$ 2$ bilhões (em valores de julho de 2005), que vinha da gestão Pitta e para a qual não haviam reservas em caixa. Existia também um estoque de dívida de longo prazo, que havia sido renegociada pelo prefeito Celso Pitta com o governo federal, na gestão de Fernando Henrique Cardoso, cujo valor, em dezembro de 2000, estava próximo a $\mathrm{R} \$ 14,5$ bilhões. Esse valor foi crescendo e, ao final de 2004, chegou a $\mathrm{R} \$ 29$ bilhões.

O contrato que formalizou essa renegociação exigia que a Prefeitura de São Paulo destinasse $13 \%$ de sua receita líquida real mensal ao pagamento da dívida e que pagasse, em novembro de 2002, uma parcela extra de $R \$ 3,095$ bilhões. Em caso de não pagamento dessa parcela, haveria um aumento dos juros incidentes de $6 \%$ para $9 \%$ ao ano. Segundo o Secretário de Finanças da Prefeitura, José Carlos Fernandes Afonso, esse pagamento não se efetivou porque o Orçamento Municipal não comportava, já que seu valor correspondia a quatro meses da arrecadação total da Prefeitura e a quase o mesmo valor do total investido em saúde e educação em 2002 (AFONSO, 2006, p. 221).

\footnotetext{
17 PMSP - Região Metropolitana de S. Paulo: gestão em debate, p. 60, ww2.prefeitura.sp.gov.br//arquivos/secretarias/governo/publicacoes/RMCADERNO2.pdf
} 
Do ano de 2001 para o de 2004, um grande esforço de recuperação financeira foi feito pela Prefeitura, que, dentre outra coisas, resultou em um aumento da receita total de $17 \%$, principalmente, pela elevação do que se arrecadava com o IPTU, através da revisão da Planta Genérica de Valores e da adoção da progressividade das alíquotas, e da criação da taxa do lixo. Em valores de julho de 2005, atualizados pelo IPCA-IBGE, a receita evoluiu da seguinte forma:

\begin{tabular}{|c|c|}
\hline 2001 & $\mathrm{R} \$ 12,662$ bilhões \\
\hline 2002 & $\mathrm{R} \$ 12,358$ bilhões \\
\hline 2003 & $\mathrm{R} \$ 12,458$ bilhões \\
\hline 2004 & $\mathrm{R} \$ 14,049$ bilhões \\
\hline 2001-2004: & $\mathrm{R} \$ 51,529$ bilhões \\
\hline
\end{tabular}

$\mathrm{Na}$ área da habitação especificamente, havia contratos dos programas PROVER (Programa de Verticalização de Favelas, mais conhecido por Cingapura) e PROCAV (canalização de córregos e implantação de avenidas de fundo de vale), financiados pelo BID que, no início da gestão Marta Suplicy, tinham saldos de recursos com os quais foram construídas 5 mil uh's, de 2001 a 2004, sendo 2,2 mil no PROVER e 2,8 mil no PROCAV ${ }^{18}$. Dessas uh's, 1,4 mil do PROVER e as 2,8 mil do PROCAV já estavam em obras no final de $2000{ }^{19}$.

O Contrato de Empréstimo $n^{\circ}$ 938/OC, para financiamento do PROVER, havia sido assinado entre a PMSP e o BID em 11/07/96 e previa o investimento de US\$ 250 milhões, composto de US\$150 milhões de aportes do BID e US\$100 milhões da contrapartida municipal. Por solicitação da PMSP no início de 2001 o prazo desse contrato foi prorrogado até dezembro de 2003, com previsão de desembolsos de US\$ 32,5 milhões em 2002 e US\$ 15,3 milhões em 2003 (SEHAB, "Propostas para Atendimento à Ajuda Memória da Missão de Administração de Agosto de 2001").

\footnotetext{
${ }^{18}$ FERREIRA, in GASPAR, AKERMAN e GARIBE, 2006, p. 183.

${ }^{19}$ Power point da apresentação do Programa. de Provisão Habitacional, na $1^{\text {a }}$. Conferência Municipal de Habitação, 7 a 9/9/2001.
} 
Até o final de 2003, haviam sido desembolsados US\$247,23 milhões, sendo US\$ 99,79 de aporte local e US\$ 147,31 de aporte do BID ${ }^{20}$. Segundo Rossella ROSSETTO (2003, p. 75), para o PROVER foram empenhados $R \$ 22,29$ milhões em 2001 e R\$ 28,28 milhões em 2002 e previstos R\$ 45,00 milhões para 2003.

No início de 2001, parcela dos técnicos que assumiram cargos de confiança na SEHAB e na COHAB, a partir do início da gestão de Marta Suplicy, demonstraram preocupação de que a continuidade do PROVER em um ritmo forte e, portanto, a destinação a ele de montantes consideráveis do orçamento municipal para habitação poderia comprometer a continuidade de programas iniciados na gestão Erundina e, depois, paralisados ou semi-paralisados, como era o caso do de Mutirões com Autogestão, e o deslanche de novos programas como, por exemplo, o Programa Morar no Centro.

No início da gestão, o orçamento da PMSP estava bastante comprometido e da mesma forma o da SEHAB. No caso específico da COHAB, também havia um grande constrangimento orçamentário. Em 2000, ela tivera como principais despesas:

Tabela 3.6 - Principais despesas da COHAB em 2000

\begin{tabular}{|c|c|c|}
\hline $\begin{array}{l}\text { - Retorno à CEF e ao BB pelos } \\
\text { financiamentos tomados para a } \\
\text { construção de conjuntos habitacionais: }\end{array}$ & $\mathrm{R} \$ 91.229 .915$ & $48,12 \%$ \\
\hline - Folha de pagamentos + encargos: & $\mathrm{R} \$ 35.129 .730$ & $18,53 \%$ \\
\hline $\begin{array}{l}\text { - Seguros SFH/outros relativos aos } \\
\text { imóveis da carteira: }\end{array}$ & $\mathrm{R} \$ 29.209 .160$ & $15,41 \%$ \\
\hline - Serviços de terceiros: & $\mathrm{R} \$ 8.641 .324$ & $4,56 \%$ \\
\hline - Total dessas despesas & $\mathrm{R} \$ 164.210 .129$ & $86,62 \%$ \\
\hline
\end{tabular}

${ }^{20}$ LOZANO, 2004, Anexo A 
Nesse mesmo ano, as principais receitas tinham sido:

Tabela 3.7 - Principais despesas da COHAB em 2000

\begin{tabular}{|c|c|c|}
\hline - Aumento de Capital: & $\mathrm{R} \$ 84.360 .000$ & $44,06 \%$ \\
\hline $\begin{array}{l}\text { - Recebimentos imobiliários } \\
\text { (pagamento pelos mutuários): }\end{array}$ & $\mathrm{R} \$ 55.088 .723$ & $28,77 \%$ \\
\hline $\begin{array}{l}\text { - Seguros SFH/outros relativos aos } \\
\text { imóveis da carteira: }\end{array}$ & $\mathrm{R} \$ 28.797 .996$ & $15,04 \%$ \\
\hline - Fundo Municipal de Habitação: & $\mathrm{R} \$ 8.240 .665$ & $4,30 \%$ \\
\hline - Total dessas receitas & $\mathrm{R} \$ 176.487 .384$ & $92,17 \%$ \\
\hline
\end{tabular}

(fonte: COHAB-SP, Relatório Zero, p. 19)

Esses quadros demonstram o quanto era grande a dependência da COHAB ao Tesouro Municipal. Do qual, ao longo de 2000, havia recebido R\$ 92.600.665, sendo $R \$ 84.360 .000$ como aumento de capital e $R \$ 8.240 .665$ de investimentos do FMH. Os aportes de recursos da PMSP na COHAB, como aumento de capital, destinavam-se a cobrir, principalmente, o custeio (em cuja composição tinham maior peso a folha de pagamento e encargos trabalhistas) e o déficit de $R \$$ 36.221.192, que havia na conta com o SFH, decorrente da diferença entre o valor recebido dos mutuários (recebimentos imobiliários $=R \$ 55.088 .723$ ) e o valor que tinha que devolver por ano à CEF/SFH (R\$ 91.229.915).

Déficit esse que resultava de uma alta inadimplência. Em novembro de 2000 , os valores não pagos à COHAB pelos seus mutuários totalizavam $R \$ 469$ milhões e, do total de 103.022 mutuários, 75.486 (73,27\% do total) tinham prestações em atraso. Grande parte dessa inadimplência estava localizada ente os 14.565 mutuários do Conjunto Santa Etelvina, em que os valores em atraso somavam R\$ 255 milhões $(54,4 \%$ do total). Mas também era significativa a inadimplência nos conjuntos construídos para o atendimento a famílias de classe média, chamados de Renda Média -Brás, Bresser, Jabaquara-, onde residiam mutuários em relação aos quais a COHAB tinha $R \$ 59$ milhões de créditos a receber.

A disparidade entre o valor do aumento de capital e dos investimentos do FMH foi objeto de críticas, nas discussões sobre Programa de Governo, no Instituto 
Florestan Fernandes. As críticas foram feitas talvez por não se conhecer direito a destinação do aumento de capital. Mas, em parte, tinham sentido, pois o custeio era alto, com um grande número de cargos de confiança usados para barganhas políticas e com grandes mordomias para a direção da companhia. Situação mudada em 2001, com demissões e corte das mordomias (verba de representação, etc.). Dentro do esforço de reduzir custeio, também foi efetuada uma redução de $5 \%$ dos salários dos funcionários em cargos de confiança, implementado um Plano de Demissão Voluntária, revistos contratos de prestação de serviços, etc. (COHAB-SP, Relatório de Gestão 2001-2004, 2004, p. 84)

Mas a alta inadimplência, maior causa do déficit na conta do SFH, não seria tão facilmente reduzida, apesar de todas as campanhas. E a cobertura desse déficit pelo MSP acaba se constituindo, efetivamente, no maior subsídio que concede à habitação de interesse social, se bem que, dessa forma, acabe também subsidiando aos mutuários inadimplentes dos conjuntos de renda média.

Se para a melhoria das finanças da COHAB-SP era necessária a redução da inadimplência nos conjuntos financiados pelo SFH, para a melhoria das finanças da sua mais importante fonte de recursos a partir de 1994, o FMH, era necessária a comercialização de unidades construídas com recursos do MSP, através do FUNAPS e do próprio FMH, e ainda não comercializadas. No início de 2001, havia 23.833 uh's (13.440 por mutirão e 10.393 por empreiteiras) concluídas ou em fase de conclusão que necessitavam de comercialização.

Estimava-se, à época, que a comercialização dessas unidades poderia permitir uma receita potencial mensal de $R \$ 621.270,00$ para a COHAB, pela administração dessa carteira (COHAB-SP, "Relatório Zero", p. 25).

A difícil situação financeira da COHAB-SP e o pouco volume de recursos que recebia por intemédio do $\mathrm{FMH}$, que se verificava na gestão Pitta, não permitiam que efetuasse investimentos em novas obras em valores significativos. No entanto, conforme já se falou, os seus dispêndios com custeio continuavam altos. Sobre esse paradoxo, o livro "Pluralismo na Habitação" (WERNA et al, 2001, p. 285) afirma: "[....... a COHAB-SP está hoje ineficaz e ineficiente. Isto significa que recursos públicos estão sendo perdidos, provavelmente, com a manutenção de um corpo de funcionários que não está sendo totalmente utilizado". E propunha que a COHAB aumentasse seus 
investimentos, intensificando sua atuação como "provedora efetiva de habitação popular, de estimuladora da atividade da construção civil, etc." ou, se isso não fosse possível, então, que fossem diminuídos seus custos "por meio, por exemplo, da redução do corpo de funcionários e de gastos com instalações até que o custo total fosse adequado à eficiência desejada. Neste caso, os recursos excedentes seriam, então, destinados a outros setores públicos".

Tabela 3.8 - Empreendimentos por empreitada, da COHAB-SP/FMH, com contratos em vigência no final de 2000

\begin{tabular}{|c|c|c|c|c|c|c|c|}
\hline \multirow[b]{2}{*}{ Empreendimento } & \multirow{2}{*}{$\begin{array}{c}\text { Tipo } \\
\text { de } \\
\text { interv. }\end{array}$} & \multicolumn{5}{|c|}{$\begin{array}{l}\text { Nº UH's com contratos em vigência no final de } \\
2000 \text {, com obras em execução ou a iniciar }\end{array}$} & \multirow[b]{2}{*}{ Construtora } \\
\hline & & $\begin{array}{c}\text { total do } \\
\text { conjunto } \\
\text { habit. }\end{array}$ & $\begin{array}{c}\text { entre- } \\
\text { gues até } \\
2000\end{array}$ & $\begin{array}{c}\text { em exe- } \\
\text { cução }\end{array}$ & $\begin{array}{l}\text { sem } \\
\text { OIS }\end{array}$ & \begin{tabular}{|c|} 
entregues \\
a partir de \\
2001
\end{tabular} & \\
\hline Barro Branco II & $E$ & 75 & - & 75 & - & 75 & Ematec Enga \\
\hline Inácio Monteiro & $E$ & 82 & - & 82 & - & 82 & Ematec Enga \\
\hline Irmãos Casimiro (ant.C. Ashcar) & CE & 600 & - & 600 & - & 600 & Paez de Lima Constr. \\
\hline Heliópolis Gleba E & VF & 80 & - & 80 & - & 80 & Construtora ABM \\
\hline Heliópolis Gleba H & VF & 220 & - & 220 & - & - & Basic Engenharia \\
\hline Heliópolis Gleba N & VF & 774 & 344 & 258 & 172 & 430 & Empreend. Master \\
\hline Jd. das Acácias & CE & 600 & - & 140 & 460 & 600 & Sergus Constr. \\
\hline Jd. das Orquídeas & CE & 500 & 340 & 160 & - & 160 & Dall'Acqua Eng. \\
\hline Jd. dos Cedros & CE & 200 & - & 200 & - & 200 & Construtora Yazigi \\
\hline \multicolumn{2}{|l|}{ Total } & 3.131 & 684 & 1.815 & 632 & 2.227 & \\
\hline
\end{tabular}

Fonte: FMH, Acomp. da Execução do Plano de Metas 2001-2004 (1a. Reunião Ordinária do CMH-julho/03)/

COHAB-SP, Relatório de Gestão 2001-2004, 2004/ COHAB-SP, relatórios DITEC, 2002/ CANTERO, 2004

Obs. 1: Tipos de intervenção: E-embriões/ CE-Chamamento Empresarial/VF- Verticalização de Favela

Obs. 2: Heliópolis H não foi concluído, pois sua retomada foi prejudicada, inicialmente, por problemas contratuais com a construtora e por ocupação parcial de sua área pela favela e, posteriormente, por uma ocupação total, inclusive de estruturas já construídas.

Obs. 3: O Jd. das Acácias deixou de ser financiado pelo FMH e foi incluído no programa em parceria com a CDHU. Inicialmente, a CDHU foi refratária à idéia de financiar todo o empreendimento e se cogitou que uma de suas fases recebesse recursos do FMH e outra dessa companhia estadual. Mas depois, vislumbrando-se que haveriam grandes problemas no pós-ocupação, decorrentes do fato de moradores do mesmo conjunto terem contratos de financiamento muito diferentes, por seguirem as regras de cada uma das instituições, houve um consenso de que a CDHU financiaria todo empreendimento. 
No início de 2001, a COHAB-SP tinha sob sua responsabilidade, contratadas com recursos do FMH, 9.242 uh's em obra, boa parte delas paralisadas ou andando em ritmo lento, sendo 6.795 em regime de mutirão com autogestão e $2.447 \mathrm{em}$ regime de empreitada ${ }^{21}$. Dessas últimas, 1815 já haviam recebido OIS (Ordem de Início de Serviços) e 632 ainda não. A maioria pertencia ao Programa Chamamento Empresarial $\mathrm{e}$ as restantes compunham as intervenções de verticalização da favela Heliópolis e embriões em construção em áreas dos conjuntos habitacionais Inácio Monteiro e no Barro Branco. Os empreendimentos executados em regime mutirão estão relacionados no Item 5.3 e os executados por empreitada são listados na Tabela 3.8.

${ }^{21}$ Um estudo sobre os empreendimentos que a COHAB teve em execução na década de 90, boa parte dos quais foram concluídos após 2001, foi feito por CANTERO (2004), que, dentre outros, analisou o Programa Chamamento Empresarial (p. 49) e o empreendimento Heliópolis N (p. 58). 


\section{Capítulo 4:}

\section{O desenho da nova política habitacional}

\subsection{O que se planejou para o período 2001-2004}

Já tendo, no capítulo anterior, abordado as tendências e propostas que faziam parte da bagagem que a nova administração levava para a Prefeitura, neste item, serão relatadas as principais propostas formuladas, já no decorrer da gestão, e observados os momentos mais marcantes em que ocorreu essa formulação.

\subsubsection{O planejamento feito pela COHAB}

Os primeiros desses momentos de formulação de propostas (não em importância, mas em precedência no tempo) foram as reuniões de planejamento estratégico realizadas, separada e/ou conjuntamente, pela SEHAB e pela COHAB. Depois, aconteceu a realização da $1^{\text {a }}$ Conferência Municipal de Habitação, antecedida por um conjunto de pré-conferências.

A posse de Marta Suplicy como prefeita de São Paulo levou à condição de Secretário Municipal de Habitação e Desenvolvimento Urbano o, então, deputado estadual e advogado Luiz Paulo Teixeira Ferreira e de Diretor Presidente da COHAB o arquiteto Jorge Fontes Hereda. Ambos haviam trabalhado na gestão da prefeita Luiza Erundina. Paulo Teixeira como Administrador Regional de São Miguel Paulista e Jorge Hereda como Supervisor de Ação Técnica de HABI, e compuseram equipes com técnicos que, na grande maioria, haviam trabalhado nessa gestão e em gestões do PT em prefeituras da Região Metropolitana de São Paulo.

No início da gestão, em 9 e 10 de fevereiro de 2001, a nova equipe dirigente da COHAB-SP ${ }^{22}$, juntamente com o Secretário Municipal da Habitação e

\footnotetext{
${ }^{22}$ Composta de seu presidente, do chefe de gabinete (arq. Mozart Morais Filho), de seus 6 diretores (geog. Arlete Moisés Rodrigues, Vice-Presidente; psic. Altemir Almeida, Diretor de Patrimônio; arqa ${ }^{\text {. }}$ Maria Cecília Levy P. Fontes, Diretora Comercial e Social; econ. Paulino Caetano, Diretor Administrativo; eng. Ricardo Schumann, Diretor Técnico; econ. Suely Muniz, Diretora Financeira), de 6 assessores da presidência, 5 assessores de diretoria, 7 superintendentes e 1 gerente.
} 
de Desenvolvimento Urbano e do Superintendente de Habitação Popular ${ }^{23}$, realizou a $1^{\text {a }}$ Reunião de Planejamento Estratégico ${ }^{24}$.

Os tempos para a formulação e execução dos programas e projetos habitacionais são longos. Tendo isso em vista, é de se considerar que um dos méritos da nova gestão da SEHAB e da COHAB foi deslanchar esse processo de planejamento logo no início do governo, buscando definir rapidamente linhas de atuação e metas, a divisão de trabalho entre os vários setores, os recursos que se buscaria mobilizar e os prazos a serem perseguidos. Esse processo também teve o mérito de não ficar restrito aos ocupantes dos cargos de confiança. Na COHAB, por exemplo, ocorreram reuniões em todas as diretorias, para as quais foram chamados todos os funcionários, tanto para conhecer as propostas tiradas nas duas reuniões mencionadas (9 e 10/02/2001), quanto para discutir, problematizar, e devolver, com a confirmação ou com questionamentos e novas propostas. O ambiente era favorável a isso.

Nas reuniões de fevereiro de 2001, foram definidos "desafios” a serem enfrentados, "marcas" que se pretendia deixar ao final de 2004 e "resultados" a serem alcançados no final da gestão. Como "desafios" foram colocados os seguintes:

1. "Colaborar com a viabilização da política habitacional do município como braço executor da SEHAB";

2. "Promover a inclusão social das famílias moradoras dos conjuntos habitacionais";

3. "Produzir habitações de qualidade, acessíveis à população de baixa renda de maneira continuada";

4. "Efetivar a atuação da COHAB na região metropolitana";

5. "Recuperar a imagem da Companhia mostrando que ela pode realizar a política habitacional do município";

6. "Promover a modernização administrativa da Companhia".

\footnotetext{
${ }^{23}$ Eng. Ricardo Brandão

24 Nessa reunião e nas seguintes, adotou-se a metodologia do Planejamento Estratégico Situacional, desenvolvida por Carlos Matus, ex-ministro do governo de Salvador Allende, e que encontrou muitos seguidores no Brasil, principalmente, na FUNDAP e em prefeituras petistas do ABC.
} 
Esse conjunto de "desafios" refletia visões e concepções da nova equipe dirigente da Companhia que poderiam ser resumidas da seguinte forma:

- A COHAB tivera, em grande parte de sua história, uma grande autonomia em relação à SEHAB, Secretaria Municipal de Habitação e Desenvolvimento Urbano, com pequena articulação com esse órgão. Autonomia essa proporcionada pelo acesso privilegiado aos recursos do FGTS, que, como apontado anteriormente, tornou-se difícil após a extinção do BNH em 1986 e, praticamente, impossível após a sua (da COHAB) vinculação ao processo de renegociação da dívida feita pela Prefeitura de São Paulo na gestão Pitta.

- Mas, por outro lado, durante as gestões Maluf e Pitta, mesmo com a criação do Fundo Municipal de Habitação (FMH), a COHAB havia sido colocada numa posição secundária na divisão de tarefas para a execução dos programas habitacionais do município. O programa mais importante dessas gestões e que se tornou uma de suas marcas, o Cingapura, havia sido tocado, praticamente, só por $\mathrm{HABI}$ e, nesse período, a COHAB havia concluído a construção de apenas 6.145 uh's (SILVA, 2004, Quadro Resumo).

Toda a autonomia que tivera no passado, a nova equipe dirigente da COHAB nem pretendia que ela voltasse a ter, porque era consensual o entendimento de que Secretaria deveria ser a instância de definição da política habitacional e de suas prioridades. E nem poderia ser diferente, pois a maior fonte de recursos com que a Companhia deveria contar era o $\mathrm{FMH}$, cujos recursos, em sua maior parte, eram provenientes de dotações do orçamento municipal, controladas pela SEHAB. Além do que a COHAB, na hierarquia da PMSP, estava subordinada a essa secretaria. No entanto, pretendia-se que a COHAB voltasse a exercer 0 papel mais importante dentre os órgãos municipais envolvidos com a produção de habitação social, tornando-se o tal "braço executor" da SEHAB.

- O atendimento dado às famílias moradoras de muitos dos conjuntos habitacionais já entregues não havia sido suficiente para que conseguissem melhorias significativas em suas condições de vida. E, inclusive, havia indicações de que a situação de exclusão social em 
que se encontravam até teria se agravado como decorrência das características originais desses conjuntos e da deterioração dessas características ao longo do tempo.

Nessa primeira reunião de planejamento estratégico também foram definidos os resultados que se pretendia alcançar na gestão 2001-2004. Desses resultados, aqueles mais relacionados à construção de novas unidades e à dotação de infra-estrutura urbana e melhoria das condições de habitabilidade em favelas seriam:

- A conclusão de 2500 unidades habitacionais em construção e a construção de mais 2500, com recursos do $\mathrm{FMH}$, com novo padrão de projeto COHAB, num total de 5000 uh's concluídas;

- A construção, em terras da COHAB e com novo padrão de projeto, de 5000 unidades em parceria com a CEF e de 5000 unidades em parceria com a CDHU;

- A construção de 3000 novas unidades por empreiteiras, com novo padrão de projeto e com recursos próprios da COHAB;

- A execução pela COHAB de $100 \%$ das obras do novo programa de habitação do centro de São Paulo, das obras do novo programa de urbanização de favelas e das unidades relacionadas aos contratos que fossem assinados a partir de 2001, no âmbito dos programas PROCAV-PROVER;

- A implementação de um programa de locação social;

- A conclusão de $100 \%$ das 10.000 uh's dos empreendimentos de mutirão com autogestão iniciados na gestão Luiza Erundina, assim como a complementação da infra-estrutura desses empreendimentos e a implantação de equipamentos de uso coletivo;

- A construção de 3000 uh's por mutirão com novo padrão de projeto;

- A informatização de $100 \%$ dos procedimentos relativos à composição de custos, licitação e medição de serviços e obras e a disponibilização pela Internet ao público externo dos dados relativos a esses procedimentos;

- A regularização de $80 \%$ dos conjuntos existentes;

- A complementação e recuperação da infra-estrutura dos conjuntos 
existentes e a adequação dos seus equipamentos;

- A adequação de $100 \%$ dos conjuntos habitacionais existentes às normas de acessibilidade.

Em 26 de março de 2001, em outra reunião de planejamento estratégico, os vários resultados esperados foram agrupados em 3 eixos:

- Eixo 1: "Produzir moradias com qualidade e integradas ao tecido urbano"

- Eixo 2: "Implementar a qualidade de vida nos conjuntos habitacionais" 25

- Eixo 3: "Transformar a COHAB numa empresa eficiente, produtiva e moderna"

O Eixo 1 está mais diretamente relacionado ao objeto desta pesquisa e, portanto, apontamos a seguir os resultados a ele vinculados:

- Conclusão de 2500 unidades e construção de novas 10500 unidades em conjuntos com novo padrão de projeto COHAB, utilizando recursos do $\mathrm{FMH}, \mathrm{CEF}$ e CDHU.

- Conclusão de 10000 unidades e construção de 3000 novas unidades, em regime de mutirão com autogestão, com novo padrão de projeto COHAB.

- Execução de $100 \%$ das obras habitacionais do programa de requalificação do centro e $100 \%$ do novo programa de urbanização de favelas.

- Execução de $100 \%$ das obras dos programas PROCAV, PROVER e Lote Legal.

- Efetivação de parcerias com prefeituras da RMSP.

Nessa mesma reunião (26/03/2001), foram discutidos e agrupados os principais problemas a serem enfrentados na gestão. Um que foi considerado um dos mais importantes (ou mesmo o mais importante) foi a situação econômico-

25 A leitura deste "eixo" tende a levar o leitor a considerar a proposta meio ingênua e/ou meio presunçosa. Mas tendo acompanhado, de certa maneira, a formulação deste eixo, entendemos que houve algum descuido na redação. E que teria se traduzido melhor a intenção que se tinha, se fosse dito: "Melhorar a qualidade de vida dos conjuntos habitacionais". 
financeira da $\mathrm{COHAB}$, que tornava inviável que construísse moradias em número razoável com recursos próprios e sua dependência a recursos externos. Entendendo como recursos externos inclusive aqueles provenientes do Orçamento Municipal, que the fossem aportados como aumento de capital ou investimentos do FMH.

A vislumbrada escassez de recursos deu o tom desde o começo. As metas fixadas foram pensadas mais em função dos recursos esperados, do que do que se poderia supor como necessidade do Município ou como produção histórica da COHAB.

\subsubsection{A $1^{\text {a }}$. Conferência Municipal de Habitação}

A realização de uma Conferência Municipal de Habitação, que possibilitasse a ampla participação e reunião do conjunto dos interessados na política do município para esse setor, era um compromisso que já constava do programa de governo da candidata a prefeita pelo PT, que continha uma série de outras propostas relativas à ampliação dos espaços de participação popular.

Nesse sentido, várias iniciativas foram tomadas ao longo da gestão, dentre elas, a constituição de um setor chamado de participação popular dentro da SEHAB, que teve as funções de: a) ser o primeiro interlocutor com os movimentos organizados que demandavam atendimento; b) organizar vários fóruns, que incluíram as primeiras conferências municipais de Habitação e da Cidade de São Paulo ${ }^{26}$, o Conselho de Representantes eleito na primeira dessas duas conferências; c) organizar a eleição para o Conselho Municipal de Habitação; d) articular a atuação da SEHAB junto ao Orçamento Participativo da PMSP.

\footnotetext{
${ }^{26}$ A Conferência Municipal da Cidade de São Paulo ocorreu em 2003, tratou dos vários assuntos relacionados à questão urbana (transportes, saneamento, desenvolvimento urbano, etc.), além da habitação, e foi organizada por um conjunto de secretarias municipais e entidades da sociedade civil, dentro do processo da Conferência Nacional das Cidades promovido pelo Ministério das Cidades.
} 

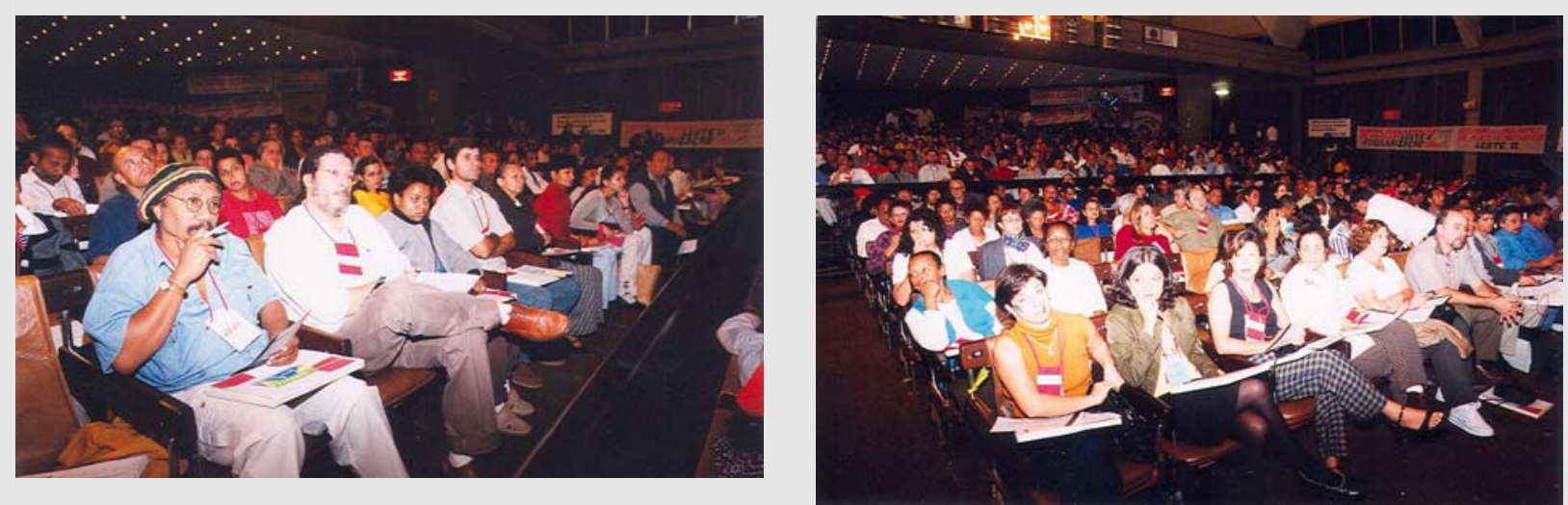

Plenário da $1^{a}$ Conferência Municipal de Habitação - Palácio de Convenções do Anhembi (Fonte: Arquivo COHAB)

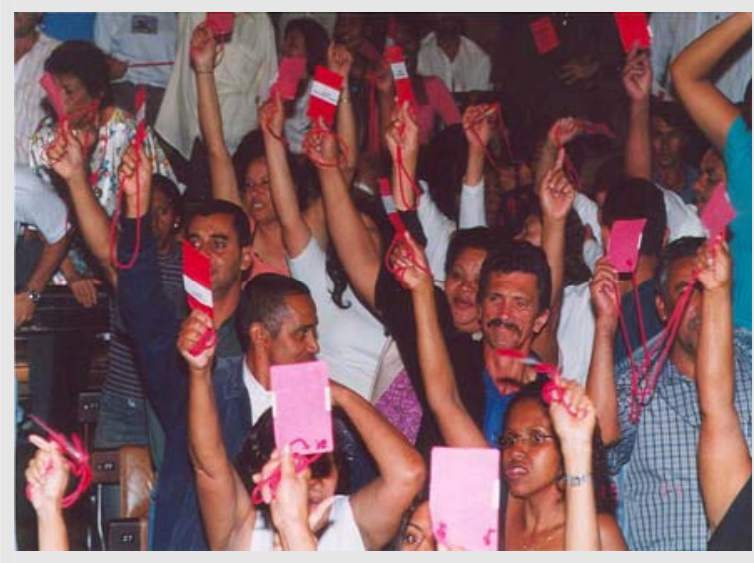

Votação no plenário (Fonte: Arquivo COHAB-SP)

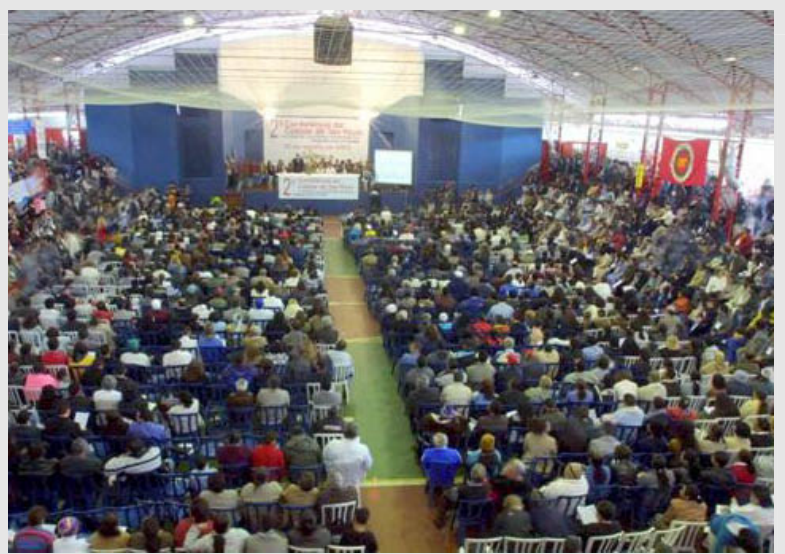

12. Conferência Municipal da Cidade, S. Paulo,

Sindicato dos Bancários, 2003 (Fonte: Arquivo COHAB)

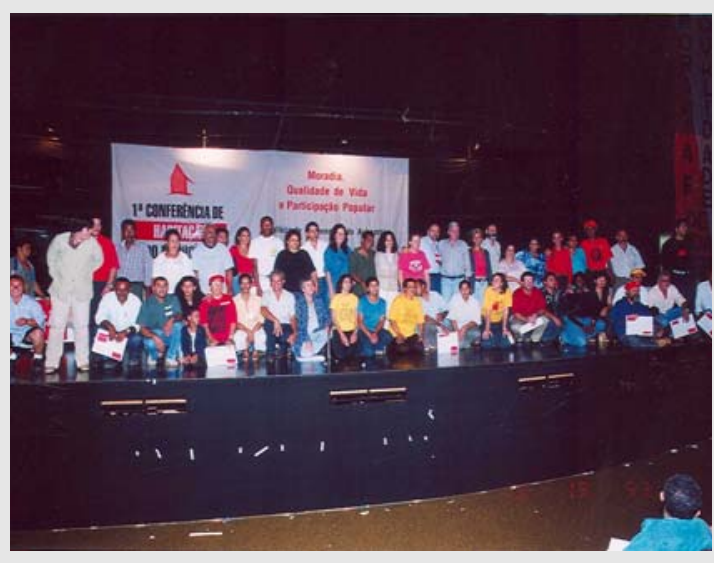

Grupo eleito para o Conselho de Representantes e outros participantes da Conferência (Fonte: Arquivo COHAB-SP)

Esse setor foi formado por lideranças expressivas do movimento popular e por funcionários da Prefeitura e da COHAB com longa experiência em trabalhos com a população. Apesar da relevância do assunto da participação popular na área da habitação e no período estudado (2001-2004), e da sua pertinência em relação ao que está sendo tratado aqui, ele não será objeto de uma abordagem específica por este trabalho. Isso pela sua complexidade, suas várias facetas, que mereceriam toda uma dissertação ou tese 27. Mas, em linhas gerais, abordaremos a $1^{\text {a }}$. Conferência Municipal de Habitação

27 Alguns trabalhos já apresentados discutem a participação popular na área de habitação do Município de São Paulo, no período 2001-2004. Dentre eles: AMARAL (2002), CARVALHO (2004), CAVALCANTI (2006), CYMBALISTA e MOREIRA (2002), FERREIRA (dissertação, 2006, e in: GASPAR, AKERMAN, e GARIBE, 2006), ROSSETTO (2003) e VIEIRA (2005). 
pelo fato de ter sido um momento importante na conformação (e/ou confirmação) das diretrizes que nortearam o planejamento dos trabalhos da SEHAB e da COHABSP, como órgão a ela subordinado.

A 1a. Conferência Municipal de Habitação aconteceu de 7 a 9 de setembro de 2001, no Palácio das Convenções do Anhembi, e "contou com 1.600 delegados, indicados pelas 22.230 pessoas que participaram das 16 pré-conferências regionais" (PMSP/ SEHAB, 2004, p. 10).

A administração levou para a Conferência o documento denominado "Política Municipal de Habitação" em que propunha princípios, diretrizes e ações, descrevia os principais programas que se pretendia implementar e suas metas (PMSP/ SEHAB, 2001). Os princípios e diretrizes e ações eram os seguintes:

\section{“Princípios}

Para enfrentar a precariedade do quadro habitacional da cidade, a administração municipal está desenvolvendo uma política pautada nos seguintes princípios:

- Direito à moradia digna como direito social;

- Intervenção no processo de uso, ocupação e valorização do solo para garantir o acesso democrático à cidade e evitar a exclusão social;

- Participação da sociedade civil na definição, gestão e controle da política habitacional;

- Articulação da política de habitação com as políticas urbanas e sociais, considerando a qualidade da moradia (infra-estrutura, equipamentos sociais e serviços coletivos);

- Prioridade de atendimento para a população de baixa renda, com redistribuição dos recursos públicos e aplicação de subsídios que garantam o acesso à moradia;

- Garantia da permanência nas áreas ocupadas sempre que não implicar risco de vida para os moradores e comprometimento ao meio ambiente;

- Considerar que os problemas habitacionais não se restringem à cidade de São Paulo, mas a toda região metropolitana". 


\section{"Diretrizes e Ações}

As diretrizes e ações que norteiam os programas e projetos que estão sendo implementados são:

- Elaborar em conjunto com os demais municípios um Plano Integrado de Habitação, abrangendo a região metropolitana;

- Criar a Conferência, o Conselho e os Fóruns Regionais de Habitação, com o objetivo de definir e avaliar programas, critérios de hierarquização de projetos e obras;

- Desenvolver uma diversidade de programas adequados às características específicas de cada realidade social e ambiental;

- Propor a criação das Zonas Especiais de Interesse Social (ZEIS);

- Regulamentar instrumentos previstos no Estatuto das Cidades, incentivando a utilização de imóveis vazios, como forma de ampliar a oferta de habitação de interesse social;

- Elaborar e implementar uma política de obtenção de terras e edificações para os programas habitacionais;

- Promover a produção de unidades inseridas na malha urbana, com um novo padrão de projetos;

- Erradicar áreas de risco, requalificar cortiços e urbanizar favelas por meio de ações integradas com todos os órgãos da Prefeitura, do Estado e do governo federal;

- Consolidar a moradia social no centro, em ações conjuntas com movimentos e poderes públicos estadual e federal, contribuindo para o programa de reabilitação da área central e valorização do patrimônio histórico, social e cultural;

- Criar instrumentos de otimização da infra-estrutura e de redução dos custos de urbanização;

- Promover a regularização fundiária dos empreendimentos já consolidados e das unidades construídas;

- Promover a regularização da comercialização dos imóveis construídos com recursos do Fundo Municipal de Habitação e Prover que já se encontram ocupados;

- Promover a construção por mutirões e autogestão como controle social sobre o processo produtivo e barateamento dos custos, além da produção cooperativada; 
- Desenvolver programas de melhoria da qualidade de vida dos moradores dos conjuntos habitacionais já existentes;

- Reformular e elaborar instrumentos de legislação, ocupação e parcelamento do uso do solo, código de obras e edificações que garantam agilidade na aprovação dos empreendimentos - inclusive com a utilização de novas tecnologias, como a Internet - e estabelecer acordos de cooperação técnica entre os órgãos públicos envolvidos, divulgando a legislação de forma acessível para todos os cidadãos;

- Rever a legislação do Fundo Municipal de Habitação, suas atribuições, composição de seu Conselho e as normas de financiamento;

- Implementar subsídio direto, pessoal, intransferível e temporário na aquisição elou locação social;

- Procurar novas fontes de recursos;

- Atuar em conjunto com estado, União e Caixa Econômica Federal para a criação de um Banco de Dados de Uso Compartilhado, com informações de demanda e de oferta de moradias;

- Destinar cotas a idosos e portadores de deficiência nos empreendimentos produzidos e implementar projetos especiais para esses segmentos da população;

- Articular projetos e programas de habitação com as políticas sociais: Bolsa Trabalho, Renda Mínima, Começar de Novo, Oportunidade Solidária e Banco do Povo, bem como a Política de Segurança Múltipla;

- Assegurar o trabalho social na execução e pós-ocupação nos projetos habitacionais com a perspectiva do auto-desenvolvimento das comunidades e difusão de conhecimento;

- Garantir o respeito ao meio ambiente, em conjunto com os demais órgãos da Prefeitura, do Estado e do governo Federal, buscando adotar tecnologias alternativas de conservação de água e energia e de deposição de resíduos sólidos, além da recuperação de áreas verdes e reciclagem dos resíduos inertes dos empreendimentos;

- Avaliar os impactos ambientais, sociais e econômicos dos grandes empreendimentos, em conjunto com os demais órgãos da Prefeitura e do Estado, estudando a possibilidade de compensações;

- Implementar programa de fiscalização e de combate ao surgimento de novos loteamentos irregulares em especial nas áreas de mananciais hídricos e florestais; 
- Participar do processo de revisão da legislação de proteção dos mananciais junto aos Sub-Comitês Billings e Guarapiranga e Alto Tietê e de recuperação do sistema de fiscalização integrado nos mananciais (SOS mananciais);

- Promover a modernização da estrutura administrativa com programas de qualidade e incentivar novos padrões tecnológicos e uso de tecnologias diversificadas;

- Apoiar a formação de técnicos na área de habitação, estabelecendo parcerias com universidades, centros de pesquisa tecnológica, entidades de classe, iniciativa privada e ONG's."

Os programas habitacionais que esse documento apontava eram:

- Provisão Habitacional, que incluía os programas de:

- Mutirões com Autogestão (recursos do FMH),

- Obras empreitadas (recursos do FMH),

- Parceria com a CDHU (recursos do Governo do Estado),

- Arrendamento Residencial -PAR- (recursos da CEF),

- PROVER e PROCAV (ambos com recursos da PMSP e do BID);

- Bairro Legal;

- Guarapiranga/ Alto Tietê;

- Regularização Fundiária;

- Morar Perto;

- Locação Social;

- Viver Melhor;

- Morar Melhor;

- Reabilitação Urbanística.

O desenho desses programas, posteriormente, foi revisto e ganhou contornos mais precisos. Essa sua versão mais bem acabada será descrita no Item 4.2 - Quadro Geral dos Programas.

O documento "Política Municipal de Habitação" também apontou metas numéricas para alguns dos programas. Metas que refletiam as reuniões de Planejamento Estratégico:

1. Construção de 5.000 uh's em parceria com a CDHU e de 5.000 uh's em parceria com a CEF/PAR. 
2. Conclusão, até o final 2002, com recursos do $F M H$, de 7.500 uh's situadas em 47 empreendimentos em regime de mutirão com autogestão, que haviam sido iniciados entre 1989 e 1992 e que haviam ficado paralisados ou semi-paralisados entre 1993 e 2000.

3. Conclusão de 4.660 uh's em regime de empreitada e com recursos do $\mathrm{FMH}$, iniciadas nas gestões anteriores.

4. Conclusão das fases 3 e 4 do Programa de Verticalização de Favelas (PROVER, mais conhecido por Cingapura), que havia sido iniciado na gestão de Paulo Maluf e que tinha, naquele momento, 4 conjuntos em construção ${ }^{28}$. Em relação ao financiamento das obras era informado que a fase 4 contava com recursos do BID (Banco Interamericano de Desenvolvimento) e da Prefeitura.

Na Conferência, no painel sobre Provisão Habitacional, o Diretor Técnico da $C O H A B$, expôs metas um pouco maiores do que as que constavam do documento "Política Municipal de Habitação".

Na Tabela 4.1, serão colocadas as metas que resultaram das reuniões de Planejamento Estratégico feito pela COHAB-SP em 26.03.01, e as que foram apresentadas na Conferência, seja pelo representante da COHAB no painel, seja no mencionado documento.

28 Jd. Imperador (380 uh's), Jd. do Lago (124 uh's), Heliópolis Gleba A (60 uh's), S. Francisco Área 6 (280 uh's). 
Tabela 4.1 - Metas definidas para COHAB em 2001

\begin{tabular}{|c|c|c|c|}
\hline $\begin{array}{l}\text { Programas previstos para serem } \\
\text { executados pela COHAB }\end{array}$ & $\begin{array}{l}\text { Planejam. } \\
\text { Estratégico } \\
\text { COHAB - } \\
26.03 .01\end{array}$ & $\begin{array}{l}\text { Exposição } \\
\text { COHAB }-1^{\mathrm{a}} \text {. } \\
\text { Conf. Mun. } \\
\text { Hab. - set/01 }\end{array}$ & $\begin{array}{c}\text { Política } \\
\text { Municipal de } \\
\text { Habitação }-1^{\text {a }} \text {. } \\
\text { Conf. Mun. Hab }\end{array}$ \\
\hline $\begin{array}{l}\text { 1. Construção de conjuntos habitacionais } \\
\text { em parceria com a CDHU }\end{array}$ & 5.000 uh's & 5.000 uh's & 5.000 uh's \\
\hline $\begin{array}{l}\text { 2. Construção de conjuntos habitacionais } \\
\text { em parceria com a CEF/PAR. }\end{array}$ & 5.500 uh's & 5.000 uh's & 5.000 uh's \\
\hline $\begin{array}{l}\text { 3. Conclusão de mutirões iniciados entre } \\
89 \text { e } 92 \text {, com recursos do FMH. }\end{array}$ & 10.000 uh's & 7.755 uh's & 7.500 uh's \\
\hline $\begin{array}{l}\text { 4. Construção de novos } \\
\text { empreendimentos por mutirão com } \\
\text { recursos do FMH }\end{array}$ & 3000 uh's & 4.245 uh's & (.............. \\
\hline $\begin{array}{l}\text { 5. Construção de } \mathrm{CH} \text { 's por empreitada p/ } \\
\text { demanda de favelas, etc., com } \\
\text { recursos do FMH }\end{array}$ & .............. & 4.800 uh's & (............... \\
\hline $\begin{array}{l}\text { 6. Conclusão obras empreitadas com } \\
\text { recursos do FMH, iniciadas nas } \\
\text { gestões anteriores. }\end{array}$ & 2500 uh's & 2389 uh's & 4.660 uh's \\
\hline $\begin{array}{l}\text { 7. Execução das obras habitacionais do } \\
\text { programa de requalificação do centro. }\end{array}$ & $100 \%$ & (............... & (.............. \\
\hline $\begin{array}{l}\text { 8. Execução das obras do novo programa } \\
\text { de urbanização de favelas. }\end{array}$ & $100 \%$ & ……............. & ..................... \\
\hline $\begin{array}{l}\text { 9. Execução das obras dos programas } \\
\text { PROCAV, PROVER e Lote Legal. }\end{array}$ & $100 \%$ & ……............. & ……............ \\
\hline Total de uh's já previstas à época & 26.000 uh's & 29.189 uh's & 22.160 uh's \\
\hline
\end{tabular}

Fontes: COHAB-SP, "Relatórios do Planejamento Estratégico", 2001; Slides da exposição da COHAB na $1^{a}$. Conferência Municipal de Habitação, 2001; SEHAB, "Política Municipal de Habitação", 2001

No quadro verificam-se várias discrepâncias, que são causadas por: a) diferentes estágios de levantamento da situação das obras e contratos em andamento; b) por não estarem, à época, ainda muito consolidadas as idéias sobre o que deveria estar contido em cada programa ou tipo de intervenção; e c) por previsões mais ou menos otimistas sobre os recursos que se disporia.

Posteriormente, verificou-se que eram diferentes os números relativos ao conjunto de obras financiadas com recursos do $\mathrm{FMH}$, que haviam sido deixadas pelas gestões anteriores sem que fossem concluídas: 6.795 uh's em regime de mutirão com autogestão e 2.447 uh's em regime de empreitada. As razões das discrepâncias apontadas acima (itens $\mathbf{a}, \mathbf{b}, \mathbf{c}$ ) podem explicar também essas alterações. No programa de mutirões, houve uma mudança na forma de entender o que seriam obras antigas (iniciadas entre 89 e 92) a serem concluídas, e novas etapas de convênios antigos. Os convênios antigos previam novas etapas de obras 
ainda não iniciadas (950 uh's). Com a soma do número de unidades dessas etapas às 6.795 já em andamento que necessitavam ser concluídas, chegava-se a 7.745 uh's, número próximo ao apresentado pela COHAB no painel sobre Provisão (7.755 uh's)

A COHAB, inicialmente, havia pleiteado ficar como responsável pela execução das obras habitacionais do programa de requalificação do centro (Morar no Centro), do novo programa de urbanização de favelas, do PROCAV, do PROVER e do Lote Legal. Pois havia um entendimento dentro da Companhia de que possuía uma estrutura que seria muito grande para apenas tocar o conjunto de obras que se esperava do FMH (mutirões e obras por empreiteira para atendimento a remoções de favelas). E, para que não houvesse ociosidade, poderia executar obras (pelo menos, em parte) desses outros programas, que estavam sendo acompanhadas por um pequeno corpo de funcionários da SEHAB, assessorados por gerenciadoras.

As informações sobre o desenvolvimento do conjunto dos programas mencionados, obtidas pela pesquisa que é resumida por esta dissertação, não são suficientes para permitir que se afirme se houve acerto ou equívoco na divisão de trabalho adotada. Mas o que se pode entrever, a partir de uma rápida observação, é que a $\mathrm{COHAB}$ teria dificuldade de tocar todos os programas que foram pleiteados, juntamente com aqueles que Ihe foram destinados através do $\mathrm{FMH}$.

Dos programas pleiteados, ficaram sob responsabilidade da COHAB as obras apenas do Morar no Centro. As obras do novo programa de urbanização de favelas, do PROCAV e do PROVER ficaram como atribuição de HABI e as do Lote Legal como atribuição de RESOLO.

As discussões que aconteceram na $1^{\mathrm{a}}$. Conferência não indicaram grandes divergências em relação ao que foi proposto pela SEHAB. Mas em torno de um ponto houve, sim, grande discordância, que ocasionou grande tensionamento entre parcela dos movimentos populares e a administração. Esse tensionamento, no seu ápice, motivou o abandono do plenário por, aproximadamente, metade dos participantes, que sinalizavam com a intenção de abandonar inclusive a conferência.

Um esforço de distensão feito por muitas lideranças, levou os movimentos que haviam abandonado o plenário a reconsiderar sua decisão e a continuar 
participando da conferência. A questão que motivou toda celeuma foi sobre a destinação de terras da COHAB-SP para o PAR e para o programa em parceira com a CDHU. Grande maioria dos movimentos, inclusive aqueles que permaneceram no plenário, eram favoráveis a uma ampla priorização do Programa de Mutirões, na destinação dessas terras. No esforço de conciliação, foi fundamental o papel de lideranças de movimentos que haviam sido (ou pretendiam ser) atendidos pelo PAR, no centro da cidade.

A justificativa apresentada pelos representantes da Prefeitura foi a de que ela não teria recursos para financiar, através do $\mathrm{FMH}$, tantas moradias por mutirão quanto era o número de uh's que poderiam ser construídas nessas terras. E que não havia sentido em manter terras ociosas e em se recusar recursos da CEF/PAR e da CDHU, destinados também a famílias de baixa renda. Se bem que, pelo PAR, fossem atendidas famílias entre 4 e 6 salários mínimos, uma faixa de renda superior àquela que poderia ser atendida pelo $\mathrm{FMH}$.

Um outro ponto também gerou uma grande polêmica: a proposta feita por movimentos de que $5 \%$ do Orçamento do Município fosse vinculado a habitação. Os representantes da administração, em peso, manifestaram-se contrários a essa vinculação, seguindo uma posição que seria mais do interesse geral do Governo Municipal (evitar mais uma vinculação de receita, como as que já existiam para a educação (30 e $25 \%$ ) e saúde (15\%)), do que do interesse específico da SEHAB e da $\mathrm{COHAB}$, para as quais seria importante contar com recursos em montantes maiores e com desembolsos mais regulares.

Além de uma preocupação em não prejudicar, com mais uma vinculação de receita, a situação geral das finanças da Prefeitura, cuja gravidade ainda não era de todo conhecida, havia também, dentre os representantes do Executivo Municipal na Conferência, uma preocupação de que não fosse possível uma utilização plena dos recursos que viessem a ser recebidos por conta dessa vinculação. Isso porque havia dúvidas sobre a capacidade operacional instalada (na SEHAB e na COHAB) e os prazos nada curtos impostos pelas legislações, mas também pelos procedimentos normais de trabalho, relacionados às atividades de desapropriação ou outras formas de aquisição de terras, de licitação, contratação e execução de projetos e obras, e de licenciamento de obras. 
A $1^{\text {a }}$. Conferência Municipal de Habitação aprovou a vinculação de $5 \%{ }^{29}$. Mas que não foi aplicada na elaboração dos orçamentos municipais nos anos subseqüentes.

${ }^{29}$ AMARAL, 2002, p. 72; CAVALCANTI, 2006, p. 118 


\subsection{Quadro geral dos programas}

O conjunto das atribuições da SEHAB pode ser reunido em dois grandes blocos: o de licenciamento do uso e ocupação do solo e o de habitação de interesse social, que envolve a produção de moradias, urbanização e regularização de favelas e loteamentos irregulares. Talvez essa secretaria seja, dentre todas as do município, aquela que lida com as questões mais paradoxais: de um lado aprova os edifícios de luxo, shopping centers, mega-empreendimentos e de outro atende a moradores de favelas, cortiços, dos baixos de viadutos, etc. Encontram-se, a todo momento, nos mesmos corredores e salas do Edifício Martinelli ${ }^{30}$, a "cidade legal" e a "cidade real"; o SECOVI ${ }^{31}$ e os representantes de moradores de rua, favelas e cortiços (MARICATO, 1997).

É muito grande o conjunto de programas desenvolvidos pela SEHAB e pela COHAB voltados à habitação social. Para quem o observa pela primeira vez, tende a parecer um cipoal, um grande emaranhado.

No geral, esses programas refletem a diversidade de soluções que é necessária para o equacionamento dos problemas de moradia. Mas em alguns casos, refletem a presença de outra ordem de fatores, que, geralmente, conflitam com idéias de uma maior racionalidade na organização da máquina administrativa: ingerências políticas; intenção de proporcionar cargos a determinados funcionários; ou o atendimento a requisitos colocados por bancos dos quais que se tomou financiamento, que, muitas vezes, exigem a criação de organismos de gestão específicos, etc.

Depois de criadas estruturas para tocar determinados programas, tornase difícil desmontá-las, mesmo quando sua existência passa a ser desfavorável à racionalização do trabalho e mesmo quando assumem novos gestores com idéia de mudá-las. Isso porque têm grande capacidade de perpetuação, pois, com o tempo, vão surgindo amarrações, tais como: contratos com fornecedores externos, dotações de recursos vinculadas por lei ou por contratos de financiamento, equipes

\footnotetext{
30 Onde a SEHAB está sediada.

${ }^{31}$ Sindicato das Empresas de Compra, Venda, Locação e Administração de Imóveis Residenciais e Comerciais de São Paulo.
} 
montadas, treinadas e que desenvolveram procedimentos, conhecimentos e culturas específicas.

Esse (aparente ou real) emaranhado amplia as dificuldades que são próprias a todas as organizações: as definições de quem faz o quê, quem ficará com quais recursos (financeiros, humanos, etc.), quem será cliente e fornecedor de quem. A CDHU que lida com problemas, em alguns aspectos semelhantes, mas, noutros não tão amplos quanto os da SEHAB e da COHAB (pois, entre outras coisas, não tem que cuidar de emergências, como incêndios em baixos de viadutos, desmoronamentos em favelas, etc.) contou por dois anos com a consultoria da GVConsult, em um trabalho de revisão de processos, etc. Ou seja, estamos falando de problemas que estão na esfera do que tem sido tratado pelas ferramentas da Revisão de Processos ou Reegenharia.

Dentro da estrutura da SEHAB e da COHAB, foram desenvolvidos trabalhos na linha da melhoria dos processos. Cabe lembrar da Certificação pela ISO 9001:2000, obtida pela Gerência de Projetos da COHAB-SP. Mas os problemas que se enfrenta nesse campo continuam a ter dimensões consideráveis.

É importante lembrar que se verificou uma notável, capacidade das estruturas existentes e de seus funcionários para equacionar os novos problemas que se colocavam, para destrinchar os novos programas que eram propostos (alojamento em hotéis, projetos para reformas, bolsa-aluguel, etc.). Essa flexibilidade é desejável. Mas que não se entenda como um elogio à improvisação, ao descuido com a definição de procedimentos claros, e uma oposição à padronização, etc. É uma capacidade de criar o procedimento "no fazer". É não ser refratário a novos programas e propostas porque "nunca se fez antes". Alguns órgãos e empresas públicas perdem essa flexibilidade, ficam enrijecidos e avessos ao enfrentamento de problemas tais como se colocam, insistindo em encaixar os problemas novos (e mesmo aqueles nada novos) nas soluções de sempre.

Nas Tabelas 4.2 e 4.3, são indicados os setores responsáveis pela execução dos programas e o números de famílias atendidas. 
Tabela 4.2 - Matriz dos Programas executados pela SEHAB e COHAB-SP, no período 2001-2004

\section{Nas células são indicados os agentes responsáveis pela execução}

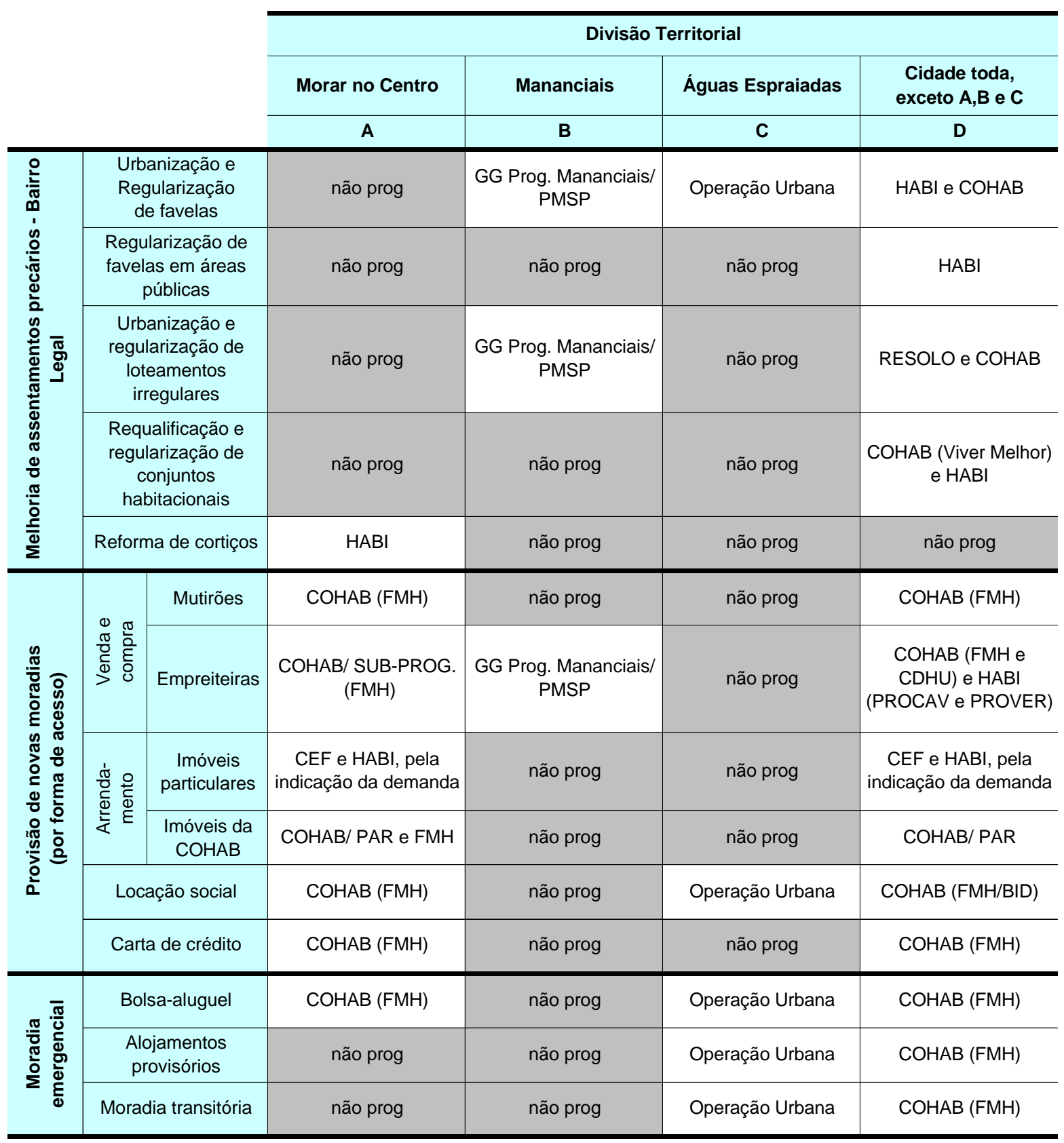

"não prog." indica que não que não há previsão e "nd." que não se obteve informações relativas a esse tipo de atuação.

Fonte: Elaboração do autor, com colaboração de Maria Lúcia D'Alessandro 
Tabela 4.3 Matriz dos Programas executados pela SEHAB e COHAB-SP, no período 2001-2004 -
nas células são indicados os números de famílias atendidas

\begin{tabular}{|c|c|c|c|c|c|c|c|c|c|c|c|c|}
\hline & & \multicolumn{10}{|c|}{ 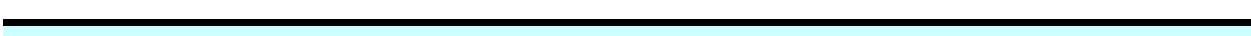 } \\
\hline & & & & & & & Divi & ío Territ & & & & \\
\hline & & & \multicolumn{2}{|c|}{ Morar no Centro } & \multicolumn{2}{|c|}{ Mananciais } & \multicolumn{2}{|c|}{$\begin{array}{l}\text { Operações } \\
\text { Urbanas }\end{array}$} & \multicolumn{2}{|c|}{$\begin{array}{l}\text { cidade toda, } \\
\text { exceto } A, B \text { e } C\end{array}$} & \multicolumn{2}{|c|}{ Total } \\
\hline & & & term. & viab. & term. & viab. & term. & viab. & term. & viab. & term. & viab. \\
\hline \multirow{5}{*}{ 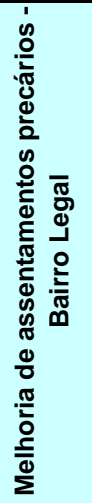 } & & $\begin{array}{c}\text { Urbanização e } \\
\text { Regularização } \\
\text { de favelas }\end{array}$ & \multicolumn{2}{|c|}{ não prog } & 55 & 10.083 & 0 & 1.515 & 0 & 68421 & 55 & 80.019 \\
\hline & \multicolumn{2}{|c|}{$\begin{array}{l}\text { Regularização de favelas } \\
\text { em áreas públicas }\end{array}$} & \multicolumn{2}{|c|}{ não prog } & \multicolumn{2}{|c|}{ não prog } & \multicolumn{2}{|c|}{ não prog } & 45.856 & 45.856 & 45.856 & 45.856 \\
\hline & \multicolumn{2}{|c|}{$\begin{array}{c}\text { Urbanização e regularização } \\
\text { de loteamentos irregulares }\end{array}$} & \multicolumn{2}{|c|}{ não prog } & 0 & nd & \multicolumn{2}{|c|}{ não prog } & 63.587 & 77.452 & 63.587 & 77.452 \\
\hline & \multicolumn{2}{|c|}{$\begin{array}{c}\text { Requalificação e } \\
\text { regularização de conjuntos } \\
\text { habitacionais }\end{array}$} & \multicolumn{2}{|c|}{ não prog } & \multicolumn{2}{|c|}{ não prog } & \multicolumn{2}{|c|}{ não prog } & 778 & 778 & 778 & 778 \\
\hline & \multicolumn{2}{|c|}{ Reforma de cortiços } & 0 & 0 & \multicolumn{2}{|c|}{ não prog } & \multicolumn{2}{|c|}{ não prog } & 0 & 0 & 0 & 0 \\
\hline \multirow{6}{*}{ 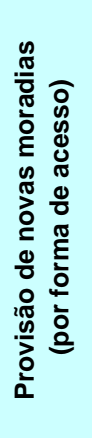 } & \multirow{2}{*}{ 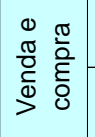 } & Mutirões & 182 & 182 & \multicolumn{2}{|c|}{ não prog } & \multicolumn{2}{|c|}{ não prog } & 7.447 & 13.744 & 7.447 & 13.744 \\
\hline & & Empreiteiras & 68 & 120 & 51 & 51 & \multicolumn{2}{|c|}{ não prog } & 6.934 & 12.138 & 7.053 & 12.309 \\
\hline & \multirow{2}{*}{ 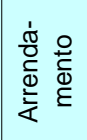 } & Imóveis particulares & 503 & 503 & \multicolumn{2}{|c|}{ não prog } & \multicolumn{2}{|c|}{ não prog } & \multicolumn{2}{|c|}{ nd } & 503 & 503 \\
\hline & & Imóveis da COHAB & 0 & 527 & & prog & & orog & 1.260 & 4.135 & 1.260 & 4.662 \\
\hline & & Locação social & 623 & 2.150 & & prog & & orog & & orog & 623 & 2.150 \\
\hline & & Carta de crédito & 0 & 0 & & prog & & orog & 0 & 0 & 0 & 0 \\
\hline డె & & Bolsa-aluguel & 2.600 & 2.600 & & prog & & orog & 0 & 0 & 2.600 & 2.600 \\
\hline ) & Aloj & jamentos provisórios & nãc & orog & & prog & & orog & nd & nd & nd & nd \\
\hline & & Moradia transitória & nãc & orog & & prog & & orog & 100 & 100 & 100 & 100 \\
\hline & & Total & 3.976 & 6.082 & 106 & 10.134 & 0 & 1.515 & 125.962 & 222.624 & 129.862 & 240.173 \\
\hline
\end{tabular}

Fonte: Elaboração do autor, com colaboração de Maria Lúcia D'Alessandro

Obs. "term." indica obras e atendimentos concluídos até o final de 2004 e "viab." indica obras e atendimentos viabilizados até o final de 2004. Entendendo como viabilizado aqueles cujas principais condições para serem executados já estavam garantidas, ou seja, dispunham de terra, projeto e recursos.

"não prog." indica que não que não há previsão e "nd." que não se obteve informações relativas a esse tipo de atuação. 
Nesta matriz, pode-se ver que foram desenvolvidos 3 grandes blocos de programa (indicados nas linhas): "Urbanização e regularização de assentamentos precários", "Provisão de novas moradias", "Atendimento com moradias provisórias".

Os programas reunidos no bloco da "Urbanização e regularização de assentamentos precários" recebeu uma grande ênfase. Justificada pelo entendimento de que são muitos numerosos os assentamentos precários, de que as intervenções que visam promover melhorias (urbanização e regularização) têm custo muito menor do que a produção de unidades novas, permitem que se preserve um conjunto de relações, de redes que as famílias estabelecem em seu lugar de moradia (proximidade à familia e amigos, proximidade a locais de trabalho e de prestação de serviços, tais como creches e escolas dos filhos), de que, mesmo nesses assentamentos precários, muito investimento já foi feito e pode ser aproveitado (casas construídas em alvenaria muitas vezes com áreas superiores às oferecidas pelos programas de provisão, infra-estrutura parcial, mas já existente, etc.). É evidente que não se propunha a manutenção de favelas e loteamentos que estivessem implantados em áreas sujeitas a riscos geotécnicos, de inundação e de incêndio (com muitas construções em madeira).

Em 2001, entendimentos entre os principais dirigentes da SEHAB e da COHAB-SP e uma reunião de Planejamento Estratégico redefiniram os papéis dos órgãos subordinados a essa Secretaria e envolvidos diretamente com habitação de interesse social (HABI, RESOLO ${ }^{32}$, Programa Mananciais e a própria COHAB).

Essa redefinição era crucial porque havia grande superposição de atribuições. Por exemplo: a HABI era responsável pelas obras do PROVER ${ }^{33}$, mas a COHAB executava algumas obras de verticalização em favelas que não pertenciam a esse programa, como era o caso das Glebas E, H e N de Heliópolis e que, inclusive, eram vizinhas da Gleba A, integrante do PROVER. Nesse caso, a linha de corte era estabelecida pela fonte de financiamento. Ficavam para HABI os empreendimentos com financiamento do BID (Banco Interamericano de Desenvolvimento) e para a COHAB aqueles financiados pelo $\mathrm{FMH}$.

\footnotetext{
32 Departamento de Regularização do Parcelamento do Solo.

33 Programa de Verticalização e Urbanização de Favelas.
} 
O Programa Mananciais, que sucedeu ao Programa Guarapiranga, também cuidava da regularização e urbanização de favelas como $\mathrm{HABI}$ e havia construído conjuntos habitacionais como a COHAB e HABI. Para este programa o que estabelecia o limite de sua atuação era o território das bacias hidrográficas, que contribuíam para a Represa Guarapiranga e estavam dentro do Município de S. Paulo.

O RESOLO atuava na regularização e urbanização de loteamentos irregulares, mas, nessa mesma situação, estavam alguns parcelamentos que haviam surgido irregularmente em terras da $\mathrm{COHAB}$, e em relação aos quais havia um trabalho dessa Companhia visando a regularização. Esse era o caso do Jardim da Conquista, Jardim Continental, Gleba Pêssego-Carmo, que, juntamente, com a Gleba K da Favela Heliópolis, tinham sido objeto de ações do Ministério Público e com o qual, numa tentativa de equacionamento, a COHAB havia firmado Termos de Ajuste de Conduta (TAC's), nas gestões anteriores a $2001^{34}$.

Então, após a mencionada redefinição de tarefas que ocorreu em 2001, para HABI ficaram todas as intervenções no interior de favelas, exceto aquelas contidas na área de abrangência do Programa Guarapiranga, e as que eram objeto de antigos contratos da COHAB dentro de Heliópolis. Contratos esses cuja transferência para HABI, não parecia possível, mas, ainda que fosse, com certeza demandaria um imenso trabalho. Mas em relação às intervenções em Heliópolis , ficou definido que todos os novos projetos, inclusive, aqueles para as Glebas $\mathrm{A}, \mathrm{K} \mathrm{e}$ $\mathrm{N}$, seriam executados por HABI. Dessa forma, para HABI coube a continuidade dos empreendimentos do PROVER/Cingapura e os vinculados ao PROCAV ${ }^{35}$, já incluídos em contratos de financiamento firmados com o BID (Banco Interamericano de Desenvolvimento). E iniciar um novo programa de urbanização e regularização de favelas, que tinha como objetivo a inserção da favela na malha urbana por meio de ações de melhoria das condições de habitabilidade, infra-estrutura e saneamento.

\footnotetext{
34 Estimava-se que, nessas glebas, houvesse 19. 049 unidades habitacionais, sendo 7.000 no Jardim da Conquista, 5.000 no Jardim Continental, 1.149 na Gleba Pêssego-Carmo, e 5.900 na Gleba K da Favela Heliópolis.

35 Programa de Canalização de Córregos, Implantação de Vias e Recuperação Ambiental e Social de Fundos de Vale, que é encabeçado pela Secretaria de Infra-Estrutura Urbana e com o qual a SEHAB contribui com a remoção de favelas.
} 
Em função dessas definições, a proposta que a COHAB fizera desde 0 começo da gestão de executar as obras do PROVER, do PROCAV e do novo programa de ação em favelas não se efetivou. As explicações que foram dadas para isso foram: a) a HABI tinha maior experiência nos trabalhos relativos às favelas -o que era real- ; b) haviam muitas amarrações em torno dos contratos do PROVER e do PROCAV que dificultariam, se é que não impediriam sua transferência para a $\mathrm{COHAB}$; c) as dotações do Orçamento Programa aprovado na gestão anterior (Pitta) para 2001 destinavam a HABI, os recursos necessários para esses programas, e haveria dificuldades para que fossem transferidos para a COHAB, fosse através do $\mathrm{FMH}$, fosse pela contratação da $\mathrm{COHAB}{ }^{36}$.

No período 2001-2004, o PROVER executou 2.180 uh's e o PROCAV 2.837 uh's, das quais entregou $2.197^{37}$. O novo Plano de Ação em Favelas envolveu a elaboração de projetos para 30 núcleos de favelas ${ }^{38}$, em que, segundo se estimava, residiam 68.421 famílias ${ }^{39}$. Os projetos foram elaborados entre 2001 e 2004 e, ao final de 2004 já estavam concluídas as licitações das obras de 14 favelas e o início das obras dependia apenas da iminente transferência de recursos, da ordem de R\$ 25 milhões (fonte Habi 3), já contratados com o Ministério das Cidades. As obras dessas favelas foram iniciadas na gestão José Serra, com pequenas alterações nos projetos.

Também foi desenvolvido por HABI um Programa de Regularização de Favelas situadas em áreas públicas, cujo objetivo era a regularização jurídica e registrária das favelas de forma a inseri-las no contexto legal da cidade. Esta ação foi possível por meio da utilização da Medida Provisória 2220/2001 que possibilita a outorga da Concessão de Uso Especial para Fins de Moradia, para moradores de

36 A COHAB foi contratada pela SEHAB e/ou diretamente por alguns dos órgãos a ela subordinados para a prestação de serviços específicos, como, por exemplo, gerenciamento de parcela das obras de $\mathrm{HABI}$, na gestão Erundina; para regularização de conjuntos do PROVER e para produção de plantas AU do Lote Legal, na gestão Pitta. Cogitou-se que, de forma semelhante, fosse contratada pela SEHAB para executar obras do PROVER, PROCAV e do novo programa de ação em favelas.

37 PMSP/ SEHAB, "Balanço Qualitativo de Gestão 2001-2004".

38 O número de 29 favelas foi obtido no "Balanço Qualitativo de Gestão 2001-2004" e a ele foi adicionado número referente à favela Elisa Maria, que havia sido omitida, involuntariamente.

39 De forma semelhante ao mencionado acima, ao número de famílias obtido no "Balanço Qualitativo de Gestão 2001-2004", foi adicionado o número de famílias referente à favela Elisa Maria, obtido em HABI 3. 
favelas localizadas em áreas de uso comum do povo, obedecidas as condições estabelecidas pela Lei.(áreas ocupadas por prazo igual ou superior a 5 anos, com dimensão igual ou superior a $250 \mathrm{~m}^{2}$, utilizada para fins residenciais ou não, cujo ocupante não seja proprietário ou cessionário de outro imóvel. Esse programa beneficiou 45.856 famílias (PMSP/ SEHAB, "Balanço Qualitativo de Gestão 20012004").

A prioridade para regularização e urbanização de favelas, com o maior aproveitamento do seu tecido, das edificações existentes no assentamento, com a construção de novas unidades habitacionais apenas onde fosse mais necessário, era uma das idéias básicas da gestão. Tal prioridade concordava com o ideário da gestão anterior do PT na Capital e de grande parte (ou de todas) as suas administrações em outras cidades e conflitava com aquele do Programa Cingapura, das gestões Maluf e Pitta, cuja opção havia sido a construção de edifícios onde existiam favelas, que eram removidas/erradicadas, muitas vezes, apenas parcialmente e em suas áreas de maior visibilidade (voltadas para grandes avenidas).

Alguns trabalhos estudam essas formas alternativas de conceber a atuação em favelas e suas diferenças. Sobre o Cingapura cabe citar a dissertação de Sylvia Ammar FORATO. E, sobre as concepções que buscam um maior aproveitamento do tecido existente na favela, os estudos de Maria Lúcia D’ALESSANDRO (1999), Laura BUENO (2000) e Rosana DENALDI (2003). Uma discussão importante sobre o impacto positivo das intervenções em favelas e a melhoria das suas condições sanitárias é desenvolvida na dissertação de Renata FURIGO (2003). Sobre as intervenções promovidas pela SEHAB e pela COHAB, na maior favela da cidade de São Paulo, Heliópolis, há a dissertação de Maria Cecília L. P. FONTES (2005).

Nessa divisão de tarefas, ao RESOLO coube os programas de complementação de infra-estrutura urbana e regularização de loteamentos irregulares denominados "Lote Legal" e o "Bem Legal". O Lote Legal visava a regularização urbanística e jurídica, foi financiado em parte BID, vinculava-se ao Programa Bairro Legal, tinha como foco, principalmente, os loteamentos com grandes dimensões e localizados, preferencialmente, em distritos da cidade com alto 
índice de exclusão. Esse programa abrangeu 69 loteamentos e atendeu a 21.768 famílias (PMSP/ SEHAB, "Balanço Qualitativo de Gestão 2001-2004"). O Bem Legal visa a regularização urbanística e registrária de loteamentos, em uma ação conjunta do Resolo com as comunidades organizadas demandatárias, a partir dos 3100 processos que tramitavam na época no Resolo.

O Programa de Mananciais responde pelas ações de urbanização e regularização de favelas e loteamentos, tendo como objetivo a adequação da infraestrutura urbana e de saneamento, visando à melhoria e conservação da qualidade da água dos reservatórios, bem como das condições de vida da população moradora. Atua nas áreas das bacias dos principais reservatórios que abastecem São Paulo. Inicialmente focado na Represa Guarapiranga, passou a incluir a Represa Billings e, dessa forma, teve seu nome mudado de Programa Guarapiranga para Mananciais. Entre 2001 e 2004, atendeu a 55 favelas, com 10.083 famílias (PMSP/ SEHAB, "Balanço Qualitativo de Gestão 2001-2004").

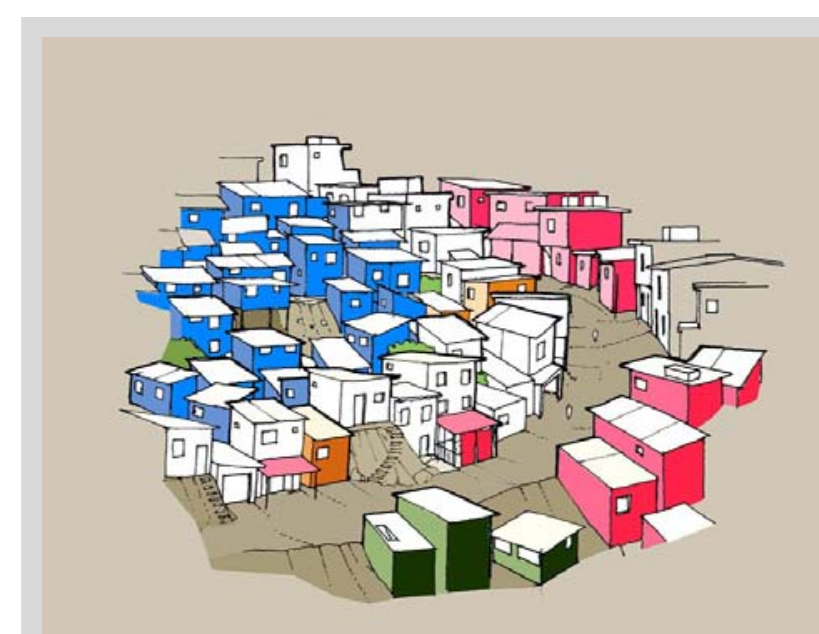

Fav. Jaguaré - desenho esquemático da situação atual

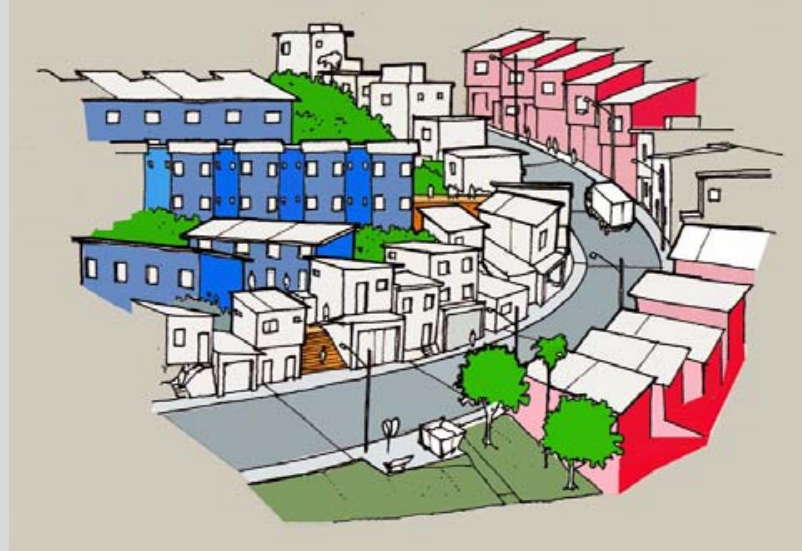

Fav. Jaguaré - desenho esquemático da situação futura 

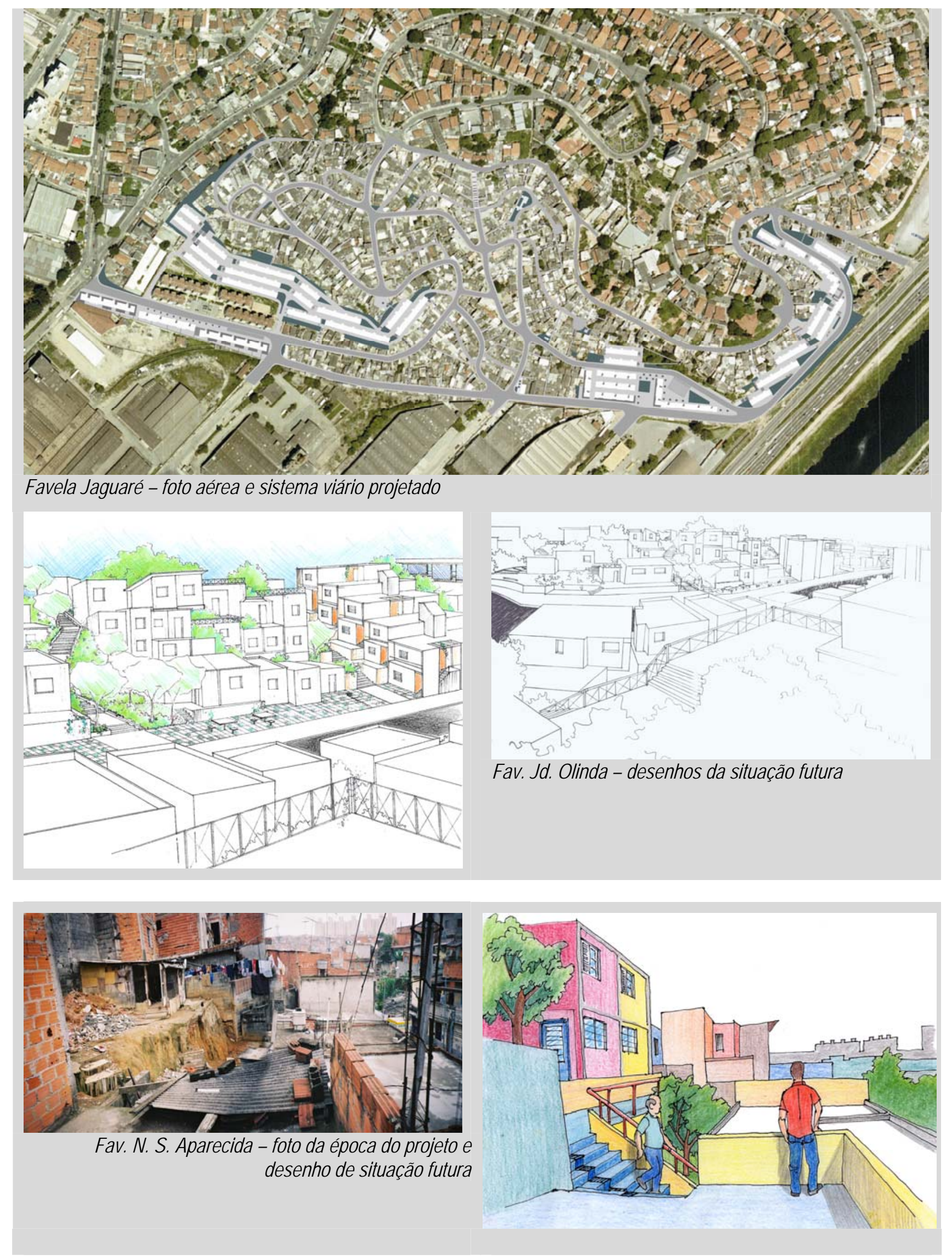


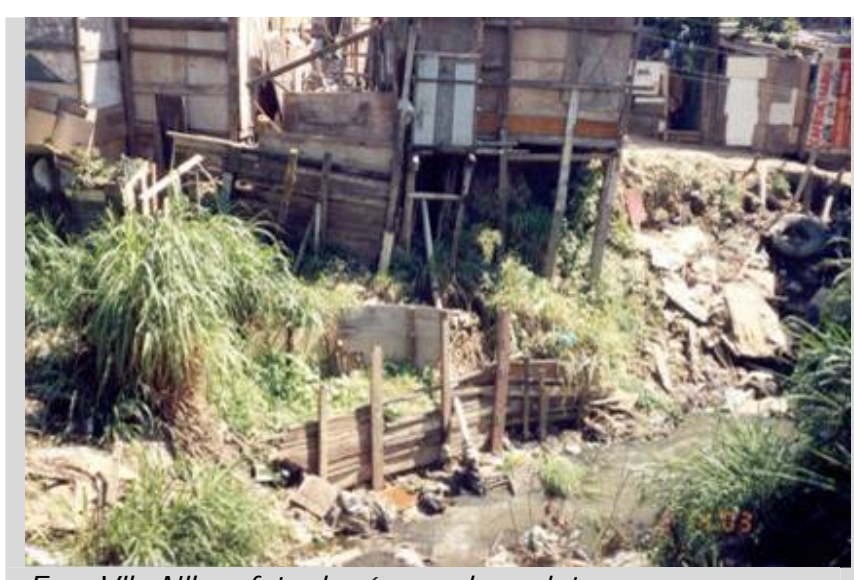

Fav. Vila Nilo - foto da época do projeto

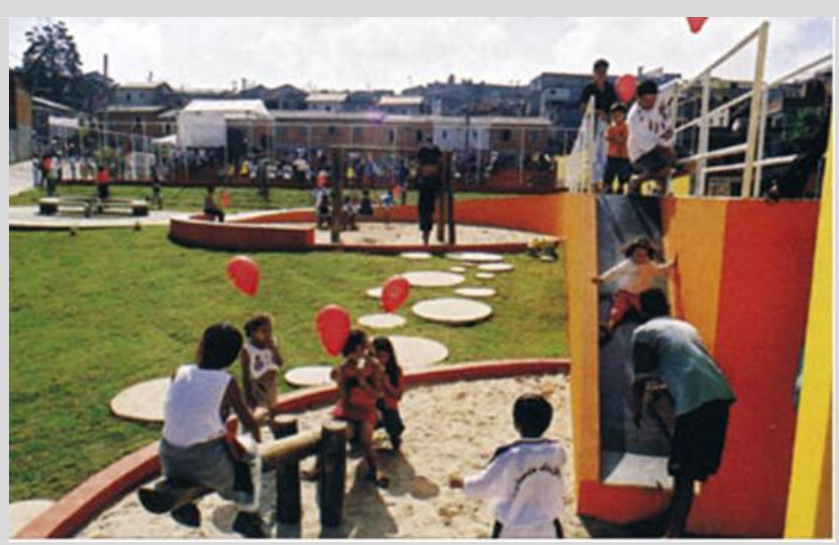

Praça em loteamento urbanizado pelo Lote Legal

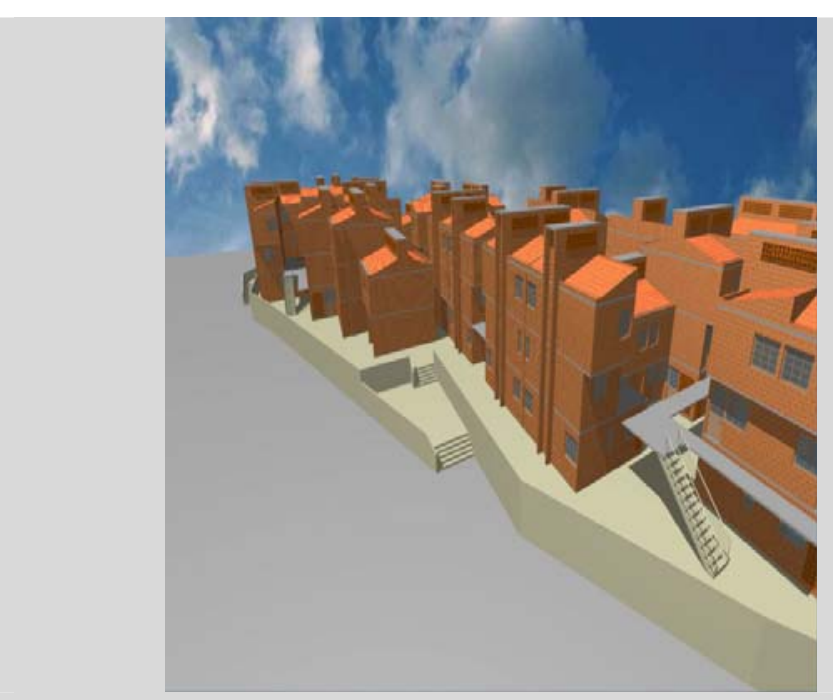

Fav. 2 de Maio - desenho da situação futura

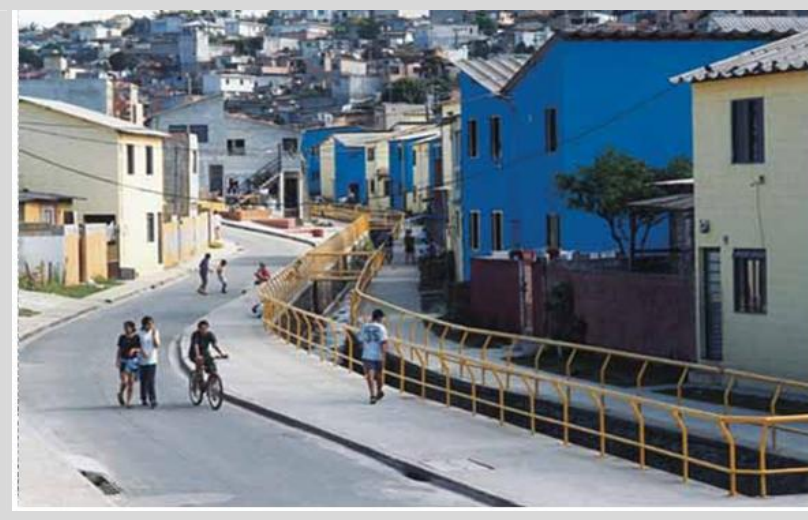

Favela urbanizada pelo Programa Mananciais

A COHAB, que havia desempenhado um papel secundário na política habitacional dos governos de 1993 a 2000, ficou com a responsabilidade da execução dos programas de provisão habitacional (exceto a continuidade do PROVER e PROCAV), além da requalificação e regularização de seus conjuntos habitacionais. Ao mesmo tempo, deu prosseguimento à quase totalidade dos programas e projetos em andamento, dentre eles, os empreendimentos do Programa Chamamento Empresarial, iniciados nas gestões Maluf e Pitta e do Programa de Mutirões iniciado na gestão Erundina, que ganhou agilidade e foi ampliado com a inclusão de novos convênios com associações de mutirantes e, portanto, de novos projetos. Além disso, pôs em execução novos programas de modernização administrativa, de redução da inadimplência da sua carteira de mutuários, de recuperação da sua saúde financeira, etc. 
Os programas de Mutirão com Autogestão, de Arrendamento Residencial, Morar no Centro e de Locação Social, ficaram sob responsabilidade da COHAB e, por se tratarem dos programas que envolveram a produção do maior número unidades (Mutirão e PAR) ou que apresentaram um maior grau de inovação, serão analisados especificamente nos itens 5.3, 5.4 e 5.5 do capítulo 5. Os demais programas implementados pela $\mathrm{COHAB}$ serão, resumidamente, caracterizados a seguir:

- "Bolsa Aluguel: "é um programa de apoio à Política Municipal de Habitação. Seu objetivo é viabilizar o acesso das famílias de baixo poder aquisitivo, beneficiárias do Fundo Municipal de Habitação, a uma moradia digna, através da concessão de subsídio para o complemento dos aluguéis e de garantia de locação, por período determinado". O programa disponibiliza "recursos mensalmente como complemento ao pagamento do aluguel (com tetos definidos por faixa de renda: quanto maior a renda, menor o auxílio) e, no início, um valor para a garantia do contrato (equivalente no máximo a três meses de aluguel). Assim, visa fomentar o parque privado de imóveis ao incluir essas famílias mais carentes no mercado formal de locação. 0 programa propõe-se a atender a população moradora de áreas sob intervenção das ações da Política Municipal de Habitação, estando ou não associadas a outros programas, inclusive conveniados. A demanda atendida será determinada pelos programas que terão o suporte do Bolsa Aluguel. É um programa de apoio às intervenções da Secretaria, não se caracterizando, portanto, como um programa "de balcão", aberto ao público em geral. Este programa procura estabelecer condições que permitam seus beneficiários atuarem efetivamente como cidadãos, com a intervenção do poder público sendo a menor possível. Ele propicia que o contrato de aluguel se estabeleça apenas disponibilizando recursos. Não há a participação efetiva do poder público na mediação do contrato de aluguel e na sua dinâmica. Assim, o Programa, ao mesmo tempo em que serve como uma ferramenta de apoio às atividades da Secretaria, atende às necessidades de habitação de parcela da população e fomenta o mercado privado de aluguéis, de forma a possibilitar um período de reestruturação para as famílias beneficiadas". (SEHAB APRESENTAÇÃO - BOLSA ALUGUEL - 12/03/04).

Além disso, o programa permite o atendimento emergencial de famílias que se encontrem em situação de desabrigo ou na iminência dela, 
oferecendo uma alternativa aos abrigos provisórios, que têm custo de construção e manutenção consideráveis, e exigem muito trabalho social para evitar ou solucionar situações complexas, que surgem pela sujeição, por muito tempo, às condições precárias do abrigo.

- Bairro Legal: é um programa que objetiva melhorias em assentamentos precários (favelas, loteamentos irregulares e conjuntos habitacionais degradados) podendo envolver as seguintes ações: trabalho social, obras de urbanização ou recuperação da infraestrutura quando existente e regularização jurídica. Na divisão de tarefas entre as várias áreas da SEHAB, coube à COHAB-SP a produção de habitações para famílias a serem removidas das favelas e loteamentos irregulares e as ações de requalificação e regularização de conjuntos habitacionais por ela construídos. As ações visando à requalificação dos conjuntos existentes ganharam um peso significativo, internamente à $\mathrm{COHAB}$, e passaram a ser tratadas como um programa específico, que recebeu o nome de "Viver Melhor na COHAB".

Um aspecto em que ocorreu um importante avanço resultante das ações da política habitacional implementada, no período 2001-2004, foi a melhoria do arcabouço legal e do desenho institucional, cujos benefícios foram sentidos em parte durante neste período, mas que deverão ser percebidos com maior intensidade nos períodos subseqüentes. CARDOSO e MOREIRA (2004, p. 79), MARQUES e SARAIVA (2005, p. 286) e FERREIRA (2006) apontam para esse aspecto. Os instrumentos, que constituem esse arcabouço legal e esse desenho institucional, foram concebidos na vigência do Estatuto da Cidade e formulados em consonância com essa lei. Compõem as melhorias no marco legal: a aprovação do Plano Diretor Estratégico e, com ele a criação das ZEIS; a criação do Conselho Municipal de Habitação, um novo decreto para HIS; uma série de leis de incentivos tributários; e um conjunto de novas leis sobre o uso e ocupação do solo, sobre edificações, e sobre a regularização de assentamentos precários. 


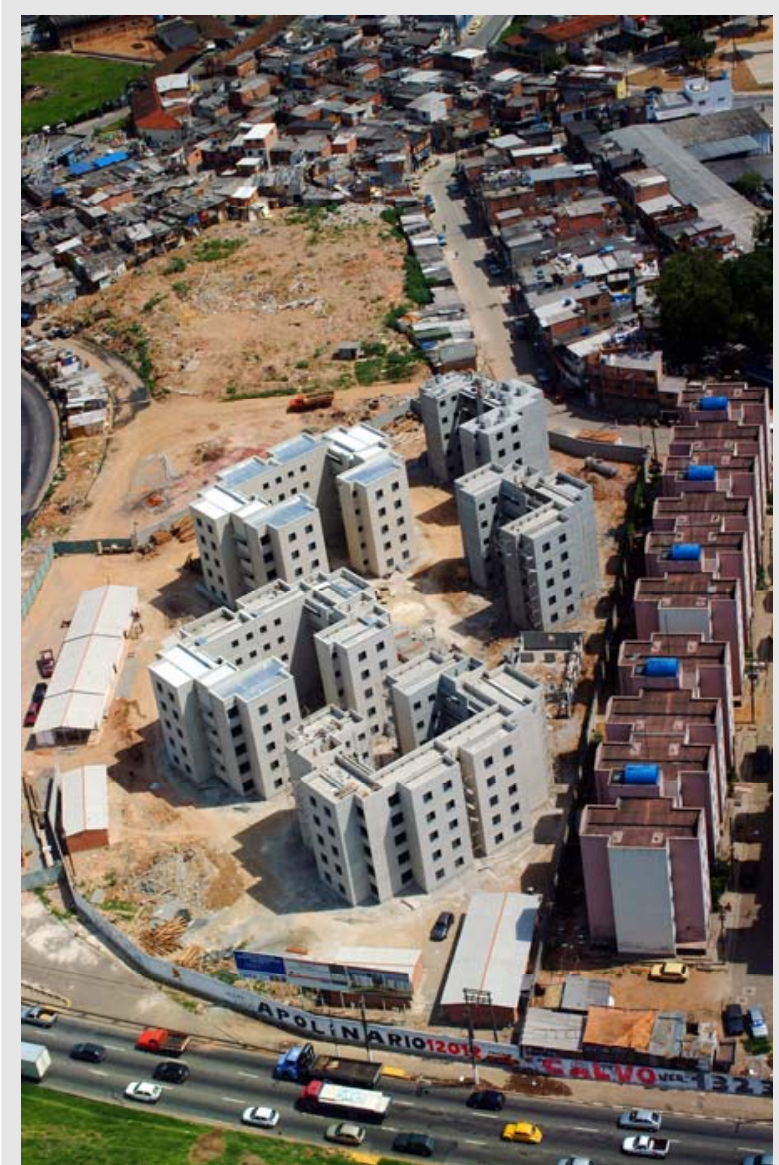

Lidiane II (foto: Robson Moreno, 2004)

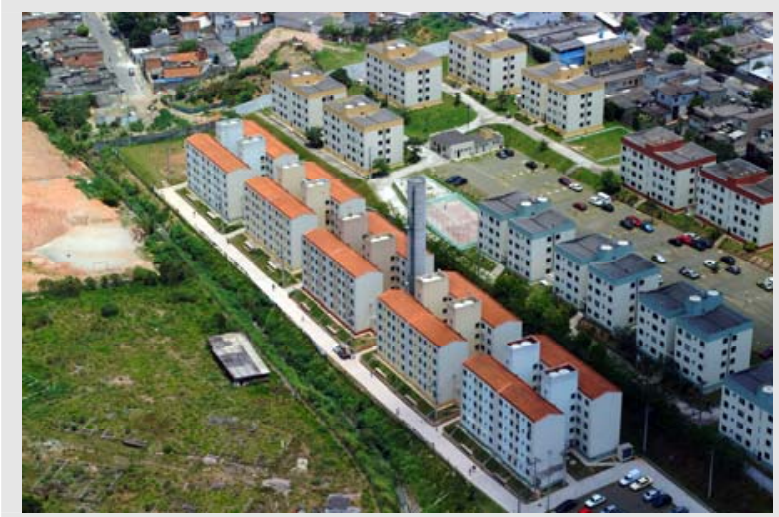

Jd. dos Cedros

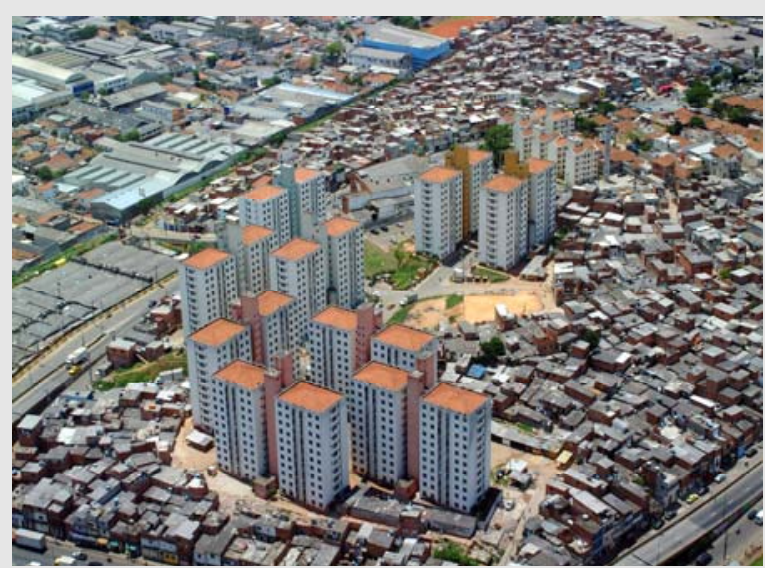

Heliópolis N

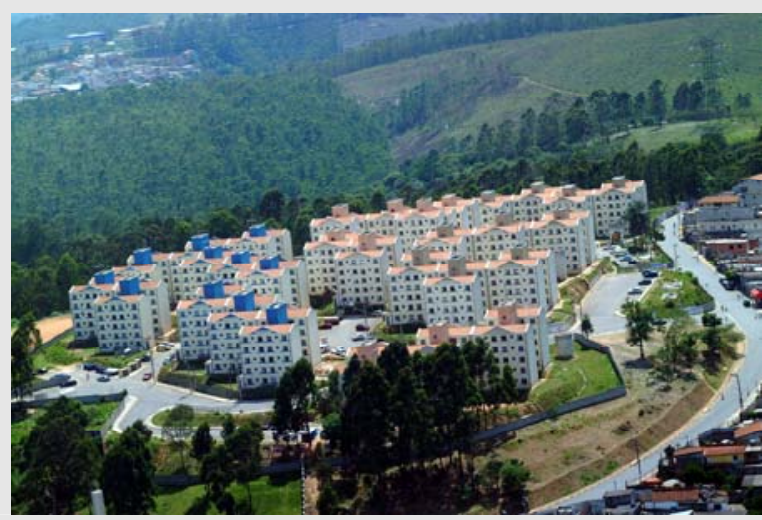

Irmãos Casemiro

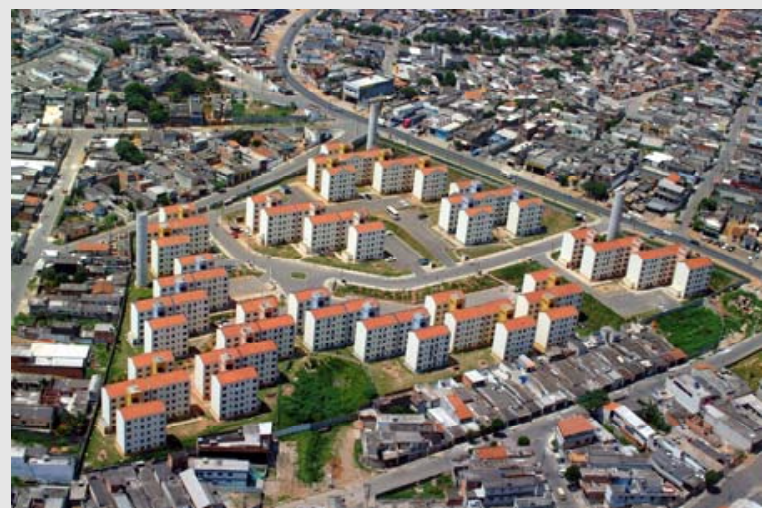

Jd. das Acácias

A construção de novos conjuntos pela COHAB-SP, no âmbito desse programa, contou com duas fontes de recursos: o FMH e os Convênios com a CDHU. Os Convênios com a CDHU formalizaram uma parceria entre Governo do Estado e a Prefeitura do Município de São Paulo, através das secretarias estadual e municipal de habitação e da CDHU e COHAB-SP, que tinha por objetivo produzir 5000 uh's, para 
atendimento a famílias residentes em favelas e em áreas de risco não situadas em favelas. Definiam como atribuições do Município a doação das terras e do Estado o financiamento dos projetos e obras, sendo que a contratação e o gerenciamento da execução de tais projetos e obras seria dividido entre CDHU e COHAB-SP.

- Parceria com a CEF: era um programa para atendimento a famílias de renda média (basicamente funcionários públicos), que teriam crédito consignado e financiamento com recursos do FGTS. Envolvia dois empreendimentos: Residencial São Paulo (Itaquera) e Bresser VI.

- Operações Urbanas: no âmbito da COHAB, consistia na provisão habitacional para famílias moradoras em favelas situadas nas áreas abrangidas pelas operações urbanas, através de empreendimentos a serem financiados com recursos obtidos pela venda de CEPAC' 


\subsection{Os recursos financeiros}

Conforme já apontado anteriormente, o grande comprometimento do orçamento do município levou a que se pensasse, desde as reuniões para elaboração do Programa de Governo, no Instituto Florestan Fernandes, que o financiamento dos programas habitacionais da PMSP exigiria um grande esforço na captação de recursos de outras fontes. Dessa forma, já nos primeiros seminários de planejamento estratégico, no início de 2001, boa parte dos programas propostos considerava a necessidade de parcerias: com a CEF, para viabilizar a construção de 5.000 uh's pelo PAR; e com o Governo do Estado de São Paulo, por intermédio da $\mathrm{CDHU}$, para viabilizar a construção de outras 5.000. Consideravam, também, a importância da continuidade dos financiamentos do BID (Banco Interamericano de Desenvolvimento), para o PROVER e Lote Legal, e do BIRD (Banco Mundial), para o Programa Guarapiranga e o seu sucessor, o Programa Mananciais.

Além disso, estava claro o imperativo de se buscar recursos em todas as outras linhas de financiamento disponíveis e de se buscar toda a redução de custos possível. Ou seja, desde o início, o cenário era de aperto, que só poderia ser contornado com novos recursos, provenientes de outras fontes além do Tesouro Municipal. E pode-se dizer que a prospecção por essas outras fontes e o esforço para a montagem de projetos para novos financiamentos foi uma das características mais importantes dessa gestão.

Portanto, além das fontes de financiamento mencionadas, foram obtidos recursos do BID para um novo programa, o Morar no Centro e do Governo Federal, através do Ministério das Cidades, dos Programas de Subsídio para Habitação de Interesse Social (PSH), Especial de Habitação Popular (PEHP), também do Ministério das Cidades, para o Plano de Ação em Favelas.

Alguns autores, que elaboraram trabalhos sobre a atuação da PMSP, na área de habitação, apontam que, durante a gestão de Marta Suplicy, teria havido uma redução dos recursos próprios da Prefeitura destinados à área, em relação ao que se verificou em administrações anteriores. Na Tabela 4.4, colocamos os dados apresentados por ROSSETTO (2003, p. 43), CARDOSO e MOREIRA (2004, p. 38) e MARQUES e SARAIVA (2005, p. 291), e também dados que obtivemos sobre 
valores efetivamente empenhados, pesquisando os Balanços Gerais da PMSP de 2000 a 2005.

Tabela 4.4 - Relações entre orçamentos da habitação (FABES e SEHAB) e da PMSP, e do Fundo e da habitação, conforme vários autores

\begin{tabular}{|c|c|c|c|c|c|c|c|}
\hline \multirow[b]{2}{*}{ Gestão } & \multirow[b]{2}{*}{ Anos } & \multicolumn{4}{|c|}{$\begin{array}{c}\text { \% da FABES ou SEHAB em relação ao } \\
\text { total da PMSP }\end{array}$} & \multicolumn{2}{|c|}{$\begin{array}{l}\text { \% do Fundo em } \\
\text { relação ao total da } \\
\text { FABES ou SEHAB }\end{array}$} \\
\hline & & $\begin{array}{l}\text { Rossella } \\
\text { Rossetto }\end{array}$ & $\begin{array}{l}\text { Cardoso } \\
\text { e Moreira }\end{array}$ & $\begin{array}{l}\text { Marques } \\
\text { e Saraiva }\end{array}$ & $\begin{array}{l}\text { Dados } \\
\text { obtidos } \\
\text { por esta } \\
\text { pesquisa }\end{array}$ & $\begin{array}{l}\text { Rossella } \\
\text { Rossetto }\end{array}$ & $\begin{array}{c}\text { Dados } \\
\text { obtidos } \\
\text { por esta } \\
\text { pesquisa }\end{array}$ \\
\hline \multirow{2}{*}{$\begin{array}{l}\text { Mário } \\
\text { Covas }\end{array}$} & 1984 & 0,3 & & & & 3 & \\
\hline & 1985 & 0,2 & & & & 2 & \\
\hline \multirow{3}{*}{$\begin{array}{l}\text { Jânio } \\
\text { Quadros }\end{array}$} & 1986 & 1 & & & & 20 & \\
\hline & 1987 & 2 & & & & 35 & \\
\hline & 1988 & 1 & & & & 23 & \\
\hline \multirow{4}{*}{$\begin{array}{l}\text { Luiza } \\
\text { Erundina }\end{array}$} & 1989 & 2 & 2 & \multirow{4}{*}{2,44} & & 41 & \\
\hline & 1990 & 3 & 3 & & & 53 & \\
\hline & 1991 & 4 & 4 & & & 56 & \\
\hline & 1992 & 4 & 4 & & & 77 & \\
\hline \multirow{4}{*}{$\begin{array}{l}\text { Paulo } \\
\text { Maluf }\end{array}$} & 1993 & 2 & 2 & \multirow{4}{*}{2,52} & & 70 & \\
\hline & 1994 & 2 & 2 & & & 23 & \\
\hline & 1995 & 2 & 2 & & & 8 & \\
\hline & 1996 & 4 & 5 & & & 9 & \\
\hline \multirow{4}{*}{$\begin{array}{l}\text { Celso } \\
\text { Pitta }\end{array}$} & 1997 & 3 & 4 & \multirow{4}{*}{3,46} & & 11 & \\
\hline & 1998 & 4 & 3 & & & 6 & \\
\hline & 1999 & 4 & 4 & & & 3 & \\
\hline & 2000 & 4 & 4 & & 5,35 & 12 & 10,55 \\
\hline \multirow{4}{*}{$\begin{array}{l}\text { Marta } \\
\text { Suplicy }\end{array}$} & 2001 & 3 & 3 & \multirow{4}{*}{2,33} & 2,80 & 10 & 5,23 \\
\hline & 2002 & 3 & 3 & & 2,64 & 11 & 11,04 \\
\hline & 2003 & & 2 & & 2,30 & & 10,98 \\
\hline & 2004 & & 2 & & 1,90 & & 24,22 \\
\hline J. Serra & 2005 & & & & 1,42 & & 19,76 \\
\hline
\end{tabular}

Fontes: ROSSETTO (2003, p. 43), CARDOSO e MOREIRA (2004, p. 38), MARQUES e SARAIVA (2005, p. 291) e

PMSP, "Balanços Gerais", 2001-2006

Apesar das discrepâncias ${ }^{40}$, os dados apresentados apontam que, na gestão de Marta Suplicy, a SEHAB (inclusive o FMH) teria recebido do Orçamento

40 Quando percebidas essas discrepâncias, não havia mais tempo para que esta pesquisa obtivesse dados complementares, que permitissem opinar sobre quais seriam os mais corretos dentre os apresentados. 
Municipal, uma porcentagem menor do que nas gestões que a antecederam. No entanto, é conveniente lembrar que os dados tal como mostrados aqui não refletem perfeitamente o grau de prioridade dado à habitação em cada gestão. Por exemplo, na gestão Pitta, muitos recursos foram destinados ao aumento de capital da COHAB ( $R$ \$ 84,2 milhões em 2000, contra $R \$ 74,9$ em 2001), num momento em que sua folha de pagamento consumia altos valores, por uma opção "política" e não técnica. A respeito da relação entre investimento e produção, MARQUES e SARAIVA (2005, p. 293) afirmam:

"Na primeira gestão do $P T$, verificou-se uma produção física muito elevada em moradias novas e urbanizações de favela, apesar dos volumes de investimento e gasto mais reduzidos, sugerindo eficácia elevada dos gastos. As gestões do PDS/PPB, ao contrário, apresentaram investimentos e gastos elevados, mas produções relativamente reduzidas, exceto pelo número significativo de loteamentos regularizados na gestão de Celso Pitta".

Comentando sobre as prioridades do Governo de Marta Suplicy, CARDOSO e MOREIRA (2004, p. 37) dizem:

Com uma forte pressão financeira, decorrente do alto endividamento público e do conseqüente compromisso assumido junto ao governo federal [negociação do governo Pitta com o governo de Fernando Henrique Cardoso], a alternativa adotada para atender a diretriz de diferenciação foi a de concentrar a atuação governamental em um pequeno grupo de programas em setores escolhidos, concentrando os recursos disponíveis e buscando construir intervenções que pudessem exprimir de forma clara a "marca" da gestão. Essa estratégia se materializou, basicamente, através de três políticas: a educacional, com os CEU's, a de saúde, com o Programa Saúde de Família e a inserção no SUS, e a política de inclusão social".

A essas três políticas entendemos que deveria ser acrescentada uma quarta: a de transportes.

No já mencionado quadro de constrangimento financeiro geral, agravado pelo fato de não constar entre os setores prioritários para o governo, coube ao setor da habitação trabalhar no sentido de obter recursos de outras fontes que não o orçamento da PMSP. A Tabela 4.5 indica os valores orçamentários e nãoorçamentários empregados no setor da habitação, entre 2001 e 2004. 
Tabela 4.5 - Recursos orçamentários e não-orçamentários para o setor de habitação da PMSP (valores em R\$ 1000, atualizados para 2004)

\begin{tabular}{|c|c|c|c|c|c|}
\hline Recursos Orçamentários da PMSP & 2001 & 2002 & 2003 & 2004 & $\begin{array}{c}\text { Total Gestão } \\
\text { 2001-2004 }\end{array}$ \\
\hline Recursos Próprios & 332.268 & 273.559 & 180.916 & 226.592 & 1.013 .335 \\
\hline $\mathrm{BID}$ & 28.234 & 55.707 & 26.266 & 6.723 & 116.930 \\
\hline BID Centro & - & - & - & 30.561 & 30.561 \\
\hline Total do Orçamento Municipal & 360.502 & 329.266 & 207.182 & 263.876 & 1.160 .826 \\
\hline PAR COHAB - Contrução & 3.751 & 10.215 & 16.451 & 26.403 & 56.820 \\
\hline PAR COHAB - Reforma & & 2.240 & 4.453 & 7.581 & 14.274 \\
\hline PAR Iniciativa Privada - Contrução & & & 56.683 & & 56.683 \\
\hline PAR Iniciativa Privada - Reforma & & & 9.943 & 5.868 & 15.811 \\
\hline Emendas Federais & & & & 1.284 & 1.284 \\
\hline Convênios com o CDHU & & 12.211 & 10.537 & 9.321 & 32.069 \\
\hline Cities Alliance & & & 973 & & 973 \\
\hline $\mathrm{PSH}$ & & & & 18.337 & 18.337 \\
\hline PEHP & & & & 18.337 & 18.337 \\
\hline Convênio com a Embaixada Japonesa & & & & 1.019 & 1.019 \\
\hline Operações Urbanas (Faria Lima e Águas Espraiadas) & & & 4.863 & & 4.863 \\
\hline Total de recursos não-orçamentários & 3.751 & 24.666 & 103.903 & 88.150 & 220.470 \\
\hline Total de recursos & 364.253 & 353.932 & 311.085 & 352.026 & 1.381 .296 \\
\hline Relação Não-orçamentários/ Orçamentários & $1,03 \%$ & $6,97 \%$ & $33,40 \%$ & $25,04 \%$ & $15,96 \%$ \\
\hline
\end{tabular}

Fonte: PMSP/SEHAB, "Balanço Qualitativo de Gestão 2001-2004", 2001, p. 102

Obs.: Índice utilizado: Índice de Preços ao Consumidor Amplo - IPCA, calculado pelo IBGE. Os recursos orçamentários não incluem despesas de pessoal.

A Tabela 4.5 indica a importância que os recursos não-orçamentários tiveram para a política habitacional do período 2001-2004. Esses recursos variaram de $1,03 \%$ a 33,4\% dos orçamentários, ficando ao longo dos quatro anos em torno de 16\%. Dentre os não-orçamentários, tiveram maior peso aqueles provenientes do PAR. Sendo que a expectativa que havia sobre a entrada de recursos por intermédio do Convênio com a CDHU, não se confirmou.

A tabela 4.6 apresenta valores (históricos) realizados de dotações do Orçamento da PMSP. Dentre outras coisas, é interessante observar os valores decrescentes do aumento de capital da COHAB e a participação do FMH no total dos recursos para a SEHAB, que, entre 2001 e 2004, variou de 5,23\% para 24,22\%. O que indica que uma parcela muito significativa dos recursos destinados a habitação não passa por esse Fundo e, portanto, geralmente, são aplicadas sem que tenham passar por aprovação do Conselho Municipal de Habitação. 
Tabela 4.6 - Recursos orçamentários para o setor de habitação da PMSP (valores históricos)

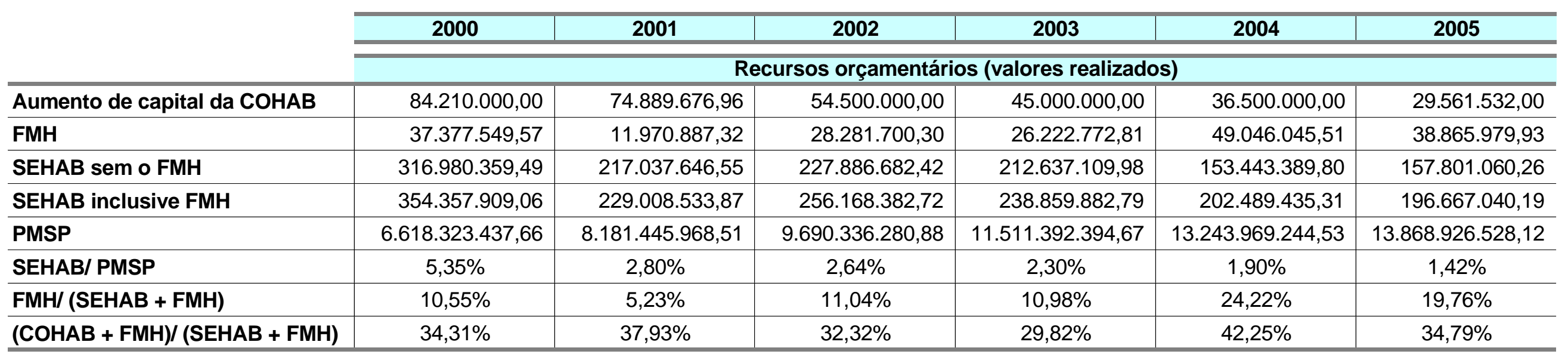

Fontes: PMSP, "Balanços Gerais", 2001-2006 


\subsection{O Fundo Municipal de Habitação e seu Conselho}

O Fundo Municipal de Habitação (FMH) e o Conselho Municipal de Habitação (CMH) serão discutidos neste item, pela importância que têm no desenho institucional da política municipal de habitação, da qual, juntamente com a SEHAB e a COHAB-SP, são os principais instrumentos de gestão. E como já foi dito, por ser também o FMH a maior fonte de recursos para investimentos da COHAB.

A criação de fundos específicos para habitação é uma demanda da grande maioria dos movimentos por moradia e dos técnicos que atuam na área. Uma grande campanha nacional, encabeçada por organizações e movimentos sociais ${ }^{41}$. encaminhou ao Congresso Nacional, em novembro de 1991, um projeto de lei de iniciativa popular, que propunha a criação de um Fundo Nacional de Moradia Popular. Esse projeto, depois de tramitar no Congresso por 13 anos, resultou na criação do Fundo Nacional de Habitação de Interesse Social (FNHIS), em maio de 2005.

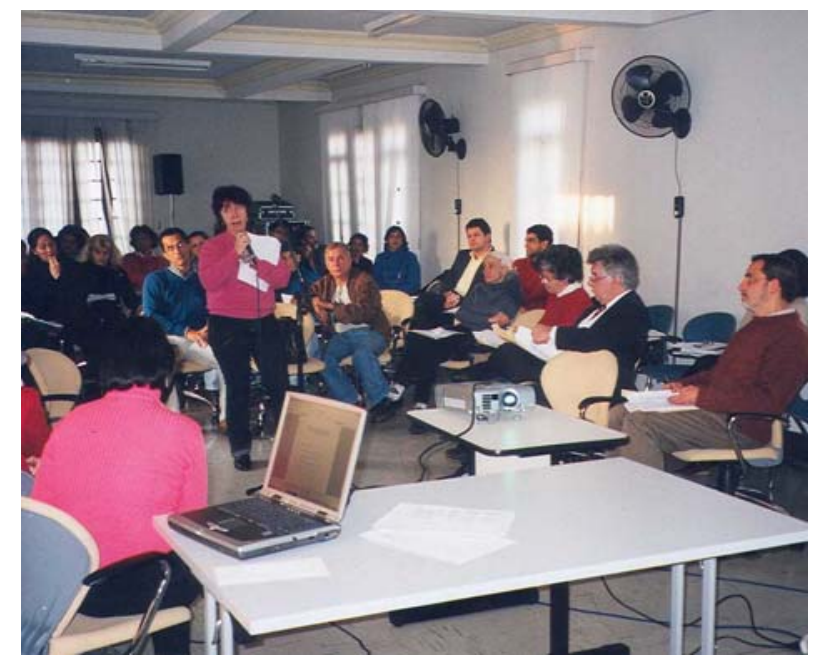

Foto... - Reunião do Conselho Municipal de Habitação (Arquivo COHAB-SP)
Os fundos públicos são contas específicas, que podem receber recursos de várias fontes, cuja aplicação deve atender a determinados objetivos (por exemplo, financiar habitação) e em cuja operação têm que ser observados alguns dispositivos legais diferentes daqueles que são observados na operação do restante do orçamento, por exemplo, o dispositivo que trata da "anualidade". O Artigo 73 , da Lei $4320 / 64{ }^{42}$, afirma que:

"o saldo positivo do fundo especial apurado em balanço será transferido para o exercício seguinte, a crédito do mesmo". Nisso, os fundos diferem das outras dotações que, caso não tenham sido utilizadas até o final do exercício, retornam ao "caixa único" do órgão (governo federal, estadual ou municipal). 
As propostas de criação desses fundos contam com tantos apoios dos movimentos e dos técnicos que atuam na área por vantagens que apresentam para as políticas setoriais. Vantagens que, para Rossella ROSSETTO (2003, p. 13, 14 e 19), estariam na possibilidade (que nem sempre se efetiva) de: $\mathbf{1}^{\circ}$.) democratização das decisões sobre a alocação dos recursos, pois, geralmente, são geridos por conselhos, que, potencialmente, são espaços de participação da sociedade civil; $\mathbf{2}^{\circ}$.) maior garantia de que os recursos chegarão ao seu destino e não se "perderão" na execução orçamentária; $\mathbf{3}^{\mathbf{0}}$.) reunir recursos de várias fontes: outras esferas de governo, doações da iniciativa privada, captação no mercado imobiliário (por exemplo, operações interligadas e outorga onerosa) e, no caso da habitação, receber as prestações pagas pelos mutuários; e $\mathbf{4}^{\circ}$.) não terem que obedecer ao já mencionado dispositivo da "anualidade".

Além disso, existem aqueles que vêm uma outra vantagem na criação de fundos, que consistiria na possibilidade de que receitas orçamentárias fossem a eles vinculadas. Possibilidade que entendem que seria dada pela Lei Federal 4320/64. No entanto, essa questão é um tanto controversa, pois existem juristas ${ }^{43}$ que apontam que a Constituição Federal, no artigo 167, inciso IV, vedaria vinculações de receitas de impostos, exceto em alguns casos previstos em sua redação original (por exemplo, 25\% para educação) ou acrescentados por emendas constitucionais.(por exemplo, 15\% para saúde até 2004, fixado pela Emenda Constitucional n ${ }^{\circ}$. 29). Porém, permitiria vinculações de receitas provenientes de taxas, contribuições, empréstimos e de outros fundos.

A Prefeitura de São Paulo, desde 27/4/1979, dispunha de um fundo para financiar habitação social, o Fundo de Atendimento à População Moradora em Habitação Subnormal (FUNAPS), criado pela Lei 8.906/79. Em 22/7/1994, pela Lei 11.632/94, foi instituído o Fundo Municipal de Habitação (FMH) e extinto o FUNAPS.

41 Fórum Nacional de Reforma Urbana, CONAM (Confederação Nacional das Associações de Moradores), CMP (Central de Movimentos Populares), UNMP (União Nacional por Moradia Popular) e MNLM (Movimento Nacional de Luta por Moradia).

42 Lei que fixa normas para a elaboração e controle dos orçamentos e balanços da União, estados, municípios e Distrito Federal.

43 Aldemario Castro (www.aldemario.adv.br/stf2003.htm), Amarildo Costa (jus2.uol.com.br/doutrina/ texto.asp?id=3187), Kiyoshi Harada (jus2.uol.com.br/doutrina/texto.asp?id=1414), Vander Gontijo (www2.camara.gov.br/orcamentobrasil/cidadao/entenda/cursopo/index.html). 
Este trabalho não pôde se estender e realizar uma pesquisa em maior profundidade sobre as motivações que levaram à criação do $\mathrm{FMH}$ e à extinção do FUNAPS, na gestão Maluf. Mas cabe lembrar de alguns problemas que este último apresentava e que, provavelmente, buscou-se solucionar com a criação do primeiro. O maior desses problemas era a questão da personalidade jurídica. A interpretação que predominava, no mínimo, a partir de meados da gestão Erundina, era a de que o FUNAPS, enquanto fundo, não poderia possuir patrimônio (imóveis, etc.), mover ações de reintegração de posse e realizar contratações de serviços e pessoal, como havia feito ${ }^{44}$.

Outra questão importante que foi utilizada para justificar o FMH era a duplicidade de agentes que realizavam coisas semelhantes (COHAB e HABI) e a segmentação do atendimento habitacional pelo Município. No livro em que estuda o FMH, Rossella ROSSETTO (2003, p. 57) diz que Lair Krahenbul, Secretário da Habitação do Município, quando da criação do Fundo, na audiência pública sobre o projeto de lei que propunha essa criação, afirmou que era necessário evitar a duplicidade e segmentação e que todos os recursos deveriam ser reunidos num único fundo. No entanto, mesmo após a criação do FMH e com o mesmo secretário, não ocorreu essa reunião de recursos e COHAB e HABI continuaram a executar programas semelhantes.

No livro mencionado, Rossella ROSSETTO (p. 56) compara as características desse fundo, quando de sua criação, e as do FUNAPS. Por essa comparação, algumas das principais diferenças estariam em:

- Possibilidade do FMH financiar unidades para uso misto e equipamentos comunitários, que para o FUNAPS não existia.

- Faixas de renda da população a ser atendida:

- pelo FUNAPS, seria de até 4 salários mínimos (SM), acrescidos de 0,5 SM para cada pessoa, no caso de famílias com mais de 4 membros; e

\footnotetext{
44 Segundo a Profa. Ermínia MARICATO (1997, p. 78), Secretária da Habitação e Desenvolvimento Urbano, na gestão Erundina, foi encaminhado à Câmara Municipal, durante essa gestão, um projeto de lei que propunha a criação de uma fundação, visando solucionar a questão da falta de personalidade jurídica do FUNAPS, mas que não chegou a ser votado.
} 
- pelo $\mathrm{FMH}$, até $10 \mathrm{SM}$, com prioridade para as famílias com até 5 $\mathrm{SM}$.

- Composição do Conselho:

- para o FUNAPS, eram 7 membros, sendo 2 representantes do executivo (o Secretário da Habitação e o Superintendente de Habitação Popular), 3 de livre escolha do prefeito, 2 representantes da população moradora em habitação subnormal indicados pelos representados; e

- para o FMH (da sua criação até a criação do Conselho Municipal de Habitação, em 2/9/2002), eram 10 membros, desses, 5 eram representantes do executivo, 2 de organizações comunitárias ligadas à moradia, 1 representante da indústria da construção, 1 de entidade religiosa, 1 da universidade; sendo os 5 primeiros definidos por lei e os 5 últimos por sorteio entre os inscritos.

- Desenho institucional:

- o FUNAPS era ligado à administração direta e teve, a partir de 1986, a HABI como promotora e operadora;

- o FMH ficou vinculado à COHAB-SP (administração indireta), que é sua operadora; tem a SEHAB como promotora e a HABI, representada por seu superintendente, como Secretária Executiva de seu conselho.

Há uma certa polêmica quanto aos prós e contras do desenho institucional do $\mathrm{FMH}^{45}$. E quase toda essa polêmica gira em torno das vantagens e desvantagens do Fundo ter a $C O H A B$ como seu agente operador e não um órgão da administração direta, como a HABI era do FUNAPS.

Entre os prós, lista-se que:

a. A COHAB conferiu ao FMH uma personalidade jurídica, que faltava ao FUNAPS. Dessa forma, a COHAB representa o FMH e pode adquirir imóveis, firmar contratos para a execução de serviços e obras

45 Rossella ROSSETTO, em livro publicado em 2003, onde apresenta uma importante discussão sobre os fundos em geral e, em especial, sobre o $\mathrm{FMH}$, coloca as principais questões relativas ao desenho institucional desse fundo. 
e de financiamento com mutuários. Como já foi dito, esses fundos não poderiam possuir propriedades e assinar contratos, necessitando que essas propriedades e contratos estivessem em nome do órgão ao qual fosse vinculado (por exemplo: Prefeitura ou COHAB). Para alguns dos profissionais que estudam essa questão, a COHAB teria uma maior agilidade para firmar contratos com mutuários do que se poderia esperar de um órgão da administração direta e isso se constituiria em uma vantagem para os beneficiários do atendimento e para o sistema como um todo, porque abreviaria o retorno dos financiamentos. Outros profissionais apontam para uma maior celeridade da COHAB para mover ações jurídicas de reintegração na posse e efetuar desapropriações. Mas se há dúvidas sobre a diferença de celeridade entre essa empresa e um órgão da administração direta, para firmar contratos com mutuários, parece que não deveria haver dúvidas sobre a possibilidade da COHAB ser mais ágil em reintegrações de posse e em desapropriações.

b. A COHAB, por ser empresa, teria maior agilidade do que um órgão da administração direta para contratar serviços, obras e pessoal. Em relação a isso, contrapõe-se que a COHAB, como empresa de capital misto, também é obrigada a realizar licitações, para contratar serviços e obras, e concursos públicos, para contratar pessoal, seguindo a mesma legislação que tem que ser obedecida pela administração direta. Nesse aspecto, a maior diferença estaria na possibilidade da COHAB efetuar demissões com maior agilidade do que a administração direta, por contratar pela CLT, e estabelecer salários e um regime de promoções mais condizente com o mercado, por não estar submetida ao Regime Jurídico Único, como a administração direta.

Dentre os contras, relaciona-se que:

a. A COHAB recebe uma remuneração para prestar serviços ao FMH e também contrata uma gerenciadora para o Programa de Mutirões e isso encareceria os empreendimentos. 
Essa remuneração pelos serviços da COHAB, até a gestão Marta ${ }^{46}$, era de $4,5 \%$ dos valores desembolsados para pagamento de serviços, obras, etc.; de $\mathrm{R} \$ 4,65$ por contrato (com mutuários, etc.), na fase de administração dos créditos; e de 0,16\% incidente sobre o saldo devedor de cada contrato. Tal remuneração da COHAB e as despesas com a contratação de uma gerenciadora para o programa de mutirões, efetivamente, têm que ser agregadas ao custo dos empreendimentos. No entanto, não é possível, imediatamente, inferir que, pelo fato de ser a COHAB o órgão operador do $\mathrm{FMH}$ e, além disso, ser necessária também a contratação de uma gerenciadora, a produção dos empreendimentos teria um custo maior para o Município, do que teria por intermédio da administração direta. Cabe lembrar que a administração direta também tem recorrido às gerenciadoras (HABI, RESOLO, Programa Mananciais). A análise requerida para uma comparação como essa é um bocado complexa, pois, ao que se saiba, não existem dados empíricos sobre uma produção qualitativa e quantitativamente semelhante e em contextos também semelhantes, pela COHAB e por um órgão da administração direta como HABI, por exemplo. Dessa forma, seria necessário montar um modelo teórico, em que teriam que ser estimados, computados e alinhados lado a lado, tanto para o órgão da administração direta, quanto para a empresa da administração indireta, todos os custos para o Município do planejamento, produção, ocupação e pós-ocupação e administração de contratos (com mutuários, permissionários ou locatários) de empreendimentos e programas, considerando os homens/hora e seu custo, do órgão, da empresa e das gerenciadoras que trabalhem para ambos.

Algumas comparações desse tipo têm incorrido em esquecimentos e simplificações. Esquecimento de que a remuneração dos funcionários da administração direta, apesar de sair de uma rubrica diferente da do $\mathrm{FMH}$, ao contrário da remuneração da COHAB, também onera as

${ }^{46} \mathrm{Na}$ gestão de Gilberto Kassab, que sucedeu a José Serra, foi proposta uma elevação da remuneração da COHAB. Mas não obtivemos informação sobre se foi aprovada e quais os valores propostos. 
dotações para habitação do Orçamento Programa do Município. Raciocínios desse tipo tendem a levar a questionamentos sobre o fato da remuneração média dos funcionários da COHAB ser superior à remuneração média dos funcionários da administração direta. Ao que parece esse fato é real, sem bem que não conheçamos estudos que o comprove. Mas ao se ampliar os parâmetros analisados, seria fundamental que se considerasse o conjunto dos custos, inclusive os previdenciários e também a produtividade, em ambos os casos ${ }^{47}$.

Ainda sobre essa questão da incidência sobre os custos da remuneração da $\mathrm{COHAB}$, cabe lembrar que ela tem sido remunerada em função dos desembolsos para as empresas por ela contratadas para prestar serviços para empreendimentos financiados com recursos do FMH (projetistas, construtoras, etc.). Todos os desembolsos que são realizados até o início da obra (estudo de viabilidade, seleção e aquisição de terrenos e elaboração de projetos) são de baixo valor e demoram muito para acontecer. Por exemplo, até a conclusão de cada uma das etapas mais importantes de um projeto (ante-projeto/estudo preliminar, projeto básico, projeto executivo) não há nenhum desembolso para as contratadas e, portanto, também não há para a COHAB. Mas muito trabalho é realizado (elaboração de estudo preliminar e de termo de referência, licitação para a contratação de projetista, execução, análises e revisões do projeto, etc.) e muito tempo se passa até que o produto seja aceito pelos técnicos da Companhia e efetuado o desembolso para a contratada (no caso, a projetista), que dará direito à $\mathrm{COHAB}$ de ser remunerada pelo $\mathrm{FMH}$.

\footnotetext{
${ }^{47}$ A diferença de remuneração entre os funcionários da COHAB e da SEHAB é uma questão que tem implicações sobre a motivação de parcela desses funcionários, evidentemente que mais entre os últimos, e é objeto de questionamentos, brincadeiras, etc. Seria importante que se buscasse um melhor equacionamento para essa questão, pois contribui para a existência de algumas arestas no relacionamento entre a Companhia e a Secretaria. Mas não se pode desconhecer a dificuldade (ou mesmo impossibilidade) de se equiparar os salários da administração indireta e da direta, seja pelo aumento dos salários da administração direta, seja pela redução dos salários da administração indireta.
} 


\section{b. Maior dificuldade para a passagem de recursos para COHAB e também maior dificuldade de controle sobre essa Companhia:}

Ou seja, também são apontados como aspectos negativos do FMH ser operado pela $\mathrm{COHAB}$ o fato de que haveria:

- Dificuldade maior para que os recursos chegassem do Tesouro ao $\mathrm{FMH}$, por ele estar na $\mathrm{COHAB}$, do que haveria se estivesse em algum órgão da administração direta, pois teriam que, antes, passar pela SEHAB;

- Dificuldade maior para um controle externo (por vereadores e cidadãos) das aplicações dos recursos do FMH pela $\mathrm{COHAB}$, pois essas aplicações (pagamentos pela aquisição de terras, execução de estudos, projetos e obras, etc.) não são registradas no Sistema de Execução Orçamentária (SEO), que controla todas as outras dotações e despesas da PMSP. Esse sistema, que é acessível aos vereadores e, segundo Rossella ROSSETTO (2003, p. 63), também a todos os cidadãos pela Internet, só indicaria o repasse de grandes montantes da SEHAB para a conta FMH da COHAB e não os pagamentos que ela efetuaria para cada serviço que venha a contratar. Se bem que se ressalve que a COHAB presta contas à SEHAB e ao Conselho Municipal de Habitação. Além do que, cabe lembrar, está sujeita a auditorias do Tribunal de Contas e de empresa independente

- Possibilidade de que a COHAB venha a utilizar os recursos do FMH de acordo com suas necessidades e sem observar a destinação dos recursos dada pelo $\mathrm{CMH}$.

- Possibilidade de que a COHAB, por estar acostumada a trabalhar com os recursos do SFH e com as regras que buscam garantir o retorno dos financiamentos a esse sistema, tendesse a privilegiar investimentos com retorno mais garantido, voltados a faixas de maior renda, dentre as de baixa renda (de 4 a 10 salários mínimos, por exemplo), e 
a ser refratária aos investimentos destinados aos estratos de menor renda (de 0 a 3 salários mínimos, por exemplo).

Em relação a essas últimas questões, cabe colocar que não é significativa a dificuldade da passagem dos recursos para 0 $\mathrm{FMH} / \mathrm{COHAB}$ e que existem, inclusive, aqueles que apontam que o Fundo na $\mathrm{COHAB}$, permitiria uma maior autonomia em relação à Secretaria de Finanças (SF), pois os recursos, depois de repassados ao $\mathrm{FMH}$, não teriam sua liberação condicionada às cotas de liquidação estabelecidas por essa secretaria.

Quanto ao controle externo e à possibilidade da COHAB realizar investimentos de acordo com suas próprias prioridades e não com aquelas fixadas pelo $\mathrm{CMH}$, cabe lembrar que a COHAB tem uma conta específica em que movimenta os recursos do $\mathrm{FMH}$ de forma totalmente separada dos seus recursos próprios, e que tem que seguir as determinações do $\mathrm{CMH}$ e lhe prestar contas. Lembrar ainda que desobediência pela COHAB das normas que tratam dessa matéria configuraria um crime contra a administração pública, pelo qual seriam responsabilizados seus diretores e funcionários envolvidos.

Agora, é real o que se menciona quanto a uma maior dificuldade para que vereadores e cidadãos, que não os integrantes do $\mathrm{CMH}$, acompanhem as aplicações pela COHAB dos recursos do FMH. Mas esse problema poderia ser contornado, se se incluísse a conta $\mathrm{COHAB/FMH} \mathrm{no} \mathrm{sistema} \mathrm{da} \mathrm{Prefeitura} \mathrm{que} \mathrm{abrange} \mathrm{as} \mathrm{demais}$ dotações.

Em relação, a uma dificuldade da $C O H A B$ ajustar-se às prioridades do $\mathrm{CMH}$ e tender a utilizar recursos do Fundo de forma diversa da prevista por esse conselho, cabe também o que já foi falado acima: a Companhia tem que obedecer ao que determina o Conselho sobre prioridades de aplicação e condições de financiamento, não possuindo a autonomia aventada.

Em 1999, foi apresentado pelo Vereador Adriano Diogo projeto de lei de criação do Conselho Municipal de Habitação (CMH). Apenas em 2002, depois de aprovado pela Câmara Municipal e sancionado pela Prefeita Marta Suplicy, tal 
projeto foi convertido na Lei $n^{\circ}$. 13.425/02, que instituiu o Conselho Municipal de Habitação de São Paulo, que substituiria o Conselho do Fundo Municipal de Habitação. Em relação a esse último, o CMH se diferencia por:

- Ser paritário, composto de 1/3 de representantes do Poder Público, 1/3 de representantes de entidades comunitárias e populares ligadas à habitação, e 1/3 de representantes de entidades da sociedade civil, com atuação também relacionada à habitação, que serão indicadas adiante (sindicatos de trabalhadores e patronais, universidades, etc.).

- Ter o número de conselheiros ampliado de 10 para 48.

- Ter atribuições mais amplas, não se restringindo à gestão do Fundo Municipal de Habitação, mas abrangendo toda a política habitacional e todos os recursos consignados à SEHAB.

Os membros do Conselho Municipal de Habitação têm mandato de dois anos. Os primeiros conselheiros tomaram posse em $1^{\circ}$ de junho de 2003 . O Conselho tem a seguinte composição, cabendo a cada titular um suplente:

- 16 representantes do Poder Público, sendo:

- 5 representantes da SEHAB, 2 da COHAB-SP e 1 de cada uma das seguintes secretarias e órgãos municipais: Planejamento, Infra-Estrutura Urbana, Finanças, Desenvolvimento e Trabalho, EMURB, Procentro;

- 1 da Secretaria de Habitação do Estado;

- 1 da CDHU;

- 1 da Caixa Econômica Federal.

- 16 representantes de entidades comunitárias e de organizações populares ligadas à habitação, eleitos de forma direta.

- 16 representantes da sociedade, eleitos por seus respectivos segmentos:

- 2 professores ou pesquisadores de universidades ligadas à área habitacional;

- 2 de entidades de profissionais da área habitacional (sindicatos, associações);

- 1 de entidades sindicais dos trabalhadores da construção civil; 
- 3 das associações ou sindicatos patronais da indústria da construção civil;

- 2 de entidades que prestam assessoria técnica na área habitacional (HIS);

- 2 de centrais sindicais;

- 2 de ONGs que atuam na área habitacional;

- 1 de conselho de categoria profissional da área habitacional;

- 1 de conselho de categoria profissional do direito.

Dos dispositivos da Lei que criou o $\mathrm{CMH}$, os seguintes configuram seu caráter e principais competências:

"Art. $1^{\circ}$ - Fica criado, no âmbito da Secretaria Municipal de Habitação e Desenvolvimento Urbano, o Conselho Municipal de Habitação de São Paulo, que atuará em conformidade com os princípios consagrados no artigo 168 da Lei Orgânica do Município de São Paulo e artigo $2^{\circ}$ do Estatuto da Cidade, lei federal 10.257 de 10 de julho de 2001.

Art. $2^{\circ}$ - O Conselho Municipal de Habitação tem caráter deliberativo, fiscalizador e consultivo e como objetivos básicos o estabelecimento, acompanhamento, controle e avaliação da política municipal de habitação.

Art. $3^{\circ}$ - Compete ao Conselho Municipal de Habitação:

I. participar da elaboração e fiscalizar a implementação dos planos e programas da política habitacional de interesse social, deliberando sobre suas diretrizes, estratégias e prioridades;

II. acompanhar e avaliar a gestão econômica, social e financeira dos recursos e o desempenho dos programas e projetos aprovados;

III. participar da elaboração do plano de aplicação dos recursos financeiros oriundos dos Governos Federal, Estadual, Municipal ou repassados por meio de convênios internacionais e consignados na SEHAB;

IV. fiscalizar a movimentação dos recursos financeiros consignados para os programas habitacionais;

V. constituir grupos técnicos, comissões especiais, temporárias ou permanentes, quando julgar necessário para o desempenho de suas funções;

VI. constituir comissão especial para organização de Conselhos Regionais de Habitação; 
VII. estimular a participação e o controle popular sobre a implementação das políticas públicas habitacionais e de desenvolvimento urbano;

VIII. possibilitar ampla informação à população e às instituições públicas e privadas sobre temas e questões atinentes à política habitacional;

IX. convocar a Conferência Municipal de Habitação;

$X$. estabelecer relações com os órgãos, conselhos e fóruns municipais afectos à elaboração do Orçamento Municipal à definição da política urbana;

XI. elaborar, aprovar e emendar o seu Regimento Interno;

XII. articular-se com as demais instâncias de participação popular do Município;

XIII. definir os critérios de atendimento de acordo com base nas diferentes realidades e problemas que envolvam a questão habitacional no Município.

Art. $4^{\circ}$ - O Conselho Municipal de Habitação supervisionará o Fundo Municipal de Habitação, competindo-Ihe especificamente:

XIV. estabelecer as diretrizes e programas de alocação dos recursos do Fundo Municipal de Habitação, de acordo com os critérios definidos na Lei 11632/94, em consonância com a política municipal de habitação;

XV. encaminhar e aprovar, anualmente, a proposta de orçamento do FMH e de seu plano de metas;

XVI. aprovar as contas do Fundo antes do seu envio aos órgãos de controle interno;

XVII. dirimir dúvidas quanto à aplicação das diretrizes e normas relativas ao FMH nas matérias de sua competência;

$X V I I I$. definir normas, procedimentos e condições operacionais;

XIX. fixar a remuneração do órgão operador do FMH;

XX. divulgar no Diário Oficial do Município as decisões, análises das contas do FMH e pareceres emitidos.

Parágrafo único: Para a função específica de acompanhamento da gestão do Fundo Municipal de Habitação, será designada uma Comissão Executiva do Conselho, formada a partir de seus membros."

CYMBALISTA e MOREIRA (2002, p. 47), ROSSETTO (2003, p. 76), MARQUES e TORRES (2005, p. 287), indicam como positiva a criação do $\mathrm{CMH}$. FERREIRA (2006, p. 216) aponta para o fato do sistema constituído pelo $\mathrm{FMH}$ e pelo $\mathrm{CMH}$ estar em conformidade com os princípios e diretrizes da Lei Federal $\mathrm{n}^{\circ}$. 11.124/05, que criou o Sistema Nacional de Habitação de Interesse Social e que 
"estabelece que, para a adesão a este Sistema, os municípios devem criar um fundo, um conselho e um plano de habitação".

As Resoluções do $\mathrm{CMH}^{48}$, desde a posse dos seus primeiros conselheiros, em $1^{\circ}$ de junho de 2003 , até o final de 2004 , foram as seguintes:

- $\mathrm{CMH} \mathrm{n}{ }^{0} .01$ - Regimento interno do CMH.

- $\mathrm{CMH} \mathrm{n}$ n$^{\circ} 02$ - Programa Carta de Crédito Municipal.

- $\mathrm{CMH} \mathrm{n}$ n. 03 - Prestação de Contas de 2002 e primeiro semestre de 2003.

- $\mathrm{CMH} \mathrm{n}{ }^{0} .04$ - Programa Bolsa Aluguel.

- $\mathrm{CMH} \mathrm{n}$ n $^{0} 05$ - Programa de Mutirão.

- $\mathrm{CMH} \mathrm{n}$ n 06 - Prorroga o prazo de incidência da Resolução CFMH no. $21^{49}$.

- $\mathrm{CMH}$ no. 07 - Regras específicas para empreendimentos destinados ao $\mathrm{PSH}^{50}$.

- $\mathrm{CMH} \mathrm{n}$ n $^{\circ} 08$ - Programa de Mutirão - revoga a Resolução CMH nº 05.

- $\mathrm{CMH} \mathrm{n}$ n$^{\circ} .09$ - Prestação de Contas do segundo semestre de 2003.

- $\mathrm{CMH}$ nº 10 - Regras para concessão de subsídios, composição do investimento e financiamento de unidades habitacionais nos programas de provisão habitacional.

- $\mathrm{CMH}$ nº 11 - Referendo de operações relacionadas a cobrança do aluguel social e pagamento de contas de água e energia elétrica, nos empreendimentos Parque do Gato e Olarias do Programa Locação Social.

- CMH nº. 12 - Alteração da Resolução CFMH no. 2351.

- $\mathrm{CMH} \mathrm{n}$ n$^{\circ} .13$ - Prestação de Contas do primeiro semestre de 2004

- $\mathrm{CMH} \mathrm{n} \mathrm{n}^{\circ} .14$ - Procedimentos de prestação de contas dos recursos do $\mathrm{FMH}$, operado pela COHAB/SP.

- $\mathrm{CMH} \mathrm{n}$ n$^{\circ} 15$ - Programa de Cortiços - Reabilitação da Moradia Coletiva.

\footnotetext{
${ }^{48}$ FERREIRA, Luiz Paulo Teixeira, 2006, p. 228

49 Resolução que trata da "Definição dos procedimentos operacionais relativos à regularização do acesso às unidades habitacionais vinculadas ao FMH e não comercializadas, habitadas ou não, e daquelas em construção a serem concluídas até 30 de junho de 2004".

50 Programa de Subsídio para Habitação de Interesse Social, do Ministério das Cidades.

${ }^{51}$ Resolução que normatiza o Programa de Locação Social.
} 
Mas além dessas resoluções, ele deliberou sobre um conjunto de outras questões também relevantes, tais como:

- O Plano de Metas que Ihe foi enviado em sua primeira reunião ordinária;

- A doação dos Edifícios São Paulo e São Vito ao Fundo de Arrendamento Residencial (FAR), para viabilizar sua reforma pelo Programa de Arrendamento Residencial (PAR);

- A remuneração da COHAB em empreendimentos de HIS relativos à Operações Urbanas.

Em relatório para a FAUUSP ${ }^{52}$, a Dra. Maria Lúcia Refinetti Martins, professora dessa escola e representante da USP no $\mathrm{CMH}$, observou que:

"Entre a posse e o final de 2004 o Conselho reuniu-se com regularidade e freqüência, além das 8 reuniões ordinárias, houve 8 extraordinárias, diversas reuniões preparatórias e um seminário sobre orçamento. Em 2005 houve duas reuniões ordinárias. Além disso foram diversos os Grupos de Trabalho que se organizaram para estudar assuntos específicos".

E avaliou a ação do Conselho como "muito boa" no aspecto da:

"Definição e forma de operação de determinadas políticas públicas", que considera que, "foi sem dúvida a parte que teve melhores resultados. O Conselho produziu e aprovou resoluções importantes como:

- Regulamentação dos Mutirões,

- Bolsa Aluguel,

- Programa de Cortiços,

- Forma de prestação de contas por tipo de programa e por empreendimento, apresentando recursos e o que foi produzido".

Essa professora avaliou como "ambígua" a ação do $\mathrm{CMH}$ em relação a algumas questões, pois segundo ela:

"Em diversas situações foram apresentadas ao Conselho para deliberação situações onde as opções se caracterizavam como "administrar o prejuízo", por exemplo: autorizar o Executivo a admitir uma perda ou um afastamento das efetivas prioridades, para evitar uma perda maior. Isso ocorreu em diversas

52 www.usp.br/fau/fau/direcao/congregacao/index.html 
situações, incluindo aditamento de recursos para determinados empreendimentos para fazer frente a equívocos de projeto e/ou de avaliação de gestões anteriores ou mesmo por aumento de custos decorrentes de obra paralisada".

E ainda avaliou como "insuficiente" a atuação do CMH quanto:

"A efetiva participação do Conselho na decisão de grandes prioridades, quais sejam: que percentual aplicar em cada tipo de Programa, quais os beneficiários; que parte dos recursos destinados a habitação entra no Fundo Municipal ou fica na SEHAB; impactos do Planejamento sobre a Política de Habitação - tanto no que diz respeito a grandes diretrizes (por exemplo, Plano Diretor) quando à utilização dos recursos do Fundo de Desenvolvimento Urbano (decorrente da outorga onerosa), à exigência de priorizar HIS na utilização de recursos das Operações Urbanas".

O funcionamento do $\mathrm{CMH}$ de forma com que exerça plenamente as suas atribuições, a efetivação dos propósitos que motivaram sua constituição é uma coisa em construção, que demanda não só a boa vontade dos conselheiros e da Administração Pública, mas também um aprendizado dos vários atores envolvidos.

Certamente entre 2003 e 2004 e, de acordo com algumas informações obtidas, ainda até hoje, o CMH não conseguiu realizar parte das tarefas que são de sua competência, tais como: "convocar a Conferência Municipal de Habitação" e "participar da elaboração do plano de aplicação dos recursos financeiros oriundos dos Governos Federal, Estadual, Municipal ou repassados por meio de convênios internacionais e consignados na SEHAB". E em relação a isso, a responsabilidade maior é do executivo municipal.

$\mathrm{O} \mathrm{CMH}$ ainda não tem participado tão intensamente quanto a Lei $\mathrm{n}^{\circ}$. 13.425/02 determina, das definições sobre a aplicação da totalidade dos recursos para habitação de interesse social que são destinados à SEHAB. Apesar de a ele ter sido apresentada a proposta orçamentária feita pela SEHAB em 2004, a sua participação mais intensa tem ficado circunscrita à definição da aplicação dos recursos do $\mathrm{FMH}$.

Do total dos recursos alocados pelo Tesouro Municipal para a SEHAB em 2004, os recursos do $\mathrm{FMH}$ constituíam $24 \%$ e os de outras rubricas $76 \%$. A 
utilização dos recursos das outras rubricas continua a ser resultado de decisões das instâncias técnicas e da direção da SEHAB, mas que também são, em boa medida, determinadas por amarrações contratuais. Por exemplo, os contratos de financiamento com o BID para a execução do PROVER, cujos recursos, se passassem pelo $\mathrm{FMH}$, exigiriam que a COHAB fosse a operadora. Isso não permitiria, por exemplo, a continuidade dos contratos firmados com a SEHAB/HABI com empreiteiras e gerenciadoras, apesar de que facilitaria a comercialização pela COHAB após a conclusão das obras. Os empreendimentos do PROVER precisam de autorização legislativa para sair do patrimônio da PMSP e entrar no patrimônio do $\mathrm{FMH}$, por este último estar vinculado à COHAB e não à administração direta. E só assim, podem ser comercializados pela COHAB. Até o momento, apenas 4 desses empreendimentos passaram para o $\mathrm{FMH}$, puderam ser comercializados e têm mutuários pagando prestações com retorno para o Fundo.

Quanto a essa questão, Rossella ROSSETTO (2003, p. 76) afirma:

“Em relação ao modelo atual, podemos ver que, independentemente, do FMH, a Prefeitura continua a produzir e a investir em moradia popular, mas só haveria sentido estar fora do Fundo apenas os programas que não prevêem a comercialização, a permissão de uso onerosa ou mesmo a locação social. Nestas três situações, o financiamento da unidade e a previsão de retorno das prestações indicariam o Fundo como a melhor solução."

Ainda ponderando sobre as questões colocadas pela Conselheira Maria Lúcia Refinetti Martins, em relação ao que chama de "administrar o prejuízo", cabe reconhecer que, de fato, o $\mathrm{CMH}$ foi solicitado a autorizar modificações em atributos de grande número de empreendimentos anteriormente já aprovados. Tais modificações, na maioria das vezes, referiam-se a aditamentos de contratos e convênios para alteração de valor. Mas cabe também lembrar que houve um grande esforço no período 2001-2004 ${ }^{53}$, para subsidiar as decisões, primeiro, do CFMH (Conselho do Fundo Municipal de Habitação) e, depois, do CMH com informações que refletissem um correto planejamento do conjunto de programas e

\footnotetext{
${ }^{53}$ Tal período foi acompanhado por este autor, como um dos representantes da $\mathrm{COHAB}$ no CFMH e no $\mathrm{CMH}$ e um dos responsáveis por fornecer informações relativas aos empreendimentos, suas características e recursos que demandavam. Não se pretendeu, neste trabalho, analisar se procedimentos semelhantes, foram adotados antes e depois desse período.
} 
empreendimentos. E que, para esse planejamento de médio prazo (até 5 anos), que configurou os Planos de Metas, buscou-se:

- reunir todo o conjunto de empreendimentos que se podia prever que onerariam o FMH;

- estimar corretamente os valores envolvidos e os prazos de execução;

- totalizar os valores e ajustar os totais a um fluxo de entrada de recursos no Fundo que se julgava viável.

No período 2001-2004, foram apresentadas três propostas de Plano de Metas, que foram sendo aperfeiçoadas. A primeira e a segunda foram aprovadas pelo CFMH, respectivamente, em 29/10/2001 e 12/06/2002, e a terceira aprovada pela Comissão Executiva do $\mathrm{CMH}$ em sua 1ª. Reunião Ordinária, 21/07/2003.

A elaboração desse planos era muito complexa, pois envolvia uma grande quantidade de itens e aspectos. Era grande o número programas, empreendimentos, contratos e convênios, chegando a 168 a soma dos dois últimos (muitos empreendimentos continham mais de um contrato ou convênio). Havendo muitas possibilidades de variações ao longo do tempo, de cada um desses contratos e convênios em relação ao previsto inicialmente. Variações, principalmente, por ajustes de valor.

Mas além disso, depois de aprovado cada um desses planos, ocorreu a introdução de novos empreendimentos, como foi o caso da desapropriação e projeto de reforma do Edifício São Vito, e um novo programa, como o Bolsa Aluguel. Que demandaram remanejamento de recursos, que só foi possibilitado pela entrada de recursos inicialmente não previstos, como os do PEHP e PSH, do Ministério das Cidades, ou pela não concretização de obras do PAR o que liberou terrenos para o Programa de Mutirões com Autogestão, aliviando o FMH da previsão de despesas para a aquisição de terras.

A necessidade dessas alterações, que configuram o que se chamou de "administração do prejuízo", é difícil imaginar que seja de todo eliminada. No entanto, é possível cogitar uma redução da sua freqüência pela afinação dos instrumentos de planejamento e pela garantia de entradas de recursos por prazos mais longos, que poderia se dar, por exemplo, pelo compromisso de investimento 
em habitação de uma porcentagem fixa do total do orçamento municipal. Esse compromisso não seria feito mediante uma lei, já que a vinculação de receita, como já foi visto, é vedada pela Constituição Federal. No entanto, esse compromisso poderia ocorrer entre Executivo e Legislativo municipais, à semelhança do que ocorre entre Governo Estadual e Assembléia Legislativa, em torno da reserva para habitação de 1\% da arrecadação do ICMS.

Como já dito, a Profa. Maria Lúcia Refinetti Martins, também, considerou "insuficientes" alguns aspectos da atuação do $\mathrm{CMH}$. É preciso concordar que, efetivamente, foram "insuficientes" os aspectos relativos à participação na divisão dos recursos entre o FMH e as outras rubricas da SEHAB e os "impactos do Planejamento sobre a Política de Habitação - tanto no que diz respeito a grandes diretrizes (por exemplo Plano Diretor) quando à utilização dos recursos do Fundo de Desenvolvimento Urbano (decorrente da outorga onerosa), à exigência de priorizar HIS na utilização de recursos das Operações Urbanas". Naquilo que se refere à participação nas decisões sobre a partilha de recursos internamente à SEHAB, pode-se considerar que é uma etapa que, para ser atingida, não coloca um nível dificuldade muito alto, por se tratar de uma questão passível de ser definida no âmbito da SEHAB. Já as outras questões exigirão um bom nível de articulação do $\mathrm{CMH}$ e da SEHAB, com outras instâncias de governo: Secretaria Municipal de Planejamento (SEMPLA), quanto ao Plano Diretor, ZEIS, etc.; Empresa Municipal de Urbanização (EMURB), quanto às prioridades nas Operações Urbanas; e Conselho Gestor do Fundo de Desenvolvimento Urbano (FUNDURB). Sobre o Plano Diretor e ZEIS, um bom momento para que o $\mathrm{CMH}$ busque participar das definições em torno desses instrumentos seria o atual, em que o Plano Diretor está sendo submetido a revisão, que, pelo que se vislumbra, tende a ser feita sem que a PMSP demonstre interesse em incorporar ao debate os setores que se preocupam com HIS.

Quanto ao que considera "insuficiente" na "participação do Conselho na decisão de grandes prioridades, quais sejam: que percentual aplicar em cada tipo de Programa, quais os beneficiários", entendemos que essa "insuficiência" era devida, em grande parte, ao fato de que o conjunto de programas e empreendimentos financiados pelo $\mathrm{FMH}$, já havia sido submetido e aprovado pelo $\mathrm{CFMH}$ e já estava em andamento, antes da posse do $\mathrm{CMH}$. Mas que, se for, no mínimo, mantida a forma de apresentação de propostas e fornecimento de informações ao $\mathrm{CMH}$ que se 
verificou no período 2001-2004, ele estará, efetivamente, participando dessas decisões. 


\section{Capítulo 5 \\ A execução pela COHAB-SP da sua parte na política habitacional}

\subsection{A terras de que se dispunha e o processo de aquisição de novos imóveis para a produção habitacional}

A existência de um estoque de terras foi fundamental para o deslanche dos programas de provisão habitacional do FMH/ COHAB. No início de 2001, um dos primeiros levantamentos do estoque da COHAB estimou que as terras de que se dispunha permitiriam a implantação de 10.089 novas unidades habitacionais. Eram áreas, em sua maioria, remanescentes de conjuntos habitacionais já implantados e não incluíam as grandes glebas ainda não parceladas do patrimônio da COHAB.

Essas grandes glebas totalizavam, aproximadamente, $20.000 \mathrm{~m} 2$ (COHAB, "Relatório de Gestão 2001-2004", 2004, p. 68), mas não foram consideradas como passíveis de utilização num prazo curto, pois demandariam estudos de viabilidade e projetos de parcelamento muito complexos. Um dos casos era o Itaquera 1D, que se tratava de uma área situada em frente à Estação Itaquera do Metrô, ao lado da qual se previa a construção de um shopping center, e, portanto, um terreno de alto valor, com vocação para o atendimento a famílias de renda média. Outra grande área era a do Carmo, para a qual um eventual parcelamento teria que superar obstáculos consideráveis, principalmente, pelo fato de uma grande parcela sua ter sido incluída na APA do mesmo nome.

Posteriormente, para o Itaquera 1D foi elaborado e aprovado um projeto de parcelamento, destinado a famílias de renda média. O projeto todo (parcelamento e, principalmente, edificações) foi considerado exemplar, inclusive, premiado pela ABC (Associação Brasileira de COHAB's). Mas suas obras, apesar de já iniciadas na gestão de Marta Suplicy, com a execução da terraplanagem, não tiveram prosseguimento na gestão de José Serra. 
Esse levantamento do estoque de terras, também, considerava que havia terras com potencial para 5.356 novas uh's de propriedade da Prefeitura, que poderiam ser destinadas aos programas habitacionais. Dessa forma, as terras disponíveis permitiriam a implantação de 15.445 novas uh's (soma do potencial das terras da COHAB e da PMSP). O levantamento das terras da PMSP resultou tanto de um trabalho da SEHAB e da COHAB, quanto de uma colaboração de várias outras secretarias municipais com a SEHAB (SEMAB, SEMPLA, SMT, SIURB, etc,), num reconhecimento da gravidade do problema da habitação.

Tabela 5.1 - Terrenos da COHAB e da PMSP disponíveis em 2001 e no.potencial de UHs

\begin{tabular}{l|r}
\hline Terrenos COHAB & No. UH \\
\hline José de Anchieta - Itaquera IA & 516 \\
\hline Manoel da Nóbrega - Itaq. IB & 456 \\
\hline Manoel de Paiva - Itaquera IC & 266 \\
\hline Teotônio Vilela & 344 \\
\hline Teotônio Vilela & 300 \\
\hline José Bonifácio (I,II, III, IV) & 1.242 \\
\hline José Bonifácio (I,II, III, IV) & 1.220 \\
\hline Santa Etelvina I -VI A & 800 \\
\hline Santa Etelvina II A & 360 \\
\hline Santa Etelvina VII & 200 \\
\hline Santa Etelvina II B & 40 \\
\hline Inácio Monteiro & 360 \\
\hline Barro Branco I & 300 \\
\hline Barro Branco II - Força do Povo & 730 \\
\hline Sìtio Conceição & 420 \\
\hline Prestes Maia & 80 \\
\hline Adventista & 236 \\
\hline Valo Velho I & 160 \\
\hline Valo Velho II & 440 \\
\hline Jardim Antártica & 80 \\
\hline Raposo Tavares & 614 \\
\hline Jd. Educandário & 120 \\
\hline Pq. Boa Esperança & 160 \\
\hline Heliópolis - Gleba N & 258 \\
\hline áreas do metrô & 387 \\
\hline sub-total CoHAB & 10.089 \\
\hline
\end{tabular}

\begin{tabular}{l|r}
\hline Terrenos PMSP & No. UH \\
\hline Monet & 140 \\
\hline Estr. dos Pereiras - Paulo Freire & 200 \\
\hline e Unidos Venceremos & 60 \\
\hline Minas Gás - Bela Vitória & 157 \\
\hline City Jaraguá - City Jaraguá & 120 \\
\hline Jardim Marabá - Che Guevara & 664 \\
\hline Parque Europa I - União dos Nove & 160 \\
\hline Jd. Bela Vista - Jd. Bela Vista & 100 \\
\hline Jardim Celeste & 72 \\
\hline Santo Antonio Pq. Otero & 400 \\
\hline Inácio Monteiro & 440 \\
\hline Av. Presidente Wilson & 425 \\
\hline Lidiane & 450 \\
\hline Jd. São Carlos & 168 \\
\hline Parque da Conquista & 120 \\
\hline Jd. Maraial/Jd. Nordeste & 700 \\
\hline S. Francisco/Morro do Urubu & 320 \\
\hline City Jaraguá & 250 \\
\hline SEMPLA - Pq. Raposo T. & 160 \\
\hline SEMPLA - Minas Gás & 100 \\
\hline SEMPLA - área do Carmo & 150 \\
\hline SEMPLA - FÓ/Cruz das Almas & $\mathbf{5 . 3 5 6}$ \\
\hline sub-total PMSP & 15.445 \\
\hline TOTAL &
\end{tabular}

Fonte: Relatórios Gerenciais COHAB - 2001 
Além das terras de que já se dispunha, iniciou-se um processo de prospecção de novas áreas visando sua aquisição. Nesse processo, foram estudadas 606 áreas, com superfície total de 672,56 ha., para atendimento a programas do $\mathrm{FMH}$, e 137 áreas, com superfície de 94,57 ha., para viabilizar reassentamentos relacionados às Operações Urbanas Água Espraiada, Faria Lima, Rio Verde-Jacú (COHAB, 2004, p. 69-70).

No período 2001-2004, a COHAB obteve da Procuradoria Geral do Município (PGM), parecer favorável a sua solicitação de que fosse autorizada a mover ações de desapropriação. Conforme Maria da Graça P. SILVA (2004, p. 55), pela Lei Municipal $n^{\circ}$. 6.738/65, que autorizou a criação da COHAB, essa companhia havia recebido a prerrogativa de efetuar desapropriações, para empreendimentos habitacionais financiados pelo Governo Federal. Segundo essa autora, nos termos em que essa prerrogativa foi concedida, já se evidencia a vinculação à "Política Habitacional instituída a partir de 1964". Mas a COHAB, antes do período 20012004, havia utilizado esse instrumento apenas duas vezes, para desapropriar as áreas denominadas Sônia Ingá e Pires do Rio, que foram destinadas ao Programa de Mutirões com Autogestão de HABI/SEHAB.

Antes desse parecer da PGM, visando a compra de prédios, a COHAB$\mathrm{SP}$, inicialmente, havia estudado as possibilidades de aquisição com dispensa de licitação, com base na Lei Federal $8.666 / 93^{54}$, e, posteriormente, estudado e começado a formular um edital de licitação. Ambos os estudos demandaram muito trabalho da Companhia e a necessidade de se definir os procedimentos mais corretos para a aquisição de prédios foi a principal dificuldade enfrentada para o início dos empreendimentos que envolviam reforma de prédios do Programa Morar no Centro. No processo de definição de um procedimento viável para a aquisição de prédios, perdeu-se a oportunidade da venda do edifício da Rua Assunção, que havia sido objeto dos estudos mais avançados feitos pelo GTAl (Grupo Técnico para a

\footnotetext{
54 A lei mencionada rege a execução de licitações e contratos pela administração pública e, no seu Artigo 24, Inciso X, prevê a possibilidade de dispensa de licitação: "para compra ou locação de imóvel destinado ao atendimento das finalidades precípuas da Administração, cujas necessidades de instalação e localização condicionem a sua escolha, desde que o preço praticado seja compatível com o praticado no mercado, segundo avaliação prévia".
} 
Análise de Imóveis), ligado à Coordenadoria da SEHAB para o Programa Morar no Centro, e em parceria com a Cooperação Francesa.

A partir de tal parecer da PGM, foram emitidos 13 Decretos de Interesse Social (DIS) e desapropriados 6 terrenos, com 71 ha. e potencial para 1.000 uh's. E também iniciadas desapropriações de 8 prédios na região central, visando a sua reforma e reconversão para HIS. Esses 8 prédios envolviam $65.881,64 \mathrm{~m}^{2} \mathrm{e}$ potencial para 1.073 uh's.

Segundo o Relatório de Gestão 2001-2004 (COHAB-SP, 2004, p. 69):

"A Companhia optou por fazer desapropriações negociadas, ou desapropriações amigáveis, nas quais as partes interessadas estabelecem, nos autos judiciais, acordos prévios, com base nos laudos de avaliação. Este procedimento, além de propiciar economia de recursos, permitiu a disponibilização quase imediata dos imóveis desapropriados ao poder público."

Conforme de certa maneira já foi dito, a disponibilidade de um estoque de terras pela COHAB, no início de 2001, foi uma das grandes vantagens com que contou a gestão que se iniciou naquele ano. A dificuldade para obtenção de áreas livres ou de prédios para reforma é um dos maiores obstáculos para a produção de HIS. As áreas livres com dimensões e características adequadas para empreendimentos habitacionais são cada vez mais raras e caras no Município de São Paulo e em sua Região Metropolitana.

Por outro lado, existem áreas bem localizadas, que foram utilizadas por indústrias e que hoje estão desocupadas, mas sobre as quais pairam dúvidas sobre a ocorrência de alguma contaminação. Essas áreas, no geral, demandarão estudos especiais e, eventualmente, trabalhos de remediação, como o que está sendo feito no empreendimento Nossa Senhora da Penha, do Programa de Mutirões com Autogestão da COHAB/FMH; onde se detectou contaminação do solo e ocorrência de gases, apesar de parecer favorável da CETESB, emitido na década de 80, vinte anos antes de se constatar a contaminação. A COHAB também teve que efetuar dois outros trabalhos, que envolveram estudos e contratação de laudos, relativos a suspeita ou efetiva ocorrência de contaminação nas áreas do Jardim Keralux e de um galpão do antigo IBC, de propriedade do Governo Federal, no Ipiranga (COHABSP, "Relatório de Gestão 2001-2004", 2004, p. 70) 
Em razão de ser normal uma manipulação precária de resíduos industriais e de haver uma propensão para converter áreas industriais para o uso habitacional, há uma tendência para que os agentes promotores de HIS se defrontem, cada vez mais, com problemas relativos à contaminação do solo e de águas subterrâneas, e à ocorrência de gases nos terrenos. Dessa forma, terão que se capacitar para analisar as terras que pretendam adquirir, também em relação a esses aspectos, e a especificar medidas de remediação, quando forem necessárias.

Como a maioria das terras disponíveis no mencionado estoque situava-se na Zona Leste, muitas delas em regiões muito distantes do Centro (Cidade Tiradentes, etc.), a COHAB teve que continuar a construir moradias em áreas que não atendiam, estritamente, aos requisitos de boa localização, boa inserção na malha urbana, que foram propostos no seu Planejamento Estratégico.

O Plano Diretor do MSP, aprovado em 2002, gravou um número expressivo de áreas como ZEIS (Zonas Especiais de Interesse Social). São 140 milhões de $\mathrm{m}^{2}$, que representam $12 \%$ da área urbana da cidade. Estima-se que seria possível construir 130.000 uh's ${ }^{55}$., na soma das áreas das ZEIS 2 (terrenos e glebas vazias) e das ZEIS 3 (áreas de concentração de cortiços e de imóveis desocupados/deteriorados, bem servidas de infra-estrutura e com potencial de valorização) ${ }^{56}$. Considerando que o Plano Municipal de Habitação projetou em 99.050 o número de novas uh's que será necessário produzir até 2.012, para equacionar o déficit previsto para o MSP, as áreas de ZEIS 2 e 3 seriam mais do que suficientes para atender a essa produção.

Mas, mesmo que não se confirmem as preocupações de que a atual administração municipal tende a reduzir as áreas gravadas como ZEIS, no processo em curso de revisão do Plano Diretor, a manutenção de tais áreas, por si só, não garantirá os esperados benefícios desse instrumento, dentre eles, uma redução no preço da terra. Para permitir que se disponha de terras a preços condizentes para

\footnotetext{
${ }^{55}$ PMSP/SEHAB, "Plano Municipal de Habitação", 2004, p. 72-74

56 ZEIS 1 são áreas ocupadas por favelas e loteamentos precários de baixa renda, que têm área igual a 120 milhões de m2, e ZEIS 4 são glebas vazias situadas em áreas de proteção de mananciais ou junto à reserva florestal da Cantareira, que não tenham vegetação significativa ou condições topográficas desfavoráveis, que poderiam ser utilizadas exclusivamente para o reassentamento de famílias moradoras em favelas e loteamentos precários situados nessas mesmas áreas de proteção ambiental (PMSP/SEHAB, "Plano Municipal de Habitação", 2004, p. 73)
} 
programas de provisão de HIS, é fundamental que haja por parte da PMSP uma eficiente gestão das ZEIS, de forma a se aplicar os instrumentos do Estatuto da Cidade (o Parcelamento, Edificação e Utilização Compulsórios; o IPTU Progressivo no Tempo; a Desapropriação com Títulos da Dívida Pública). E também uma atuação articulada entre os órgãos responsáveis pela política habitacional e pela regulação do uso do solo, coisa que não é tão corriqueira quanto seria desejável.

Tabela 5.2 - Desapropriação de terrenos para o Programa de Mutirões com Autogestão

\begin{tabular}{|c|c|c|c|}
\hline Imóvel & $\begin{array}{c}\text { Área do } \\
\text { terreno } \\
\text { (ha) }\end{array}$ & UH's & Situação ao final de 2004 \\
\hline Ferreirópolis & \multirow{6}{*}{71} & \multirow{6}{*}{1000} & desapropriação concluída - acordo \\
\hline Estrada Guarapiranga & & & desapropriação concluída - acordo \\
\hline Rua Nova Tuparoquera & & & desapropriação concluída - acordo \\
\hline $\begin{array}{l}\text { Rua Nova Tuparoquera } \\
\text { c/ Rua Poço da Pedra }\end{array}$ & & & desapropriação concluída - acordo \\
\hline Sapopemba & & & desapropriação em andamento \\
\hline Vila Amália & & & desapropriação em andamento \\
\hline Total & 71 & 1.000 & \\
\hline
\end{tabular}

Tabela 5.3 - Desapropriação de prédios para reforma - Morar no Centro

\begin{tabular}{l|r|r|l}
\hline Imóvel & $\begin{array}{c}\text { Área } \\
\text { construída } \\
\left(\mathbf{m}^{\mathbf{2}} \mathbf{)}\right.\end{array}$ & UH's & Situação ao final de $\mathbf{2 0 0 4}$ \\
\hline Hotel São Paulo & $10.491,00$ & 152 & desapropriação concluída - acordo \\
\hline Hotel São João & $2.089,77$ & 35 & desapropriação em andamento \\
\hline Senador Feijó & $2.280,00$ & 45 & desapropriação em andamento \\
\hline Asdrúbal do Nascimento & $3.027,46$ & 40 & desapropriação em andamento \\
\hline São Caetano & $2.076,00$ & 100 desapropriação em andamento \\
\hline Brigadeiro Tobias & $16.388,95$ & 226 & desapropriação em andamento \\
\hline Riachuelo & $8.311,46$ & 100 & desapropriação em andamento -27 ações \\
\hline São Vito & $21.217,00$ & 375 & desapropriação em andamento -477 ações \\
\hline Total & $\mathbf{6 5 . 8 8 1 , 6 4}$ & $\mathbf{1 . 0 7 3}$ \\
\hline
\end{tabular}

Fonte: COHAB-SP, "Balanço de Gestão 2001-2004", 2004, p. 71, e "Apresentação Geral da Gestão 20012004", slides, 2004 
Tab. 5.4 - Total de áreas disponibilizadas ao final de 2004

\begin{tabular}{|c|c|c|c|c|}
\hline \multirow{2}{*}{ Programa } & \multirow{2}{*}{$\begin{array}{c}\text { Áreas } \\
\text { indicadas } \\
\mathbf{N}^{\circ}\end{array}$} & \multicolumn{3}{|c|}{ Áreas viabilizadas } \\
\hline & & $\mathrm{N}^{\circ}$ & SUP. (Ha) & No UH's \\
\hline PAR - Construção & 58 & 45 & 20,13 & 4.135 \\
\hline CDHU & 48 & 41 & 17,08 & 2.489 \\
\hline MUTIRÃO $3^{\mathrm{a}} \mathrm{GER}$. & 26 & 26 & 30,61 & 4.242 \\
\hline TOTAL & 132 & 112 & 67,82 & 10.866 \\
\hline
\end{tabular}

Fonte: Slides da "Apresentação Geral da Gestão 2001-2004" 


\subsection{O desenvolvimento dos projetos}

A proposta de que fosse implantado um "novo padrão COHAB de projetos", colocada desde a primeira reunião de Planejamento Estratégico da Companhia, refletia a crítica feita aos tradicionais projetos da COHAB (Capítulo 2, Item 2.2) e a preocupação que, já há algum tempo, havia plasmado a bandeira pelo "direito à arquitetura" (BONDUKI et al, 1993, p. 11). Mas havia uma dúvida se também não se pretendia que os novos projetos fossem uma contraposição aos do Cingapura de Maluf e contribuíssem para firmar uma nova "marca", uma outra forma de atuar em relação à habitação de interesse social.

Implantados, na maioria, em lugares de grande visibilidade, em grandes avenidas, etc., erradicando favelas mesmo que (e muitas vezes) parcialmente e as substituindo por conjuntos habitacionais com desenho diferenciado daquele que havia predominado na produção da COHAB e da CDHU, os empreendimentos do Programa Cingapura haviam se tornado extremamente conhecidos e, para grande parte da população, eram vistos como uma referência, uma alternativa habitacional importante. Exemplo disso, foi a pergunta formulada por um repórter, ao Secretário da Habitação quando da apresentação do projeto da Favela do Gato, sobre se aquela seria a alternativa da prefeita Marta Suplicy ao Cingapura.

O seminário de planejamento estratégico da SEHAB encomendou à Diretoria Técnica da COHAB que propusesse uma melhor especificação do que seria esse "novo padrão de projetos". A proposta, em linhas gerais, foi apresentada e aprovada nessa mesma reunião, posteriormente foi detalhada e o "novo padrão de projetos" traduziu=se nas seguintes diretrizes (COHAB-SP, 2004, "Apresentação Geral da Gestão 2001-2004", slides):

1. "Individualização do abastecimento (água, luz e gás ) em todas as unidades habitacionais;

2. Utilização de parte da cobertura dos prédios para uso coletivo e/ou condominial, quando a existência da elevação mecânica (elevador) assim permitir;

3. Incorporação de equipamentos e melhorias para os condomínios como salão de festas e iluminação para áreas externas; 
4. Previsão de instalação elétrica, ponto eletrônico nos apartamentos e no salão do térreo (internet);

5. Aumento das áreas de iluminação e ventilação dos ambientes internos (aumento de caixilhos);

6. Exploração de espaços não construídos com tratamento paisagístico e ambiental com a incorporação de áreas para lazer e práticas esportivas;

7. Busca de uma plasticidade mais rica com a Incorporação de variáveis volumétricas e cromáticas na composição dos edifícios;

8. Buscar implantações que ofereçam um marco referencial na paisagem;

9. Desenho universal (Adequar as unidades à NBR 9050 - Acessibilidade de deficientes) com a execução de unidades habitacionais adaptadas e/ou adaptáveis quando a acessibilidade vertical assim permitir;

10.Execução de reservatório de retenção e dispersão de águas pluviais atendendo legislação municipal; quando possível a reutilização para uso condominial;

11.Maior racionalização da construção com incorporação de sistemas industrializados - utilização de estrutura metálica em parte ou no todo do projeto;

12. Estudos para incorporação de equipamentos de elevação mecânica ou entrega com preparação de instalação futura com execução de superestrutura."

Nas discussões desse seminário de planejamento, ficou claro que não estava entre as preocupações predominantes uma contraposição ao Cingapura e uma busca de que os novos projetos tivessem tanta visibilidade quanto os desse programa, disputando com eles a atenção dos moradores da cidade. Mas que se deveria buscar, sim, projetos melhor inseridos no sítio, que melhorassem a paisagem da cidade, agregando valores estéticos, que fossem desenvolvidos com uma maior responsabilidade ambiental, mas, sobretudo, que fossem bons lugares para seus moradores.

Não se tem a pretensão de se fazer, aqui, uma análise aprofundada dos projetos produzidos pela COHAB-SP, no período 2001-2004, mas algumas observações a respeito deles. 
Nesse período entre 2001-2004, foram desenvolvidas novas tipologias ${ }^{57}$ destinadas à implantação em terrenos não específicos: BAM, BFM, MOD e MV. Uma delas, a BAM -Bloco Articulado Multifamiliar-, foi desenvolvida desde o estudo preliminar. $\mathrm{E}$ as outras (BFM, MOD e MV) a partir de tipologias cujos projetos anteriormente já haviam sido elaborados, mas que necessitavam de adaptação à nova legislação de acessibilidade. Aproveitando o momento dessas adaptações, foram também efetuadas adequações ao conjunto de outros itens que compunham o que se chamou de novo padrão de projetos, listados anteriormente.

Também foram elaborados muitos projetos específicos, para empreendimentos em que se construiria em áreas livres, onde, pelo custo da terra, eram exigidas maiores densidades. E também para muitos prédios a serem reformados. A produção desse conjunto de projetos significou uma ruptura com as tradições da COHAB, que sempre havia utilizado, de forma intensa, as tipologias em "H", com pequenas variações, incorrendo na já mencionada repetição excessiva de soluções, responsável pela monotonia que se tornou uma marca dos antigos conjuntos da COHAB.

Além disso, essas tipologias habitualmente tinham seus projetos executivos desenvolvidos pelas construtoras, ao contrário do que passou a ser feito, com a elaboração dos projetos executivos por escritórios contratados pela COHAB e integrando seu acervo. Como um exemplo de como era antes, pode se citada a tentativa de $\mathrm{HABI}$, entre 89 e 92, de obter o "empréstimo" de um projeto padrão da COHAB, para responder a uma situação em que, com rapidez, teria que ser licitada a obra de conjunto habitacional, que atenderia à remoção de favelas necessária para liberar frente para a canalização do Córrego Uberaba (PROCAV-SVP). A resposta que se teve foi a de que os projetos executivos eram das construtoras e que a COHAB não os possuía.

A produção de projetos pela COHAB numericamente foi muito significativa. Com envolvimento muito intenso da sua equipe, foram desenvolvidos projetos para 122 empreendimentos, correspondentes a 11.729 uh's e a

57 O termo "tipologia" será utilizado aqui como é utilizado, geralmente, em órgãos de produção habitacional. Como projetos de edificações destinados a implantação em terrenos diversos. Ou seja, projetos desenvolvidos não para um terreno específico. 
$790.668,66 \mathrm{~m}^{2}$ de área construída total projetada ${ }^{58}$. Desses, 8 foram projetos para reconversão de prédios abandonados do Centro para HIS ${ }^{59}$. Além disso, a COHAB participou da análise dos projetos do PAR juntamente com a CEF (44 empreendimentos e 4.135 uh's).

Mas mais do que os números da produção, cabe observar as alterações significativas nas características de grande parte dos projetos desenvolvidos. Excetuando os empreendimentos do PAR-Construção, que, no geral, pouco inovaram no projeto, conforme será apontado no Capítulo 5.2, os empreendimentos dos Programas Morar no Centro e de Locação Social, e de Mutirões com Autogestão, introduziram propostas que interrompem a mesmice que se verifica na maior parte dos projetos dos agentes promotores de HIS no Brasil, depois do BNH (COHAB's, CDHU, etc.).

Mesmice que contrasta com projetos importantes feitos no período anterior ao BNH, dos quais são bons exemplos os dos IAP's, os de Affonso Reidy, de Attílio Corrêa Lima, de Eduardo Kneese de Melo, anteriores ao predomínio da lógica que esse banco contribuiu para propagar, de habitação social voltada quase que apenas às grandes escalas de produção e aos grandes lucros, ou, conforme BONDUKI, ANDRADE e ROSSETTO (1993, p. 67), de priorização "da produção em detrimento do consumo", ou seja, da ótica das empresas que produzem, em detrimento das necessidades dos usuários ou da adequação às cidades. Evidentemente, que não se propõe aqui que se ignore a necessidade de produção em grande escala (aliás, muito pelo contrário) e nem se está cogitando de produzir HIS num cenário em que não haja lucro. O que se está questionando são os momentos -infelizmente, a maioria- em que a habitação social passa a ser pautada quase que apenas por esses dois fatores (grande escala e lucro).

A preponderância dessa mesmice nos projetos foi também interrompida por um período da produção da CECAP (antecessora da CDHU), já pós-BNH, mas ainda não submetida à lógica desse banco e que, posteriormente, passou a imperar

\footnotetext{
${ }^{58}$ COHAB-SP, 2004, Balanço da Gestão 2001-2004, p. 73, e Slides da "Apresentação Geral da Gestão 2001-2004"

${ }^{59}$ Asdrúbal do Nascimento, Brig. Tobias, Riachuelo, S. Caetano, S. João, S. Paulo (antigo Hotel São Paulo), S. Vito, Senador Feijó.
} 
também nessa companhia. São exemplares desse período ${ }^{60}$, os conjuntos habitacionais Zezinho de Magalhães Prado (projeto dos arquitetos João Vilanova Artigas, Fábio Penteado e Paulo Mendes da Rocha), Serra Negra A (do arq. Abrahão Sanovics), Jundiaí A (de J. V. Artigas), Taubaté A (do escritório Bonilha Sancovski) e Piracicaba A (arq. Dan J. Antônio).

Outro momento em que a mesmice volta a ser interrompida, é com o advento de projetos elaborados por programas empreendidos por prefeituras de forma independente do SFH, de que são bons exemplos aqueles feitos por HABI/SEHAB durante a gestão Erundina ${ }^{61}$ e pelo Programa Guarapiranga durante a gestão Maluf ${ }^{62}$.

Na produção de projetos da COHAB-SP, entre 2001 e 2004, mesmo no PAR-Construção, alguns projetos apresentaram alternativas aos tradicionais edifícios em "H", predominantes na produção habitacional de órgãos como a COHAB-SP e a CDHU. Exemplo disso, são os seguintes projetos:

- José Bonifácio - projeto do $\mathrm{Arq}^{\circ}$ Paulo Giaquinto, para obra da construtora Esteto;

- S. Etelvina - implantação da tipologia MV da COHAB, em obras da construtora Delta; e

- Valo Velho II - projeto das edificações pelo escritório GTA, para obra da construtora HTR.

Mesmo compartilhando do entendimento de que, quando se aborda questões de qualidade em projeto, é necessário observar, além dos elementos estéticos (em que podem ser incluídos os aspectos de inserção na paisagem), aqueles relativos a conforto e funcionalidade; à otimização do aproveitamento do terreno e de seu entorno; à preocupação com a manutenção e seus custos; à minimização dos impactos ambientais; ao cumprimento da legislação e dos procedimentos de aprovação; à precisão e racionalidade que permite à obra e, dessa forma, pelo que contribui para que os custos sejam melhor controlados e, eventualmente, reduzidos. Mas, nestes comentários, não se pretende uma análise

\footnotetext{
60 Denise RUPRECHT (2003, p. 43)

61 BONDUKI, ANDRADE e ROSSETTO (1993); RUBANO (2001)

62 RUBANO (2001)
} 
de projeto que abranja o conjunto ou a maior parte dessas questões. Serão observados mais os aspectos relativos à forma externa, que podem ser vistos a partir de uma leitura relativamente rápida dos projetos.

Podem ser notadas algumas características marcantes, na produção de projetos da COHAB-SP, no período 2001-2004:

- As estruturas laminares/delgadas formando "L'S", "U's" ou implantadas como lâminas justapostas.

Residencial do Gato, Olarias, Pari, Belém, Bresser, Residencial São Paulo, Vilinha 25 de Janeiro.

- As estruturas laminares que oferecem, para a cidade, fachadas (tanto as internas, quanto as externas) plasticamente bem concebidas, em que se trabalhou com cuidado os volumes e cores, evitando-se chapados cheio de janelinhas E que, além disso, conformam espaços internos resguardados, pensados como pátios, praças e não como local adequado para abrigo de botijões de gás, como em muitos conjuntos de HIS.

- A lembrança dos "H's", não aqueles amesquinhados que marcaram a maior parte da produção da COHAB e da CDHU, mas os do

Olarias, Pari, Belém, Bresser, Residencial São Paulo, Vilinha 25 de Janeiro.

Residencial do Gato Zezinho de Magalhães, com grande distância entre lâminas, e introduzindo uma assimetria na posição das lâminas em relação às escadas. 
- A utilização da circulação externa horizontal, não apenas como elemento de acesso aos apartamentos, mas também como grandes varandas, locais de encontro ${ }^{63}$.

- O uso de pilotis.

- O uso de sacadas.

- Recurso à volumetria e ao cromatismo para produzir projetos diferenciados e de maior qualidade plástica.
Residencial do Gato, Olarias, Pari, Belém, Bresser, Residencial São Paulo, Valo Velho II, Vilinha 25 de Janeiro, Carlos Gomes, tipologia BAM.

Residencial do Gato, Carlos Gomes

Residencial do Gato Conjunto dos projetos

Observando os elementos que se propunha observar neste trabalho, pode-se dizer que a intenção de estabelecer um novo padrão de projetos foi bem sucedida. Que, além de se produzir um número considerável de projetos de qualidade, também se avançou na experiência sobre a forma de se lidar com o processo de produção de projetos, que pode continuar a ser utilizado e ampliado e, dessa forma, constituir uma "nova cultura" sobre o quê fazer (produtos) e como fazer (processo).

${ }^{63}$ Essa utilização dos espaços de circulação como varandas/locais de encontro retoma uma solução de projeto utilizada nos Conjuntos da Juta e Copromo (projetos da assessoria técnica Usina para mutirões da CDHU), no C.H. Parque Europa II (projeto da arq ${ }^{a}$. Helena Saia, para HABI 1989-1992). A respeito do C.H. do Copromo, Pedro ARANTES (2002, p. 218) diz: "As circulações alargavam na entrada dos apartamentos, tornando-se amplas varandas coletivas, onde os vizinhos põem suas cadeiras e sentam para conversar e admirar a obra que construíram". O arq. Wagner Germano, um dos fundadores da USINA, que ocupou a Superintendência de Planejamento e Projetos e a Assessoria da Diretoria Técnica da COHAB, entre 2001-2004, e responsável pela concepção de boa parte dos projetos da Companhia nesse período, apontava para a intenção de construir um elemento lúdico e contemplativo com a alternância das aberturas externas e internas, nos espaços de circulação horizontal, do Residencial São Paulo. 


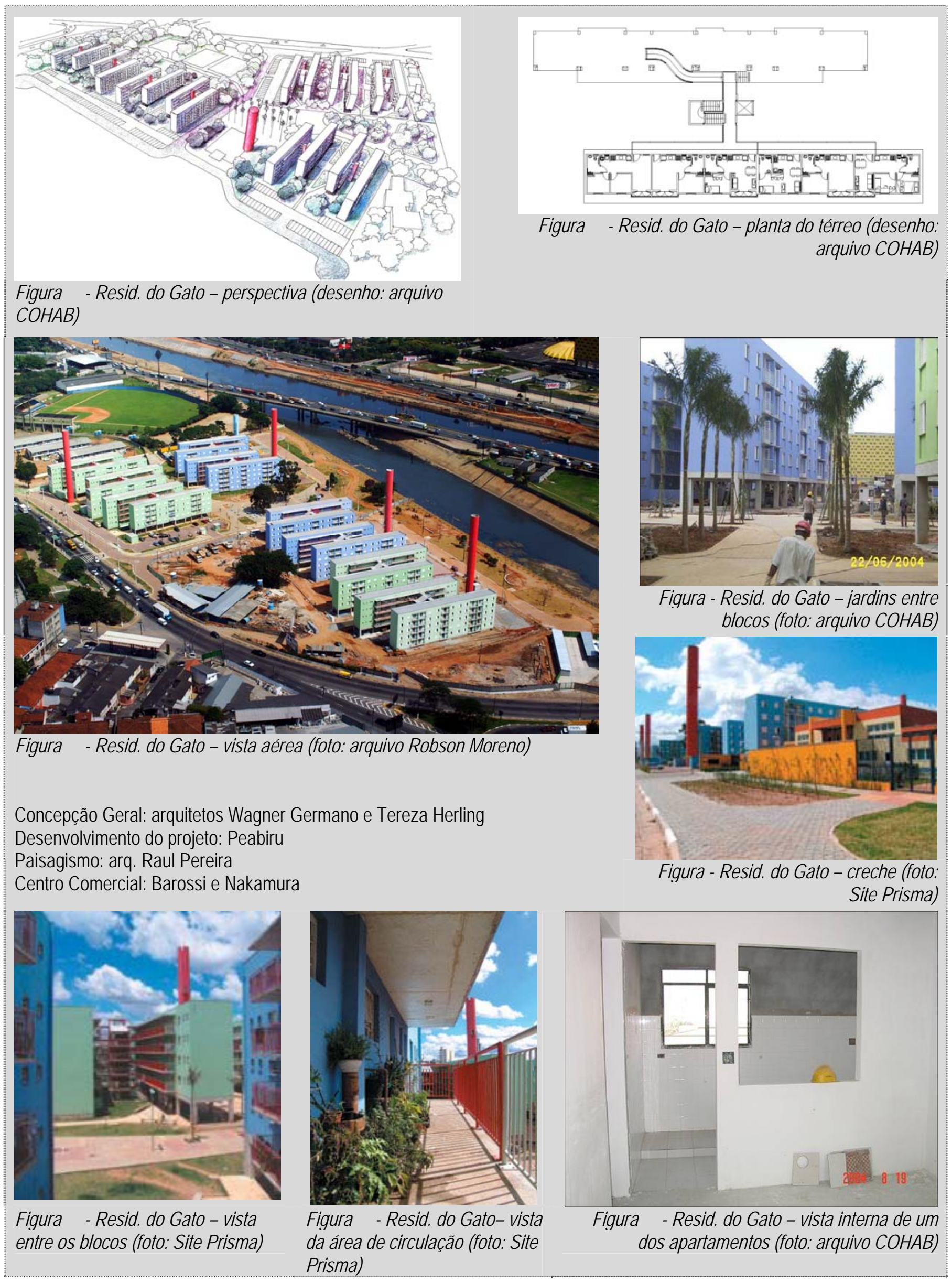




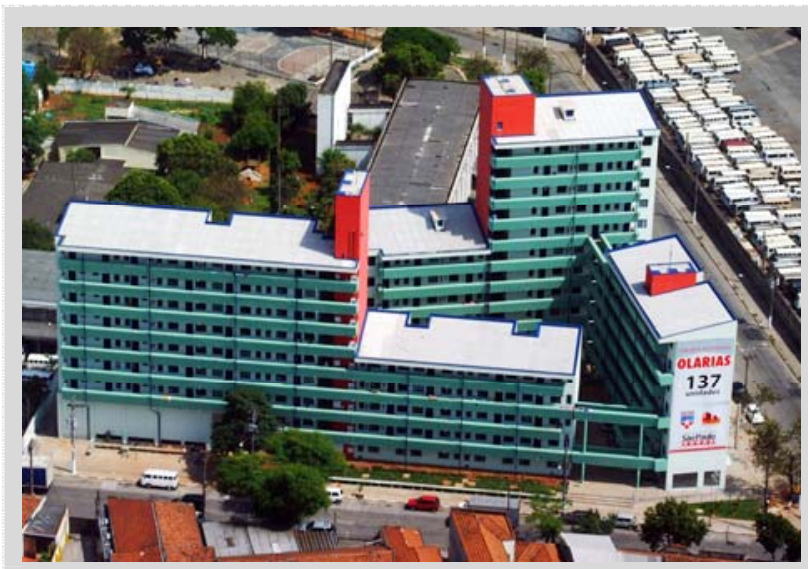

Figura - CH Olarias - Projeto Helena Saia Arquitetos Associados (foto: Robson Moreno)

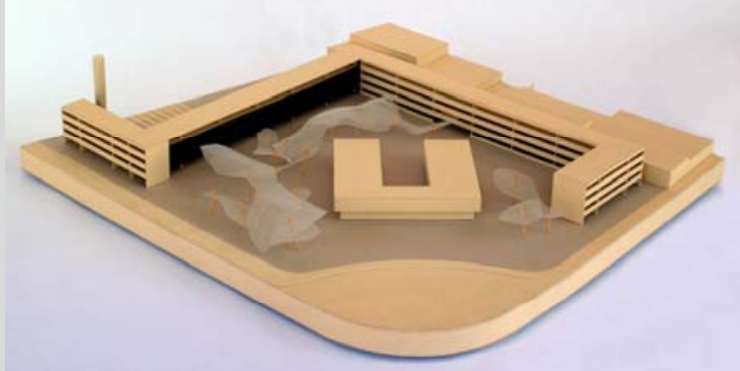

Figura - CH Pari - maquete - (foto: arquivo $\mathrm{COHAB}$ )

Projeto: arq. Hector Vigliecca

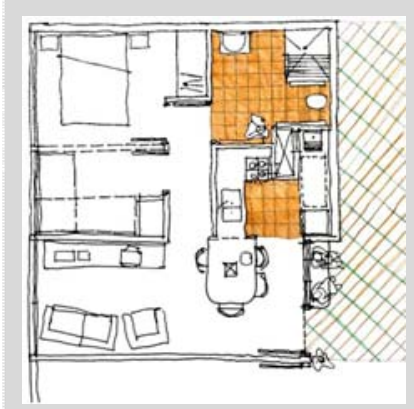

Figura - CH Pari - planta de um apartamento (desenho: arquivo $\mathrm{COHAB}$ )

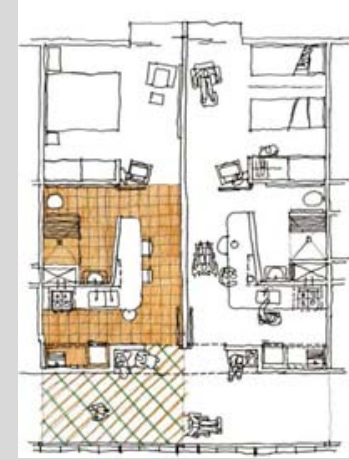

Figura - CH Pari planta de um apartamento (desenho: arquivo $\mathrm{COHAB)}$

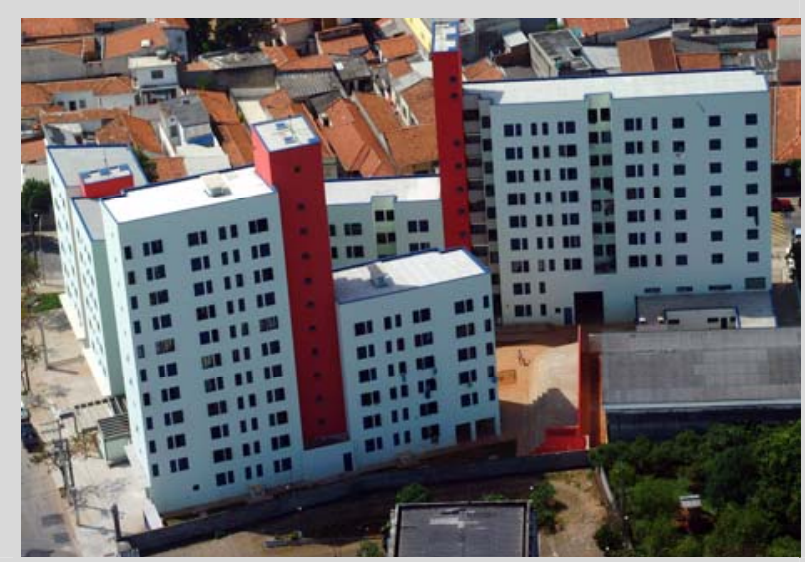

Figura - CH Olarias - Projeto Helena Saia Arquitetos Associados (foto: Robson Moreno)

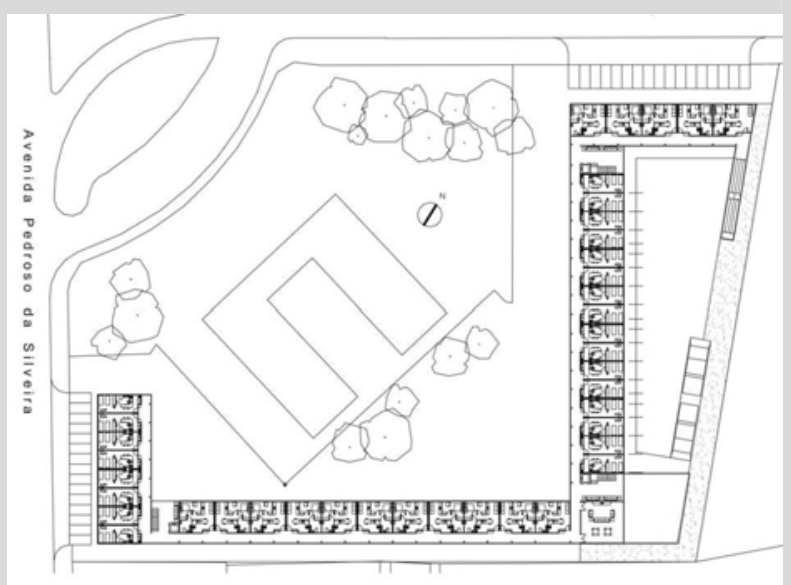

Figura - CH Pari - planta (desenho: arquivo $\mathrm{COHAB}$ )

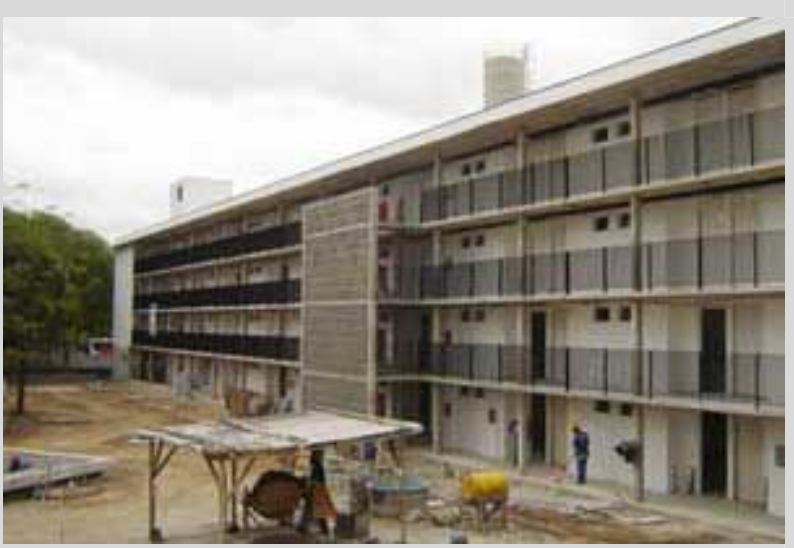

Figura - $\mathrm{CH}$ Pari - foto da obra (site COHAB) 


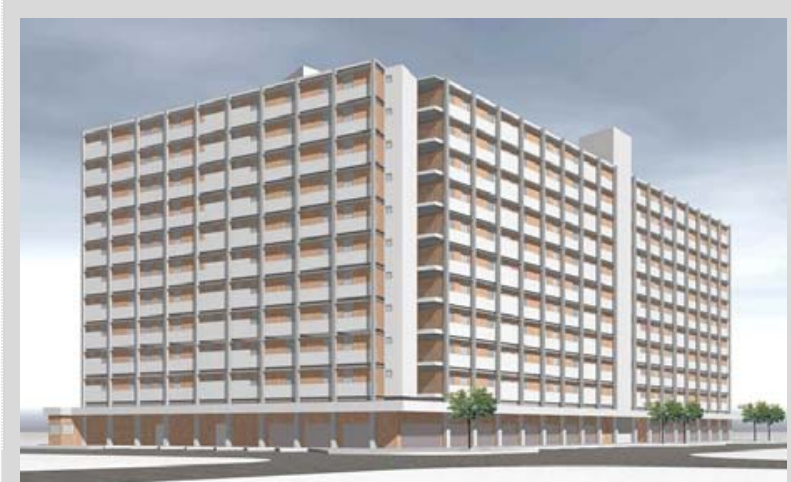

CH Metrô Belém - vista lateral - maquete eletrônica - (foto: arquivo COHAB) - Projeto Minoru Naruto

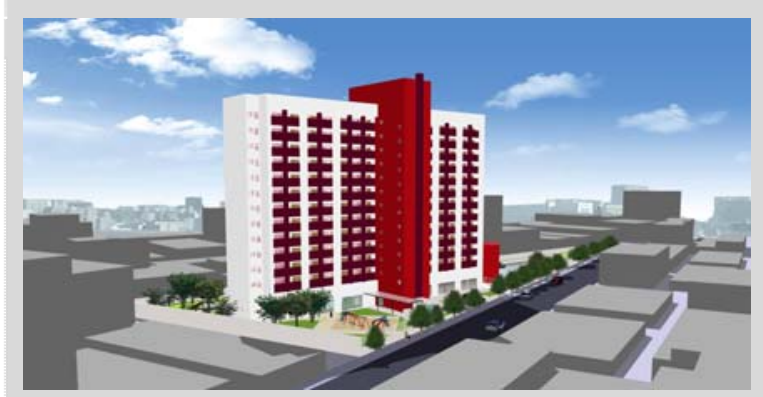

CH Bresser XIV - maquete eletrônica - (foto: arquivo COHAB) Projeto Ambiente Urbano Planejamento e Projetos

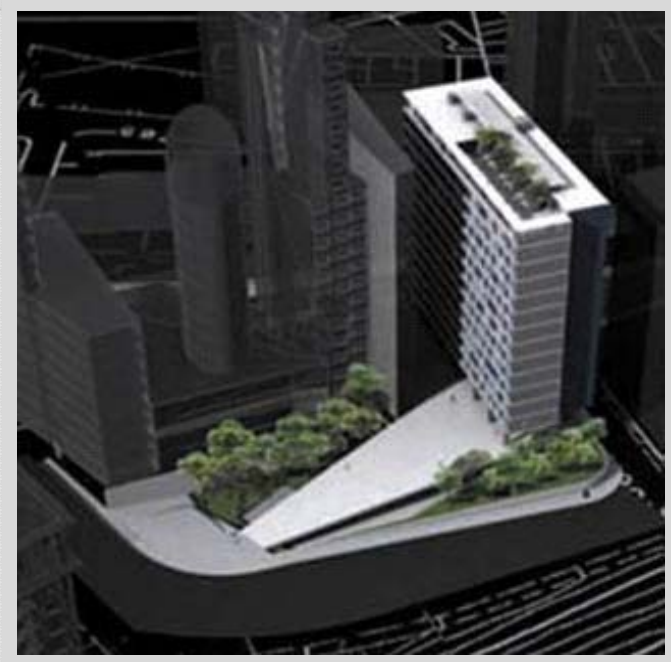

CH Assembléia - maquete eletrônica - (foto: arquivo COHAB) Projeto: Andrade Morettin Arquitetos Associados

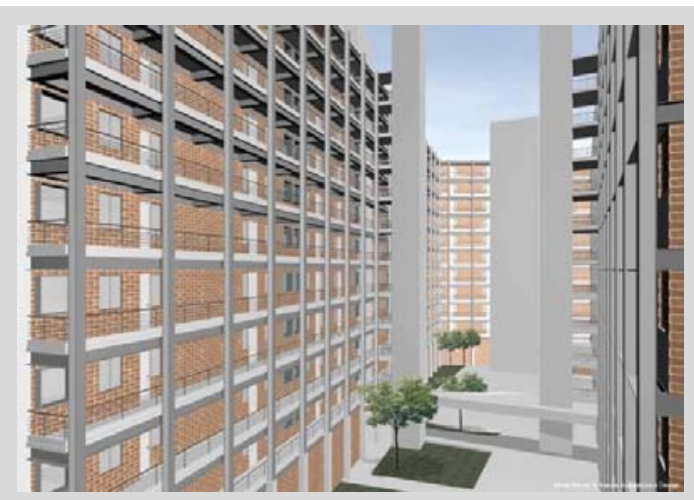

CH Metrô Belém - vista pátio interno maquete eletrônica (foto: arquivo $\mathrm{COHAB}$ )

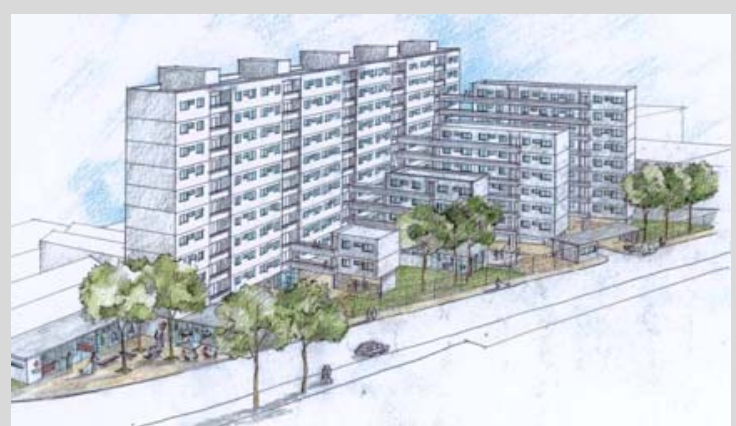

CH Bresser VI - (desenho: arquivo COHAB) Projeto arqo. Paulo Bruna

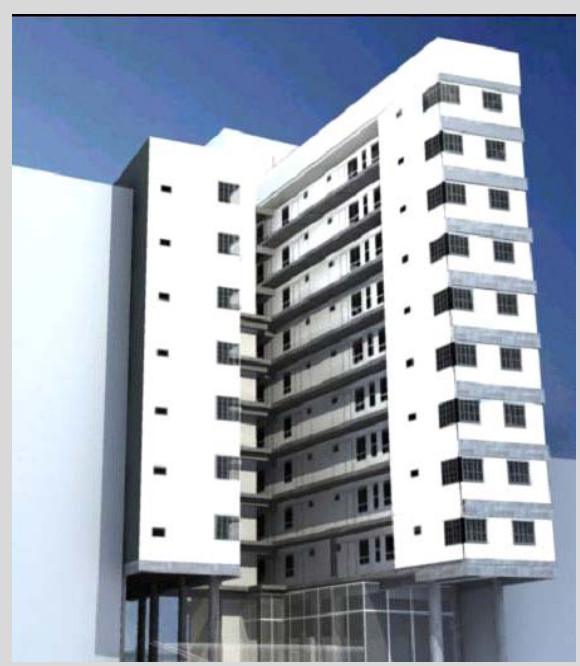

CH Carlos Gomes - maquete eletrônica - (foto: arquivo COHAB) - Projeto : Barbosa e Corbucci Arquitetos Associados 


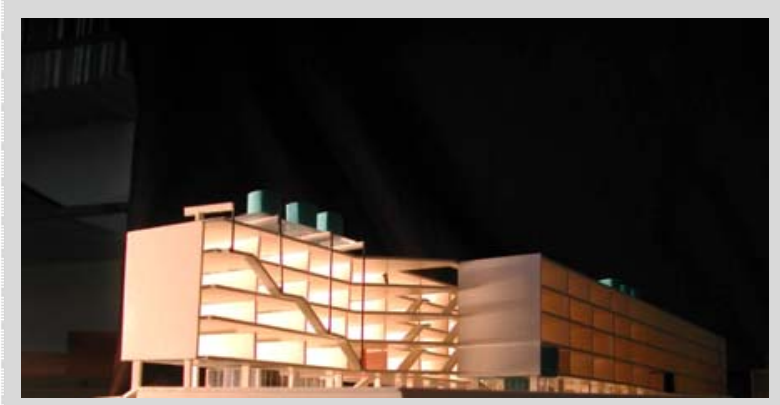

CH Cônego Vicente Marino - (foto: arquivo COHAB) Projeto: Frentes Arquitetura
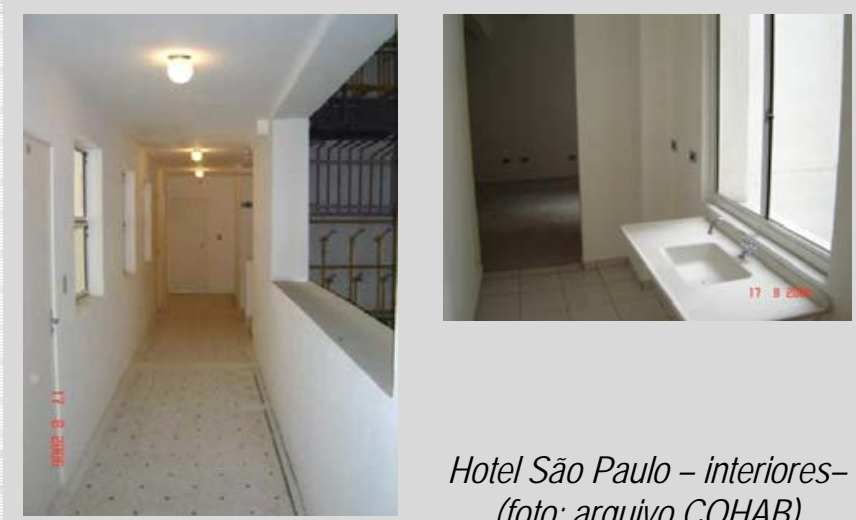

Hotel São Paulo - interiores(foto: arquivo $\mathrm{COHAB}$ )

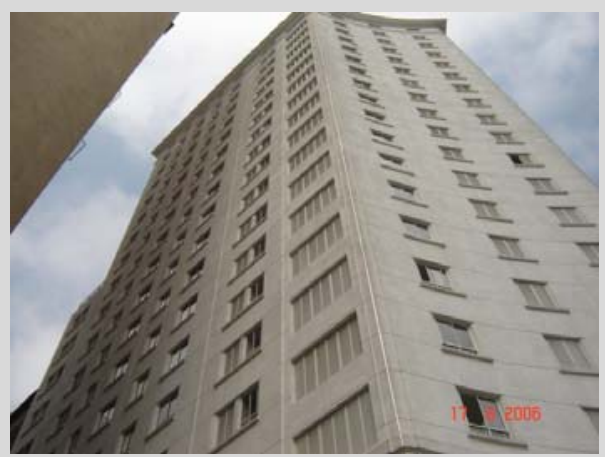

Hotel São Paulo - fachada lateral - (foto: arquivo COHAB)

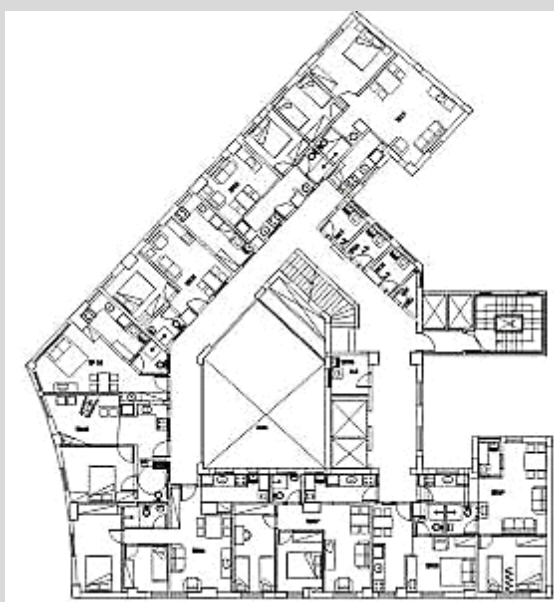

Hotel São Paulo - planta do andar tipo - (foto: arquivo COHAB)

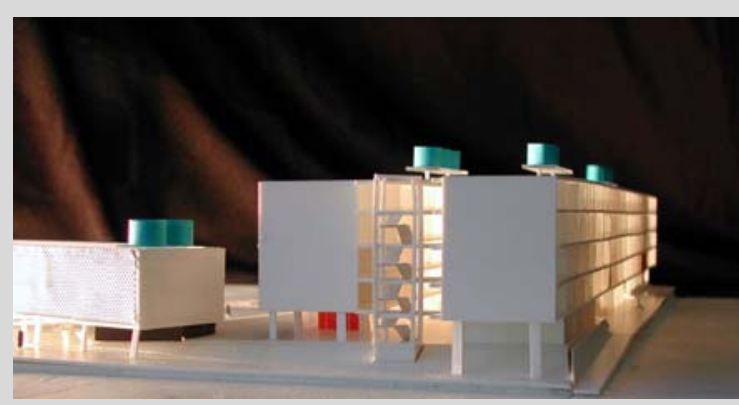

CH Cônego Vicente Marino - (foto: arquivo COHAB)

Projeto: Frentes Arquitetura

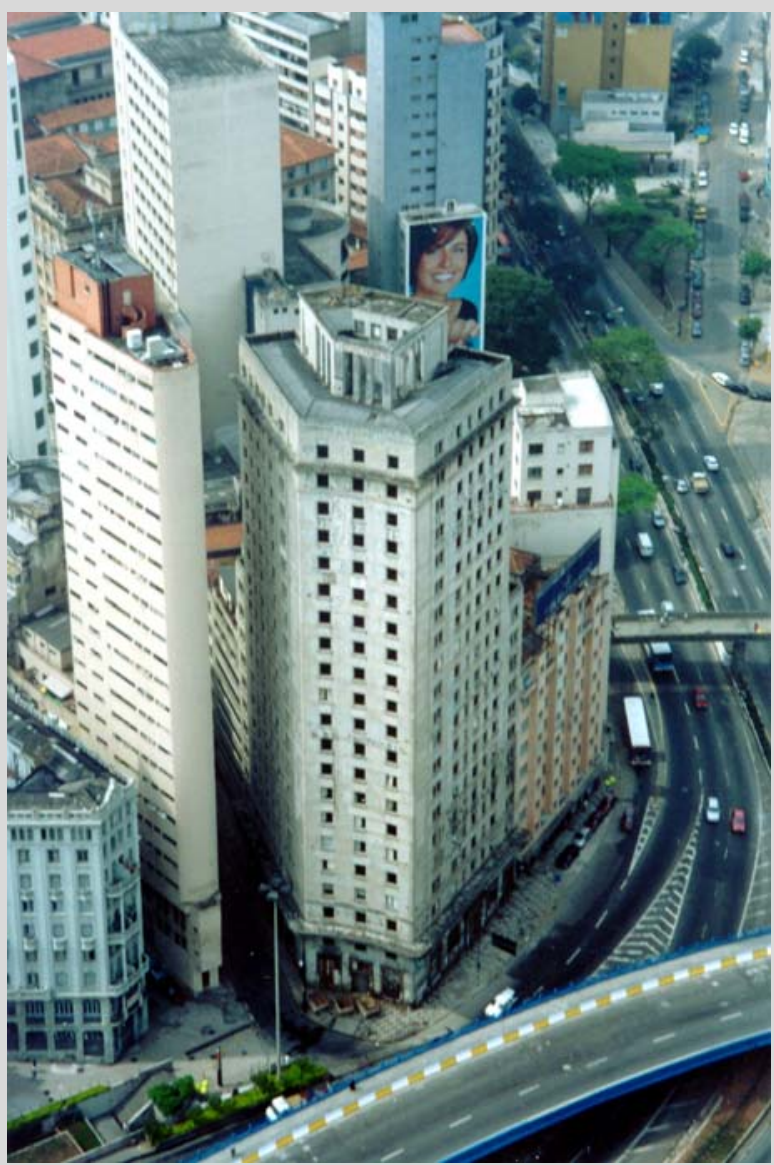

Hotel São Paulo - vista geral - (foto: arquivo COHAB Projeto: Fábrica Urbana Centro de Estudos e Projetos da Cidade 


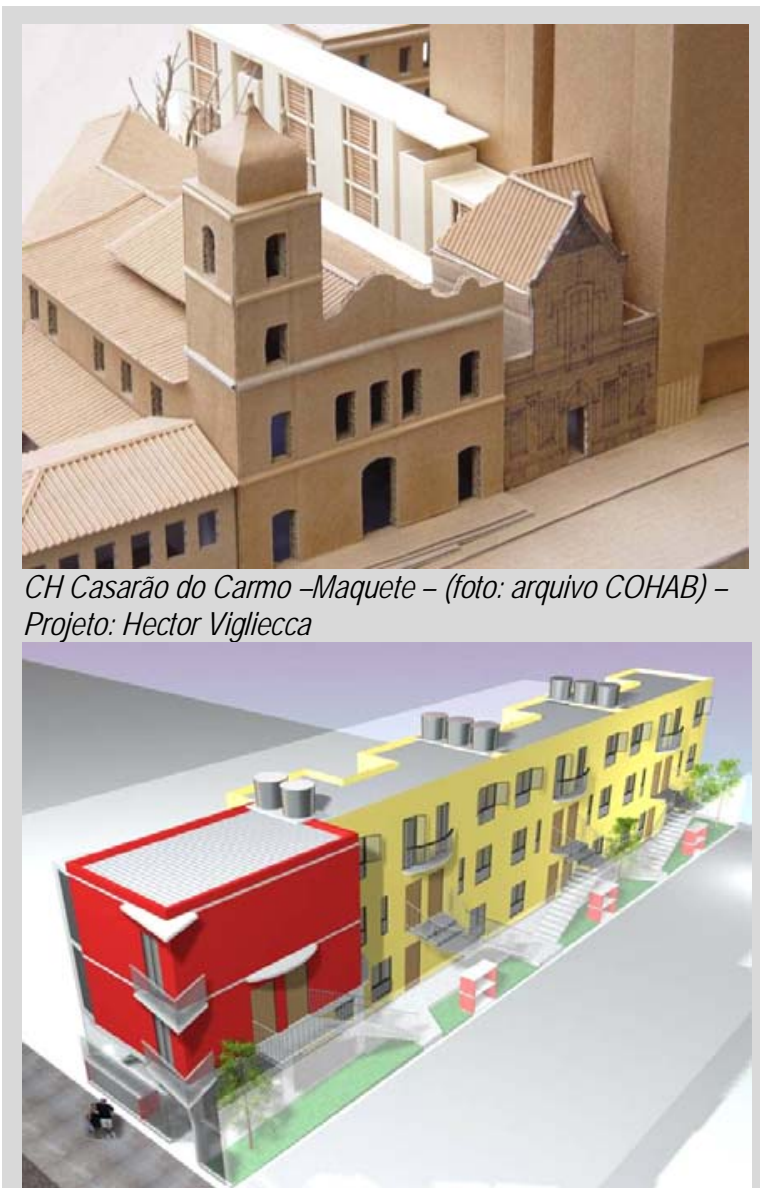

CH Pedro Facchini - maquete eletrônica - (foto: arquivo COHAB) - Projeto: Barbosa e Corbucci Arquitetos Associados

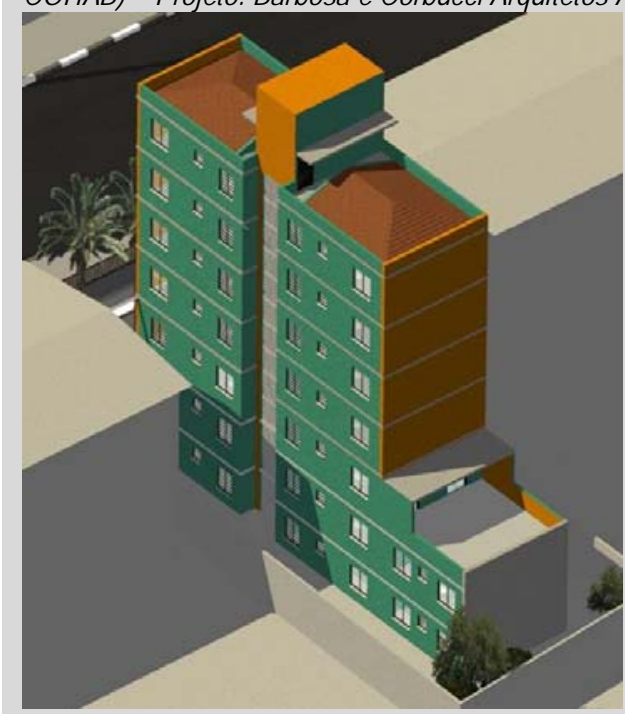

CH Eiras Garcia - maquete eletrônica -(foto: arquivo COHAB) - Projeto: Integra - Cooperativa de Trabalho Interdisciplinar

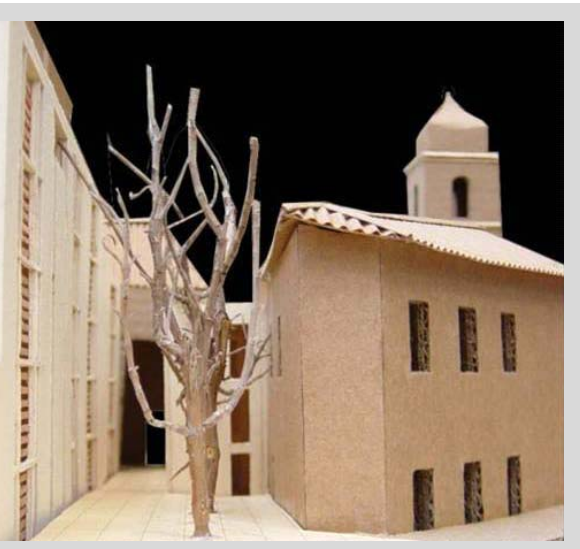

CH Casarão do Carmo -Maquete - (foto: arquivo COHAB) -

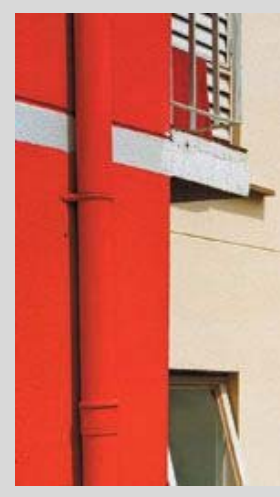
Projeto: Hector Vigliecca

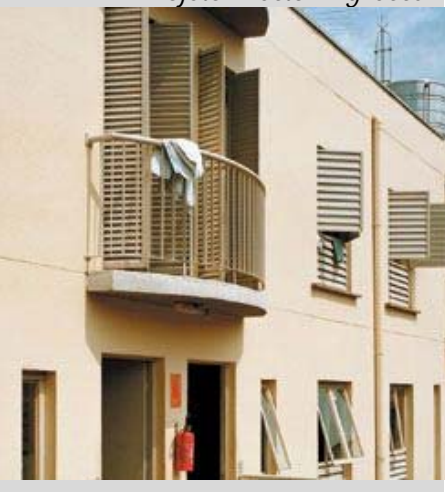

CH Pedro Facchini - maquete eletrônica - (foto: arquivo COHAB) - Projeto: Barbosa e Corbucci Arquitetos Associados

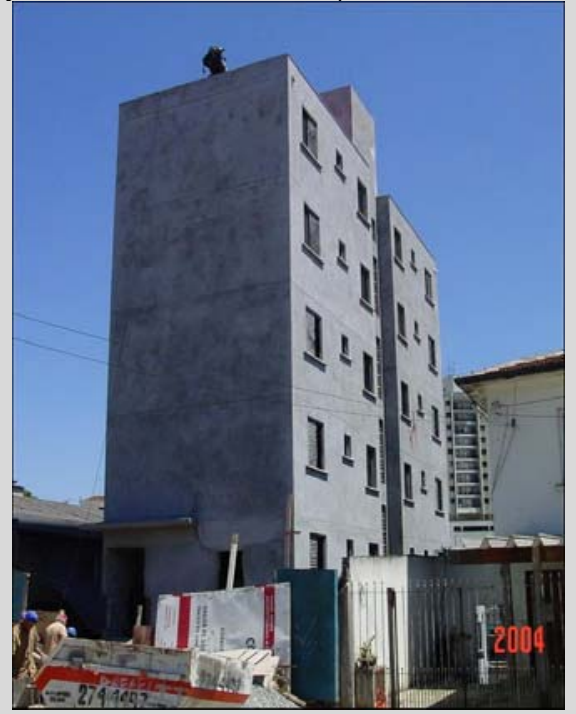

CH Eiras Garcia - execução da obra -(foto: arquivo COHAB) Projeto: Integra - Cooperativa de Trabalho Interdisciplinar 


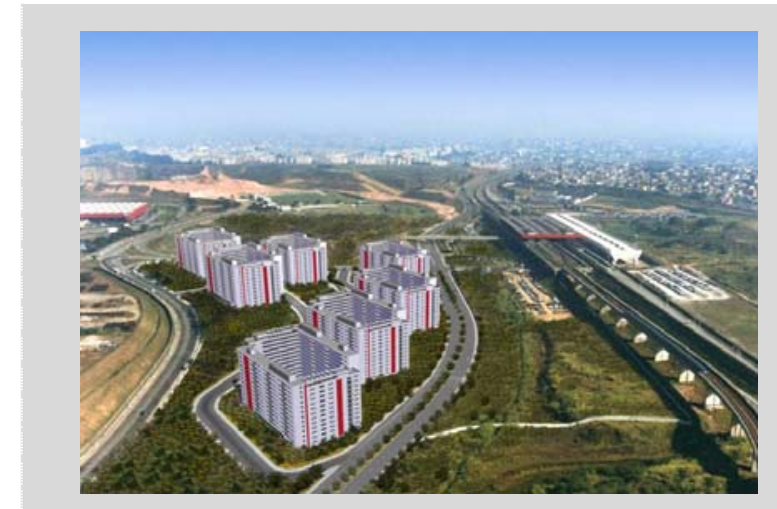

CH Residencial São Paulo - (foto: arquivo COHAB)

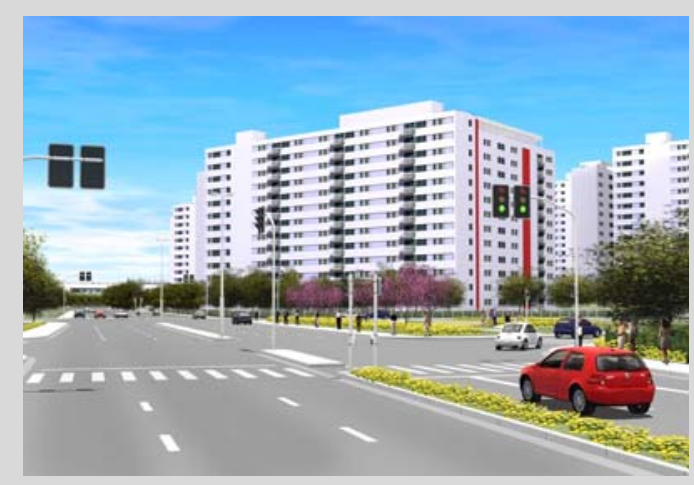

CH Residencial São Paulo - Perspectiva fachadas - (foto: arquivo $\mathrm{COHAB)}$
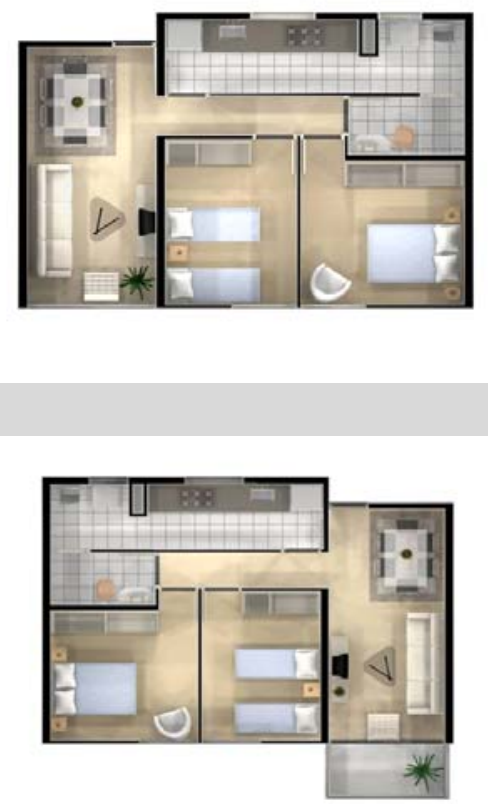

CH Residencial São Paulo - tipologias - unidades habitacionais

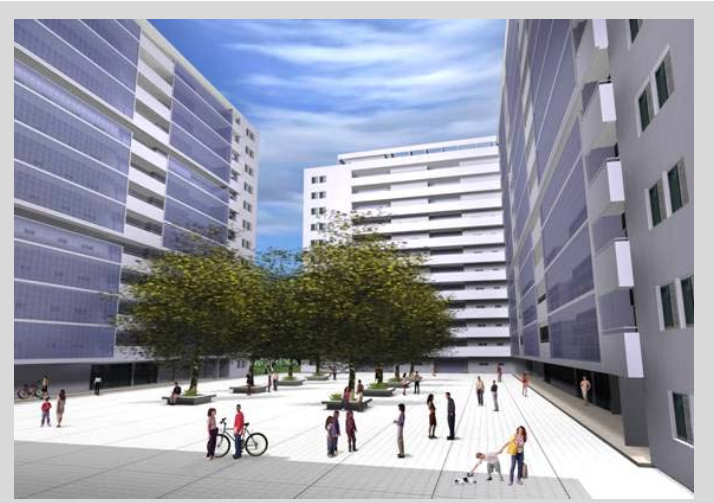

CH Residencial São Paulo - vista pátio central (foto: arquivo $\mathrm{COHAB}$

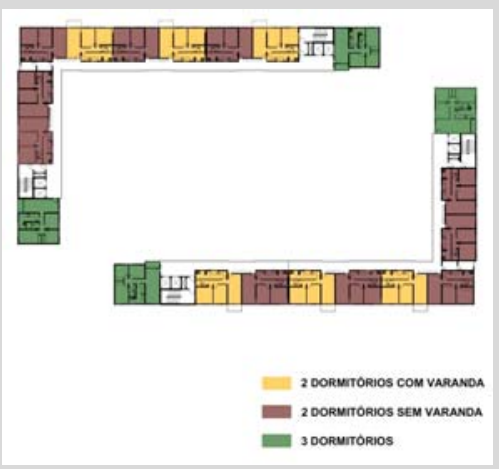

CH Residencial São Paulo - Planta implantação do edifício- (foto: arquivo COHAB)
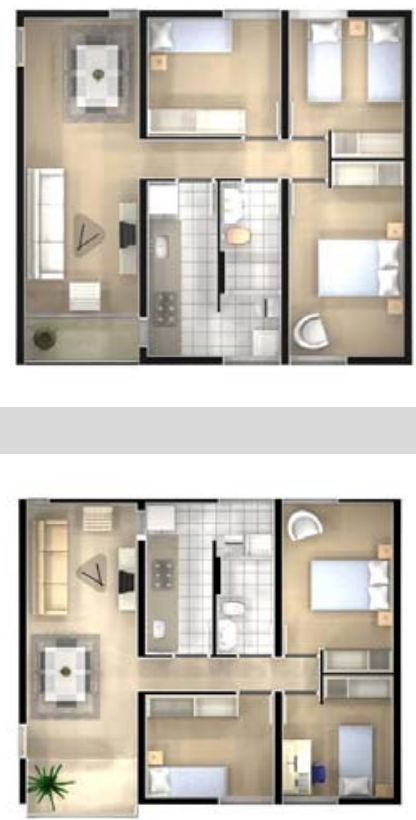


\subsection{O Programa de Mutirões com Autogestão}

O Programa de Mutirões com Autogestão caracteriza-se por possibilitar a implementação de empreendimentos com a participação de três agentes: a) associações comunitárias criadas para essa finalidade; b) assessorias técnicas contratadas pelas associações, que são os responsáveis técnicos pela execução dos projetos e obras; e c) poder público como agente financiador e fiscalizador.

No caso do programa da PMSP, a COHAB, com financiamento do FMH, firma convênios com as associações, pelos quais repassa recursos para a execução de projetos e obras de conjuntos habitacionais, de acordo com um cronograma prédefinido e com o desenvolvimento dos serviços. Essas associações, além de serem responsáveis pela contratação das assessorias técnicas, são responsáveis por indicar e organizar o grupo de famílias que trabalharão no mutirão e, depois, ocuparão as moradias construídas, são responsáveis pela gestão dos recursos repassados, administração do canteiro, aquisição de materiais e ferramentas, locação de equipamentos, contratação de mão de obra especializada, e pela prestação de contas da aplicação dos recursos repassados. As assessorias técnicas, que, geralmente, se constituem como ONG's e são escolhidas pelas associações entre aquelas cadastradas na $\mathrm{COHAB}$, são responsáveis pela elaboração dos projetos, pela orientação e acompanhamento técnico e contábil da gestão das obras, e pela realização do trabalho social.

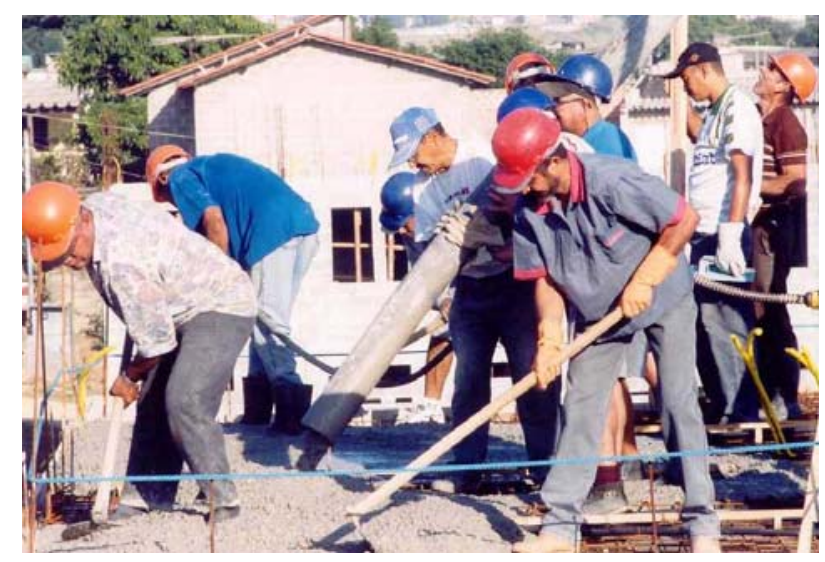

Concretagem de laje no C.H. Lapena (Arquivo COHAB-SP)

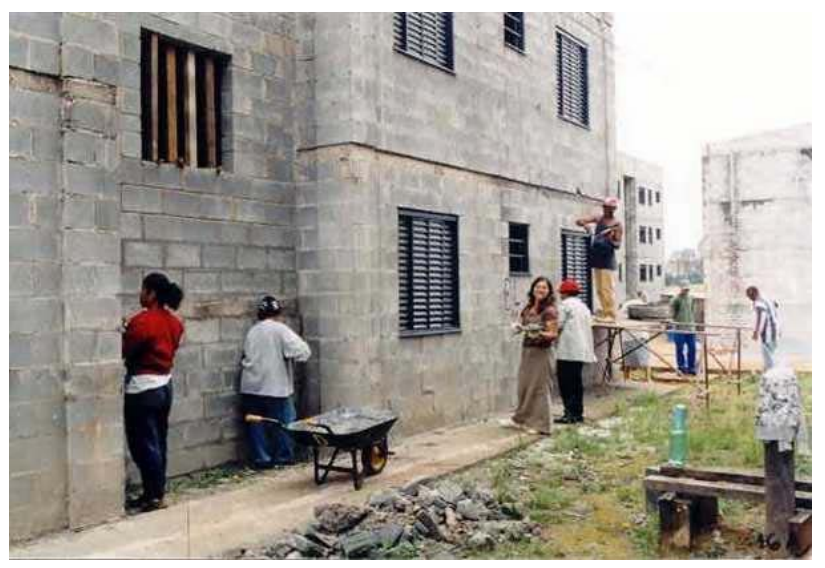

Mutirantes no C.H. Lírios do Itaim (Arquivo COHAB-SP) 
O programa de mutirões com autogestão, introduzido na Prefeitura de São Paulo durante a administração de Luiza Erundina, à época integrante do PT, talvez seja aquele, da área de habitação, com o qual mais tenham se identificado, a maioria dos técnicos de alguma forma vinculados ao partido e a maioria dos movimentos sociais. Mas, apesar de uma ampla maioria muito favorável, evidentemente, não há uma unanimidade em relação ao programa, mesmo dentro dos setores mencionados.

O grande entusiasmo pelo programa é justificado, geralmente, pelas vantagens que teria de permitir uma redução dos custos de produção, de apresentar projetos e construções de melhor qualidade, de possibilitar a participação dos futuros moradores na elaboração do projeto e na gestão da obra e, assim, por possibilitar uma melhoria do nível de consciência dos participantes das associações e representar um estímulo à organização popular. E, inclusive, por contribuir para reduzir a revenda de moradias, em razão do maior envolvimento dos moradores com a casa, que resultou do seu trabalho.

Já as críticas que esse programa recebe concentram-se em torno do sobre-trabalho; de que teria baixa produtividade; da prevalência dos critérios definidos pelas associações, no processo de seleção da demanda, em "detrimento de critérios mais universais"; de dificuldades do poder público para conter eventuais desmandos de lideranças e injustiças em relação a mutirantes (por exemplo, a exclusão do grupo não devidamente motivada) e para controlar eventuais aplicações incorretas de recursos (incorreção por desacordo com o cronograma da obra ou com o orçamento e as regras do programa), que, quando constatadas, já se tornaram fatos concretos e, dificilmente, podem ser sanadas.

Uma significativa redução de custos obtida pelos mutirões com autogestão foi apontada por muitos autores ${ }^{64}$. Ao discutir as razões dessa redução, alguns deles ${ }^{65}$ atribuem um peso considerável à administração dos empreendimentos pelas associações, inclusive maior do que o da própria

\footnotetext{
${ }^{64}$ AMARAL, 2002, p. 22; BONDUKI, 2000, p. 35; CARDOSO, 1993, p. 182; WERNA et al, 2001, p. 214, 222, 223.

${ }^{65}$ BONDUKI, 2000, p. 44; CARDOSO, 1993, p. 183; WERNA et al, 2001, p. 198.
} 
substituição da mão-de-obra contratada por mão-de-obra gratuita. CARDOSO (1993, p. 183), analisando a primeira geração de mutirões, afima que:

"em função dos menores custos indiretos e da não incidência de alguns desses custos e da mão-de-obra mutirante, o custo total incidente de construção para o mutirão é cerca de $45 \%$ inferior ao custo total de construção convencional (US\$ 146.00/m2 para o mutirão e US\$268.00/m2 para o convencional). Na diferença acima, 18\% corresponde a mão-de-obra e $21 \%$ a custos indiretos do sistema convencional, os quais são inexistentes ou muito inferiores para o sistema de mutirão e 5,5\% a custos indiretos subsidiados do mutirão".

Nabil Bonduki aponta para uma maior qualidade dos projetos (de arquitetura e urbanismo) em relação à média do que se produziu no país, como uma decorrência da autonomia das assessorias técnicas em sua elaboração, combinada com um momento da administração pública (gestão Erundina na PMSP) em que se deu maior importância para a etapa de projeto, nos vários programas. E atribui a qualidade das obras ao fato de sua execução ser realizada diretamente ou gerenciada pelos futuros moradores e, portanto, sob controle dos maiores interessados em garantir a qualidade (BONDUKI, 2000, p. 50).

Kyung Mi Lee, discutindo o programa de mutirões com autogestão da CDHU em parceria com a UMM, também, menciona como ponto positivo a qualidade dos projetos diferenciados apresentados pelas assessorias técnicas. Mas, por outro lado, cita como aspectos negativos os custos altos e a desmotivação de mutirantes em vários canteiros, em conseqüência dos longos prazos de análise de projeto pela CDHU, pela dificuldade da companhia de trabalhar com processos participativos (LEE, 2005, p. 40-41).

Ainda sobre a qualidade de projetos e obras, Jorge Oseki, no debate após a conferência do Prof. Francisco de Oliveira que abordaremos a seguir, disse:

"O que as empreiteiras fazem com trabalho pago, não chega aos pés do que se faz com mutirão, em qualidade. [......] Você olha e diz que não parece autoconstrução, parece "coisa holandesa"'.

A possibilidade de, a partir do trabalho no mutirão e na gestão do empreendimento, se estabelecer uma maior organização e coesão do grupo que 
morará no mesmo conjunto, também, se constitui num dos aspectos do programa apontados como positivos. Sobre isso, Ermínia Maricato diz:

"Aqui [nos mutirões] também não há a relação alienada dos conjuntos convencionais de COHAB's, depósito de pessoas como vimos. A identidade do morador com a moradia, com seu entorno, com a vizinhança é muito maior" (MARICATO, 1997, p. 61).

Caio D'Amore de Carvalho a esse respeito afirma:

"Nos empreendimentos em que há ação do Movimento, há menos problemas nos períodos de pós-ocupação [relativos a]: inadimplência, gestão do condomínio, depredação, manutenção predial" (CARVALHO, 2004, p. 171).

Em entrevista em 1994, para um caderno do Instituto Pólis sobre mutirões com autogestão, Paulo Teixeira, à época consultor da ANSUR (Associação Nacional do Solo Urbano), da qual tinha sido Coordenador Geral e que, posteriormente, na gestão Marta Suplicy, foi Secretário da Habitação e Presidente da COHAB, ponderava:

"Por último, parece-me que a experiência de construção de casas ainda não desaliena ou conscientiza as pessoas. Deveríamos buscar meios de realizar um processo educativo nesta experiência de autogestão. Isto estimula outras reflexões, como a questão da natureza do Estado, o papel do movimento popular, etc." (SILVA, 1994, p. 129).

O Prof. Francisco de Oliveira, na conferência "Papel da Autoconstrução para a Acumulação Capitalista no Brasil" ${ }^{66}$, disse:

“Tem uma liderança de Santa Maria Goretti, um mutirão em Fortaleza, que diz o seguinte: "Hitler não estava errado, é preciso coagir para manter a unidade da comunidade". Não exageremos, ela não está falando de câmaras de gás, ela está falando da ilusão do povo. É preciso que exista um ente místico chamado "povo", e este "povo" é a comunidade, para que o mutirão funcione. Cria-se aquela comunidade ilusória, que não resiste um dia, depois de concluídas as casas, para obrigar cada um a doar seu próprio trabalho: isto não é formação de cidadania, eu sinto muito, está no pólo oposto. E, ainda que seja exagerado chamar essa senhora de "adepta de Hitler", ela trabalha com o mesmo método.

\footnotetext{
${ }^{66}$ Realizada no Seminário de Pesquisa: "Políticas habitacionais, produção de moradia por mutirão e processos autogestionários: balanço crítico de experiências em São Paulo, Belo Horizonte e Fortaleza", em 2004.
} 
O método da ilusão necessária para forjar uma identidade que não é real, que não subsiste senão pelo lado das carências. Quando esta ilusão desaparece, assim que a casa foi finalmente conseguida, desaparece a coesão, desaparece a identidade com aquele projeto. São formas, portanto, que estão na linha limítrofe, às vezes aparecendo como exercício de cidadania, às vezes como forma de violência".

O projeto participativo, a possibilidade dos futuros usuários participarem da elaboração dos projetos é, freqüentemente, apontada como uma das vantagens do programa. Para Reginaldo Ronconi em entrevista a Ângela Amaral:

“O projeto participativo não pode ser visto como panacéia, [...][mas] é a maior ferramenta para a construção da cidadania. Você pode desenvolver mil dinâmicas e elas não fornecerem nenhum subsídio além daqueles que você já tinha para o projeto; não dá pra mitificar, dizer que o projeto participativo vai dar um projeto melhor, necessariamente, não é isso, aliás às vezes a gente tem que mediar muito alguns desejos que estão mal expressos pela população [....]. Ele é a ferramenta mais importante para a construção da cidadania, porque faz com que as pessoas que estão envolvidas passem a se reconhecer e a reconhecer em si outras dimensões que elas não conhecem, que sua história de vida não permitiu, e a tomar decisões numa outra escala [....]" (AMARAL, 2001, p. 215).

Caio D'Amore de Carvalho relativiza a importância do projeto participativo, quando diz:

"[.....] vale ressaltar que o caráter "pedagógico" que é atribuído ao projeto, através do qual seria possível ampliar as discussões e compreensão da cidade pelo usuário, não supera sua função na organização da produção. Os "desejos" do mutirante sobre sua casa, por sua vez, considerando-se o abismo de informações e as restrições de repertório, não consegue se sobrepor às condições e normas técnicas e aos limites do financiamento para habitação popular. A participação finda, assim, bastante restrita (ou instrumental). Tem efeito consultivo (o que não é irrelevante), e até lúdico em alguns métodos de projeto. Os depoimentos dos mutirantes nos empreendimentos estudados comprovam essa restrição, a despeito da supervalorização nos circuitos profissionais" (CARVALHO, 2004, p. 164). 
Segundo afirmações do livro "Pluralismo na Habitação", em que é feita uma comparação entre vários programas habitacionais (ou modos de provisão, de acordo com a terminologia por ele adotada) e, dentre outras coisas, relatada uma pesquisa sobre o nível de satisfação dos moradores com as unidades habitacionais em que residem, não é significativa a diferença de nível de satisfação entre os moradores que participaram do projeto arquitetônico, em programas de mutirão, daqueles que não participaram, tendo sido atendidos em programas convencionais (WERNA et al, 2001, p. 255).

A questão do sobre-trabalho que haveria no mutirão é discutida por vários autores. Em a "Crítica À Razão Dualista", o Prof. Francisco de Oliveira diz:

"Uma não-insignificante porcentagem das residências das classes trabalhadoras foi construída pelos próprios proprietários, utilizando dias de folga, fins de semana e formas de cooperação como o "mutirão". Ora, a habitação, bem resultante dessa operação, se produz por trabalho não pago, isto é, supertrabalho. Embora aparentemente esse bem não seja desapropriado pelo setor privado da produção, pois o seu resultado - a casa - reflete-se numa baixa aparente do custo de reprodução da força de trabalho - de que os gastos com habitação são um componente importante - e para deprimir os salários reais pagos pelas empresas. Assim, uma operação que é, na aparência, uma sobrevivência de práticas de "economia natural" dentro das cidades, casa-se admiravelmente bem com um processo de expansão capitalista, que tem uma de suas bases e seu dinamismo na intensa exploração da força de trabalho" (OLIVEIRA, 2003, p. 59).

O mesmo professor, na conferência já mencionada neste texto, diz:

[.......] "A industrialização brasileira foi sustentada em duas fortes vertentes. A primeira, a vertente estatal, através da qual o Estado transferia renda de certos setores, através da qual o Estado subsidiava a implantação industrial. E o segundo pé era os recursos da própria classe trabalhadora, que autoconstruía sua habitação e com isso rebaixava seu custo de reprodução."(p. 16) [.......] 0 mutirão é virtuoso porque é excepcional. Não pode ser generalizável. Para ser generalizável ele supõe que as pessoas sejam capazes de dar $20 \%$ de seu tempo de trabalho para a autoconstrução. Isto não pode ser o objetivo de uma política de habitação. Eu sinto muito, eu discordo de frente. Exatamente porque ele é excepcional ele pode ser bonito, pode ser uma boa solução arquitetônica, 
pode ser urbanisticamente interessante, mas não pode ser generalizável. [.......] Como é que o capitalismo abordou a questão da habitação? Pelo aumento da produtividade do trabalho, gente, esta é a chave. Nem o mutirão nem a autoconstrução fez isso. Não pode fazer, é intrinsecamente e conceitualmente impossível. O processo do capital é outro, é o aumento da produtividade do trabalho, vale dizer, aumento da taxa de exploração. É assim que resolveu, quando resolveu, o problema da habitação."

No debate que aconteceu nessa mesma conferência, Jorge Oseki reconhece o sobre-trabalho, mas levanta a questão de que os mutirões seriam "nichos de contra-poder":

"Então não é que o mutirão "não é sobretrabalho", não é isso [......] É que de repente surge o que Lefebvre chama, afinal de contas, de nichos de contrapoder, que são interessantes de serem vistos".

Segundo Sachs:

"Gabriel Bolaffi (1986, F) retoma o argumento de Francisco de Oliveira, segundo o qual o recurso ao mutirão constitui uma prova do caráter selvagem e retrógrado do capitalismo brasileiro na medida em que cria uma forma mistificada de participação" (SACHS, 1999, p. 83).

Para a mesma autora, "Do lado oposto, para Carlos Nelson Coutinho (1980, F), embora a autoconstrução possa representar um trabalho não-remunerado, seu produto (a habitação) tem um valor de troca, assim como um valor de uso". E mencionando a grande freqüência de transações envolvendo moradias autoconstruidas e precárias na periferia, conforme pesquisa de Bonduki e Rolnik feita em Osasco, acrescenta que: "numa sociedade capitalista como a brasileira, a posse de um bem, mesmo num loteamento irregular, confere ao proprietário certa respeitabilidade. É o primeiro passo para uma estabilização e um status social" (SACHS, 1999, p. 83).

A importância dos programas de mutirão com autogestão na apropriação pelas associações e assessorias dos conhecimentos relacionados à produção de moradia que antes só construtoras, incorporadoras e escritórios de projeto possuíam. Os professores Khaled Ghoubar (FAUUSP) e Ricardo Moretti (FAUPUCCAMP) apontam para o quanto é raro o tipo de conhecimento, experiência que as assessorias possuem ao serem responsáveis, ao mesmo tempo, pelos 
projetos, orçamento, acompanhamento da aquisição dos materiais, controle dos consumos no canteiro das obras, execução das obras.

A implantação do programa foi feita com uma boa dose de dificuldade e em meio a desconfianças:

"Apesar das hesitações e preocupações de muitos, dentro e fora do governo, em repassar recursos na mão das comunidades, concretizou-se um avanço no sentido de se partilhar o poder de gestão, de decidir a demanda, de definir o projeto e escolher o material". (AMARAL, 2001, p. 193)

Sobre os obstáculos para se introduzir um programa novo, sobre a dificuldade do Estado de partilhar poder no caso dos mutirões com autogestão, Reginaldo Ronconi cita a "resistência" de parcela dos assistentes sociais de HABI (AMARAL, 2001, p. 218), aponta para pouca contribuição de funcionários do Estado para a formatação de programas inovadores. Fala também que significativas mudanças qualitativas ocorreram e se difundiram pelo país, a partir da implantação de novos programas ou de novas posturas no interior do Estado: a aceitação da participação popular como parte do processo (vale lembrar de experiências anteriores, como a da CDHU nos tempos do $\mathrm{PMH}$ ), da autogestão, do papel das assessorias técnicas. Sendo que, em outros lugares, como Cuba e Barcelona, causou estranheza a experiência brasileira de participação popular, e perguntavam se não era muito difícil desenvolver projeto ouvindo tantos palpites (AMARAL, 2001, p. 219).

Sobre os mutirões com autogestão, Helena Menna Barreto Silva diz:

"Embora a grande maioria dos movimentos por moradia defenda o mutirão e apresente provas irrefutáveis da melhor qualidade da moradia assim obtida, permanecem as discussões sobre as vantagens e limites desse tipo de programa, havendo nos extremos críticos radicais dessa forma de "sobretrabalho" e os que defendem como a principal solução de moradia popular a ser implantada nos programas atuais. Para muitos, o essencial seria a autogestão do empreendimento, independente do percentual de mão-de-obra gratuita incorporada na construção. No meio termo, o mutirão pode ser considerado como uma das modalidades de produção com recursos públicos, mas que deve ainda ter sua produtividade bastante melhorada. Além disso, não 
parece sensato imaginar soluções em grande escala com base no mutirão" (SILVA, 1997, p. 138).

Ermínia Maricato coloca que:

"A defesa apaixonada do mutirão com autogestão só encontra contraponto nos ataques persistentes e suspeitos daqueles que Ihe fazem oposição sistemática. Nesse quadro polarizado, a avaliação dos resultados do programa nem sempre é fácil e o maniqueísmo - contra e a favor - se impõe. A simples e evidente constatação de que a autoconstrução, prática largamente difundida do morador construir sua própria casa, constitui uma forma de barateamento da força de trabalho no Brasil foi muitas vezes identificada como forma de argumentação dos que são contrários ao mutirão (BONDUKI, 1993). Já que entre os que Ihe fazem oposição sistemática estão os conservadores que desqualificam a participação popular como competente para gerir recursos públicos" (MARICATO, 1997, p. $59)$.

Já a arquiteta e gerente da CDHU, Valentina Denizo, levanta a questão sobre para quem fica a economia obtida com o mutirão:

“[.....]O mutirão se tornou a única forma de acesso à moradia sem o sorteio, que é a forma adotada hoje pela $C D H U$, e o que eu percebia é que a forma de acesso ao mutirão é um conjunto de processos de clientelismo e cooptação. $A$ gente não percebia, em alguns casos, essa tão falada organização social. Na prática, o que a gente via era uma guerra para ver quem chegava primeiro a esta alternativa de acesso à moradia. Outra questão: o mutirão serve a quem? Como moradia, apesar de ser muito barata, ela ainda é bastante inacessível a esta população que está nos estratos mais baixos de renda. Como se tem uma política de cobrar 20\% a 30\% do salário por 20 anos, quem faz mutirão e quem não faz mutirão acaba pagando a mesma coisa. Eu percebia, talvez com ingenuidade e devido à minha ignorância em questões econômicas, que quem está internalizando este benefício, na verdade, é o poder público e não a população."

Essas questões, essas controvérsias todas estavam latentes no começo da gestão Marta Suplicy. Porém, não se aprofundou muito o debate em torno delas. Tanto porque eram mais prementes as ações que permitissem a retomada ou a aceleração das obras paralisadas ou que avançaram muito lentamente nas administrações Maluf e Pitta; o início das obras que eram objeto de 11 convênios 
assinados no governo de Celso Pitta; e a sinalização, para os movimentos de moradia, que haviam colocado suas reivindicações, desde o começo da gestão de Marta Suplicy, do propósito dessa gestão de firmar novos convênios e iniciar novas obras. Quanto porque era muito forte, muito apaixonada a defesa dos mutirões, que inibia críticas e sugestões de ajustes no programa e fez com que, de certa forma, predominasse uma tendência favorável à não ampliação de mecanismos de controle pelo poder público, justificada pela idéia de garantir uma maior autonomia às associações, de não aumentar a burocracia e de agilizar o andamento dos empreendimentos. Posteriormente, uma série de ajustes foram discutidos e introduzidos, entre as regras do programa, como abordaremos adiante.

A componente de premência por resultados, que contribuiu para conter discussões em torno das questões apontadas acima, guarda uma semelhança com o que aconteceu na gestão Erundina. Sobre isso, Nabil Bonduki diz:

"A polêmica sobre estes aspectos poderia ter provocado enormes atrasos na implementação do programa, sobretudo considerando-se a lentidão normal da tomada de decisões pelo poder público no país (a que não escapou - muito pelo contrário - a administração do PT em São Paulo), principalmente se se formassem grupos de pressão em torno da aceitação ou da rejeição. No entanto, a certeza que se tinha de que, depois de quase dez anos de experiências, era fundamental demonstrar a viabilidade da autogestão como uma alternativa séria para enfrentar o problema da moradia, assim como a pressão do movimento por acelerar seu atendimento, impulsionaram uma rápida formulação e implementação desse programa" (BONDUKI, 2000, p. 43).

$\mathrm{Na}$ gestão Erundina, haviam sido assinados 90 convênios com associações para a construção de 11.935 uh's, em canteiros espalhados por toda a cidade, que incluíam 2.219 uh's verticalizadas, e, segundo se estimava, envolviam 12.000 mutirantes e 1.000 novas lideranças formadas nesse processo (AMARAL, 2001, p. 154).

Na gestão seguinte, de Paulo Maluf, ocorreu uma interrupção do repasse dos recursos para as associações, que, evidentemente, implicou na paralisação das obras, sob a justificativa de ser necessária uma auditoria da aplicação dos recursos repassados. A motivação dessa medida não parece ter sido de ordem técnica ou administrativa, mas, principalmente, de disputa político-partidária. Prestações de 
contas que, na gestão anterior, já haviam sido apresentadas pelas associações à Prefeitura foram, novamente, exigidas, mas com um nível de detalhe desnecessariamente maior e foram, longamente, analisadas pela SEHAB e pelo Tribunal de Contas do Município - TCM (BONDUKI, 2000, p.124). A forma como a gestão Maluf atuou em relação aos programas da gestão Erundina é descrita de forma minuciosa por Ermínia Maricato (MARICATO, 1999, p. 79).

Não foram constatadas irregularidades, como apontado por vários autores $^{67}$. No entanto, por um grande período as obras ficaram paralisadas, sofrendo deterioração e algumas, como é o caso do Jardim Celeste, sendo parcialmente tomadas por ocupações irregulares, configurando favelas nos interstícios vazios dos conjuntos habitacionais.

No começo de 2001, do conjunto de convênios assinados na gestão Erundina e que passou a ser denominado de $1^{\text {a }}$ Geração, 6.795 uh's necessitavam ainda da realização de serviços, tais como a complementação da infra-estrutura ou das edificações; e 722 uh's deveriam ser iniciadas, pois faziam parte de etapas ( $2^{\mathrm{a}}$ ou $3^{a}$ ) previstas nos convênios originais. Em alguns dos convênios, havia saldos de valores, cujo repasse permitiu que as obras fossem concluídas, sem acréscimos, apenas com os reajustes estipulados.

Para os mutirões de $1^{\text {a }}$ Geração cujas obras haviam sido iniciadas entre 89 e 92, a retomada dos serviços ocorreu em meados de 2001. Nos casos em que a infra-estrutura havia se deteriorado com a paralisação das obras, houve necessidade de revisão ou mesmo elaboração de novos projetos, e a contratação de empreiteiras para a execução dos serviços.

$\mathrm{Na}$ administração Pitta, haviam sido assinados 22 convênios com associações para a construção de novos conjuntos habitacionais em regime de mutirão com autogestão, mas, no entanto, não havia sido dado nenhum outro passo no sentido do início efetivo das obras. A intenção na gestão Marta Suplicy era dar prosseguimento a esses convênios, mas as restrições orçamentárias não permitiriam o início simultâneo de todas as obras. Portanto, foi proposto às associações atendimento através do PAR (Programa de Arrendamento Residencial da CEF em

$\overline{67}$ AMARAL, 2001; BONDUKI, 2000, p. 123-124; MARICATO, 1997, p. 61 e 86; WERNA et al, 2001, p. 
parceria com a SEHAB/COHAB), um programa com características muito diferentes, no qual, evidentemente, não haveria autogestão, seria muito pequena a possibilidade das associações interferirem no projeto e a composição da demanda deveria atender aos critérios da CEF, muito mais rigorosos do que os do $\mathrm{FMH}$ quanto à comprovação de capacidade de pagamento.

Metade das associações aderiu ao PAR e a outra metade preferiu permanecer no Programa de Mutirões, compondo um grupo que foi denominado $2^{a}$ Geração.

Foram iniciados em momentos muito próximos os trabalhos relativos aos 11 convênios da $2^{\mathrm{a}}$ Geração ${ }^{68}$ (1.915 uh's) e aos 11 convênios da $1^{\mathrm{a}}$. Geração ${ }^{69}$. (722 uh's) mas que previam o início de novas etapas de obras. O que totalizava 2.637 uh's sendo iniciadas em meados de 2001.

A elaboração dos primeiros projetos da $2^{a}$ Geração começou no final de 2001. Dos seus 11 empreendimentos, excetuando o City Jaraguá, todos os outros utilizaram a verticalização. Foi sugerida às associações a adoção de tipologias verticalizadas já desenvolvidas pela COHAB-SP, mas apenas a associação Bela Vitória (Minas Gás) aceitou a sugestão e todas as outras optaram pela elaboração de projetos específicos (VIEIRA, Núria, 2005).

As reivindicações dos movimentos por moradia pela ampliação do programa continuaram e influenciaram a montagem de uma $3^{a}$. Geração de mutirões, que envolve 4.312 uh's. A definição das associações que compuseram essa $3^{a}$. Geração foi feita por meio de um processo de credenciamento e seleção, muito semelhante a uma licitação pública. Para isso, a COHAB publicou um edital com indicação das terras que destinaria ao programa e regiões onde, não dispondo de terras, buscaria desapropriá-las. Na data prevista pelo edital, as associações

190.

68 2a. Geração: I. Monteiro/Paulo Freire, I. Monteiro/Unidos Venceremos, Irmã Lucinda, Jd. Bela Vista. Jd. Celeste V/Imaculada Conceição, Jd. Educandário/Recanto da Felicidade, Jd. Marabá/Ernesto Che Guevara, Minas Gás/Bela Vitória, Pq. Europa I, Resid. City Jaraguá, Sítio Conceição/St. Luzia.

$691^{\text {a }}$. Geração com novas etapas: Autódromo II, Barro Branco/Vida Nova (3a etapa), Barro Branco I, II, III e IV ( $3^{a}$ etapa), Lapena ( $2^{a}$ etapa), Miguel Ackel/Clube de Mães (2a etapa), Miguel Ackel/Vila Simone ( $2^{\mathrm{a}}$ etapa), Valo Velho I/União de Todos ( $2^{\mathrm{a}}$ etapa), Valo Velho I/Unidos Venceremos ( $2^{\mathrm{a}}$ etapa). 
deveriam apresentar envelopes que conteriam: a opção pelos terrenos ou regiões, e os documentos para a habilitação e para a classificação. Os documentos para a habilitação deveriam ser obrigatoriamente apresentados por todas as associações, sob pena de eliminação. E os documentos para classificação seriam utilizados para atribuir uma pontuação a cada associação, necessária caso houvesse mais de uma associação interessada em determinado terreno.

O critério de julgamento estabelecia que seriam considerados, na pontuação, aspectos relativos $\mathrm{a}^{70}$ :

1. Experiência da associação e de seus membros, verificados através do tempo acumulado por membros da diretoria em construções em regime de mutirão com autogestão, o tempo de existência da entidade e o número de unidades construídas sob esse regime, através de convênios firmados com órgãos públicos.

2. Funcionamento interno das associações. Isso se traduzia numa maior valorização e, portanto, maior pontuação àquelas que dispusessem de uma maior número de instrumentos que visassem um funcionamento mais democrático. Dentre esses instrumentos constavam, por exemplo, "existência de critérios para a indicação de associados que participarão do processo de mutirão, definidos em instrumentos públicos", "tempo de mandato da diretoria" (atribuiu-se mais pontos às associações em que o tempo fosse menor) e "existência de instrumentos de comunicação interna e/ou externa".

3. Proximidade dos terrenos pelos quais a associação optasse aos locais de residência das famílias que compunham sua demanda. Buscando, ao valorizar a maior proximidade, reduzir os deslocamentos durante a obra e os transtornos para a ocupação após sua conclusão (matrículas em escolas, aumento da distância a locais de trabalho e de residência de familiares e amigos, etc.).

4. Experiência no desenvolvimento de projetos sociais, tais como de formação educacional, geração de renda, cooperativismo, formação de multiplicadores capacitados para a autogestão, etc.

70 VIEIRA, Núria, 2005, p. 19; e COHAB-SP, Edital, 04/10/02. 
5. Compromisso de oferecer poupança prévia, que se entendia como uma forma de estimular um comprometimento das famílias com o retorno do financiamento e de se dispor, no curto prazo, de uma nova receita, se bem que de valor não muito significativo.

Esse processo de credenciamento e seleção de sociedades civis foi uma das mais importantes mudanças introduzidas no Programa, durante a gestão 20012004. Com ele, buscava-se garantir a isonomia e a transparência no processo de definição das associações que seriam atendidas pelo Programa de Mutirões com Autogestão. E, juntamente com uma revisão das normas do Programa (a ser abordada adiante), buscava-se melhorar o arcabouço legal de forma a contribuir para sua continuidade, independentemente da simpatia que por ele tivessem as futuras administrações municipais.

No entanto, há quem não atribua a mesma importância a esse processo de credenciamento, como Caio de Carvalho. Por entender, entre outras coisas, que seria "mera formalidade burocrática", pois, como afirma, teriam ocorrido negociações entre movimentos que levaram à divisão de "demandas de um mesmo empreendimento entre dois Movimentos"; e que esse processo representaria "uma seleção de demanda por habitação, que, de acordo com a Constituição Federal é um direito universal". (CARVALHO, 2004, p. 56).

Mesmo considerando a possibilidade de acertos entre movimentos e associações, é um avanço que haja um processo como esse; com regras explicitamente definidas e que garantem, para os vários grupos interessados, maior clareza sobre as condições de entrada no programa. Quanto à "contradição" em relação ao que dispõe a Constituição Federal, ela permanecerá enquanto não houver recursos para que toda demanda seja atendida de uma só vez, tornando necessário o estabelecimento de critérios para a escolha de quem será atendido primeiro. Aliás, mesmo que, hipoteticamente, houvesse recursos para atendimento de toda a demanda no mesmo momento, seria necessário um critério, no mínimo, para a escolha de quem seria ser atendido nesse ou naquele terreno. Dessa forma, é melhor que haja critérios claros e que sejam públicos.

As mudanças nas regras do Programa foram promovidas pela a Resolução CMH No 08, de 29/03/04, que revogou e substituiu as normas anteriores 
do programa. Conforme relatado por Núria Vieira, uma ativa participante do processo de formulação do conjunto de novas regras que abordamos aqui, elas resultaram: primeiro, de discussões de um "grupo de trabalho formado por assessorias técnicas, associações conveniadas e técnicos de SEHAB/COHAB", que manteve reuniões periódicas por oito meses e submeteu uma primeira proposta a uma comissão de conselheiros do $\mathrm{CMH}$. Essa comissão, integrada por representantes de assessorias técnicas, associações e, também, de entidades patronais da construção civil, elaborou uma segunda proposta, que, por sua vez, foi apresentada, discutida em três plenárias do $\mathrm{CMH}$ e, por fim, aprovada, concluindo um processo de negociação, que, segundo essa autora, foi "amplo e democrático" (VIEIRA, Núria, 2005, p. 21).

Com a edição da Resolução $\mathrm{CMH} \mathrm{N}{ }^{\circ}$ 08, foram introduzidas modificações em diferentes aspectos do programa, sendo que aquelas relativas aos valores das porcentagens dos itens abrangidos pelo financiamento para mutirão e do teto estabelecido por unidade habitacional, além de estarem listadas a seguir, estão sintetizadas na tabela onde são indicadas as alterações desses valores ao longo do tempo e também os valores adotados pelo programa de mutirões com autogestão da CDHU. As principais modificações no programa, efetuadas em 2004, estão relacionadas a seguir:

1. Retirada da vedação ao atendimento, pelo programa, de pessoas que tivessem "invadido" imóvel vinculado a intervenções com recursos do $\mathrm{FMH}$.

2. Mudança da peridiocidade das medições de mensal para bimestral (d.1 - Das Obrigações das Assessorias Técnicas).

3. Alteração dos valores limites do financiamento por uh, que haviam ficado muito baixos quando fixados pela Instrução Normativa-SEHAB-G No 01/00. Mas, em relação ao valor máximo vigente em agosto de 1992 (reajustado pela UPF e pelo ICC), o novo teto foi elevado em $8,7 \%$ e rebaixado em 1,8\% e 4,7\%, respectivamente, para as obras pequenas, médias e grandes. Em relação ao valor máximo vigente a partir de setembro de 97 , para edificações verticais, o novo teto foi aumentado 
em $13,5 \%$ e $2,5 \%$ e diminuído em $0,41 \%$, respectivamente, para as obras pequenas, médias e grandes.

4. Introdução de porcentagens para remunerar as assessorias social e contábil, mas também com uma redução da porcentagem destinada à assessoria técnica. Dessa forma, o total destinado às assessorias teve uma pequena diminução para as obras maiores (de 7 para $6,36 \%$ ) e um considerável aumento para as obras menores (de 7 para 9,99\%). Um aumento mais significativo já havia sido efetuado, quando se passou dos $4 \%$ destinados a assessoria técnica, que haviam vigido na gestão Erundina, para os 7\%, que passaram a valer a partir de 1997. Esse valor de $7 \%$ é igual ao adotado pela CDHU.

5. Introdução de uma porcentagem para projeto social, reduzindo os valores para projeto técnico. No total, os valores destinados a projeto foram mantidos para as obras menores (em 5\%), e reduzidos para as obras maiores (de $3 \%$ para 1,78\%). Para efeito de uma parametrização, pode-se observar que o valor adotado pela CDHU é de $1,50 \%$.

6. Pequena modificação da porcentagem para mão-de-obra especializada, que ficou próxima dos 30\%, que já haviam sido estabelecidos na Instrução Normativa-SEHAB-G N $N^{0}$ 01/00 (gestão Pitta). Esse aumento para $30 \%$ foi muito expressivo em relação ao que vigorava na gestão Erundina (10\%) e ao que é adotado por programa semelhante da CDHU (11\%).

A elevação para $30 \%$ dos recursos para mão de obra especializada alterou características importantes do programa, permitindo que crescesse a participação da mão-de-obra terceirizada e que fosse reduzida a da mão-de-obra mutirante, fazendo com que se aproximasse da proposta (ao que parece, da maioria das associações e assessorias, mas não unânime) de que haja mais autogestão e menos mutirão.

É interessante notar que composições de custo da CDHU, para a construção de edifícios habitacionais (verticais) por empreitada, indicam que a mãode-obra representa por volta de $46 \%$ do total dos custos diretos e que os materiais e 
os outros custos diretos representam $54 \%$. Tomando os valores das medições finais das obras também por empreitada dos conjuntos habitacionais Parque do Gato e Olarias, construídos pela $\mathrm{COHAB/FMH}$, verifica-se que, no primeiro, a mão-de-obra e os equipamentos foram responsáveis por $34,69 \%$ dos custos e, no segundo, por $41,27 \%$. Dessa forma, uma comparação, grosso modo, dos valores despendidos com mão-de-obra e serviços especializados nas obras por mutirão e em tais obras por empreitada da CDHU e da COHAB-SP, confirma que os convênios estão permitindo que a participação da mão-de-obra mutirante.seja superada pela da mãode-obra contratada.

Ao contrário do que seria de se esperar, não houve uma reação forte contra tal alteração por parte das entidades empresariais, sendo que duas das mais representativas, o SINDUSCON-SP e a APEOP ${ }^{71}$, têm assento no Conselho Municipal de Habitação e, em manifestações pela imprensa, há muito tempo, questionam a importância dos programas de mutirões como uma alternativa de política habitacional. Num artigo sobre esse programa, que talvez represente bem o pensamento das entidades empresariais, João Cláudio Robusti ${ }^{72}$ (ROBUSTI, Construfax $\left.n^{\circ} 624,23 / 07 / 99\right)$ aponta para:

- "Deseconomias", pois se pagaria, "direta ou indiretamente, pelo trabalho de engenheiros, mestres, pedreiros, pintores, eletricistas, encanadores" e haveria desperdício na "manipulação inadequada de materiais" e no retrabalho.

- A incerteza sobre o recolhimento de encargos sociais e tributos relativos aos trabalhos no mutirão.

- A ausência de responsabilidade formal pelas obras.

- A não aplicação de "critérios concorrenciais para a escolha de quem deve receber recursos públicos, para fazer o quê, sob quais condições de tempo, preço e qualidade", o que, segundo ele, "afrontaria" a Lei de Licitações (8666).

\footnotetext{
71 Sindicato da Indústria da Construção Civil do Estado de São Paulo e Associação Paulista de Empresários de Obras Públicas.

72 Robusti foi conselheiro do $\mathrm{CMH}$, no período abordado, e, atualmente, é presidente do SINDUSCON, do qual foi vice-presidente para habitação, quando da publicação do artigo.
} 
A questão das tais "deseconomias" é controversa, mas é importante lembrar do que foi dito anteriormente sobre custos no programa de mutirões com autogestão, especialmente, do trabalho de CARDOSO (1993, p. 183) e observar que, efetivamente, as obras por mutirão tem atingido custo inferior ao das empreitadas e por qualidade e área construída, freqüentemente, superiores. Quanto ao recolhimento de encargos sociais e tributos, eles não incidem sobre o trabalho dos mutirantes, mas incidem sobre qualquer prestação de serviços, tanto técnicos, como especializados e não especializados, contratados para a execução das obras.

Em relação à ausência de licitação, se pelo lado da seleção das associações, pode-se dizer que ela deixou de ocorrer, com o processo de credenciamento; pelo lado da escolha pelas associações, dos fornecedores de mãode-obra especializada, equipamentos e materiais, ela persiste, não se adotando procedimentos com o rigor exigido pela Lei Federal 8.666/93, que regulamenta as licitações e contratações pela administração pública. $E$ isso pode se constituir num flanco pelo qual o programa passe a ser questionado pelos órgãos de controle, num momento em que os tribunais de contas, principalmente o da União (TCU), estão exigindo que entidades privadas que recebem recursos públicos (fundações universitárias, etc.) realizem procedimentos, se não iguais, pelo menos semelhantes às licitações. Se isso passar a ser exigido nas compras e contratações feitas pelas associações nos programas de mutirão com autogestão, estará sendo considerado, principalmente, o aspecto da isonomia para os vários fornecedores, na disputa por parcelas de recursos originários de fundos públicos, mas implicará num aumento da burocracia a ser atendida pelas associações, assessorias e órgãos públicos que fiscalizam a execução dos convênios.

O questionamento que já ocorre sobre a adequação à Lei 8.666/93 é uma das questões centrais a serem enfrentadas pelo programa. É muito importante que se proponha uma forma de equacionamento que evite que seja travado por questionamentos dessa espécie. Talvez haja necessidade, inclusive, de lei federal que trate da questão. Vale lembrar que a Lei que criou o PAR, isenta esse programa de seguir as determinações da Lei 8.666/93. 
TAB. - Porcentagens destinadas aos vários itens abrangidos pelos convênios e valores máximos das uh's

\begin{tabular}{|c|c|c|c|c|c|c|c|c|c|c|}
\hline \multirow{2}{*}{\multicolumn{2}{|c|}{ Itens abrangidos pelos convênios }} & \multirow{2}{*}{$\begin{array}{c}\text { CDHU/ } \\
\text { Programa } \\
\text { Paulista de } \\
\text { Mutirões - } 96\end{array}$} & \multirow{2}{*}{$\begin{array}{c}\text { HABI/ FUNAPS } \\
\text { Comunitário - } \\
1990\end{array}$} & \multicolumn{2}{|c|}{$\begin{array}{c}\text { COHAB/FMH, a partir de } \\
17 / 09 / 97\end{array}$} & \multicolumn{2}{|c|}{$\begin{array}{l}\text { COHAB/FMH, entre } \\
17 / 06 / 00 \text { e } 28 / 03 / 04\end{array}$} & \multicolumn{3}{|c|}{$\mathrm{COHAB/FMH,} \mathrm{a} \mathrm{partir} \mathrm{de} \mathrm{29/03/04}$} \\
\hline & & & & \begin{tabular}{r|} 
habitações \\
horizontaliz.
\end{tabular} & $\begin{array}{l}\text { habitações } \\
\text { verticaliz. }\end{array}$ & até 50 uh's & $\begin{array}{c}\text { mais de } 151 \\
\text { uh's }\end{array}$ & $\begin{array}{c}\text { abaixo de } 60 \\
\text { uh's }\end{array}$ & $\begin{array}{l}\text { entre } 171 \text { e } \\
180 \text { uh's }\end{array}$ & $\begin{array}{c}\text { acima de } 291 \\
\text { uh's }\end{array}$ \\
\hline \multirow{7}{*}{ 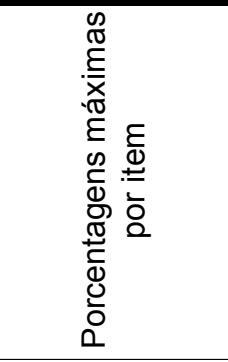 } & $\begin{array}{l}\text { Mão-de-obra } \\
\text { especializada e } \\
\text { controle tecnológico }\end{array}$ & $11,00 \%$ & $10,00 \%$ & $10,00 \%$ & $13,85 \%$ & $30,00 \%$ & $30,00 \%$ & $28,60 \%$ & $31,65 \%$ & $32,59 \%$ \\
\hline & Canteiro & $2,50 \%$ & $4,00 \%$ & $3,20 \%$ & $3,20 \%$ & $7,00 \%$ & $4,00 \%$ & $7,48 \%$ & $4,12 \%$ & $3,56 \%$ \\
\hline & Assessoria contábil & & \multirow{4}{*}{$4,00 \%$} & & & & & $1,03 \%$ & $0,38 \%$ & $0,23 \%$ \\
\hline & Assessoria técnica & $5,50 \%$ & & $7,00 \%$ & $7,00 \%$ & $7,00 \%$ & $7,00 \%$ & $6,66 \%$ & $6,17 \%$ & $5,43 \%$ \\
\hline & Assessoria social & & & & & & & $2,30 \%$ & $1,13 \%$ & $0,70 \%$ \\
\hline & Projeto técnico & $1,50 \%$ & & $2,30 \%$ & $2,30 \%$ & $5,00 \%$ & $3,00 \%$ & $4,60 \%$ & $2,22 \%$ & $1,64 \%$ \\
\hline & Projeto social & $0,00 \%$ & & & & & & $0,44 \%$ & $0,23 \%$ & $0,14 \%$ \\
\hline \multicolumn{2}{|c|}{ Materiais } & $79,50 \%$ & $82,00 \%$ & $77,50 \%$ & $73,65 \%$ & $51,00 \%$ & $56,00 \%$ & $48,89 \%$ & $54,10 \%$ & $55,71 \%$ \\
\hline \multicolumn{2}{|c|}{ Total } & $100,00 \%$ & $100,00 \%$ & $100,00 \%$ & $100,00 \%$ & $100,00 \%$ & $100,00 \%$ & $100,00 \%$ & $100,00 \%$ & $100,00 \%$ \\
\hline \multirow{2}{*}{$\begin{array}{l}\text { Teto do financ. } \\
\text { por uh, em } \\
\text { valores } \\
\text { históricos }\end{array}$} & uh's horizontais & & $1.114,80$ UPF & $\mathrm{R} \$ 12.2$ & 00,00 & $\mathrm{R} \$ 12.2$ & 00,00 & \multirow{2}{*}{$\mathrm{R} \$ 25.381,01$} & \multirow{2}{*}{$\mathrm{R} \$ 22.934,77$} & \multirow{2}{*}{$\mathrm{R} \$ 22.270,67$} \\
\hline & uh's verticais & & & $\mathrm{R} \$ 13.2$ & 00,00 & $\mathrm{R} \$ 13.2$ & 00,00 & & & \\
\hline \multicolumn{2}{|c|}{ Fonte } & $\begin{array}{c}\text { LEE, } 2005, \mathrm{p} . \\
39\end{array}$ & \begin{tabular}{|c|} 
PMSP/SEHAB/ \\
HABI, 1992, Bal. \\
Atuação
\end{tabular} & \multicolumn{2}{|c|}{$\begin{array}{l}\text { CFMH No } 04,17 / 09 / 97 \text {, } \\
\text { apud } \mathrm{CORCH}, 2001, \text { p. } 90\end{array}$} & $\begin{array}{l}\text { Instrução N } \\
\text { SEHAB-G }\end{array}$ & $\begin{array}{l}\text { ormativa - } \\
\mathrm{N}^{\mathrm{o} .} 01 / 00\end{array}$ & \multicolumn{3}{|c|}{ Resolução CMH Nº 08, de 29/03/04 } \\
\hline \multirow{2}{*}{$\begin{array}{l}\text { Teto do financ. } \\
\text { por uh, em } \\
\text { valores de } \\
\text { março de } 2004\end{array}$} & uh's horizontais & & $\mathrm{R} \$ 23.358,38$ & \multicolumn{2}{|c|}{$\mathrm{R} \$ 20.669,88$} & \multicolumn{2}{|c|}{$\mathrm{R} \$ 17.455,33$} & \multirow{2}{*}{$\mathrm{R} \$ 25.381,01$} & \multirow{2}{*}{$\mathrm{R} \$ 22.934,77$} & \multirow{2}{*}{$\mathrm{R} \$ 22.270,67$} \\
\hline & uh's verticais & & & \multicolumn{2}{|c|}{$\mathrm{R} \$ 22.364,13$} & \multicolumn{2}{|c|}{$\mathrm{R} \$ 18.886,10$} & & & \\
\hline \multicolumn{2}{|c|}{ ano e mês } & & ago/94 & \multicolumn{2}{|c|}{ nov/97 } & \multicolumn{2}{|c|}{ jun/00 } & \multicolumn{3}{|c|}{$\mathrm{mar} / 04$} \\
\hline \multicolumn{2}{|c|}{ UPF } & & $7,52(\mathrm{jul} / 94)$ & \multirow{2}{*}{\multicolumn{2}{|c|}{164,456}} & & & & & \\
\hline ICC-F & SV-Edif.(54) & & 100,000 & & & \multicolumn{2}{|c|}{194,742} & \multicolumn{3}{|c|}{278,630} \\
\hline ICC-F & V-Mat.(55) & & 100,000 & 135 & 667 & 167, & 016 & & 247,119 & \\
\hline ICC-F & SV-MO(56) & & 100,000 & 200 & 425 & 227, & 264 & & 314,506 & \\
\hline
\end{tabular}

Obs.: 1- Não foram obtidos os valores máximos estabelecidos para o Programa da CDHU

2- Os valores do ICC e UPF foram obtidos nos sites: http://www.cbicdados.com.br e http://www.abecip.org.br/sitenovo/arquivos/Upf1.xls

3- Para os reajunstes foi aplicada a variação do ICC-FGV para Edif.(54), considerando que a Resolução CMH N ${ }^{\circ}$. 08 adotou o mesmo índice p/ reajuste dos convênios de mutirão, apenas fazendo incidir o da coluna 55 sobre materiais e o da coluna 56 sobre a mão-de-obra. 
Nos quadros a seguir, são indicados os empreendimentos do Programa de Mutirões com Autogestão, o número de unidades concluídas e viabilizadas, e, no caso dos de $2^{a}$. Geração e de $1^{\text {a }}$. Geração iniciados em 2001/2002, também o avanço financeiro ao final de 2004.

Tabela 5.6

\begin{tabular}{|c|c|c|}
\hline \multirow{2}{*}{$\begin{array}{l}\text { Empreendimentos do Programa de } \\
\text { Mutirões com Autogestão }-1^{\text {a. }} \text { Geração }\end{array}$} & \multicolumn{2}{|c|}{ uh's } \\
\hline & concluídas & viabilizadas \\
\hline Alto do Riviera & 27 & 27 \\
\hline Apuanã & 802 & 802 \\
\hline Autódromo ( I ) & 60 & 60 \\
\hline Baltazar - Pq. das Andorinhas & 115 & 115 \\
\hline Baltazar Cisneros & 200 & 200 \\
\hline Barro branco I, II, III, IV e Vida Nova (1as. etapa & 250 & 250 \\
\hline Barro branco I, II, III, IV e Vida Nova (2as. etapa & 455 & 455 \\
\hline Boa Esperança / Carrãozinho & 106 & 106 \\
\hline Boa Esperança/Texima & 200 & 200 \\
\hline Celso Garcia (Casarão) & 182 & 182 \\
\hline Haia do Carrão & 45 & 45 \\
\hline Jardim Brasília / Pôr do Sol & 160 & 160 \\
\hline Jd. Celeste I & 200 & 200 \\
\hline Jd. Celeste II ( $2^{\mathrm{a}}$ etapa) & 200 & 200 \\
\hline Lapena ( $1^{\text {a. }}$ etapa) & 48 & 48 \\
\hline Lírios do Itaim & 208 & 208 \\
\hline Miguel Ackel - CONSABS II & 200 & 200 \\
\hline Miguel Ackel - V. Simone & 180 & 180 \\
\hline Monet & 225 & 225 \\
\hline Movimento Unido & 164 & 164 \\
\hline N. Sra. da Penha - $2^{a}$ etapa & & 138 \\
\hline Parque Continental - Estrela Guia & 100 & 100 \\
\hline Pedra Bonita & 172 & 172 \\
\hline Portal São Marcos & 104 & 104 \\
\hline Rio das Pedras I & 148 & 148 \\
\hline Rio das Pedras II & 148 & 148 \\
\hline São Francisco - 8 - XV novembro & 153 & 153 \\
\hline São Francisco - Sudeste & 152 & 152 \\
\hline Sítio Casablanca (Petrilli) & 200 & 200 \\
\hline Sítio Casablanca (Terra de Deus) & 154 & 154 \\
\hline Sônia Ingá & 210 & 210 \\
\hline Talara & 408 & 408 \\
\hline Valo Velho I - Povo em Ação & 212 & 212 \\
\hline Valo Velho I - União de Todos - (1ª etapa) & 20 & 20 \\
\hline Valo Velho I - Unidos Venceremos - ( $1^{\text {a }}$ etapa) & 20 & 20 \\
\hline Vila Mara I & 144 & 144 \\
\hline Vila Mara II & 144 & 144 \\
\hline Vista Alegre & 20 & 20 \\
\hline Vista Linda & 121 & 121 \\
\hline Total & 6.657 & 6.795 \\
\hline
\end{tabular}

Fonte: COHAB-SP, Relatório de Gestão 2001-2004, 2004, p. 6 
Os dados de avanço financeiro dos empreendimentos da $1^{\mathrm{a}}$. Geração iniciados entre 89 e $92^{73}$ e da $3^{a}$. Geração não constam dos quadros, porque, no primeiro caso, não teria sentido alguma análise relativa ao ritmo das obras, dada a paralisação total ou parcial durante as gestões Maluf e Pitta.

Tabela 5.7

\begin{tabular}{|c|c|c|c|c|c|}
\hline \multirow{2}{*}{$\begin{array}{l}\text { Empreendimentos do Programa de } \\
\text { Mutirões com Autogestão - } 1^{\text {a. }} \text { Geração } \\
\text { iniciados em } 2002 \text { e } 2^{\text {a. }} \text { Geração }\end{array}$} & \multicolumn{2}{|c|}{ uh's } & \multirow[b]{2}{*}{$\begin{array}{l}\text { térmi- } \\
\text { no pre } \\
\text { visto }\end{array}$} & \multicolumn{2}{|c|}{ avanço financeiro } \\
\hline & concluí-das & viabili-zadas & & $\begin{array}{c}\text { previsto } \\
\text { até } \\
\text { dez/2003 }\end{array}$ & $\begin{array}{c}\text { verificado } \\
\text { em dez/2004 }\end{array}$ \\
\hline Autódromo ( II ) & & 32 & ñ disp. & ñ disponível & não disponível \\
\hline Barro Branco - Vida Nova (3ª etapa) & & 50 & 2004 & $44,59 \%$ & $19,74 \%$ \\
\hline Lapena (2a etapa) & 160 & 160 & 2004 & $40,39 \%$ & $99,99 \%$ \\
\hline Miguel Ackel - Clube de Mães ( $2^{a}$ etapa) & & 60 & 2004 & $21,81 \%$ & $12,01 \%$ \\
\hline Miguel Ackel - Vila Simone ( $2^{a}$ etapa) & & 60 & 2004 & $21,54 \%$ & $11,73 \%$ \\
\hline S. Etelvina - Barro Branco I, II e IV (3a etapa) & & 150 & 2004 & $34,48 \%$ & $67,63 \%$ \\
\hline S. Etelvina - Barro Branco III (3ªtapa) & 50 & 50 & 2004 & $34,48 \%$ & $67,68 \%$ \\
\hline Valo Velho I - União de Todos (2ª etapa) & & 80 & 2005 & $16,25 \%$ & não disponível \\
\hline Valo Velho I - Unidos Venceremos ( $2^{a}$ etapa) & & 80 & 2005 & $16,25 \%$ & não disponível \\
\hline City Jaraguá & 180 & 180 & 2005 & $28,25 \%$ & $100,00 \%$ \\
\hline Inácio Monteiro - Paulo Freire & 100 & 100 & 2005 & $30,77 \%$ & $62,08 \%$ \\
\hline Inácio Monteiro - Unidos Venceremos & & 100 & 2005 & $30,12 \%$ & $37,97 \%$ \\
\hline Jardim Bela Vista & 160 & 160 & 2005 & $30,30 \%$ & $62,39 \%$ \\
\hline Jardim Celeste V - Imaculada Conceição & & 100 & 2005 & $4,54 \%$ & $13,73 \%$ \\
\hline Jardim Educandário - Recanto da Felicidade & & 160 & 2005 & $30,75 \%$ & $\begin{array}{c}18,07 \% \text { (120uh), } \\
83,58 \% \text { (40uh) }\end{array}$ \\
\hline Jardim Marabá - Ernesto Che Guevara & & 120 & 2005 & $20,78 \%$ & $36,53 \%$ \\
\hline Minas Gás - Bela Vitória & 80 & 80 & 2005 & $26,96 \%$ & $86,66 \%$ \\
\hline Parque Europa I & & 680 & 2005 & $16,63 \%$ & $40,92 \%$ \\
\hline S. Etelvina - Irmã Lucinda & 60 & 60 & 2004 & $45,84 \%$ & $96,78 \%$ \\
\hline Sítio Conceição - Santa Luzia & & 175 & 2005 & $10,97 \%$ & $34,65 \%$ \\
\hline Total & 790 & 2.637 & & & \\
\hline
\end{tabular}

Fonte: FMH, Acomp. da Execução do Plano de Metas 2001-2004 (1 ${ }^{\text {a. }}$ Reunião Ordinária do CMH-julho/03) e COHAB-SP, Relatório de Gestão 2001-2004, 2004, p. 6, e relatórios gerenciais, 2004

E no caso da $3^{a}$. Geração, os serviços realizados em relação a esses empreendimentos foram, basicamente, os de montagem dos convênios, regimentos, etc., elaboração de projetos, a instalação de canteiros, e, portanto, os dados de avanço financeiro não podem ser relacionados a um avanço das obras, que, praticamente, não foram iniciadas.

Apesar de dados de avanço financeiro não indicarem tão bem o efetivo avanço da obra, quanto dados do avanço físico, eles permitem uma idéia relativa do andamento. Os dados referentes à $2^{\mathrm{a}}$. Geração mostram que o desenvolvimento desses empreendimentos esteve aquém do que se esperava.

73 Todas as obras da $1^{\text {a }}$. Geração iniciadas entre 89 e 92 foram concluídas até dezembro/2004, exceto N. Sra. da Penha $-2^{a}$. etapa, que, pela descoberta de problemas de contaminação do solo e de ocorrência de gases, teve que ser paralisada, enquanto eram feitas prospecções, diagnósticos e, depois, obras de remediação. Para o empreendimento havia um parecer favorável da CETESB, emitido na década de 80. 
Tabela 5.8

\begin{tabular}{|c|c|c|}
\hline \multirow{2}{*}{$\begin{array}{l}\text { Empreendimentos do Programa de } \\
\text { Mutirões com Autogestão }-3^{\text {a. }} \text { Geração }\end{array}$} & \multicolumn{2}{|c|}{ uh's } \\
\hline & concluídas & viabilizadas \\
\hline Antônio França 1 & & 100 \\
\hline Antônio França 2 & & 100 \\
\hline Barro Branco I - MST de São Miguel & & 240 \\
\hline Barro Branco II-a & & 160 \\
\hline Barro Branco II-b & & 260 \\
\hline Barro Branco II-c & & 160 \\
\hline Elza Guimarães & & 100 \\
\hline Estevão Rezende - UMT Pq. Conquista & & 120 \\
\hline Ferreirópolis - Terra Nossa/ Vento Leste & & 180 \\
\hline Guarapiranga - I - FACESP & & 200 \\
\hline Guarapiranga - II - Vento Leste & & 80 \\
\hline Heliópolis A - UNAS & & 40 \\
\hline Inácio Monteiro - Casa Branca & & 200 \\
\hline Inácio Monteiro - Flor do Oriente & & 40 \\
\hline Jardim João XXIII - ATST Zona Oeste & & 150 \\
\hline Joaquim Leal - MST São Miguel & & 23 \\
\hline Mendonça Júnior - ATST Zona Oeste & & 100 \\
\hline Mendonça Júnior - Fórum de Mutirões & & 100 \\
\hline $\begin{array}{l}\text { Minas Gás - Fórum dos Mutirões / Assoc. N.S. } \\
\text { das Graças }\end{array}$ & & 100 \\
\hline Parque Boa Esperança - Fórum de Mutirões & & 160 \\
\hline Rodolfo Pirani & & 16 \\
\hline Santa Etelvina I-VI A A - Flor do Oriente & & 100 \\
\hline Santa Etelvina I-VI A B - Pq. das Andorinhas & & 100 \\
\hline São Francisco - A - ATST Leste I & & 190 \\
\hline São Francisco - B - Fórum de Mutirões & & 150 \\
\hline São Francisco - C - Pq. das Andorinhas & & 80 \\
\hline Sonda B - MST Zona Norte & & 100 \\
\hline Tuparoquera A - União Força e Terra & & 120 \\
\hline Tuparoquera B - I - Fórum de Mutirões & & 80 \\
\hline Tuparoquera B - II - Vento Leste & & 40 \\
\hline Vale das Flores - ATST Zona Oeste & & 63 \\
\hline Vila Mara - SALVE/Ong. DCT & & 100 \\
\hline Vila Torinto/IV Centenário & & 160 \\
\hline Virgilia Rodrigues & & 400 \\
\hline Total & & 4.312 \\
\hline
\end{tabular}

Fonte: COHAB-SP, Relatório de Gestão 2001-2004, 2004, p. 6

Tabela 5.9

\begin{tabular}{c|r|r}
\hline \multirow{2}{*}{$\begin{array}{c}\text { Empreendimentos do Programa de } \\
\text { Mutirões com Autogestão }\end{array}$} & \multicolumn{2}{|c}{ uh's } \\
\cline { 2 - 3 } & concluídas & viabilizadas \\
\hline 1a. Geração & 6.657 & 6.795 \\
\hline 1a. Geração Novas Etapas e 2a. Geração & 790 & 2.637 \\
\hline 3a. Geração & 0 & 4.312 \\
\hline Total & 7.447 & 13.744 \\
\hline
\end{tabular}

Fonte: COHAB-SP, Relatório de Gestão 2001-2004, 2004, p. 6 
Dentre os empreendimentos de $1^{\mathrm{a}}$. Geração Novas Etapas e de $2^{\mathrm{a}}$. Geração, o City Jaraguá, Inácio Monteiro/Paulo Freire, Jd. Bela Vista, Jd. Educandário, Lapena, Minas Gás, S. Etelvina/Barro Branco III, e S. Etelvina/Irmã Lucinda, que somavam 950 uh's (36\% do total), tiveram desempenho de obra próximo ao que se previa no planejamento apresentado na $1^{\text {a }}$. Reunião Ordinária do $\mathrm{CMH}$, em julho de 2003. Tendo sido concluídos no ano previsto ou antes dele, ou tiveram evolução que permitia que se acreditasse na conclusão no prazo previsto. Evidentemente, que não é satisfatória uma previsão de término de obra que apenas indique o ano. Mas foi a que se apresentou para o Conselho Municipal de Habitação e é a que dispomos para efetuar essa comparação entre realizado e previsto.

Os empreendimentos Inácio Monteiro/U. Venceremos, Jd Marabá, Pq. Europa I, S. Etelvina/B. I, II e IV (3 ${ }^{a}$ etapa) e Sítio Conceição, com um total de 1225 $(46,45 \%$ do total), tiveram desempenho abaixo do que seria de se esperar, mas que, no entanto, permitia acreditar em uma recuperação.

Já os empreendimentos Barro Branco/V. Nova, Miguel Ackel/Clube de Mães, Miguel Ackel/V. Simone, e Jd. Celeste V, que envolviam 270 uh's (10\% do total), tiveram desempenho muito fraco e grande atraso.

Pode-se dizer que existem divergências importantes entre concepções em torno do Programa de Mutirões com Autogestão, que muitas vezes contribuem para embaraçar o seu andamento. Que, na maior parte do tempo, ficam subjacentes, mas, às vezes, se explicitam. Essas divergências decorrem, a meu ver, principalmente, de uma dificuldade de se compatibilizar o rigor exigido na administração dos recursos públicos com a flexibilidade desejada para a autogestão; e, ainda, da normal dificuldade de relacionamento entre contratados e contratantes, que se verifica também, por exemplo, entre escritórios de projeto em trabalhos mais convencionais e os técnicos que representam o contratante, e que analisam esses projetos e os aprovam.

$\mathrm{Na}$ execução do programa, não basta que as associações empreguem todos os recursos recebidos na obra. É obrigatório que também realizem prestações de contas, demonstrando como todos os recursos foram aplicados, e isso 
exatamente da forma como especificado nas normas do programa. As prestações de contas condicionam a liberação das parcelas do financiamento às associações, evidentemente, que com a exceção da primeira parcela. $E$ os freqüentes atrasos ou na apresentação das prestações de contas pelas associações ou na sua aprovação pela $\mathrm{COHAB}$, implicam em atraso na liberação de parcelas do financiamento e, portanto, em atraso da obra.

Não são aceitas prestações de contas com notas faltantes ou não emitidas corretamente. Preparar uma prestação de contas, que tenha a precisão necessária, é uma atividade que exige uma boa organização das associações, mas que, nem sempre, reflete uma correta aplicação de recursos. Podem ocorrer situações em que todos os recursos estejam aplicados na obra corretamente e que a prestação de contas esteja incorreta. Como, também, pode ocorrer da prestação de contas estar perfeita, mas que parte dos recursos tenham sido utilizados em desconformidade com os objetivos do convênio e essa situação não seja detectada na prestação de contas.

A prestação de contas é um ato mais (ou apenas) contábil, no qual a grande exigência é a de que as notas estejam corretas. Ainda não foi adotado um procedimento de checagem das despesas realizadas em relação ao que está definido nos projetos, memoriais descritivos, orçamentos e demais especificações técnicas, para cada obra. O que permite que as associações possam executar compras em desacordo com os elementos técnicos em vigor e isso não seja percebido na prestação de contas. Por exemplo, não se verifica se os cabos elétricos foram comprados de acordo com o valor orçado e com o cronograma de obras; ou se foram comprados antes de feitas as fundações, como ocorreu por associação participante de empreendimento do Programa Paulista de Mutirões da CDHU, em que, em conseqüência disso, faltaram recursos para as fundações.

Nabil Bonduki, Superintendente da HABI/SEHAB, durante a gestão de Luiza Erundina, e um dos principais responsáveis pela criação do Programa de Mutirões com Autogestão, em entrevista ao já mencionado caderno do Instituto Pólis (SILVA, 1994, p. 17), falou que o processo de prestação de contas, que seria um "nó" para o funcionamento do programa, pelas "enormes dificuldades" que as associações enfrentariam para fazê-las, é uma decorrência do entendimento do 
Tribunal de Contas do Município de que o repasse de recursos que ocorre caracterizaria uma subvenção, o que tornaria obrigatória a prestação de contas. Para Bonduki, deveria ser buscada uma forma de funcionamento do programa semelhante às obras por empreiteira, com liberação de recursos baseada em medição posterior à execução dos serviços:

"Deve ser criado algum mecanismo que permita que uma primeira parcela de recursos possa ser repassada para a comunidade, a título de uma série de serviços que ela possa executar sem grande despesa monetária. Isso cria a possibilidade para que a comunidade possa produzir e receber recurso pelo que ela produziu".

Segundo ele, não houve tempo de realizar essa mudança na gestão Erundina. Essa opinião a respeito da dificuldade da prestação de contas e da importância de que houvesse um outro modo de medir os serviços realizados por autogestão ainda é mantida por Bonduki, conforme entrevista informal concedida ao autor desta dissertação, no início de 2007.

Na gestão 2001-2004, as mudanças realizadas nas regras do programa não alteraram a necessidade das prestações de contas. Esse é outro aspecto que não se conseguiu solucionar de forma a eliminar arestas importantes, que tendem a embaraçar o programa

A mencionada dificuldade de se compatibilizar as lógicas do serviço público e das associações que participam dos programas de autogestão, de compatibilizar o rigor necessário na administração dos recursos públicos com a flexibilidade desejada na autogestão, nem sempre tem sido considerada por aqueles que têm estudado o programa. E é muito comum que as suas dificuldades do sejam atribuídas a um viés ideológico, a uma rejeição, por parcela dos funcionários dos órgãos ou empresas públicos, da idéia de que movimentos populares controlem os recursos para a execução das obras; ou como uma dificuldade que parcela dos funcionários teriam em partilhar o seu poder de decisão sobre a aplicação de recursos públicos, sobre as características dos projetos, sobre a gestão da obra, sobre a organização autônoma da associação (a velha tecnocracia). Como ranzinzice, indisposição, antipatia em relação ao programa. 
Decerto isso também existe mesmo. Mas nem todos os funcionários que têm ponderações a fazer em relação ao programa são avessos a ele e muito menos avessos à organização popular autônoma.

O debate em torno dos rumos do programa, da necessidade de ajustes, muitas vezes toma um caráter profundamente ideológico, apaixonado e, em muitas cabeças, os vários personagens acabam sendo alinhandos em um dos dois "partidos" cuja existência parece possível: os "pró" e os "contra" os mutirões com autogestão.

Existem alguns problemas reais, cuja solução é fundamental para que os empreendimentos do programa fluam com maior normalidade, para que tenham maior celeridade. É importante que se busque equacioná-los, que sejam abordados da forma menos ideologizada possível.

Existem procedimentos em relação aos quais o Estado e seus representantes legais não podem se esquivar, se eximir. Se uma obra apresentar problemas técnicos ou uma inadequação às exigências legais, a solução desses problemas caberá também à administração pública e aos técnicos designados para representá-la. Pois não há como o poder público estabelecer com uma associação a mesma espécie de relação que estabelece com uma empresa contratada. Dentre outras coisas, porque ele não poderá acionar juridicamente a associação para que refaça a obra, às suas expensas. A associação não terá recursos para fazê-lo.

A associação não possui bens e não há como exigir que os seus dirigentes sejam responsabilizados individualmente por eventuais problemas e, mesmo que houvesse, não seria possível tornar efetiva essa exigência, pois grande parte desses dirigentes não possuem bens que possam ser oferecidos em garantia.

Não se pode supor que a mesma pureza de propósitos que havia nas associações, no início do programa de mutirões com autogestão, teria sido mantida 12 anos depois. Nesse período, o mundo mudou muito. Houve uma exacerbação dos estímulos à competição, uma perda de importância dos valores da cooperação, principalmente, como uma das resultantes da ascensão do ideário neoliberal. $O$ pragmatismo ganhou espaço no meio político brasileiro e parece que, também, no mundial; houve um declínio das ideologias; foram deixados em posição secundária 
projetos mais generosos, projetos de mudanças mais profundas; mesmo no PT, partido em que, por muito tempo, houve um grande cuidado para evitar um descolamento entre a prática e a teoria, e com o qual se identificavam boa parte das lideranças dos movimentos por habitação. Não se poderia pensar que apenas os movimentos por moradia ficassem a salvo dessas mudanças e que, neles, sempre os interesses coletivos fiquem acima dos individuais.

Que fique claro que não se está dizendo que todas, ou um número grande ou pequeno de associações foram tomadas pelo pragmatismo e pelos interesses particulares, inclusive porque uma afirmação como essa teria que se basear numa pesquisa que não foi feita por este trabalho. Mas se está dizendo que não se deveria antepor a quaisquer propostas que apontem para mudanças no programa de mutirões com autogestão, que visem dar maior transparência aos seus controles, o argumento de que tais controles, primeiro, são desnecessários e, segundo, nocivos para a autonomia e para a agilidade das associações.

Também não se está propondo a ampliação dos controles, um aumento das amarrações do programa, mas, sim, que se está propondo que haja um debate franco onde não predominem os viéses ideológicos e que se busque propiciar melhorias ao programa, no sentido de torná-lo mais transparente, melhorar a clareza das responsabilidades, o grau de confiança que há em torno dele. Mas, também, que seja desembaraçado de exigências inúteis e ganhe agilidade. 


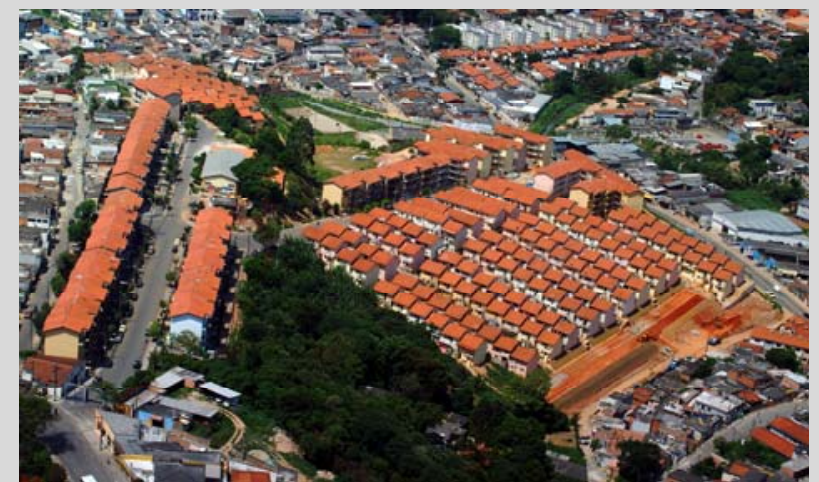

Jardim Apuanã - vista aérea (foto: arquivo Cohab) Projeto: Assessoria Técnica a Movimentos Populares $1^{a}$ geração

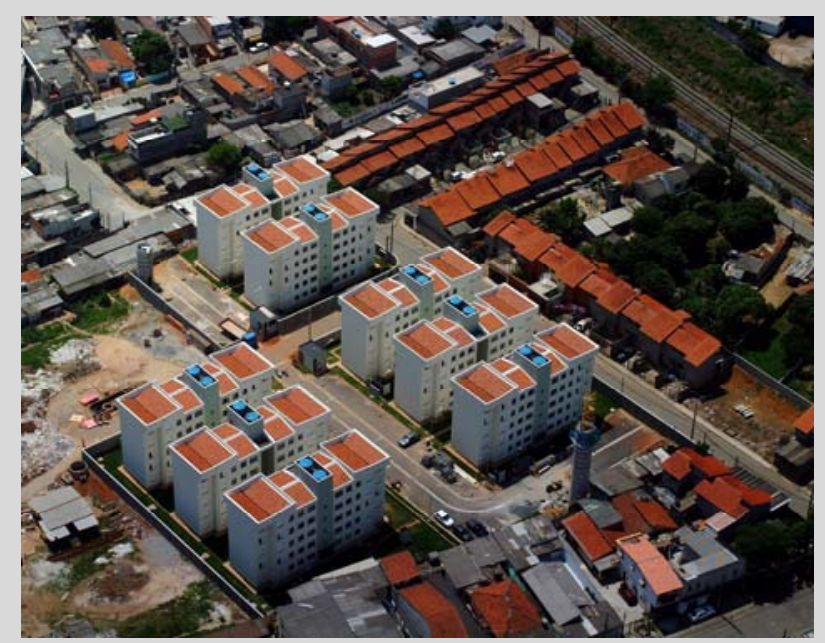

Lapena - vista aérea (foto: Robson Martins)- Projeto: Teto - Assessoria Técnica a Movimentos Populares - $1^{\text {a }}$ geração

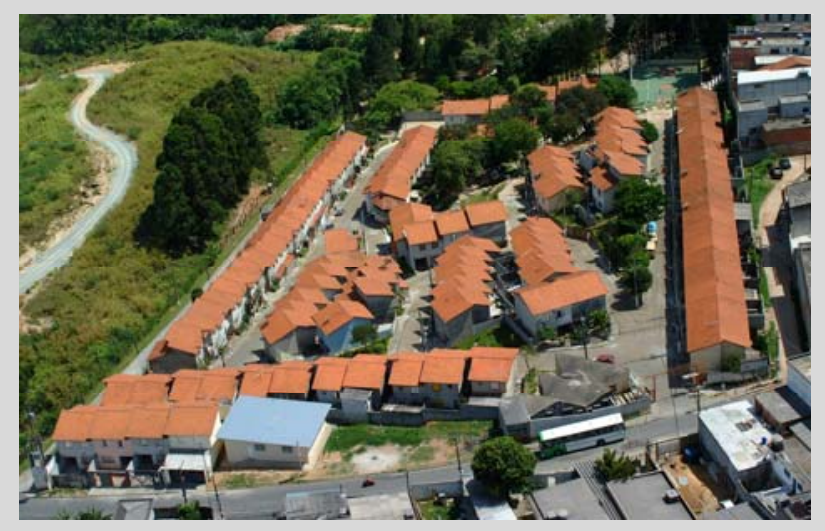

Vista Linda - vista aérea - (foto: Robson Martins)Projeto: Oficina de Habitação / Peabirú - $1^{a}$ geração

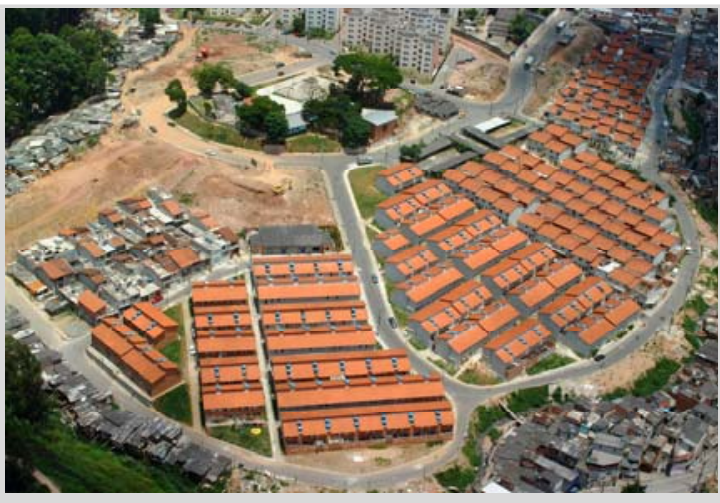

Jardim Celeste I e II - vista aérea (foto: Robson Martins)

- Projeto: Caap - Centro de Assessoria à Auto Gestão Popular - $1^{a}$ geração

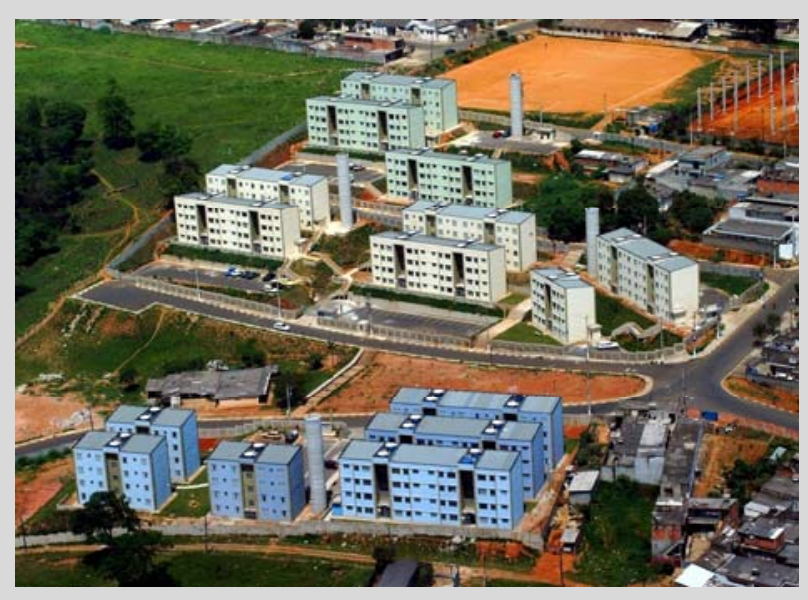

Lírios do Itaim - visa aérea(foto: Robson Martins)Projeto: Teto - Assessoria Técnica a Movimentos Populares $-1^{a}$ geração

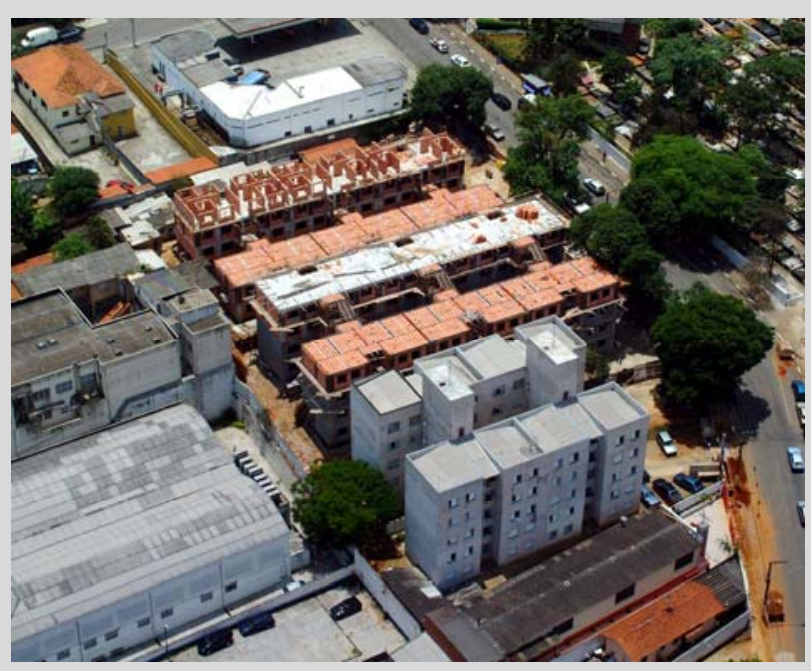

Jardim Bela Vista - vista aérea - (foto: Robson Martins)Projeto: Norte - Assessoria Técnica a Movimentos Populares - $2^{a}$ geração 


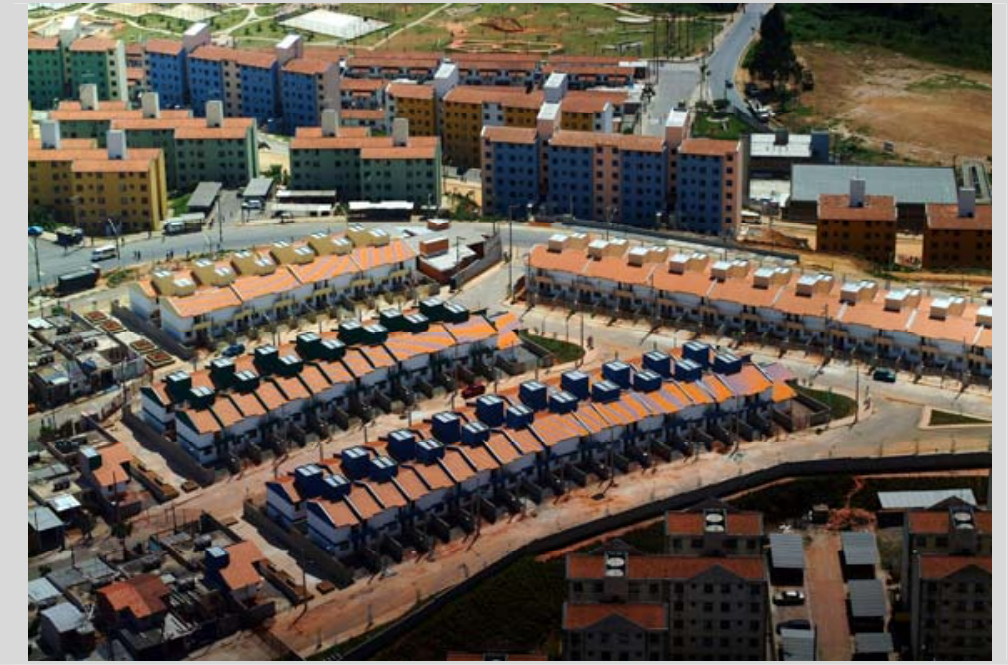

City Jaraguá - vista aérea - (foto: arquivo COHAB)- Projeto: Ambiente Trabalhos para o Meio Habitado - 2a geração

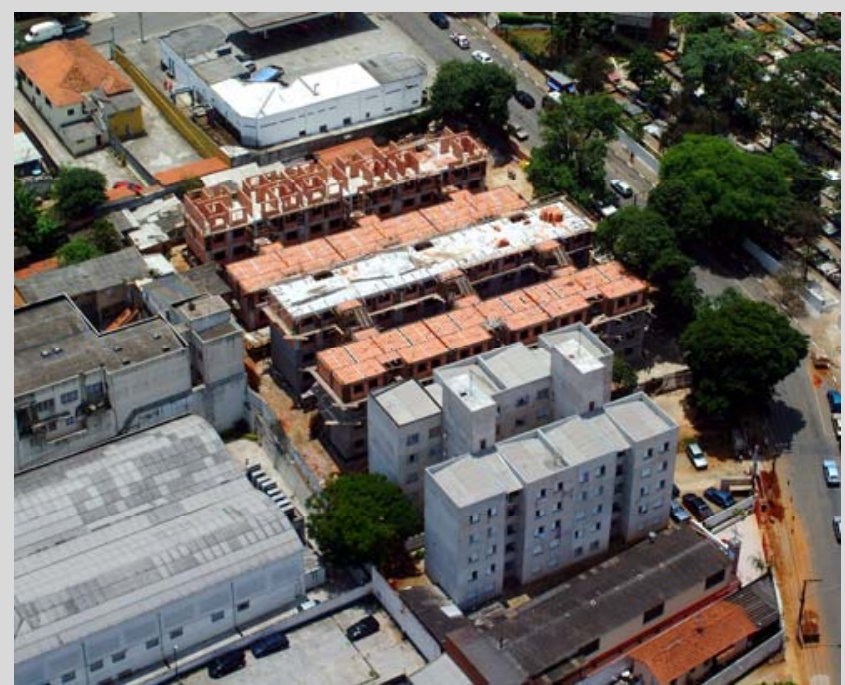

Jardim Bela Vista - vista aérea - (foto: arquivo COHAB)-

Projeto: Norte Assessoria Técnica a Movimentos Populares $2^{a}$ geração

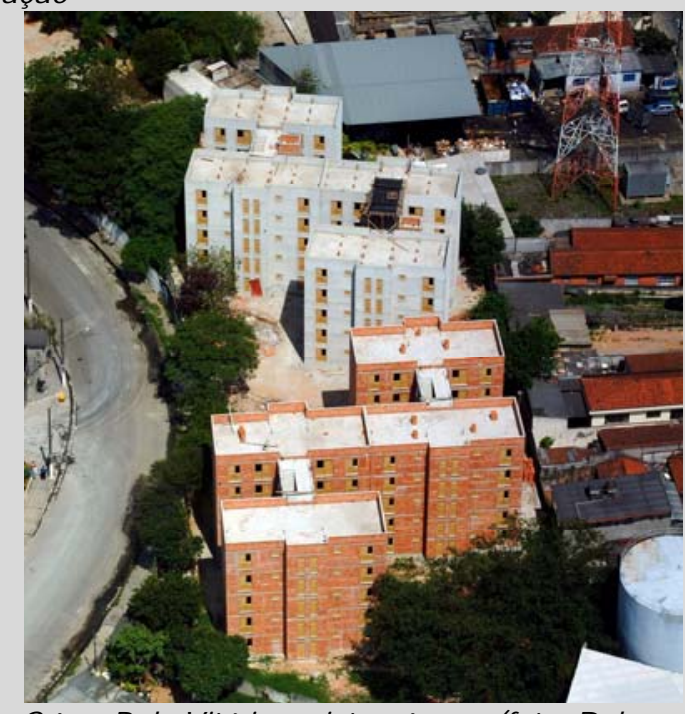

Minias Gás - Bela Vitória - vista aérea - (foto: Robson Martins) - Projeto: Habitar Assessoria Técnica Ltda. - $2^{a}$ geração

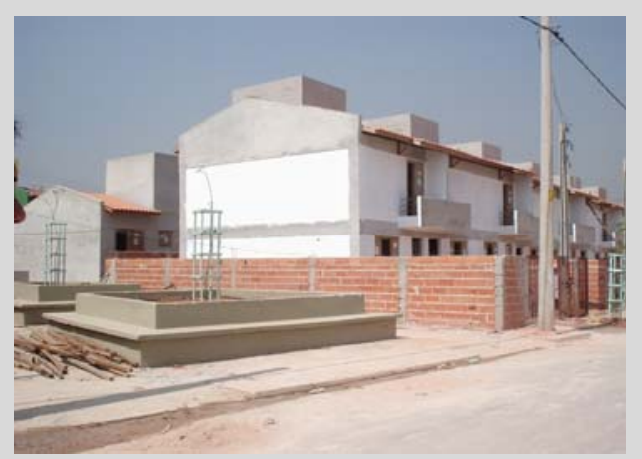

City Jaraguá - construção das unidades habitacionais - (foto: arquivo COHAB)

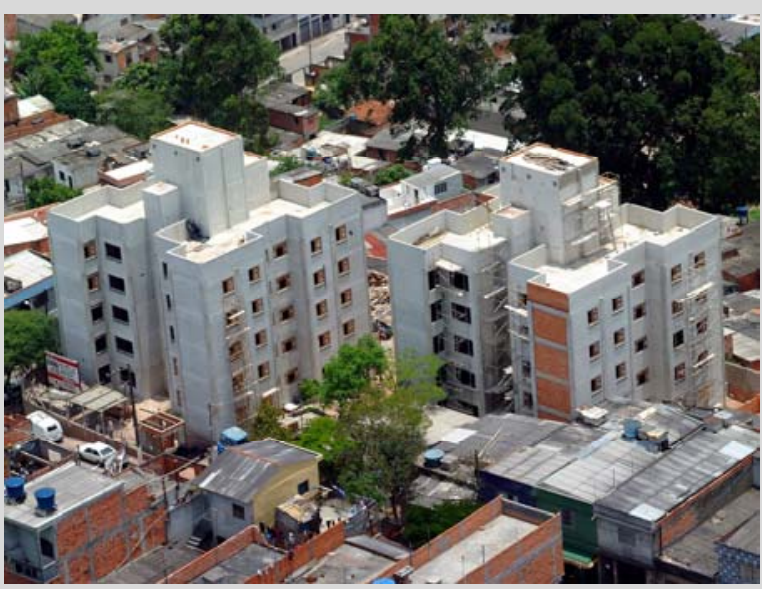

Jardim Educandário - Recanto da Felicidade - vista aérea (foto: arquivo $\mathrm{COHAB}$ ) - Projeto: Peabirú Trabalhos Comunitários e Ambientais - $2^{a}$ geração

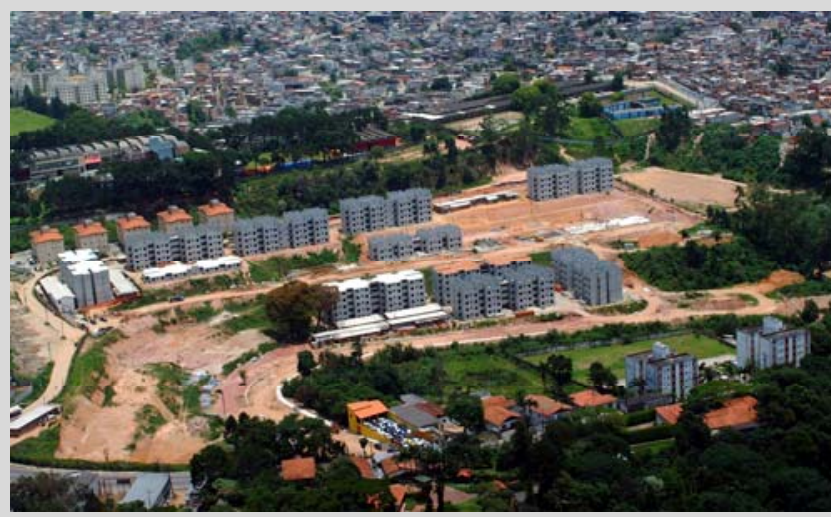

Parque Europa - vista aérea - (foto: Robson Martins) Projeto:GTA Grupo Técnico de Apoio - $2^{a}$ geração 


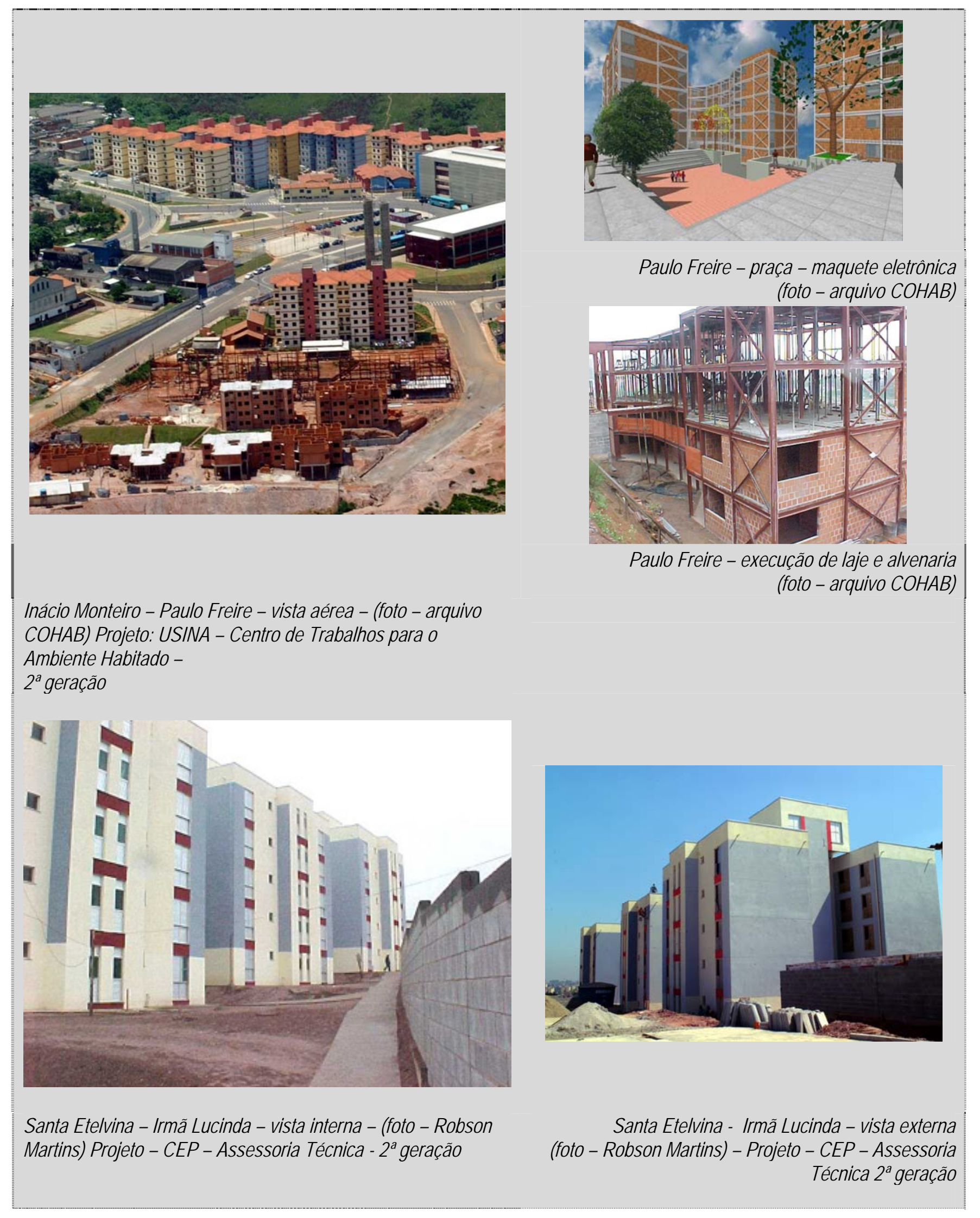




\subsection{O Programa de Arrendamento (PAR) em parceria com a CEF}

“O PAR é um programa do Governo Federal, criado em 10. de junho de 1999, por Medida Provisória, que foi convertida na Lei no 10.188, de 12 de fevereiro de 2001. Tem como agente gestor a Caixa Econômica Federal (CEF). Destina-se à construção e reforma de moradias, prioritariamente situadas em grandes cidades, para arrendamento por 15 anos a famílias com renda inferior ou igual a 6 salários mínimos, com opção de compra ao final do período.

As famílias pagam taxas mensais de arrendamento com valores iguais a 0,7\% do preço da moradia. A partir de alterações promovidas pelo Ministério das Cidades, que, desde sua criação no início de 2003, passou a definir as diretrizes gerais do Programa, permitiu-se que a taxa de arrendamento passasse a 0,5\%, desde que a renda da família atendida fosse de, no máximo, 4 salários mínimos e o valor da unidade igual ou menor a $R \$$ 29.000. Em função dos valores atingidos pelas unidades, previa-se que, na Cidade de São Paulo, a aplicação da taxa de 0,5\% ocorresse apenas para parcela dos apartamentos de menor área, em prédios em reforma no Centro.

Os recursos do PAR são provenientes do Fundo de Arrendamento Residencial (FAR), que, por sua vez, foi composto com recursos de outros fundos (FAS, FINSOCIAL, PROTECH, FDS), mas, principalmente, do FGTS" (escrito por este autor para o “Relatório de Gestão 2001-2004”, publicado pela COHAB-SP, em 2004).

A COHAB havia firmado, em 21 de dezembro de 1999, durante a gestão Pitta, um convênio com a CEF para implantação do Programa de Arrendamento Residencial (PAR). No entanto, até o início de 2001, este convênio não havia resultado na contratação de nenhuma obra.

Conforme dito anteriormente, desde o início da gestão Marta, a SEHAB e a COHAB haviam definido que buscariam a parceria com a CEF, para viabilizar o PAR, dentro de um conjunto de esforços para alavancar financiamentos para habitação a partir de fontes externas ao Orçamento Municipal. Em 21 de maio de 2001, a Prefeitura de São Paulo, a SEHAB e a COHAB-SP assinaram com a CEF novo convênio para implementação desse programa na Cidade de São Paulo. 
Para concretizar o que o convênio objetivava, a COHAB-SP passou a realizar estudos de viabilidade e seleção de terrenos de que dispunha em seu patrimônio. A maioria das áreas escolhidas foram lotes livres remanescentes em conjuntos já implantados. Esses terrenos seriam vendidos ao FAR (Fundo de Arrendamento Residencial) a preço de mercado, após um processo de compatibilização dos valores resultantes das avaliações feitas, separadamente, pela COHAB-SP e pela CEF. Em meados de 2001, a COHAB-SP destinou ao programa áreas que totalizavam 268.769,93 $\mathrm{m}^{2}$, prevendo a construção de 5.032 unidades habitacionais.

Essas áreas eram constituídas de 77 lotes, dos quais 68 eram lotes livres remanescentes em 16 conjuntos habitacionais já implantados, 4 eram lotes que resultariam de um parcelamento de gleba em curso (Valo Velho II) e 5 resultariam de um desdobro que seria feito de um grande lote, também remanescente em loteamento já implantado (Itaquera IV).

Os 77 lotes foram reunidos em 33 agrupamentos visando a execução dos projetos e obras. Havia desde agrupamentos muito pequenos, com potencial para 20 e 40 apartamentos (agrupamentos 9 e 10 em S. Etelvina IIB e 11 e 12 em S. Etelvina VII), até agrupamentos com porte razoável, com potencial para mais de 540 e 550 apartamentos, no Valo Velho II (agrupamento 1) e em Itaquera IV (agrupamentos 32 e 33).

Em 5 de abril de 2002, a COHAB publicou edital de concorrência (no. 003/02) para escolha das construtoras que executariam as obras do programa. De acordo com esse edital, as empresas vencedoras receberiam um atestado que as credenciaria a apresentar à CEF propostas para empreendimentos a serem implantados nos terrenos de propriedade da COHAB. Caso a proposta fosse aceita pela CEF, seria firmado um contrato entre esse banco, a COHAB e a construtora. Contrato esse que formalizaria a alienação do terreno pela $\mathrm{COHAB}$ ao FAR, representado pela CEF, estabeleceria as obrigações e direitos da CEF como contratante da obra e da construtora como contratada.

O edital permitia que cada empresa ficasse responsável por, no máximo, dois agrupamentos ou 550 unidades habitacionais. E exigia, como condição para a 
habilitação, que demonstrassem que tinham sido aprovadas na análise feita pela Gerência de Risco de Crédito (GERIC), da Caixa Econômica Federal, além de exigir que apresentassem toda a documentação comumente solicitada nas licitações de obras. Cada empresa deveria indicar os agrupamentos pelos quais se interessavam e, se houvesse mais de uma interessada por agrupamento - o que, evidentemente, ocorreu -, a decisão seria feita por sorteio.

A licitação provocou o interesse de um grande número de empresas e 51 apresentaram propostas. Dessas 51, 23 foram selecionadas, sendo que 10 empresas ficaram responsáveis, simultaneamente, pelas obras de dois agrupamentos.

Ao final de 2004, 18 agrupamentos estavam com obras em estágio avançado (3.895 uh's), um estava com contrato assinado e com obra prestes a iniciar (80 uh's) e outro em fase adiantada de contratação (160 uh's). Num total de 4.135 uh's. Desses 20 agrupamentos com obras em curso ou viabilizadas, 4 passaram por uma substituição de empresas que desistiram (após terem sido selecionadas), por outras classificadas seqüencialmente na licitação.

A desistência de empresas selecionadas também envolveu outros 8 agrupamentos (361 uh's, segundo o potencial estimado inicialmente). Nesses, não houve como promover uma substituição, por falta de interessados em 7 dos casos, e pelo fato de um deles ter o terreno cortado por uma adutora e de outro estar sendo utilizado por uma igreja. As desistências e a dificuldade de conseguir as substituições decorreram, sobretudo, do pequeno porte dos agrupamentos (entre 19 e 76 uh's, conforme potencial estimado inicialmente). Num dos casos (o de 76 uh's), o que havia de desinteressante para as construtoras no pequeno porte era agravado pelo fato de também ser necessária, para o aproveitamento do terreno, a construção de edifício com elevadores, uma tipologia não utilizada usualmente pelas construtoras no segmento de HIS.

Não por desistência, mas porque os valores de construção somados aos dos terrenos superaram aos valores máximos admitidos para o Programa, 5 agrupamentos (876 uh's) não foram viabilizados e 1 agrupamento não foi viabilizado parcialmente (80 uh's). 
Ao final de 2004, 75\% $\left(201.360,82 \mathrm{~m}^{2}\right)$ das áreas disponibilizadas para o PAR pela COHAB $\left(268.769,93 \mathrm{~m}^{2}\right)$ haviam sido aproveitadas. Mas, em número de unidades habitacionais, havia se chegado a $82 \%$ (4135 uh's) do que se esperava produzir com o programa, quando do lançamento do edital (5.032 uh's). A diferença entre essas porcentagens foi conseqüência, principalmente, do maior adensamento conseguido pelos projetos apresentados pelas construtoras, em relação aos estudos de potencial realizados pela COHAB.

As empresas selecionadas para cada um dos agrupamentos tinham como obrigação a elaboração e apresentação, para a CEF, dos projetos (devidamente aprovados pelos órgãos competentes), memoriais descritivos, orçamentos e cronograma físico-financeiro, em um prazo de 60 dias, contados de 23 de julho de 2002, data da entrega do Atestado de Seleção pela COHAB.

Esse prazo, depois, verificou-se muito exíguo e sua dilatação foi objeto de vários aditamentos. O primeiro contrato para a execução de obra foi firmado em 3 de setembro de 2003 - 407 dias depois do início do processo (entrega do Atestado de Seleção) -, com a Construtora Croma e teve como objeto a execução de 200 apartamentos em 3 condomínios em lotes remanescentes do C.H. Teotônio Vilela. E a última assinatura de contrato, na gestão Marta Suplicy, aconteceu em $1^{\circ}$. de dezembro de 2004 - 862 dias depois do início do processo -, quando foi contratada a Construtora Menin, para a execução de 80 apartamentos em 2 condomínios em lotes remanescentes do C.H. Jardim Antártica. Foi de 522 dias o tempo médio entre a emissão do Atestado de Seleção, que marcava o início dos trabalhos das construtoras, e a assinatura dos contratos entre cada uma delas, a CEF e a COHAB$\mathrm{SP}$, que marcava o início da obra. 
Tabela 5.10 - PAR-COHAB - Construção: Empreendimentos, nº uh's, áreas dos terrenos, valores, etc.

\begin{tabular}{|c|c|c|c|c|c|c|c|c|c|c|c|}
\hline $\begin{array}{l}\text { CONJUNTO } \\
\text { HABITACIONAL }\end{array}$ & DISTRITO & TIPOLOGIA & $\begin{array}{l}\text { ÁREA DO } \\
\text { TERRENO } \\
\left(\mathbf{M}^{2}\right)\end{array}$ & $\mathrm{N}^{\circ}$ UH's & $\begin{array}{l}N^{\circ} \text { CONDO } \\
\text { MÍNIOS }\end{array}$ & 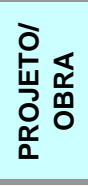 & VALOR & CONTRATADA & $\begin{array}{l}\text { DATA DE } \\
\text { INÍCIO }\end{array}$ & $\begin{array}{l}\text { DATA DE } \\
\text { TÉRMINO }\end{array}$ & $\begin{array}{l}\text { \% DOS } \\
\text { SERVI- } \\
\text { ÇOS JÁ } \\
\text { EXECU- } \\
\text { TADOS }\end{array}$ \\
\hline BARRO BRANCO II & Cid. Tiradentes & "H" c/ 20 uh's em 5 pavs. & $11.605,00$ & 200 & 2 & $\mathrm{O}$ & $6.367 .519,65$ & C.A.L. & 10-mar-04 & 10-mar-05 & $86,9 \%$ \\
\hline \multirow{2}{*}{ INÁCIO MONTEIRO } & Cid. Tiradentes & "H" c/ 20 uh's em 5 pavs. & $11.463,56$ & 200 & 3 & $\mathrm{O}$ & $6.091 .483,01$ & MVG & 18-nov-03 & 20-dez-04 & $77,5 \%$ \\
\hline & Cid. Tiradentes & "H" c/ 20 uh's em 5 pavs. & $9.439,68$ & 160 & 3 & $\mathrm{O}$ & $4.974 .264,96$ & GARDEN & 30-dez-03 & 23-fev-05 & $76,4 \%$ \\
\hline \multirow{2}{*}{ ITAQUERA IV } & José Bonifácio & "H" c/ 20 uh's em 5 pavs. & $27.757,43$ & 540 & 3 & $\mathrm{O}$ & $17.387 .709,31$ & BLOKOS & $30-a b r-04$ & 30-abr-05 & $52,9 \%$ \\
\hline & José Bonifácio & "H" c/ 20 uh's em 5 pavs. & $27.359,40$ & 560 & 4 & 0 & $18.026 .247,29$ & SERGUS & $30-a b r-04$ & 30-abr-05 & $48,7 \%$ \\
\hline JD. ADVENTISTA & Capão Redondo & "H" c/ 20 uh's em 5 pavs. & $8.248,58$ & 170 & 3 & $\mathrm{O}$ & $5.429 .761,97$ & SUPREMA & 30-dez-03 & 28-fev-05 & $36,6 \%$ \\
\hline JD. ANTÁRTICA & Cachoeirinha & "H" c/ 20 uh's em 5 pavs. & $4.206,02$ & 80 & 2 & $\mathrm{O}$ & $2.571 .733,57$ & CONSTR. MENIN & 01-dez-04 & 01-dez-05 & $0,0 \%$ \\
\hline \multirow{4}{*}{ JOSÉ BONIFÁCIO } & José Bonifácio & "H" c/ 20 uh's em 5 pavs. & $1.424,40$ & 40 & 1 & $\mathrm{O}$ & $1.208 .700,24$ & CONSTRUMÁTICA & 19-set-03 & 20-dez-04 & $87,5 \%$ \\
\hline & José Bonifácio & "H" c/ 20 uh's em 5 pavs. & $4.873,73$ & 140 & 1 & $\mathrm{O}$ & 4.423.156,44 & MVG & 9-out-03 & 9-jan-05 & $65,9 \%$ \\
\hline & José Bonifácio & "H" c/ 20 uh's em 5 pavs. & $13.551,83$ & 300 & 1 & $\mathrm{O}$ & $9.655 .793,53$ & DESIGN & 30-dez-03 & 30-dez-04 & $83,0 \%$ \\
\hline & José Bonifácio & $\begin{array}{c}11 \text { pavs, } 8 \text { por andar, } 7 \text { no } \\
\text { térreo }\end{array}$ & $2.884,67$ & 87 & 1 & $\mathrm{O}$ & $2.746 .563,68$ & ESTETO & 30-dez-03 & 30-dez-04 & $46,3 \%$ \\
\hline S. ETELVINA I - VI A & Cid. Tiradentes & "H" c/ 20 uh's em 5 pavs. & $8.941,36$ & 140 & 1 & $\mathrm{O}$ & $4.501 .653,41$ & CONSTRUMÁTICA & 30-dez-03 & 30-dez-04 & $73,0 \%$ \\
\hline \multirow{2}{*}{ S. ETELVINA II A } & Cid. Tiradentes & 10 pavs, 4 por andar & $9.938,63$ & 280 & 2 & $\mathrm{O}$ & $8.802 .829,15$ & DELTA & 30-dez-03 & 28-abr-05 & $75,1 \%$ \\
\hline & Cid. Tiradentes & "H" c/ 20 uh's em 5 pavs. & $8.480,09$ & 160 & 2 & $\mathrm{O}$ & $5.152 .000,00$ & GARDEN & até dez/04 & $\begin{array}{l}\text { prev. dez- } \\
05\end{array}$ & $0,0 \%$ \\
\hline \multirow[t]{2}{*}{ S. ETELVINA VII } & Cid. Tiradentes & $\begin{array}{c}10 \text { pavs, } 4 \text { por andar, } 3 \text { no } \\
\text { térreo }\end{array}$ & $1.969,77$ & 78 & 1 & $\mathrm{O}$ & $2.511 .600,00$ & AGH & 18-out-04 & 18-out-05 & $0,0 \%$ \\
\hline & Cid. Tiradentes & 10 pavs, 4 por andar & $2.083,75$ & 40 & 1 & $\mathrm{O}$ & $1.265 .975,56$ & DELTA & 30-dez-03 & 28-mar-05 & $76,6 \%$ \\
\hline \multirow{3}{*}{ TEOTÔNIO VILELA } & Sapopemba & "H" c/ 20 uh's em 5 pavs. & $5.396,34$ & 100 & 3 & $\mathrm{O}$ & $3.185 .099,11$ & A.G.H. & 19-set-03 & 20-dez-04 & $95,0 \%$ \\
\hline & Sapopemba & "H" c/ 20 uh's em 5 pavs. & $7.956,19$ & 160 & 2 & 0 & $5.149 .363,82$ & DESIGN & 18-nov-03 & 20-dez-04 & $92,3 \%$ \\
\hline & Sapopemba & "H" c/ 20 uh's em 5 pavs. & $8.797,76$ & 200 & 3 & $\mathrm{O}$ & $6.423 .440,80$ & CROMA & 3-set-03 & 20-dez-04 & $94,0 \%$ \\
\hline \multirow[t]{2}{*}{ VALO VELHO II } & Capão Redondo & "U" c/ 50 uh's em 5 pavs. & $24.982,63$ & 500 & 5 & $\mathrm{O}$ & $16.098 .012,43$ & HTR & 30-dez-03 & 30-dez-04 & $89,8 \%$ \\
\hline & & SUBTOTAL & $201.360,82$ & 4.135 & 44 & 0 & $131.972 .907,93$ & & & & \\
\hline \multirow{2}{*}{$\begin{array}{c}\text { EDIFÍCIO SÃO PAULO } \\
\text { (ANTIGO HOTEL SÃO } \\
\text { PAULO) }\end{array}$} & \multirow[t]{2}{*}{ Sé } & \multirow{2}{*}{$\begin{array}{c}\text { aptos. conjugados e de } 1 \mathrm{e} \\
2 \text { dorms. - reforma }\end{array}$} & & \multirow[t]{2}{*}{152} & \multirow{2}{*}{1} & $\mathrm{P}$ & $149.708,33$ & $\begin{array}{c}\text { FÁBRICA URBANA e } \\
\text { YCON }\end{array}$ & & & \\
\hline & & & & & & $\mathrm{O}$ & $4.322 .913,64$ & SETA & 21-out-04 & 21-out-05 & $0,0 \%$ \\
\hline \multirow[t]{2}{*}{ EDIFÍCIO SÃO VITO } & \multirow[t]{2}{*}{ Sé } & \multirow[t]{2}{*}{$\begin{array}{c}\text { aptos. conjugados e de } 1 \mathrm{e} \\
2 \text { dorms. - reforma }\end{array}$} & \multirow[t]{2}{*}{$\ldots \ldots \ldots \ldots$} & \multirow[t]{2}{*}{375} & \multirow[t]{2}{*}{2} & $\mathrm{P}$ & $234.551,80$ & $\begin{array}{l}\text { CAPOTEI LOEB e } \\
\text { CONCREMAT }\end{array}$ & & & \\
\hline & & & & & & $\mathrm{O}$ & $11.271 .127,50$ & A CONTRATAR & a definir & a definir & \\
\hline & SUBTOTAL & & 527 & 3 & $\mathrm{P}+\mathrm{O}$ & \multirow{2}{*}{$15.978 .301,27$} & \multirow{2}{*}{\multicolumn{4}{|c|}{$\begin{array}{l}\text { OBS.:Os valores de obra incluem os valores de terreno, } \\
\text { taxas cartoriais, seguro de término de obra e, exceto nos } \\
\text { empreendimentos do PAR-Reforma, também os de projeto }\end{array}$}} \\
\hline & & & & & & & & & & & \\
\hline & & TOTAL & $201.360,82$ & 4.662 & 47 & $\mathrm{P}+\mathrm{O}$ & $147.951 .209,20$ & & & & \\
\hline
\end{tabular}


Esse tempo muito longo, de certa forma, frustrou aqueles que, como este autor, imaginavam que o processo até a contratação das obras ocorreria em tempo bem reduzido, contando com um grande interesse das construtoras, pois havia terrenos, a elas, já reservados e recursos praticamente garantidos; contando com a flexibilidade advinda da possibilidade das construtoras contratarem e aprovarem os projetos diretamente; e contando com um empenho redobrado dos órgãos de licenciamento da SEHAB, já que os empreendimentos faziam parte de um programa da própria Secretaria.

A autonomia que se acreditava que as construtoras teriam e que deveria dar agilidade ao programa, ficou distante do que se esperava e era razoável supor. E verificou-se a necessidade da COHAB-SP, num primeiro momento, e da CEF, num segundo momento, exercerem um forte monitoramento/ coordenação das atividades que antecediam e condicionavam a contratação das obras e eram de responsabilidade tanto dessas duas instituições, quanto das construtoras, dos órgãos de licenciamento e outros órgãos da PMSP, tais como a Secretaria de Finanças. Esse monitoramento/ coordenação pela COHAB foi exercido por um assessor da presidência e pela CEF por um gerente subordinado ao Escritório de Negócios Sé, responsável pelas contas da Prefeitura.

O processo que antecedia a contratação da obra e se iniciava com a emissão do Atestado de Seleção pela COHAB envolvia:

1. Definição do valor dos terrenos, através da compatibilização dos valores resultantes das avaliações feitas, separadamente, pela COHAB-SP e pela CEF;

2. Elaboração do projeto por escritório contratado pela construtora selecionada;

3. Análise do projeto pela COHAB;

4. Análise, pela GIDUR (Gerência de Filial de Desenvolvimento Urbano), da FRE, do projeto, memoriais descritivos, orçamento (que deveria incluir o valor do terreno), cronograma da obra, diretrizes das concessionárias.

5. Aprovação do projeto pelos órgãos responsáveis: APROVI SEHAB e Corpo de Bombeiros, em todos os casos, e GRAPROHAB, em alguns 
dos casos em que o número de uh's era maior que 200 ou em que a área do lote era maior que $15.000 \mathrm{~m}^{2}$.

6. Análise jurídica pela CEF, das construtoras e da COHAB-SP, pela sua condição de vendedora dos terrenos.

Os longos prazos até a contratação resultaram de um conjunto de fatores:

- Dificuldade para a CEF e a COHAB-SP chegarem a um acordo sobre o valor dos terrenos.

- Demora da maioria das empresas para se mobilizar e iniciar o desenvolvimento dos projetos.

- Alterações dos valores adotados pela CEF como referência no programa, tanto o valor do $\mathrm{m} 2$ construído, quanto o valor do teto do programa.

- Indefinições de fluxo.

- Existência em algumas áreas da COHAB com ocupações irregulares.

- Vencimento do GERICc.

- Atraso nos pedidos de aprovação dos projetos, porque parte das empresas quis aguardar a aprovação de lei que concedeu isenção das taxas de aprovação.

- Necessidade da COHAB providenciar a regularização dos seus terrenos em relação ao recolhimento do IPTU. Foi preciso realizar o desdobro fiscal de muitos terrenos, que faziam parte do número de contribuinte de uma área maior; promover o reconhecimento como área urbana de muitos terrenos inscritos como terras rurais; e solicitar a aprovação de uma lei para a remissão de dívidas de IPTU que haviam se acumulado.

Inicialmente, previa-se que a COHAB elaboraria os projetos, orçamentos, cronograma das obras e os encaminharia para a CEF. Com a aprovação da CEF para esse conjunto de documentos, a Companhia publicaria edital de licitação, do qual esses documentos seriam anexos e teriam que ser considerados nas propostas. Tal licitação seria julgada por menor preço. Pensava-se que, dessa forma, seriam obtidos os menores preços e a adoção dos projetos da COHAB. Mas, 
como os tempos necessários para a preparação desses documentos e para sua aprovação pela CEF estavam muito longos, e como o prazo de vigência do PAR terminaria em dezembro de 2002, optou-se por se realizar uma licitação a ser definida não por menor preço, mas por sorteio. Dessa forma, as empresas selecionadas, posteriormente, contratariam a elaboração dos projetos e os submeteriam à aprovação dos órgãos de licenciamento e da CEF.

Uma das questões que tiveram que ser enfrentadas era a do nível de exigência das normativas da CEF, que estabeleciam um conjunto de impedimentos que dificultavam o desenvolvimento do programa no Munciípio de São Paulo. A COHAB-SP propôs e obteve a aprovação pela CEF para adequações à realidade do MSP, de normas e critérios estabelecidos para o PAR tais como:

- aceitação de edifícios com elevadores,

- anuência para maior número de unidades em empreendimentos contíguos, que era fixado em 500 ;

- adequação dos valores limites do programa aos preços de terra e construção verificados na Cidade; etc.;

Dentro do programa, também coube à COHAB: a execução de obras de infra-estrutura em áreas em que ainda eram necessárias (Itaquera IV e Valo Velho II); a realização do trabalho social de forma a não onerar a planilha das construtoras; promover a regularização fundiária e fiscal dos terrenos, que foram alienados ao FAR, encaminhando para isso, inclusive, a aprovação de Projeto de Lei de Isenção e Remissão de Débitos de IPTU. E também efetuar a gestão do programa, realizando o acompanhamento e coordenação das atividades sob responsabilidade dos vários agentes envolvidos (projetistas, construtoras, etc.).

A SEHAB atuou na agilização dos procedimentos de aprovação dos projetos dos empreendimentos, no encaminhamento para aprovação dos Projetos de Lei de Isenção de ITBI, ISS, de Taxas de Aprovação de Projetos, etc., e nos entendimentos com associações conveniadas visando seu atendimento pelo PAR.

O PAR-COHAB, na modalidade "Construção", ao final de 2004, envolvia a construção de 4.135 unidades habitacionais, recursos da ordem de $R \$ 131,9$ milhões e áreas que totalizam 201 mil m2 e, na modalidade "Reforma", contava com 
152 uh's em obras (Edifício São Paulo, antigo Hotel São Paulo) e 375 uh's (Edifício São Vito) em fase avançada de viabilização, mobilizando recursos da ordem de $\mathrm{R} \$$ 17,1 milhões.

Os resultados do programa foram expressivos tanto numericamente, quanto pela complexidade e quantidade de questões que tiveram que ser equacionadas para que os contratos fossem assinados. A importância numérica fica evidente quando se considera que, até a parceria da CEF com a COHAB, haviam sido contratadas 2.822 uh's pelo PAR na Cidade de São Paulo.

A complexidade do programa decorreu do grande número de empreendimentos (44 contratos de construção assinados até 2004, número igual ao de condomínios), do fato da assinatura de cada contrato ter que ser precedida do atendimento simultâneo a um grande número requisitos, tais como: inexistência de quaisquer pendências quanto à regularidade dos terrenos; ao licenciamento dos projetos; à situação jurídica e fiscal da COHAB, na condição de vendedora dos terrenos; à situação jurídica, fiscal, econômico-financeira e técnica das construtoras; e à necessidade de ajuste dos preços aos valores máximos por unidade habitacional e por $\mathrm{m}^{2}$ de área construída, num período (principalmente, até início de 2003), com consideráveis variações dos custos da construção, que motivaram duas elevações do teto de valor por moradia estabelecido para o Programa (de $R \$ 25.000$ para $R \$$ 28.000 e depois para $\mathrm{R} \$ 32.200)$.

Poucos dos projetos do PAR-COHAB-Construção ousaram além do prédio em forma de "H". Mesmo nas implantações as construtoras apresentaram projetos feitos sem muito esmero. Implantações que buscaram um adensamento extremo, pois, evidentemente, interessava às empresas construir o maior número de unidades possível. Em algumas delas, foram propostas geminações de prédios que criam um fosso para o qual ficam voltados compartimentos de permanência prolongada (salas, cozinhas ou dormitórios), o que ocasionaria um enorme prejuízo para a insolação e a ventilação desses compartimentos. Projetos desse tipo foram rejeitados na análise da $\mathrm{COH} A B$, o que significou uma melhoria em relação a tipologias que, anteriormente, eram aceitas por ela. 
A experiência do PAR e as experiências dos Chamamentos Empresariais da COHAB e da CDHU demonstram que são muito improváveis inovações e melhorias de projeto em programas em que as construtoras são as responsáveis pela sua execução ou contratação. Se se pretender que hajam projetos inovadores, eles deverão ser elaborados pelo contratante e constar como elemento integrante da pasta de licitação.

Dos empreendimentos já contratados ou em viabilização no âmbito do PAR, os de maior complexidade e que exigiram ou estão exigindo maior grau de ousadia são os Edifícios São Paulo e São Vito, que também integram o Programa Morar no Centro.

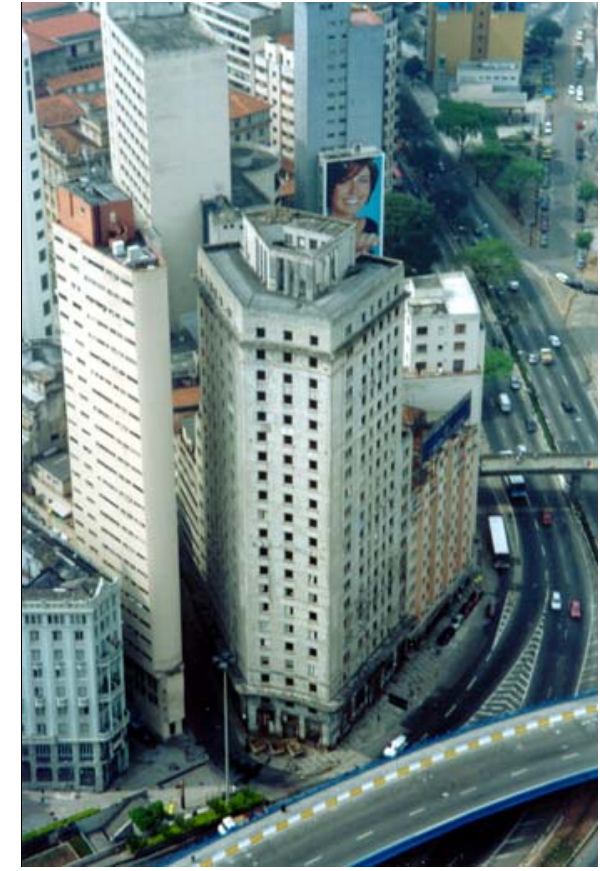

Edifício São Paulo - 152 uh's (foto de Robson Moreno)

O Edifício São Paulo, situado na Praça da Bandeira, esquina da Av. 23 de Maio com a Rua São Francisco, até meados dos anos 70 , foi sede do tradicional Hotel São Paulo, que, em seu período de glória, hospedou personagens importantes como Charles De Gaulle, ex-primeiro-ministro e expresidente francês. Depois, ficou abandonado por quase 30 anos, transformando-se numa parte deteriorada do Centro de São Paulo que precisava muito ser reabilitada. Em 21.10.2004, foi iniciada a obra de sua reforma, após a assinatura do contrato pela COHAB-SP, Caixa Econômica Federal (CEF) e Seta Construções (construtora). E concluída em outubro de 2006, com um ano de atraso em relação ao prazo inicial.

Com a reforma, o edifício do $4^{\circ}$ ao $21^{\circ}$ pavimento foi transformado em um conjunto residencial com 152 apartamentos (com 1 e 2 dormitórios e quitinetes). E, até o final a gestão Marta, havia o compromisso de transformar os espaços do térreo ao $3^{\circ}$ pavimento em um Centro de Educação Infantil e uma Unidade Básica de Saúde, cujas obras seriam contratadas pela COHAB, com recursos das Secretarias Municipais de Educação e Saúde. Com a sucessão de Marta Suplicy por José Serra, a reforma e adaptação para esses equipamentos de educação e saúde não tiveram 
prosseguimento, mas há informações de que a Prefeitura ainda pretende concretizálas.
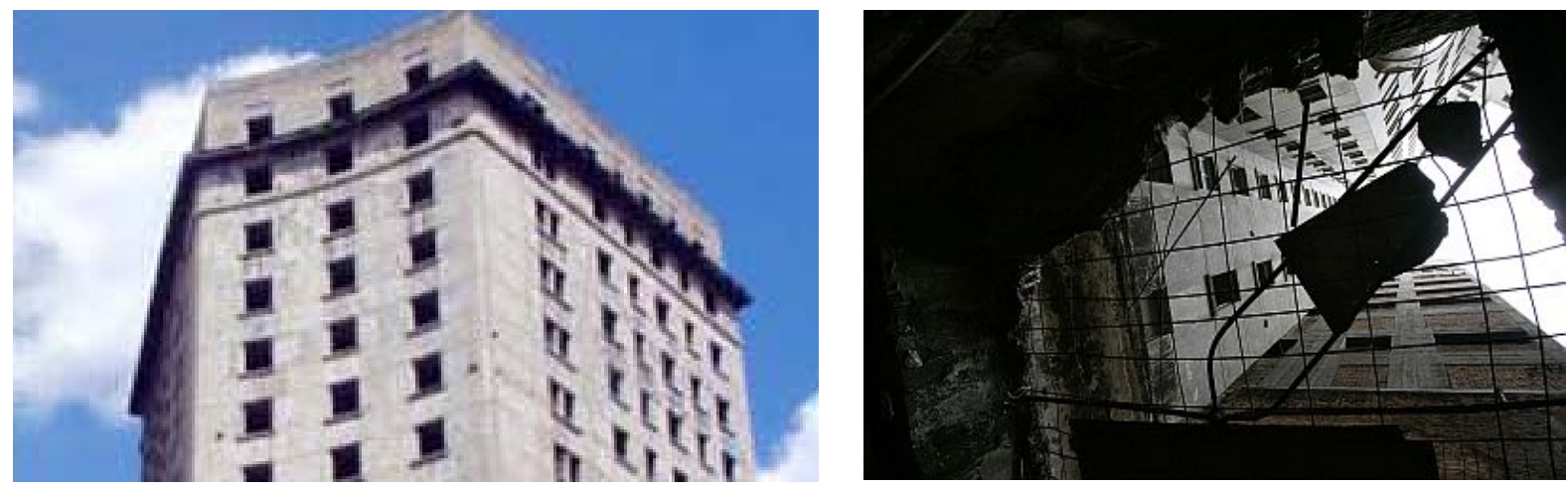

Edifício São Paulo - fotos anteriores à reforma

O conjunto residencial e esses equipamentos públicos eram objeto de antigas reivindicações do Fórum de Cortiços, um dos movimentos por moradia que atua na área central e que, desde 1999, quando promoveu uma ocupação do prédio com 3.000 pessoas, fazia gestões para viabilizar a sua reforma e destinação para moradia. O esforço havia sido no sentido de viabilizar uma reforma pelo PAR, com a participação da PMSP apenas no licenciamento e não na promoção. Buscou-se a montagem de um empreendimento em que os proprietários do edifício o vendessem a preço compatível, que uma construtora se interessasse pela execução da obra, e que a CEF aprovasse o financiamento. A intervenção da Prefeitura, como copromotora, não era cogitada, inclusive porque não era de se esperar que, durante a administração Pitta, iniciativas desse tipo recebessem seu apoio. Mas esse esforço não foi bem sucedido, tendo esbarrado em obstáculos na concretização da venda do prédio.

Na gestão Marta, o movimento reivindicou que a SEHAB e a COHAB interviessem. Essa reivindicação foi acolhida, dentre outras coisas, pelo impacto que o abandono de um prédio com aquelas dimensões e localização representava para a região central (Praça da Bandeira e entrada do Vale do Anhangabaú). Muitas negociações foram tentadas visando a venda do prédio ao FAR, mas a única alternativa que se mostrou viável foi a desapropriação do prédio pela Prefeitura, com recursos do FMH e através de um decreto de interesse social (DIS). Para a concretização da desapropriação, foi fundamental que do valor de avaliação do prédio, fosse abatida a dívida relativa ao IPTU, dos antigos proprietários para com o Tesouro Municipal. 
A COHAB/FMH contratou o escritório de projetos Fábrica Urbana e gerenciou a elaboração e aprovação (junto à CEF e aos órgãos de licenciamento) do projeto da reforma, que foi de grande complexidade em função da adaptação de um hotel para um conjunto residencial.

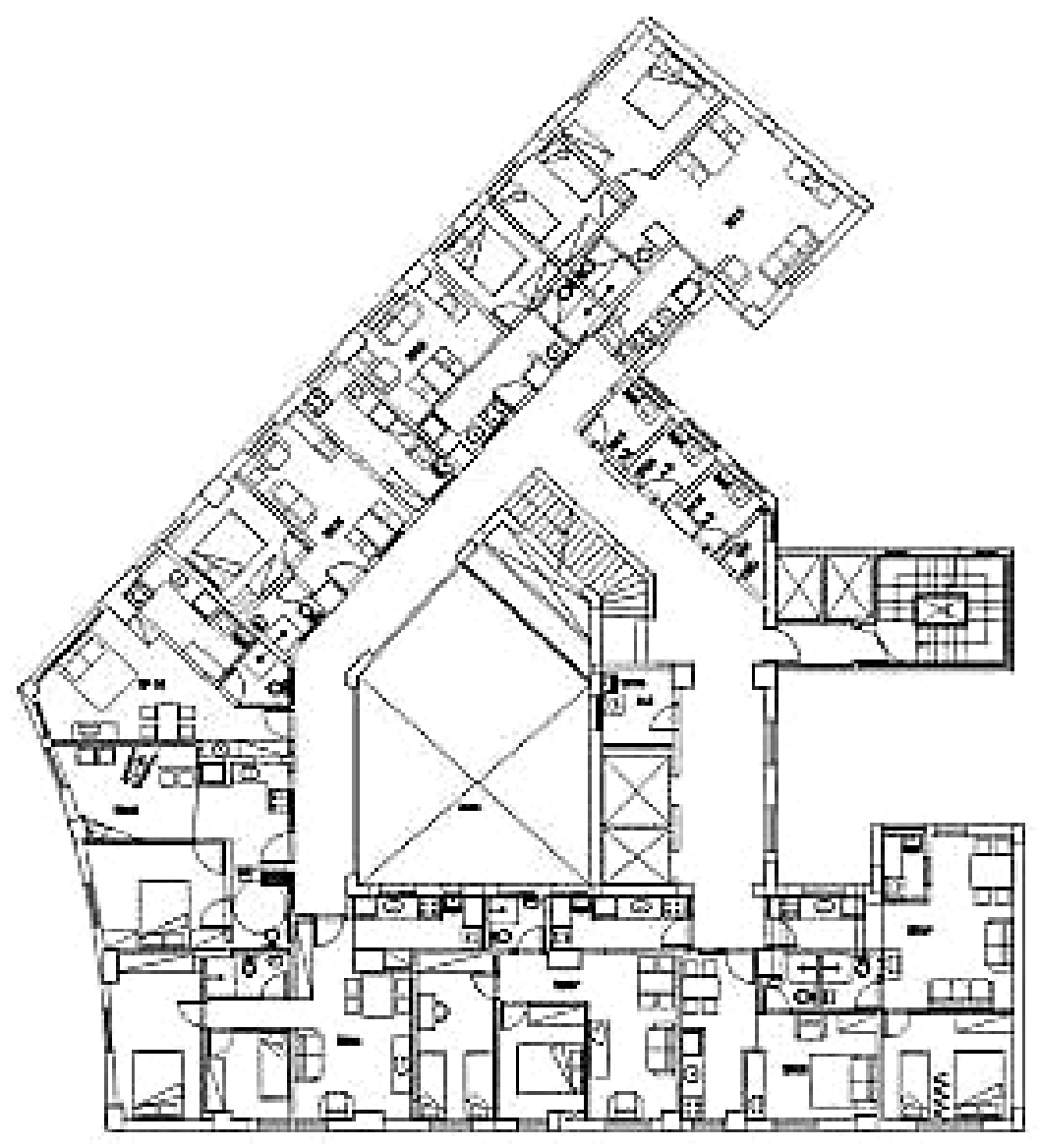

Edifício São Paulo -planta de um dos pavimentos-tipo e fotos após a reforma (fotos do autor)
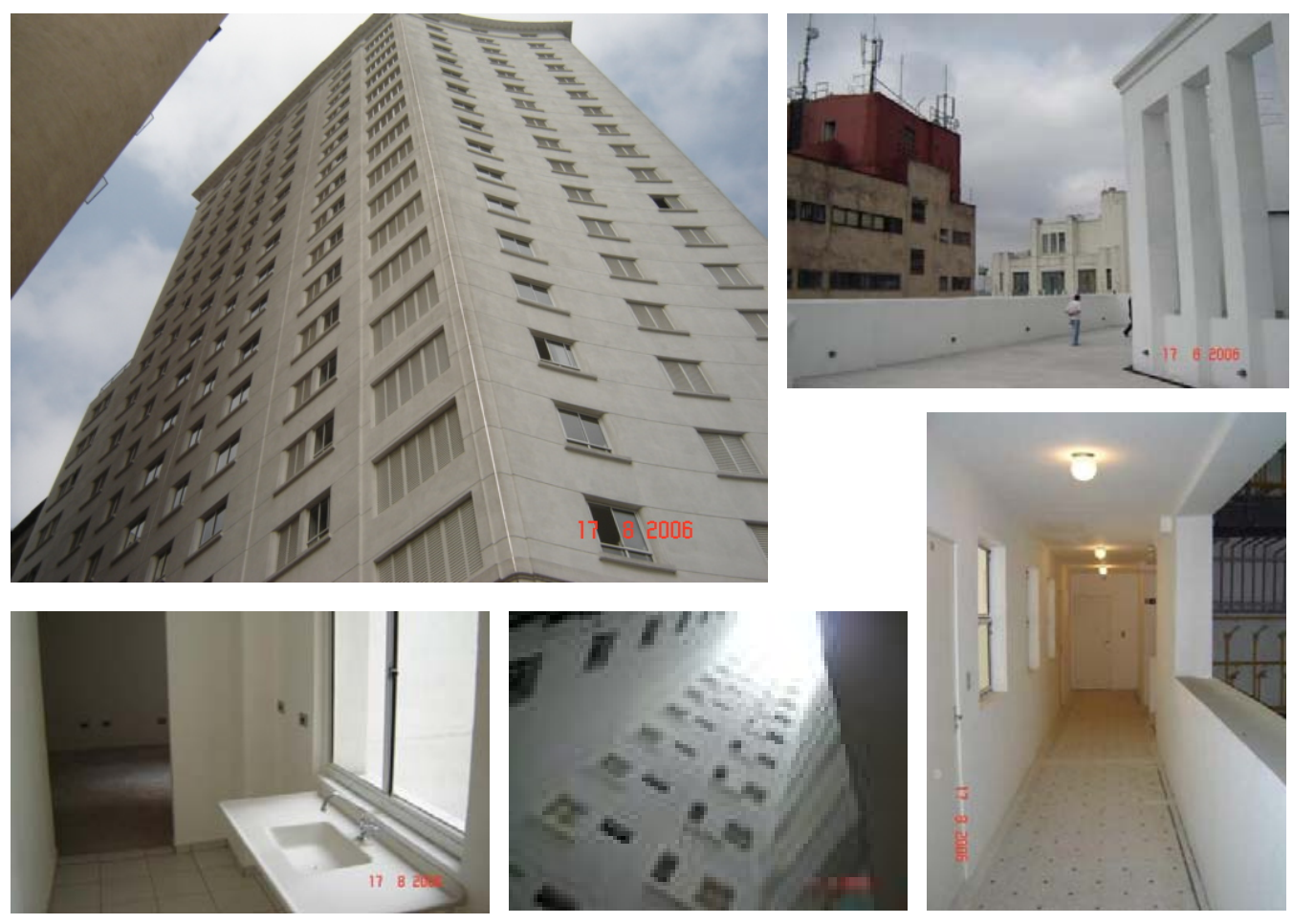
Tabela 5.11 - Hotel S. Paulo - Estudo sobre a viabilidade, áreas privativas, valores de aquisição e renda familiar necessária (R\$ de outubro /2004)

\begin{tabular}{|c|c|c|c|c|c|c|c|c|c|c|c|c|c|}
\hline \multirow{2}{*}{$\begin{array}{l}\text { UNI- } \\
\text { DA- } \\
\text { DE }\end{array}$} & \multirow{2}{*}{$\begin{array}{l}\text { TIPO- } \\
\text { LOGIA }\end{array}$} & \multirow{2}{*}{\begin{tabular}{c|}
$\mathbf{N}^{\circ}$ \\
$\mathbf{U H}$
\end{tabular}} & \multicolumn{2}{|c|}{ ÁREA PRIVATIVA } & \multicolumn{3}{|c|}{ VALOR (R\$) } & \multirow{2}{*}{$\begin{array}{c}\text { tx de } \\
\text { arrend. } \\
\text { a } 0,7 \%\end{array}$} & \multicolumn{2}{|c|}{$\begin{array}{c}\text { renda familiar } \\
\text { (R\$) }\end{array}$} & \multirow{2}{*}{$\begin{array}{c}\text { tx de } \\
\text { arrend. } \\
\text { a } 0,5 \%\end{array}$} & \multicolumn{2}{|c|}{$\begin{array}{c}\text { renda familiar } \\
\text { (R\$) }\end{array}$} \\
\hline & & & POR UH & $\begin{array}{c}\text { POR TIPO- } \\
\text { LOGIA }\end{array}$ & POR M2 & POR UH & $\begin{array}{c}\text { POR } \\
\text { TIPOLOGIA }\end{array}$ & & bruta & $n^{\circ} \mathrm{SM}$ & & bruta & $n^{\circ} \mathrm{SM}$ \\
\hline A & quitinete & 10 & 25,70 & 257,00 & 890,00 & $22.873,00$ & $228.730,00$ & 160,11 & 933,70 & 3,59 & 114,37 & 781,22 & 3,00 \\
\hline$B$ & quitinete & 9 & 25,90 & 233,10 & 890,00 & $23.051,00$ & $207.459,00$ & 161,36 & 937,86 & 3,61 & 115,26 & 784,18 & 3,02 \\
\hline $\mathrm{C}$ & 1 dorm. & 9 & 26,03 & 234,27 & 890,00 & $23.166,70$ & $208.500,30$ & 162,17 & 940,56 & 3,62 & 115,83 & 786,11 & 3,02 \\
\hline $\mathrm{D}$ & quitinete & 7 & 26,05 & 182,35 & 890,00 & $23.184,50$ & $162.291,50$ & 162,29 & 940,97 & 3,62 & 115,92 & 786,41 & 3,02 \\
\hline$E$ & 1 dorm. & 9 & 26,18 & 235,62 & 890,00 & $23.300,20$ & $209.701,80$ & 163,10 & 943,67 & 3,63 & 116,50 & 788,34 & 3,03 \\
\hline $\mathrm{F}$ & 1 dorm. & 9 & 27,24 & 245,16 & 890,00 & $24.243,60$ & $218.192,40$ & 169,71 & 965,68 & 3,71 & 121,22 & 804,06 & 3,09 \\
\hline G & 1 dorm. & 9 & 28,37 & 255,33 & 890,00 & $25.249,30$ & $227.243,70$ & 176,75 & 989,15 & 3,80 & 126,25 & 820,82 & 3,16 \\
\hline $\mathrm{H}$ & 1 dorm. & 9 & 29,48 & 265,32 & 890,00 & $26.237,20$ & $236.134,80$ & 183,66 & $1.012,20$ & 3,89 & 131,19 & 837,29 & 3,22 \\
\hline $\mathrm{I}$ & 1 dorm. & 9 & 29,83 & 268,47 & 890,00 & $26.548,70$ & $238.938,30$ & 185,84 & $1.019,47$ & 3,92 & 132,74 & 842,48 & 3,24 \\
\hline $\mathrm{J}$ & 1 dorm. & 1 & 30,24 & 30,24 & 890,00 & $26.913,60$ & $26.913,60$ & 188,40 & $1.027,98$ & 3,95 & 134,57 & 848,56 & 3,26 \\
\hline $\mathrm{K}$ & 1 dorm. & 6 & 30,31 & 181,86 & 890,00 & $26.975,90$ & $161.855,40$ & 188,83 & $1.029,44$ & 3,96 & 134,88 & 849,60 & 3,27 \\
\hline $\mathrm{L}$ & 1 dorm. & 9 & 30,89 & 278,01 & 890,00 & $27.492,10$ & $247.428,90$ & 192,44 & $1.041,48$ & 4,01 & 137,46 & 858,20 & 3,30 \\
\hline$M$ & 1 dorm. & 7 & 31,95 & 223,65 & 890,00 & $28.435,50$ & $199.048,50$ & 199,05 & $1.063,50$ & 4,09 & 142,18 & 873,93 & 3,36 \\
\hline $\mathrm{N}$ & 1 dorm. & 9 & 34,40 & 309,60 & 890,00 & $30.616,00$ & $275.544,00$ & 214,31 & $1.114,37$ & 4,29 & & & \\
\hline $\mathrm{O}$ & 1 dorm. & 9 & 36,72 & 330,48 & 890,00 & $32.680,80$ & $294.127,20$ & 228,77 & $1.162,55$ & 4,47 & & & \\
\hline $\mathrm{P}$ & 2 dorms. & 11 & 40,86 & 449,46 & 890,00 & $35.000,00$ & $385.000,00$ & 245,00 & $1.216,67$ & 4,68 & & & \\
\hline Q & 2 dorms. & 11 & 44,38 & 488,18 & 890,00 & $35.000,00$ & $385.000,00$ & 245,00 & $1.216,67$ & 4,68 & & & \\
\hline $\mathrm{R}$ & 2 dorms. & 9 & 49,81 & 448,29 & 890,00 & $35.000,00$ & $315.000,00$ & 245,00 & $1.216,67$ & 4,68 & & & \\
\hline \multicolumn{2}{|c|}{ TOTAL } & 152 & & $4.916,39$ & & & $4.227 .109,40$ & & & & & & \\
\hline
\end{tabular}

Fonte: Elaborado pelo autor c/ dados do Arquivo COHAB

Visando criar matrículas separadas, de forma a permitir que as áreas residenciais pudessem ser transferidas para a propriedade do FAR (Fundo de Arrendamento Residencial) e que as áreas dos equipamentos públicos ficassem em propriedade do Município, foi realizada a incorporação da reforma, proposta pela COHAB e que se constituiu numa experiência inovadora, inclusive, para os cartórios, acostumados a incorporar construções novas, mas não reformas.

Muito trabalho houve, também, para ajustar o orçamento do empreendimento aos limites admitidos pelo Programa, com muitas avaliações, negociações, revisões de especificações e reduções de custos, do qual participaram COHAB, CEF, a projetista e a construtora, selecionadas em licitações realizadas pela COHAB. Mesmo com todos os ajustes, verificou-se a necessidade de se efetuar a doação do prédio, que foi aprovada pelo Conselho Municipal de Habitação (reunião de 07.07.2004), como um subsídio às famílias que serão atendidas, garantindo, assim, que esse empreendimento fosse executado em consonância com a proposta de reabilitação do Centro com inclusão social. Subsídios como esse, da esfera municipal em parcerias com o governo federal, tem ocorrido em outras grandes cidades brasileiras, revelando-se como um mecanismo importante para a habitação de interesse social e, particularmente, para o combate à degradação das áreas centrais. 


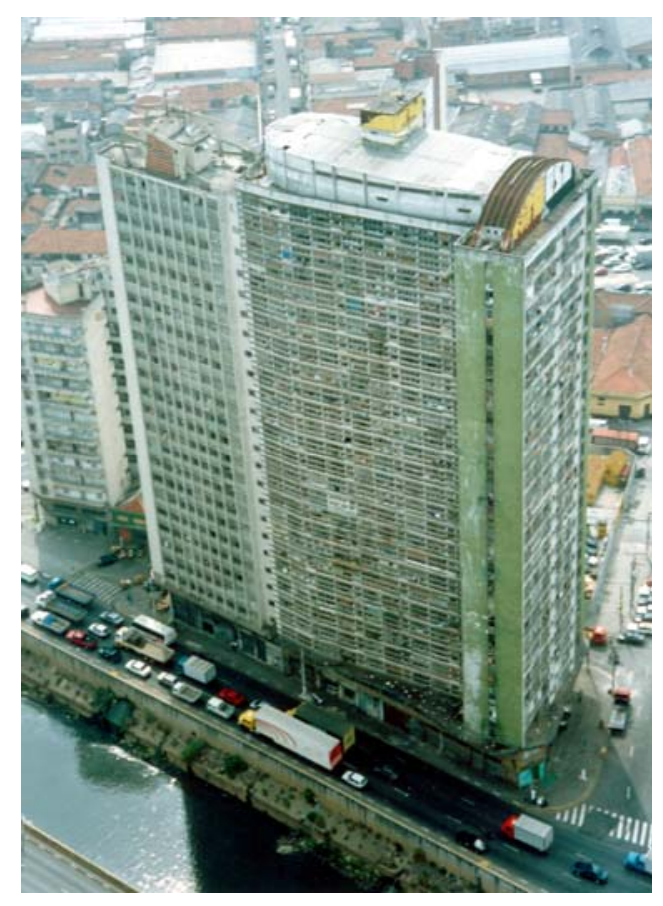

Edifício São Vito, que seria reformado (foto de Robson Moreno)

"O Edifício São Vito, o mais degradado dos grandes edifícios da Cidade e, por muitos, considerado o seu maior cortiço, foi um dos mais importantes empreendimentos que se tentou viabilizar dentro dos Programas PAR-COHAB e Morar no Centro. Localizado na Avenida do Estado, na região do Parque Dom Pedro II, está implantado em lote de $784,17 \mathrm{~m}^{2}$ e compreende 600 quitinetes, com área privativa entre 25 a $30 \mathrm{~m}^{2}$, distribuídas em 25 pavimentos-tipo, e 28 unidades comerciais no térreo e na sobreloja.

Inaugurado em 1.959, passou por um processo de grande deterioração, com seu condomínio acumulando grandes dívidas e uma taxa de inadimplência em torno de 70\%; e apresentando graves problemas em sua estrutura (necessidade de reforço), na circulação vertical (elevadores com funcionamento precário e escadas que não atendiam às exigências de segurança), nas instalações elétricas e hidráulicas (ligações irregulares, vazamentos, etc.), e fachadas em alto grau de deterioração, com brises corroídos, caixilhos de madeira quebrados e ausência de vidros em áreas consideráveis.

Nessas condições extremamente precárias de habitabilidade, encontravam-se, aproximadamente, 1.200 pessoas ou 510 famílias. Pesquisa realizada pela SEHAB em 2003 levantou o seguinte perfil dos moradores: 62\% tinham renda de até 3 salários mínimos; 41\% eram proprietários; 37\% residiam há menos de 1 ano no edifício; 48\% dos inquilinos pagavam entre $R \$ 50,00$ e $R \$ 150,00 ; 41 \%$ dos moradores tinham idade entre 30 e 65 anos; $59 \%$ das unidades abrigavam até 2 pessoas; 75\% dos moradores trabalhavam na região central da cidade.

O São Vito está sendo objeto de desapropriação movida pela COHAB, com recursos do $\mathrm{FMH}$, já tendo sido obtidas, até o momento, grande número de imissões na posse. A desocupação do edifício foi concluída em 2004, após um processo, marcado por muita negociação com as famílias, que, em sua grande maioria, foram atendidas pelo Programa Bolsa-Aluguel.

A decisão de requalificar o edifício por meio de reforma foi resultado de estudos que apontaram o alto custo social e financeiro da demolição. No caso de implosão, seria 
exigida a aquisição tanto do São Vito quanto do Edifício Mercúrio, com o qual está geminado, e uma provável interdição da Avenida do Estado. Uma demolição manual dos imóveis também seria dispendiosa e se estenderia por um período longo, estimado em 7 meses. Em ambos os casos, seria gerado um enorme volume de entulho a ser transportado para bota-fora, inevitavelmente, situado a grande distância. A demolição para construção de um novo edifício não seria interessante já que haveria uma significativa perda de potencial construtivo, em função das leis atuais serem mais restritivas. E a demolição sem nova construção significaria a necessidade de dar atendimento habitacional definitivo a, aproximadamente, 630 famílias de baixa renda (510 famílias do São Vito e 120 do Mercúrio) e significaria uma redução da oferta de moradia na região central (600 São Vito e 140 Mercúrio).

O projeto básico da reforma, elaborado por equipe coordenada pelos arquitetos Roberto Loeb e Luiz Capote, contratada pela COHAB/ FMH, estava sendo concluído ao final de 2004 e previa a transformação das 600 quitinetes em 375 apartamentos (175 apartamentos conjugados, 150 apartamentos de 1 dormitório e 50 apartamentos de 2 dormitórios), agrupadas em duas prumadas que se constituiriam praticamente em dois condomínios; além da implantação de uma creche, um restaurante-escola e um Telecentro. A proposta desses dois últimos equipamentos visava contribuir para a geração de emprego e renda, principalmente, para os moradores do edifício, mas também para a população de baixa renda da região.

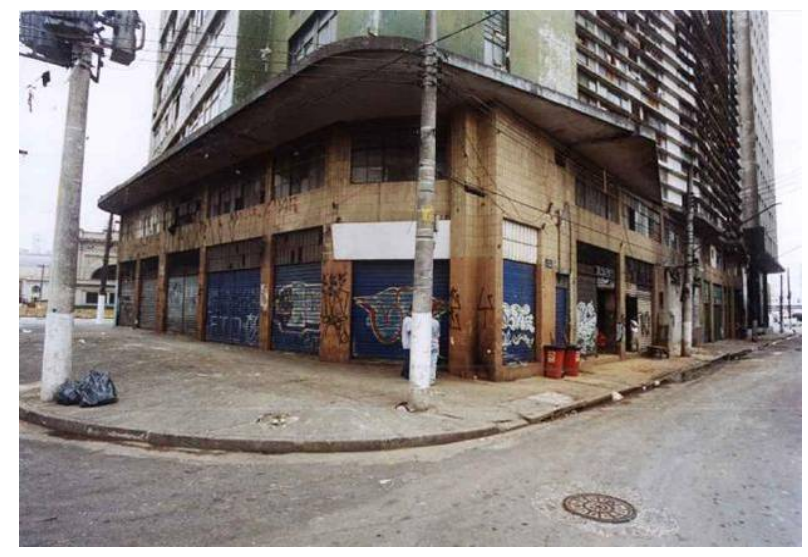

Edifício São Vito, situação em novembro/2004, semelhante à atual

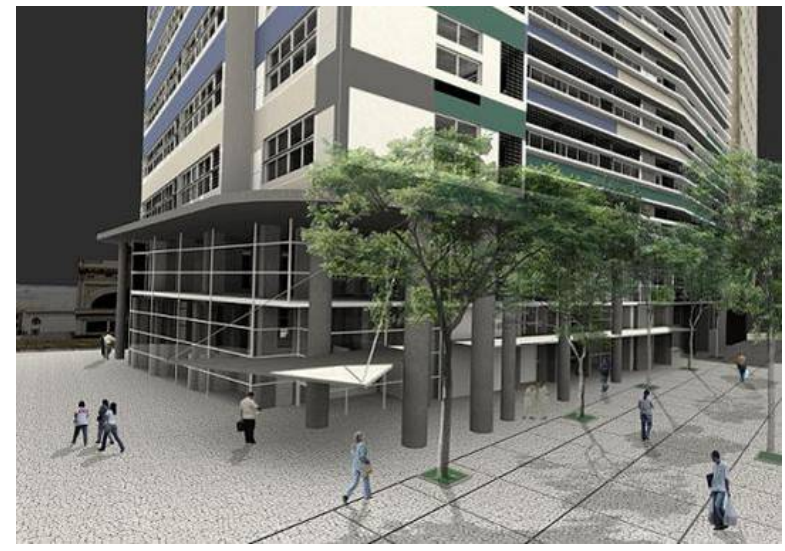

Edifício São Vito, conforme projeto de equipe coodenada pelos arquitetos Roberto Loeb e Luiz Capote

O financiamento da reabilitação do edifício foi desenhado e encaminhado, até dezembro de 2004, prevendo que a creche fosse implantada e operada com recursos da Secretaria Municipal da Educação; o Telecentro e o restaurante-escola implantados com recursos do FMH e operados, respectivamente, pelo Governo Eletrônico e pela 
Universidade Anhembi-Morumbi; e a reforma da área habitacional fosse financiada pelo Programa de Arrendamento Residencial (PAR), da Caixa Econômica Federal.

Por bastante tempo, a SEHAB e a COHAB desenvolveram trabalhos junto à $C E F$, objetivando viabilizar a reforma da parte residencial do São Vito pelo PAR. Em razão da especificidade, complexidade e por requerer medidas inovadoras, que, eventualmente, poderiam ser replicadas em outros empreendimentos, esses trabalhos envolveram também entendimentos com a alta direção da CEF e do Ministério das Cidades, além de todos os procedimentos usuais desse banco para análise da viabilidade de empreendimentos.

Ao final de 2004, havia uma anuência preliminar da CEF para o projeto; e estavam avançadas e próximas de serem objeto de consenso, as especificações de materiais e serviços e o orçamento da reforma. Também estava em processo de definição o valor máximo do empreendimento a ser admitido pela CEF, em função das estimativas de valor das unidades pós-reforma. Esse valor máximo e a soma dos preços previstos para a reforma estavam perto de convergirem, sobretudo, após a aprovação pelo Conselho Municipal de Habitação (reunião de 06.10.04) de doação do edifício, cujo valor de desapropriação é de $R \$ 4.690 .126,20$. Doação que se constituiria num subsídio às famílias a serem atendidas e se inscreveria entre as contrapartidas municipais, em programas habitacionais em parceria com o governo federal, que visam reabilitação de áreas centrais com inclusão social.

A necessidade da doação se verificou quando, após sucessivas avaliações feitas tanto pela CEF, quanto pela COHAB, e reuniões de negociação entre essas duas entidades, a CEF definiu que financiaria, no máximo, $R \$ 11.271 .127,50$ para o empreendimento residencial. Esse valor resultou da multiplicação do total das áreas privativas dos apartamentos $\left(14.267,25 \mathrm{~m}^{2}\right)$ pelo valor de $R \$ 790,00 / \mathrm{m}^{2}$ de área privativa, obtido na avaliação feita pela CEF do preço que os apartamentos a serem produzidos atingiriam no mercado.

O orçamento feito pelo escritório contratado pela COHAB/SP (Loeb/Capote), apontava um custo de reforma de $R \$ 11.561 .104,00$, valor esse ao qual deveria ser adicionado o estimado para o projeto executivo $(R \$ 170.000,00)$ e para a instituição do condomínio, averbação das unidades, seguro de execução de obra, etc. (R\$ 260.000,00). Dessa forma, o custo total da intervenção na área habitacional seria de $R \$ 11.991 .104,00$, exceto o custo do prédio (antes da reforma). Esse valor frente aos $R \$ 11.271 .127,50$ do financimento, não permitiria que o PAR efetuasse pagamento, nem ao menos parcial, pelo prédio, o que levou à aprovação da doação pelo $\mathrm{CMH}$. Além disso seria necessária uma 
redução dos custos de reforma de $R \$ 719.976,50$, que poderia ser atingida por um enxugamento ainda maior do orçamento da obra.

Ainda no intuito de viabilizar o empreendimento pelo PAR e de atender, no São Vito reformado, ao maior número possível de famílias que nele residiam, nos entendimentos com o Ministério das Cidades foi proposto que fosse: 1) estendida a empreendimentos de reforma em áreas de reabilitação, a possibilidade, restrita a prédios tombados, de transferência do edifício ao FAR, a partir apenas da imissão na posse; 2) aplicada a taxa de arrendamento de 0,5\%, para imóveis reformados destinados a famílias com renda igual ou inferior a 4 salários mínimos, desde de que o imóvel tivesse valor abaixo de $R \$ 28.500,00$ e área igual ou menor a $34 \mathrm{~m}^{2}$, taxa que estava restrita aos empreendimentos com construções novas; e 3) permitido que a média do valor das unidades pudesse atingir $R \$$ 35.000,00, que era adotado como máximo para cada unidade individualmente.

Essas três propostas foram aprovadas. No mesmo sentido, foi proposto à CEF que fosse considerada, na análise de risco das famílias pretendentes ao arrendamento, a utilização dos valores que obtivessem pela indenização relativa à desapropriação, mediante conta vinculada ao pagamento das taxas mensais de arrendamento. Essa proposta estava sendo avaliada.

Ao final de 2004, já se havia avançado muito na viabilização da reforma do São Vito, equacionando-se questões técnicas, sociais, legais e de financiamento de grande complexidade. Era razoável esperar que a reforma fosse concretizada, desde que, mantidas, na gestão seguinte, as mesmas diretrizes e o mesmo empenho.

Cabe lembrar que a parceria entre a SEHAB e a CEF para viabilizar o Programa de Arrendamento Residencial foi mais ampla do que a que é relatada aqui, envolvendo também um grande número de empreendimentos de promoção da iniciativa privada, em que a Secretaria desenvolveu o papel de indutora/facilitadora e de responsável pela indicação da demanda".(escrito por este autor p/ o "Relatório de Gestão 2001-2004") 
Tabela 5.12

Edif. São Vito - Estimativas de receitas e despesas (valores de final de 2004)

Receitas Estimadas

\begin{tabular}{|c|c|c|c|c|c|}
\hline \multicolumn{2}{|c|}{ tipologia } & área $\left(m^{2}\right)$ & $\begin{array}{l}\text { valor das uh's pela } \\
\text { avaliação CEF } \\
\text { (d) }\end{array}$ & $\begin{array}{c}\text { taxa de arrend.+ } \\
\text { cond.+ seguro } \\
\text { (função da coluna "d") } \\
\text { (e) }\end{array}$ & $\begin{array}{l}\text { renda familiar } \\
\text { necessária (função } \\
\text { da coluna "e") }\end{array}$ \\
\hline 2 dorms. & $3 \mathrm{~A}$ & 55,36 & $43.734,40$ & 461,50 & \multirow{9}{*}{ entre 5 e 6 SM } \\
\hline 2 dorms. & $6 \mathrm{~A}$ & 50,13 & $39.602,70$ & 428,86 & \\
\hline 1 dorm. & $4 \mathrm{~A}$ & 50,55 & $39.934,50$ & 431,48 & \\
\hline 1 dorm. & $5 B$ & 45,81 & $36.189,90$ & 401,90 & \\
\hline 1 dorm. & $7 \mathrm{~B}$ & 41,80 & $33.022,00$ & 376,87 & \\
\hline 1 dorm. & $3 B$ & 39,86 & $31.489,40$ & 364,77 & \\
\hline 1 dorm. & $1 B$ & 36,53 & $28.858,70$ & 343,98 & \\
\hline 1 dorm. & $8 \mathrm{~A}$ & 35,44 & $27.997,60$ & 337,18 & \\
\hline kit & $1 \mathrm{~A}$ & 38,42 & $30.351,80$ & 355,78 & \\
\hline kit & $2 \mathrm{~B}$ & 31,33 & $24.750,70$ & 311,53 & \multirow{6}{*}{ até 4,99 SM } \\
\hline kit & $6 \mathrm{~B}$ & 30,26 & $23.905,40$ & 304,85 & \\
\hline kit & $2 \mathrm{~A}$ & 29,98 & $23.684,20$ & 303,11 & \\
\hline kit & $4 \mathrm{~B}$ & 29,37 & $23.202,30$ & 299,30 & \\
\hline kit & $7 \mathrm{~A}$ & 29,31 & $23.154,90$ & 298,92 & \\
\hline kit & $5 A$ & 26,54 & $20.966,60$ & 281,64 & \\
\hline \multirow{3}{*}{ resumo } & total pav. tipo & 570,69 & $450.845,10$ & \multirow{3}{*}{ 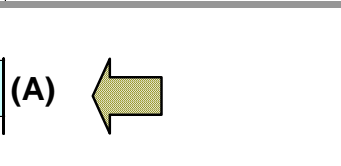 } & \\
\hline & total prédio & $14.267,25$ & $11.271 .127,50$ & & \\
\hline & média por apto. & 38,05 & $30.056,34$ & & \\
\hline
\end{tabular}

\footnotetext{
a) Avaliação da CEF $=\mathrm{R} \$ 790 /\left(\mathrm{m}^{2}\right.$ de área privativa $)$

b) Taxa de arrendamento igual $0,7 \%$ para valor de UH superior a $\mathrm{R} \$ 28.000$, e igual a $0,5 \%$ para valor inferior

Obs.:

c) Taxa de condomínio igual à do Riskalah Jorge $=R \$ 116,00$

d) $\mathrm{SM}=\mathrm{R} \$ 260,00$

e) Seguro de $0,09 \%$ do valor da UH, considerando arrendatário com idade entre 45 e 55 anos

f) Comprometimento de renda c/ habitação: $25 \%$, entre 4 e 5 SM, e 30\%, entre 5,1 e 6 SM

g) $73 \%$ das uh's c/ valor inferior a $\mathrm{R} \$ 35.000$
}

\section{Despesas Estimadas}

\begin{tabular}{|c|c|}
\hline projeto executivo: & $170.000,00$ \\
\hline obra de reforma: & $11.561 .104,00$ \\
\hline registros, seguros, etc: & $260.000,00$ \\
\hline total sem valor da desapropriação: & 11.991.104,00 \\
\hline desapropriação das áreas habitacionais: & $4.690 .126,20$ \\
\hline total geral: & $16.681 .230,20$ \\
\hline Retorno para o FMH (A-B) = & $(719.976,50)$ \\
\hline Subsídio do FMH (C-D) = & $5.410 .102,70$ \\
\hline Subsídio do FMH/ uh = & $14.426,94$ \\
\hline
\end{tabular}

Fonte: Elaborado pelo autor cl dados do Arquivo COHAB 


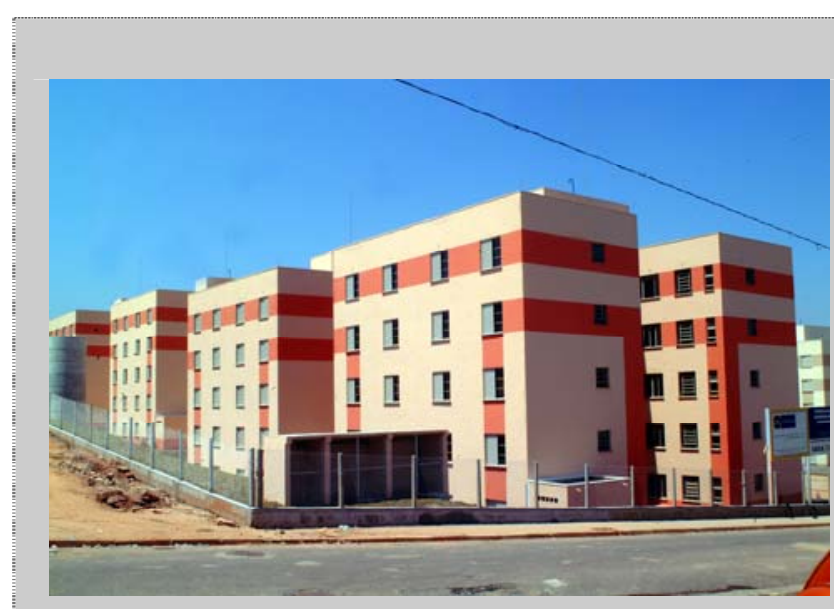

PAR - COHAB - CH Barro Branco II - 200 uhs (foto: arquivo COHAB)- Construção:. C.A.L

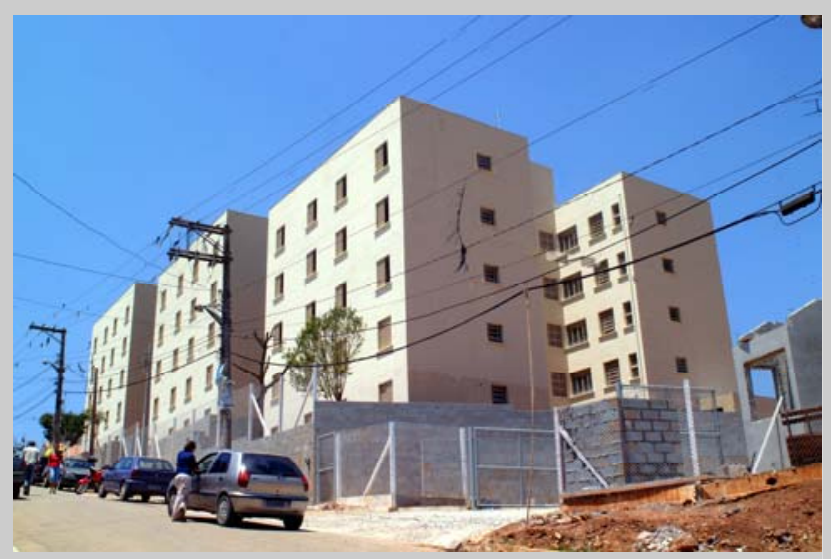

PAR - COHAB - CH Inácio Monteiro - 60 uhs (foto: arquivo $\mathrm{COHAB)}$ - Construção: Garden

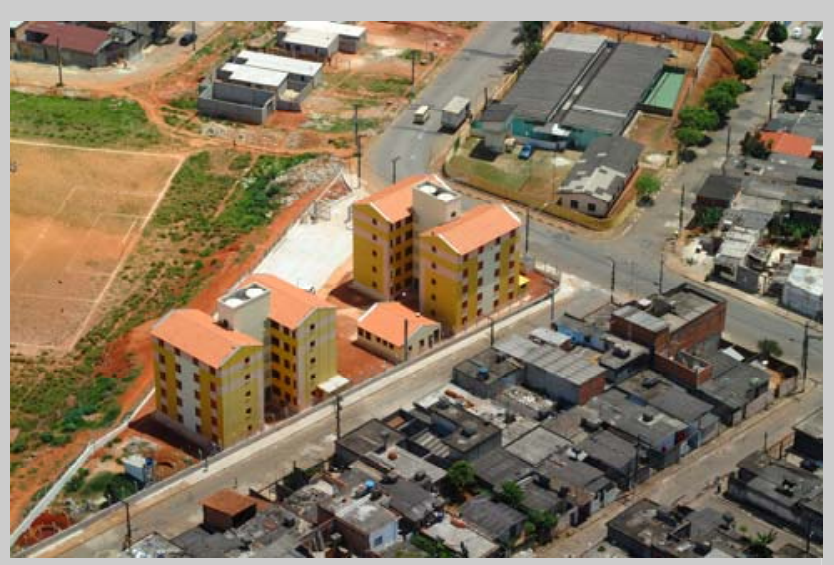

PAR - COHAB - CH Inácio Monteiro - 40 uhs (foto: arquivo $C O H A B)$ - Construção: MVG

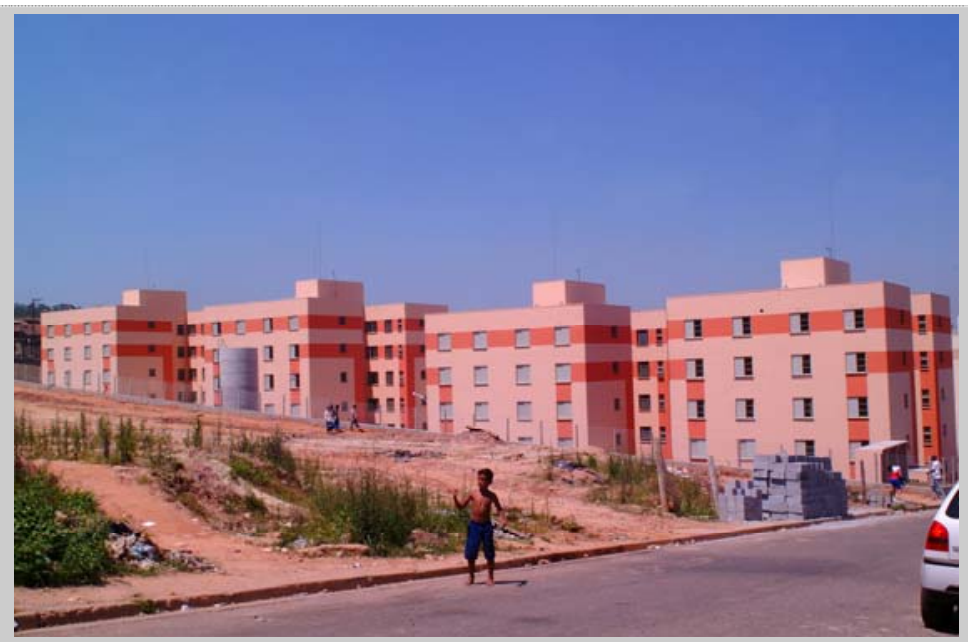

PAR - COHAB - CH Barro Branco II - 200 uhs (foto: arquivo COHAB) Construção: C.A.L

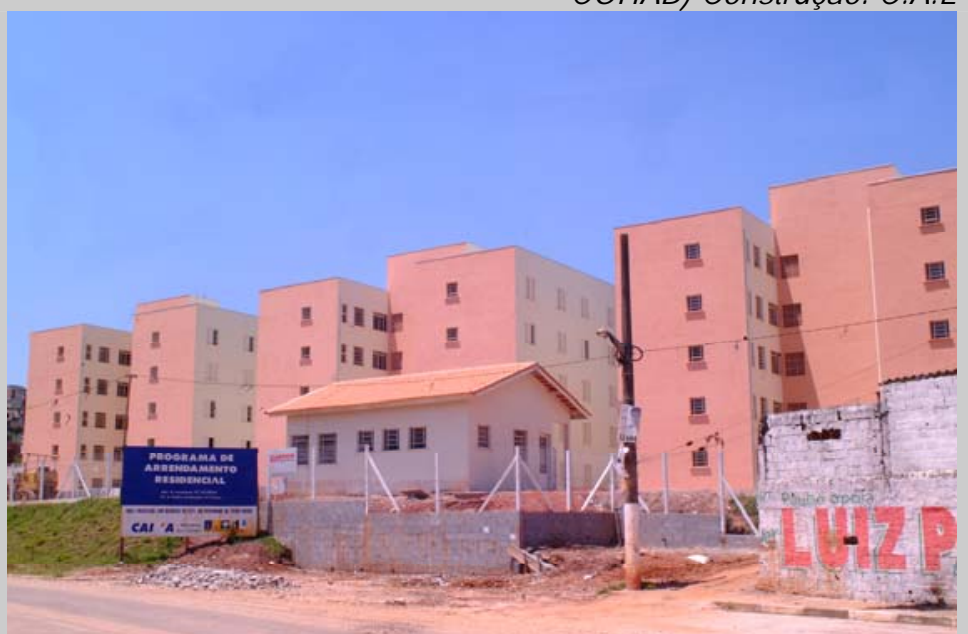

PAR - COHAB- CH Inácio Monteiro - 60 uhs (foto: arquivo COHAB) Construção: Garden

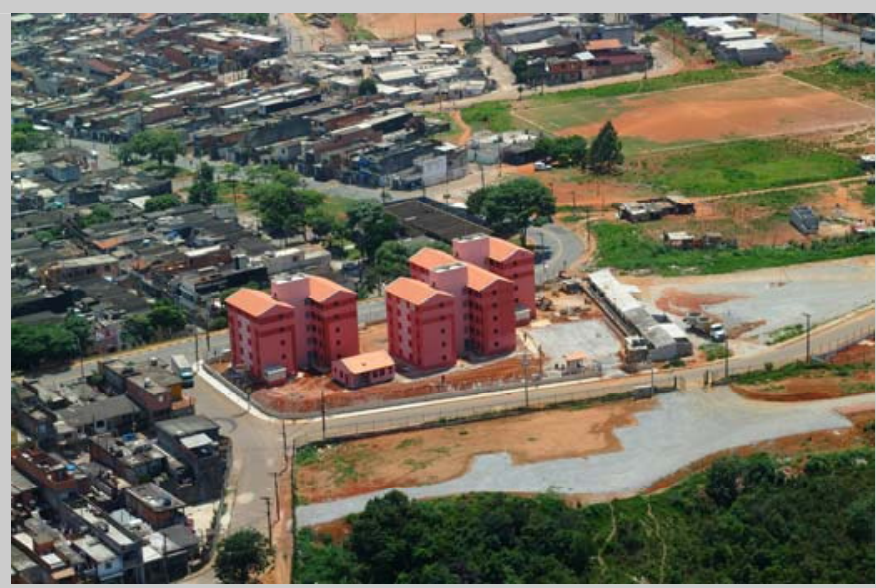

PAR - COHAB - CH Inácio Monteiro - 60 uhs (foto: arquivo COHAB) Construção: MVG 


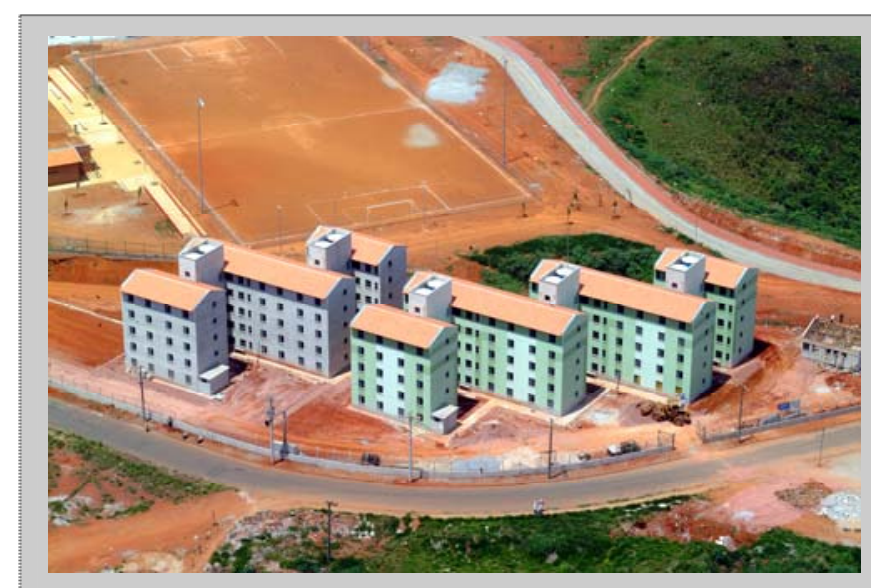

$P A R$ - COHAB - CH Inácio Monteiro - 100 uhs (foto: arquivo $(\mathrm{CH} A B)$ - Construção: $M V G$

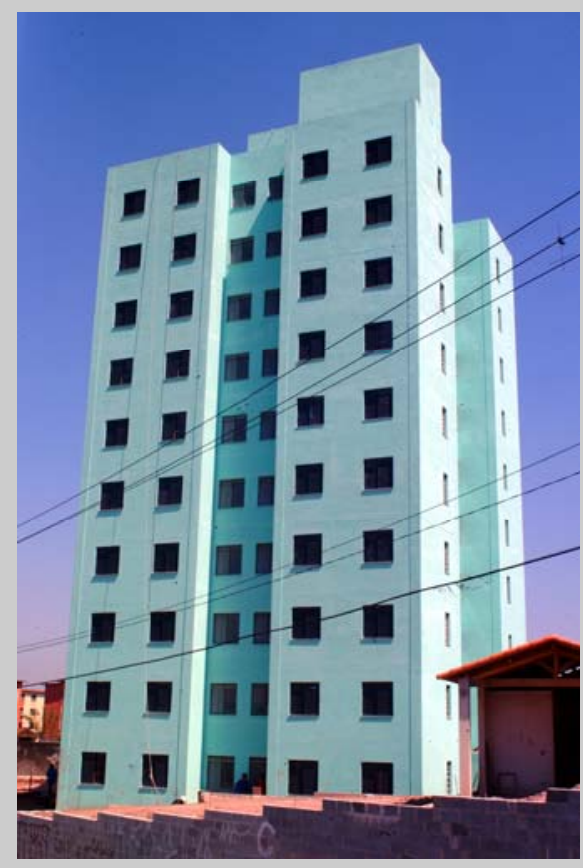

PAR - COHAB - Santa Etelvina VII - 40 uhs (foto: arquivo COHAB) - Construção: Delta

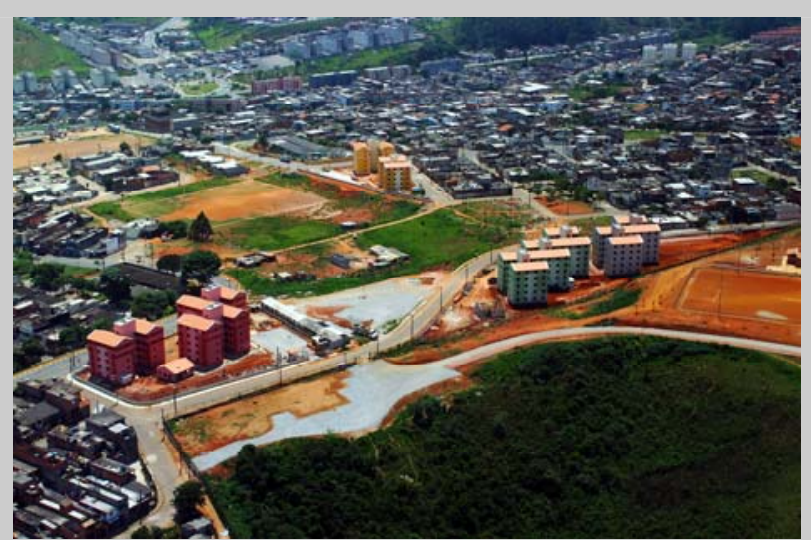

PAR - COHAB - CH Inácio Monteiro - 200 uhs (foto: arquivo COHAB) - Construção: MVG

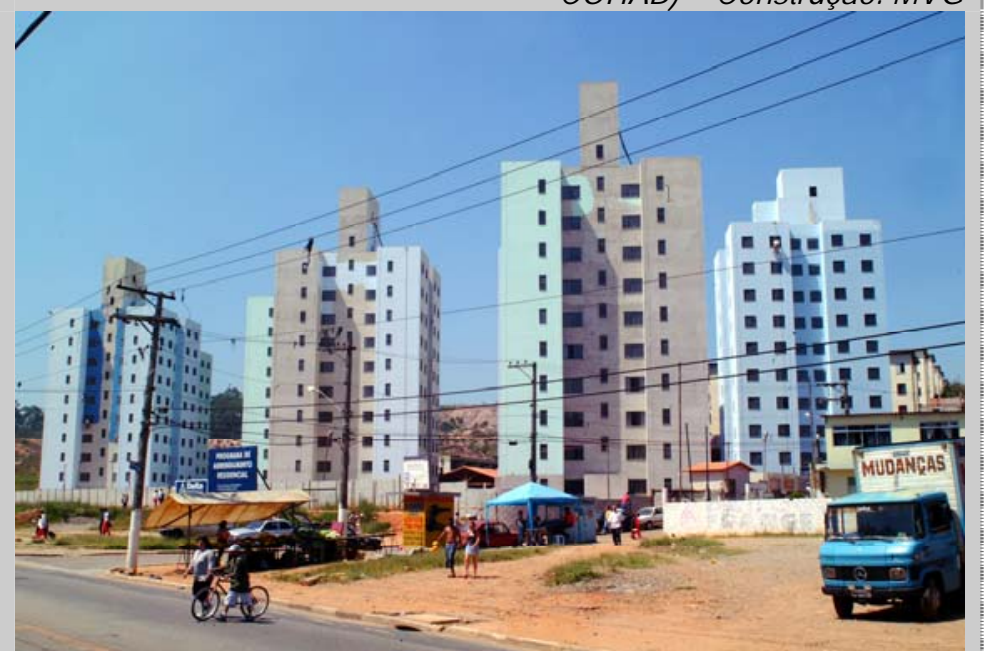

PAR - COHAB - Santa Etelvina li A - 280 uhs (foto: arquivo COHAB) - Construção: Delta

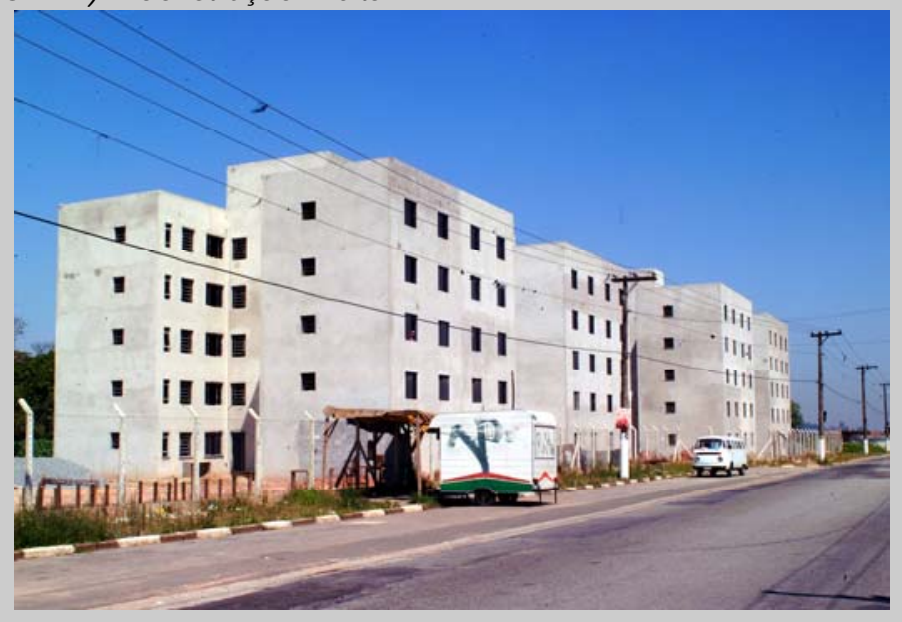

PAR - COHAB - Santa Etelvina I-IV A - 140 uhs (foto: arquivo COHAB) - Construção: Construmática 


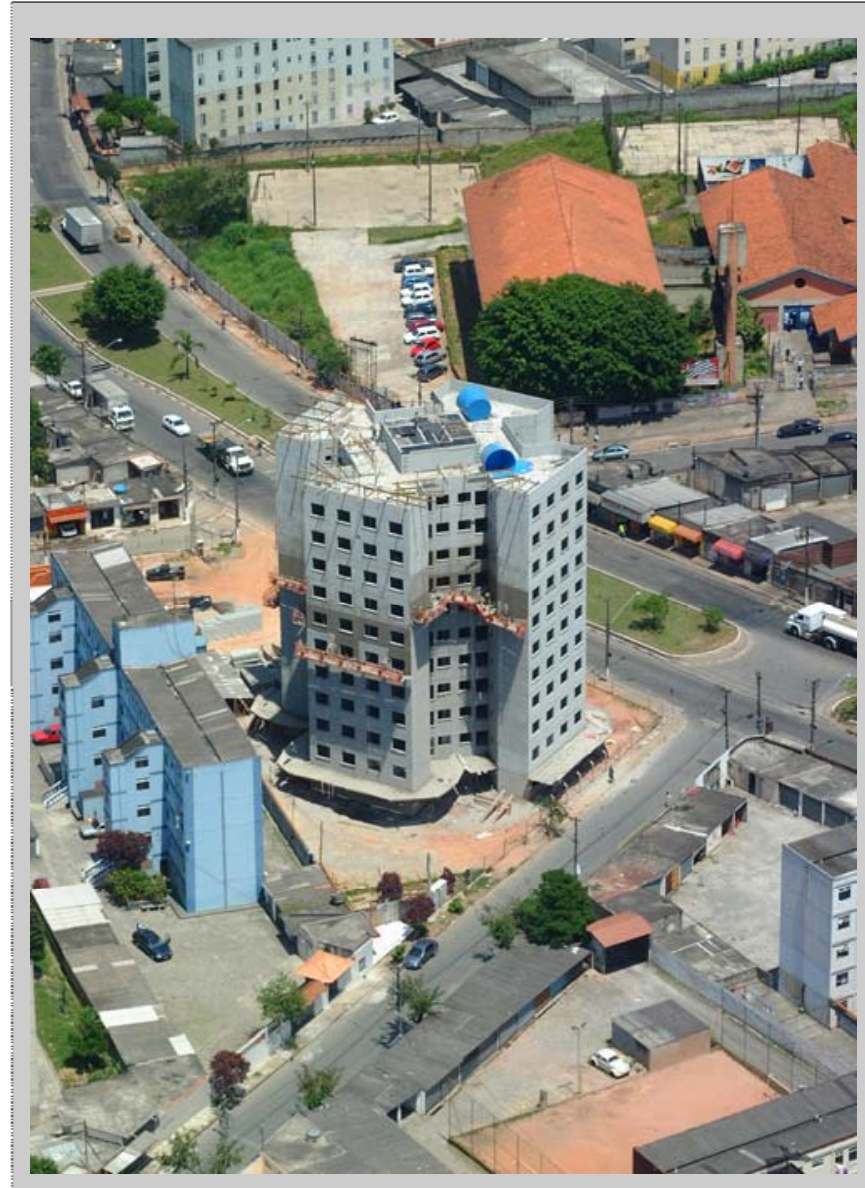

PAR - COHAB - José Bonifácio - 87 uhs (foto: arquivo COHAB) - Construção: Esteto

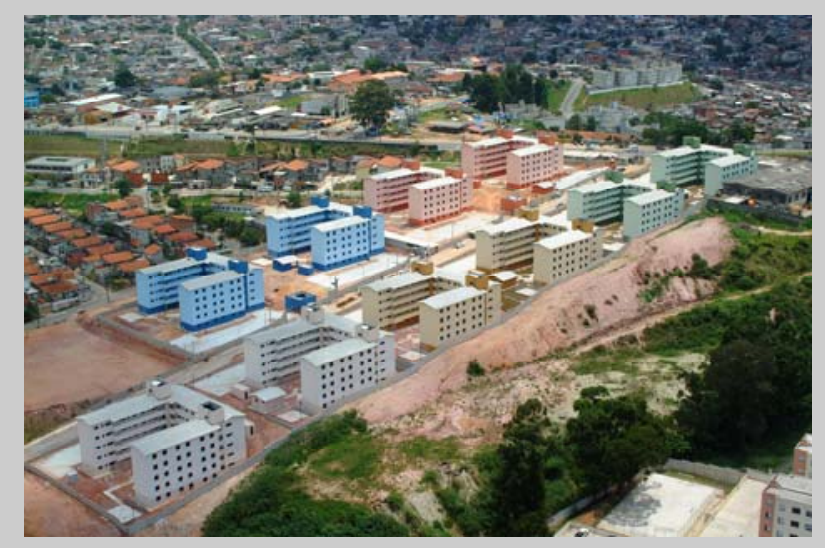

PAR - COHAB - Valo Velho II - 500 uhs (foto: arquivo COHAB) - Construção: HTR

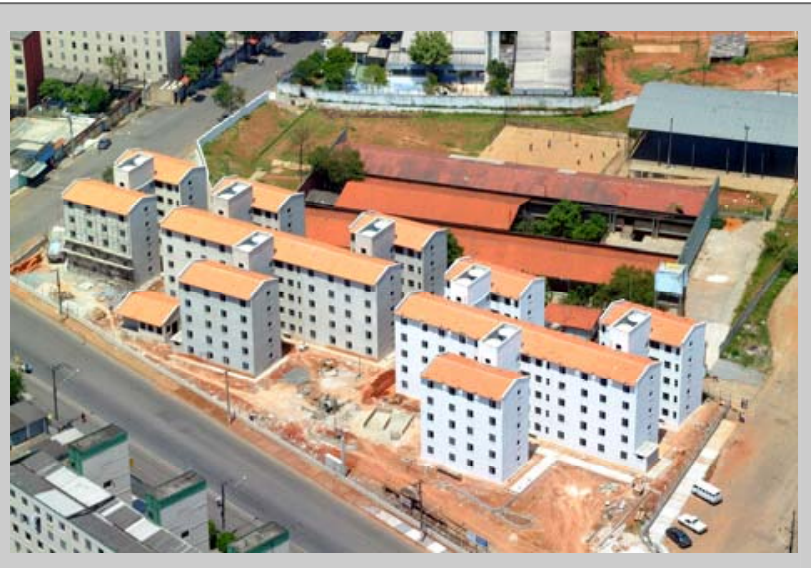

PAR - COHAB - José Bonifácio - 140 uhs (foto: arquivo COHAB) - Construção: MVG

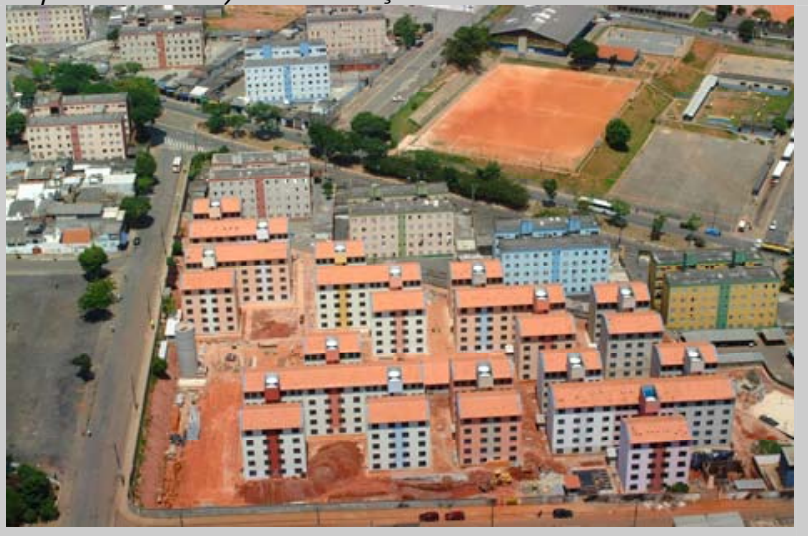

PAR - COHAB - José Bonifácio - 300 uhs (foto: arquivo COHAB) - Construção: Design

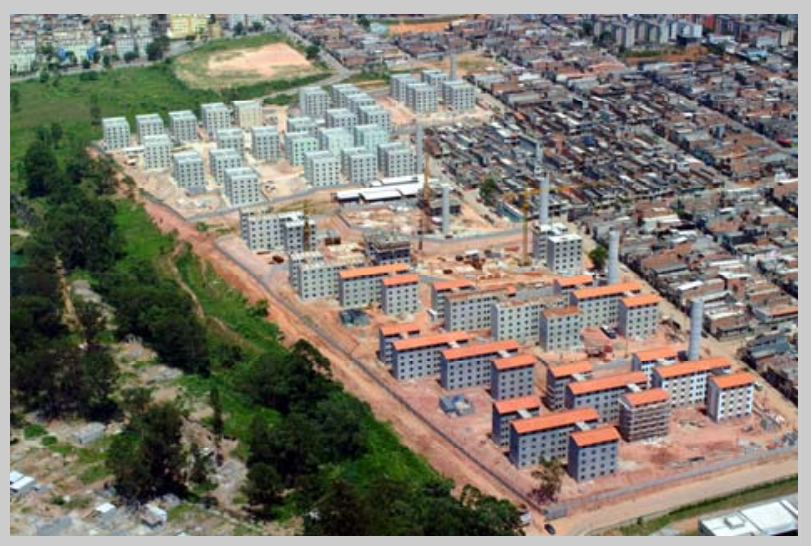

PAR - Itaquera IV -1100 uhs (foto: arquivo COHAB) Construção : Blokos e Sergus 


\subsection{O programa Morar no Centro}

Nos anos 80 e 90, a região central da cidade de São Paulo sofreu uma significativa perda de população e de atividade econômica. Entre 1980 e 2000, perdeu $30,35 \%$ de sua população, enquanto que a população da cidade, como um todo, crescia $22,52 \%$ e a população de alguns distritos mais periféricos e com infraestrutura urbana muito precária crescia muito mais, como a de Cidade Tiradentes, que cresceu 2114,98\%, Parelheiros, 2231,21\%, e Anhangüera, 619,66\% (AMARAL, 2002, p. 86).

No aspecto da perda de atividade econômica, verificou-se a transferência de muitas empresas para novos pólos de negócios (avenidas Paulista, Faria Lima, Luiz Carlos Berrini). Em 1996, conforme pesquisa citada por SILVA (2001, p. 7), $14,89 \%$ dos escritórios estavam vazios e 28 prédios comerciais estavam completamente desocupados e, em 2000, havia 25.000 unidades vazias, segundo Censo do IBGE (apud. SOMECK, in GASPAR, AKERMAN e GARIBE, 2006, p. 267). No entanto, a região central continuou ainda concentrando a maior oferta de empregos da cidade, pois nela existiam 1,99 empregos/morador, contra 0,47 em todo o município de São Paulo e 0,42 em toda a Região Metropolitana. E sendo destino da maioria das viagens diárias registradas na cidade, 19,61 milhões por dia, sendo que a "segunda região em destino de viagens, a sudeste, alcança a cifra de 4,1 milhões de viagens produzidas" (AMARAL, 2002, p. 90 e p. 83).

Um reflexo do esvaziamento da população residente é o número de domicílios vagos que, no centro, é $17,5 \%$ do total, sendo que na cidade de São Paulo é de 11,8\% (SILVA, 2001, p. 8).

Paradoxalmente, no centro, são numerosas as moradias precárias, sobretudo cortiços, e no início de 2001, existiam também 3 núcleos de favelas. Em 2004, uma delas, a do Gato, teve seus moradores transferidos para o conjunto residencial homônimo e foi demolida. O Plano Municipal de Habitação adotou dados que indicam a existência de 14.617 domicílios e 38.512 habitantes em cortiços.

A enorme precariedade da vida nos cortiços, abordada por KOHARA (1999), CARICARI e KOHARA (2006), BRANDÃO (2003), ao lado do grande número 
de imóveis vazios estimulou o surgimento e o fortalecimento de movimentos populares que reivindicavam moradia no centro, muitas vezes lançando mão da ocupação de prédios.

Por outro lado, o esvaziamento do centro provocou uma reação de entidades empresariais que formaram a Associação Viva o Centro. E a preocupação em garantir habitação social na área central motivou uma articulação de setores populares e técnicos que fundou o Fórum Centro Vivo, e iniciativas dos meios acadêmicos visando discutir propostas para a região, como foi o "Seminário: Habitação no Centro de São Paulo: Como Viabilizar Essa Idéia?", promovido pelo LABHAB, da FAUUSP, em 2000. A essas ações se somaram o início dos trabalhos do $\mathrm{PAC} / \mathrm{CDHU}^{74}$ e do $\mathrm{PAR} / \mathrm{CEF}^{75}$, visando promover empreendimentos de HIS no centro.

Esse conjunto de atores contribuiu para que, no programa de governo da candidata a prefeita Marta Suplicy, elaborado no Instituto Florestan Fernandes, fosse incluída uma proposta de desenvolvimento de um programa de moradia social nas áreas centrais e no anel intermediário, denominado Morar Perto. Esse programa previa:

[[......] requalificação de setores ou imóveis em áreas consolidadas, dotadas de satisfatória infra-estrutura, serviços e equipamentos urbanos, a fim de viabilizar a permanência de habitação para a população de baixa renda nessas áreas.

Além disso, o programa inclui também, a construção de conjuntos verticais em terrenos vazios ou através de adaptação e renovação dos edifícios com potencial a um melhor aproveitamento.

Busca-se a reaabilitação dos edifícios recuperando-os ou mesmo dotando-os de padrões satisfatórios de habitabilidade e segurança, tendo como conseqüência a necessária revisão da legislação vigente para a elaboração de novas estratégias de intervenção [......."

\footnotetext{
${ }^{74}$ Programa de Ação em Cortiços, da Companhia de Desenvolvimento Habitacional e Urbano do Estado de São Paulo.

${ }^{75}$ Programa de Arrendamento Residencial, da Caixa Econômica Federal.
} 
E era justificado da seguinte maneira:

"As intervenções públicas no campo da moradia têm reforçado a tendência de crescimento territorial da cidade, focando suas intervenções nas áreas periféricas da cidade, em conjuntos, via de regra, precários. O custo da terra é a principal causa deste modelo, característico das décadas de 70 e 80, que deixava de considerar a falta de infra-estrutura e os custos de deslocamento, em grande parte internalizados pela população moradora (gastando ou sofrendo).

O resultado deste tipo de intervenção foi a extensão inviável da cidade, a produção de padrões de segregação social no espaço onde a população de baixa renda ficou à margem da "cidade“, sem acesso aos seus benefícios. De maneira indireta, esse modelo acabou resultando na crescente formação de guetos e no aumento da violência nos bairros.

Paradoxalmente, há um crescente abandono de imóveis e terrenos ociosos em suas áreas consolidadas com boa infra-estrutura urbana. Em geral, estes setores apresentam ótima acessibilidade e equipamentos públicos, além de serviço e comércio variados, não só nos bairros centrais como também, nos centros regionais.

A moradia nas áreas centrais tem sido a mais antiga forma de opção para a população de baixa renda. Mesmo contando com edifícios insalubres e com altas densidades, esse tipo de habitação coletiva, permite ter rápido e fácil acesso ao local de trabalho e um melhor atendimento pelos equipamentos e serviços públicos, que são em geral de melhor qualidade."

Dentre as várias formas de intervenção que relacionava, previa a constituição de um parque de locação social, a assistência técnica e jurídica a grupos de famílias para viabilizar o acesso a financiamentos do FMH ou de outras fontes, e para a execução da reforma de prédios, e também a:

"criação e viabilização de mecanismos de participação da população envolvida em encontros, seminários e reuniões para a troca e exposição das experiências e para a discussão de conceitos que envolvam o meio ambiente urbano e o convívio em condomínios e vizinhança (deveres e limites)."

Cogitava como principais fontes de recursos: o PAR-CEF, o PAC-CDHU, operações urbanas e, evidentemente, o FMH.

A partir de 2001, o Morar Perto teve seu nome mudado para Morar no Centro, o que refletiu uma priorização das intervenções na área mais central. Mas 
foram mantidos os objetivos gerais que havia recebido no Instituto Florestan Fernandes, como um programa de habitação social que visava o atendimento de famílias de baixa renda em empreendimentos a serem implantados no centro e no centro expandido. E visava, também, contribuir para a recuperação de prédios e áreas deterioradas e para o "repovoamento" dessas áreas. Com o tempo, a esses objetivos iniciais foram agregados outros e melhor explicitados alguns que estavam subentendidos, tais como: buscar a diversidade social nos bairros centrais, conter o o processo de gentrificação. Ou seja, ficou mais clara a preocupação de que se deveria buscar evitar a "expulsão da população mais pobre, que muitas vezes resulta das políticas de reabilitação de áreas centrais", mas também "atrair segmento do mercado de média renda para residir no centro" (COHAB, Slides da "Apresentação aos Funcionários", 2004). Aparentemente contraditória, a idéia era de que, no centro, era desejável e havia potencial para se abrigar segmentos de baixa e média renda.

Ao longo da gestão, o Morar no Centro foi tomando um caráter de grande articulador das várias iniciativas, tanto do setor privado, quanto dos governos municipal e federal, e de coordenador das ações de vários setores da SEHAB, da COHAB e de outras secretarias municipais. Iniciativas e ações essas, evidentemente, relacionadas à habitação e à requalificação urbanística da área central e que envolveram:

1. Estímulo a empreendimentos do PAR de iniciativa de movimentos populares, em que a SEHAB colaborou realizando estudos de viabilidade, tomando medidas para a agilização do licenciamento e elaborando projetos de lei e fazendo gestões para que fossem aprovadas isenções de taxas e tributos municipais. E, em alguns casos, também articulando os proprietários do prédio, construtora e CEF, para viabilizar um empreendimento. Isso se deu, por exemplo, no empreendimento Joaquim Carlos, do PAR.

2. Discussões com a CEF sobre as exigências do PAR para a elaboração de projetos e formas de contratação de obras, buscando adequá-las às necessidades da Cidade de São Paulo, sobretudo de sua região central.

3. Execução do Programa de Intervenções em Cortiços com recursos do $\mathrm{FMH}$, que significou a continuidade de um subprograma da gestão 
Erundina, interrompido nas gestões Maluf e Pitta. Esse subprograma, basicamente, consistia na construção de pequenos prédios de apartamentos, em pequenos lotes onde tinham existido cortiços, para a venda financiada aos moradores desses cortiços.

4. Formulação de um novo programa de intervenções em cortiços cuja propriedade permaneceria privada.

5. Implantação, na Luz e no Glicério, dos dois primeiros Perímetros de Reabilitação Integrada do Habitat (PRIH's), que se constituíam em áreas delimitadas em que se visava a realização de trabalhos de levantamento de moradias precárias, de terrenos e prédios com potencial para empreendimentos de provisão habitacional, e de áreas que demandavam intervenções urbanísticas. Esses trabalhos e a coordenação das intervenções físicas que aconteceriam, posteriormente, seriam realizados pelos Escritórios Antena, a serem instalados em cada um dos perímetros. Dentre os previstos, ao final de 2004, haviam sido criados os escritórios da Luz e do Glicério.

6. Coordenação, no âmbito da SEHAB, dos esforços que visaram a obtenção de financiamento do BID para empreendimentos habitacionais na área central.

7. Entendimento com órgãos da administração pública municipal, estadual e federal, visando a cessão de áreas a serem destinadas a HIS. Esses entendimentos tiveram êxito no caso das áreas das Ruas das Olarias (SEMAB), da Assembléia e Cônego Vicente Marinho (SPTRANS). Mas haviam avançado bastante aqueles relativos à Ruas Vieira de Carvalho (SIURB) e Álvaro de Carvalho (SIURB), e da Av. 9 de Julho (INSS).

8. Organização do concurso nacional de projetos para os conjuntos habitacionais da Rua da Assembléia e da Rua Cônego Vicente Marino.

9. Levantamento de prédios com características que permitissem a reconversão para conjuntos de HIS. O que incluía a elaboração de estudos preliminares de projeto e de viabilidade, entendimentos e início de negociação com os proprietários. 
10. Entendimentos com os movimentos populares que atuam na área central.

Esse conjunto de tarefas foi dividido entre vários setores da estrutura da SEHAB, mas, principalmente, entre Procentro (Morar no Centro), HABI-Centro e COHAB. Inicialmente, sob coordenação do primeiro desses órgãos e, depois, sob coordenação da Assessoria do Secretário da Habitação. Internamente à COHAB, também, havia uma coordenação, exercida por um assessor da Presidência. Dessas tarefas, coube à COHAB:

a. Negociações para aquisição de prédios, mas que não se efetivaram, sendo que a que mais avançou, no entanto, sem se concretizar, foi a do prédio da Rua Assunção,

b. Desapropriação de prédios.

c. Providências para a desocupação dos prédios em desapropriação, inclusive, com a realização de trabalho social e concessão de bolsaaluguel.

d. Elaboração de projetos, geralmente, com o desenvolvimento interno à companhia dos estudos preliminares e com a contratação dos projetos básicos e executivos.

e. Contratação e fiscalização de empreiteiras e gerenciamento das obras.

Dos recursos alocados para o Morar no Centro, aqueles que atingiram maiores montantes foram os do FMH, BID, PAR e PEHP. A parceria com o BID será abordada mais adiante. A com o PAR foi tratada em capítulo anterior. Através do PEHP, Programa Especial de Habitação Popular, do Ministério das Cidades, criado pela Lei 10.840 , de 11/02/2004, e voltado para o atendimento de famílias de até 3 salários mínimos, foram obtidos $\mathrm{R} \$ 18,5$ milhões, que foram destinados a desapropriação e a reforma de prédios. 
Tabela 5.13 - Empreendimentos do Morar no Centro

\begin{tabular}{|c|c|c|c|c|c|c|c|c|}
\hline \multirow[b]{2}{*}{ Programa } & \multirow[b]{2}{*}{ Empreendimento } & \multirow[b]{2}{*}{ Distrito } & \multirow[b]{2}{*}{$\begin{array}{c}\text { Tipo de } \\
\text { intervenção }\end{array}$} & \multirow[b]{2}{*}{ Estágio em dez/04 } & \multicolumn{2}{|c|}{ No. de UH's } & \multirow[b]{2}{*}{$\begin{array}{l}\text { Fonte dos } \\
\text { recursos }\end{array}$} & \multirow{2}{*}{$\begin{array}{c}\text { Investi- } \\
\text { mento } \\
\text { (R\$) }\end{array}$} \\
\hline & & & & & $\begin{array}{c}\text { Concluí- } \\
\text { das }\end{array}$ & $\begin{array}{l}\text { Viabili- } \\
\text { zadas }\end{array}$ & & \\
\hline \multirow{7}{*}{$\begin{array}{l}\text { Intervenção em } \\
\text { Cortiços }\end{array}$} & Baronesa Porto Carrero & Bom Retiro & reforma & em obra & & 27 & FMH & nd \\
\hline & Casarão Rua do Carmo & Sé & construção & em obra & & 25 & FMH & nd \\
\hline & Eiras Garcia & Ipiranga & construção & obra concluída & 15 & 15 & FMH & nd \\
\hline & Imoroty & Ipiranga & construção & obra concluída & 8 & 8 & FMH & nd \\
\hline & Pedro Facchini & Ipiranga & construção & obra concluída & 12 & 12 & FMH & nd \\
\hline & Vilinha 25 de Janeiro & Bom Retiro & construção & obra concluída & 33 & 33 & FMH & nd \\
\hline & & & & $\begin{array}{r}\text { SubTotal } \\
\end{array}$ & 68 & 120 & & nd \\
\hline \multirow{15}{*}{ Locação Social } & Asdrúbal do Nascimento & República & reforma & em projeto/ desap. concluída & & 36 & PEHP & nd \\
\hline & Assembléia & República & construção & em projeto & & 160 & BID & nd \\
\hline & Belém - Metrô & Belém & construção & licitação de obra & & 200 & BID & nd \\
\hline & Bresser XIV & Brás & construção & licitação de obra & & 120 & BID & nd \\
\hline & Brigadeiro Tobias (Prestes Maia) & República & reforma & em projeto/ em desap. & & 250 & FMH & nd \\
\hline & Carlos Gomes & Sé & construção & em projeto & & 64 & FMH & nd \\
\hline & Cônego Vicente Marino & Santa Cecília & construção & em projeto & & 240 & FMH & nd \\
\hline & Olarias & Pari & construção & obra concluída & 137 & 137 & BID & nd \\
\hline & Residencial Parque do Gato & Bom Retiro & construção & obra concluída & 486 & 486 & BID & nd \\
\hline & Riachuelo & Sé & reforma & em projeto/ desap. concluída & & 132 & PEHP & nd \\
\hline & São Caetano & Bom Retiro & construção & preparação da licit. de projeto & & 100 & $\begin{array}{l}\text { FMH (reforma) e } \\
\text { PEHP (desap.) }\end{array}$ & nd \\
\hline & São João & Santa Cecília & reforma & em projeto/ em desap. & & 35 & $\begin{array}{l}\text { BID (reforma) e } \\
\text { FMH (desap.) }\end{array}$ & nd \\
\hline & Senador Feijó & Sé & reforma & em projeto/ desap. concluída & & 45 & PEHP & nd \\
\hline & Vila dos idosos (Pari 1) & Pari & reforma & obra iniciada em nov/04 & & 145 & PEHP & nd \\
\hline & & & & \begin{tabular}{|l|} 
Sub-total \\
\end{tabular} & 623 & 2.150 & & nd \\
\hline \multirow{6}{*}{$\begin{array}{c}\text { PAR - Promoção } \\
\text { Privada }\end{array}$} & Joaquim Carlos & Belém & reforma & obra concluída & 93 & 93 & PAR & 3.235 .060 \\
\hline & Labor & República & reforma & obra concluída & 84 & 84 & PAR & 2.216 .927 \\
\hline & Maria Paula & República & reforma & obra concluída & 75 & 75 & PAR & 1.990 .559 \\
\hline & Olga Benário Prestes & Belém & reforma & obra concluída & 84 & 84 & PAR & 1.806 .619 \\
\hline & Rizkallah Jorge & República & reforma & obra concluída & 167 & 167 & PAR & 4.119 .551 \\
\hline & & & & Sub-total & 503 & 503 & & 13.368 .716 \\
\hline \multirow{3}{*}{$\begin{array}{l}\text { PAR - Promoção } \\
\text { COHAB/FMH }\end{array}$} & $\begin{array}{l}\text { São Paulo (antigo Hotel S. } \\
\text { Paulo) }\end{array}$ & Sé & reforma & obra em andamento & & 152 & \begin{tabular}{|l|} 
PAR (reforma) e \\
FMH (desap.) \\
\end{tabular} & 4.322 .914 \\
\hline & São Vito & Sé & reforma & $\begin{array}{l}\text { projeto concluído/ trabalho } \\
\text { de aprov.na CEF }\end{array}$ & & 375 & \begin{tabular}{|l|}
$\begin{array}{l}\text { propunha-se: PAR } \\
\text { (reforma) e FMH } \\
\text { (desap.) }\end{array}$ \\
\end{tabular} & 12.430 .000 \\
\hline & & & & Sub-total & & 527 & & 16.752 .914 \\
\hline & & & & Total & 1.194 & 3.300 & & \\
\hline
\end{tabular}

Fonte: COHAB/SP, "Relatório de Gestão 2001-2004", 2004 
A Locação Social, inicialmente, foi pensada como um subprograma do Morar no Centro, mas depois adquiriu a condição de programa, pela sua importância e pela proposta de que sua área de abrangência não se restringisse àquela coberta pelo Morar no Centro. Por exemplo, propunha-se que alguns dos conjuntos que se pretendia construir na área da Operação Urbana Águas Espraiadas fossem destinados a locação social.

O Programa de Locação Social tem como objetivo viabilizar uma nova forma de acesso à moradia a famílias cuja renda não permitiria arcar com um financiamento para venda e compra. Nesse caso, a COHAB-SP com recursos do FMH e de financiamento externo (BID) construiria conjuntos que constituiriam um parque público de locação. Às famílias atendidas caberia o pagamento das despesas coletivas (ou condominiais) e do aluguel, que seria reduzido pela aplicação de subsídio, calculado em função da renda e do tamanho da família.

Programa semelhante a esse havia sido estudado e proposto por setores da CDHU. Inclusive, em 1992, a SEHAB e a COHAB-SP haviam integrado trabalho de cooperação técnica Brasil/França, coordenado por essa companhia estadual, que objetivava o desenvolvimento de um programa de locação social. Dentro das propostas que compunham esse trabalho, havia a de implantação pela $\mathrm{HABI} e$ COHAB de um conjunto habitacional na área denominada Brás XI, para a qual havia sido desenvolvido projeto escolhido através de um concurso nacional, realizado em 1989-1990 (COHAB, 1992, p. 42).

A parceria com o BID é um capítulo importante da implantação do Programa de Locação Social. A PMSP havia proposto a esse banco um financiamento para a requalificação do Centro, que previa intervenções nos sistemas viário, de drenagem e de iluminação, a renovação do Mercado Municipal, da Biblioteca Mário de Andrade e do Edifício Martinelli, a recuperação das praças da Sé, da República e Roosevelt, a implantação de um parque na foz do Tamanduateí, ao lado da Favela do Gato. A construção de um conjunto habitacional, para receber os moradores dessa favela, que seria erradicada, era uma das intervenções voltadas a habitação social propostas pela PMSP ao BID. 
Houve a concordância do banco quanto à inclusão dos empreendimentos de habitação, mas a discordância de que fizessem parte de um programa de locação social. Para superar essa discordância inicial, foram promovidos seminários e elaborados pareceres por consultores estrangeiros, visando um consenso que permitisse que o banco financiasse empreendimentos destinados a locação social.

Entre junho de 2004, quando foi assinado o contrato com o BID, e dezembro de 2004, quando terminou a gestão da Prefeita Marta Suplicy, foram incluídos, no financiamento, quatro projetos de locação social: Residencial do Gato, Olarias, Belém e Bresser. Além de dois projetos complementares à intervenção na Favela do Gato: parque e centro comercial. O valor total do contrato para todas as intervenções no centro (distritos Sé e República) é de US\$100.000.000, dos quais US\$ 19.019.460 seriam destinados a habitação de interesse social. E previa que, como componentes da exigida contrapartida nacional, seriam aceitos os investimentos feitos pela CEF/PAR, nos empreendimentos Celso Garcia, Riskallah Jorge, Maria Paula e Brigadeiro Tobias.

Dos projetos destinados à locação social, foram concluídos e entregues até o final de 2004, o Residencial Parque do Gato e o Conjunto Habitacional Olarias.

A permanência e adaptação das famílias à nova moradia, inclusive no que se refere à forma como arcam com as despesas dela decorrentes, e os efeitos sobre suas condições de vida, dentre os quais podem ser considerados os ganhos de sociabilidade, uma mudança no interesse e capacidade de participação e organização coletiva, são aspectos que deveriam ser observados, avaliados de forma sistemática em todos os empreendimentos de HIS (AMARAL, 2002, p. 97).

No caso dos empreendimentos do Programa de Locação Social, a observação desses aspectos é ainda mais relevante, pelo fato de se tratar de uma experiência inovadora e pelas condições da população atendida. Caracterizada pela baixíssima renda (até 3 salários mínimos), pela presença maciça de moradores de rua, favelas e cortiços, e pelo grande número de idosos, portadores de deficiências e mulheres desempenhando a função de chefes de família, é uma população altamente vulnerável, com grande dificuldade de acesso a postos de trabalho e a 
serviços públicos, e da qual seria de se esperar, também, dificuldades de adaptação à nova moradia.

Não tivemos acesso, apesar das tentativas, a alguns trabalhos realizados para a SEHAB/COHAB, por consultoria contratada, sobre o pós-ocupação dos dois empreendimentos mencionados, e esta pesquisa não pôde se estender e colher dados primários relativos à pós-ocupação. Dessa forma, os dados utilizados neste trabalho são basicamente fornecidos pelas APO's (avaliações de pós-ocupação) contidas na tese de Maurício VIEIRA (2005) e algumas informações de técnicos da COHAB-SP.

Várias das informações recebidas sobre o pós-ocupação dos dois empreendimentos (Resid. Pq. do Gato e Olarias) são preocupantes. Dos problemas apontados, poucos estão relacionados à qualidade do projeto e da construção, mas à adaptação e permanência das famílias, à inadimplência nos pagamentos, e à forte influência (ou controle, para alguns) de organizações criminosas.

Os resultados das pesquisas contidas na APO feita por VIEIRA (2005, p. 194-214), no Resid. Pq. Do Gato, indicam um bom nível de satisfação dos moradores quanto a características físicas do apartamento, considerado bom e ótimo por: $56 \%$ e $50,7 \%$, respectivamente, quanto ao número e tamanho dos quartos; $96 \%$ e $92 \%$ quanto ao número e tamanho dos banheiros; $96 \%, 86,7 \%, 60 \%$ e $68 \%$, respectivamente, à iluminação, ventilação, barulho e acabamentos. Por outro lado, $49,3 \%$ e $34,7 \%$ consideram ruins ou péssimo o tamanho de lavanderias e cozinhas. Na pesquisa espontânea, perguntados sobre o que mais gostavam no apartamento: $36 \%$ mencionaram a sala; $14,7 \%$, o quarto; $13,3 \%$, o banheiro.

Em relação aos espaços coletivos, o nível de satisfação é menor. Apesar de grande parte dos entrevistados ter considerado ótima ou boa a convivência com vizinhos (84\%), a aparência externa do conjunto (81,3\%), os equipamentos e áreas de lazer $(70,7 \%)$ e o silêncio após as 22 horas (54,6\%), verificou-se que um número considerável de moradores avaliava como ruim ou péssima a limpeza das escadas (56\%) e a organização do condomínio (42,7\%). Na pesquisa espontânea sobre os espaços coletivos, perguntados sobre "o que menos gostam no bloco e no conjunto", 
$24 \%$ responderam que da sujeira e 10,7\% que da falta de segurança, muita violência, etc.

Numa avaliação mais geral pelos moradores do Residencial Parque do Gato, em que foram dadas notas de 0 a 10, obteve-se como resultados: 8,0 para o apartamento, 7,7 para a localização do conjunto e 6,9 para o conjunto em si. Perguntados sobre as mudanças na vida em conseqüência da mudança do local de moradia, 65,3\% responderam que a vida melhorou, $20,0 \%$ que permaneceu igual e $14,7 \%$ que piorou.

A avaliação negativa quanto à limpeza, à organização condominial e à segurança, de certa forma, confirmam os relatos feitos por técnicos da COHAB-SP. Já a avaliação positiva da convivência com vizinhos e do silêncio após as 22 horas destoa da situação caótica (ou quase) desenhada por esses relatos. O que demandaria novas avaliações.

Ainda em relação ao Residencial Parque do Gato, é importante observar dados de abril de 2007, obtidos junto à COHAB relativos a inadimplência e a ocupações irregulares. A inadimplência atinge $64 \%$ e $68 \%$, respectivamente, no pagamento do aluguel $(R \$ 30,00)$ e da taxa de condomínio ( $R \$ 22,00)$. Já a irregularidade nas ocupações é verificada em 133 apartamentos (27,3\% do total).

Em relação a esses últimos aspectos, no Conjunto Habitacional Olarias, a inadimplência é de $55 \%$ e de $68 \%$, respectivamente, no pagamento do aluguel (R\$ $40,00)$ e da taxa de condomínio ( $R \$ 35,00)$. Já a irregularidade nas ocupações é verificada em 5 apartamentos $(3,6 \%$ do total). Sobre o Olarias não temos conhecimento de pesquisa semelhante à feita por VIEIRA no Parque do Gato. Entretanto, os depoimentos de técnicos da COHAB indicam uma situação complicada na gestão do condomínio, inclusive com a danificação de elevadores, e uma grande preocupação em relação ao risco de violência e ao tráfico de drogas. Quanto à preocupação com a violência e com o tráfico, ela teria também atingido moradores e trabalhadores e proprietários de estabelecimentos vizinhos, que passaram a condenar a construção do conjunto naquele local.

As informações recebidas sobre os dois empreendimentos já entregues, também, dão conta da interrupção do trabalho social que estava sendo realizado até 
o final de 2004, como uma conseqüência da mudança de governo e, dessa forma, das prioridades e diretrizes. O trabalho social que se fazia era mais intenso e buscava se orientar pelas metodologias mais adequadas.

Inclusive uma revisão dessa metodologia estava em curso, visando a formulação de um Plano de Trabalho Social específico para o Programa de Locação. Partia-se da experiência de HABI e COHAB e de documentos produzidos por esses órgãos sobre trabalho social, estavam sendo estudadas experiências semelhantes e bem sucedidas realizadas em cidades como Recife (Habitar Brasil), Rio de Janeiro (Favela Bairro) e Santo André (Programa de Urbanização Integral de Favelas). E para contribuir com essa formulação, haviam sido contratadas consultorias de várias instituições, dentre elas, o Instituto de Estudos Especiais (IEE), da PUC de São Paulo; o Consórcio Diagonal/ Villagua; a PBLM e a Terence Gallagher.

Dentre os principais objetivos que norteavam o trabalho que já se realizava, constavam:

- "Construir coletivamente o conjunto de regras de convivência do empreendimento;

- Orientar os moradores sobre o uso adequado das unidades locadas e espaços comuns;

- Orientar sobre gestão condominial;

- Orientar o processo de definição do sistema de informação e escolha de representante;

- Orientar sobre as funções e responsabilidades dos representantes condominiais eleitos (comissões e/ou síndico);

- Desenvolver ações sócio-educativas que coloquem em discussão a utilização de recursos e espaços coletivos, como o uso da água, energia elétrica, etc;

- Resgatar vínculos de socialização e estimular a criação de vínculos de solidariedade entre os moradores do empreendimento;

- Estimular processos que permitam aos moradores gerenciarem de forma autônoma seus orçamentos e as novas despesas advindas da locação;

- Articular o programa com outras iniciativas do poder público municipal;

- Buscar parcerias com órgãos federais, estaduais e organizações da sociedade civil para o desenvolvimento de projetos de geração de trabalho e renda, projetos culturais, de alfabetização, lazer, formação profissional, entre outros, de acordo com o perfil e necessidades identificadas junto aos 
moradores do empreendimento". (Programa de Locação Social - Plano de Trabalho Social, 2004)

O trabalho social que estava sendo realizado e, ao mesmo tempo, revisto, foi pensado para ser desenvolvido em três grandes etapas: a) conhecimento do território e da população a ser beneficiada, b) preparação e capacitação da população selecionada, e c) trabalho sócio-educativo do pós-ocupação.

Além disso, continha também uma proposta de contratação de uma ONG ou $\mathrm{OSCIP}^{76}$, com experiência em trabalhos com a população, para cuidar especificamente da gestão condominial. Gestão essa que, segundo técnicos da COHAB consultados, seria uma das grandes responsáveis pelo razoável sucesso do Condomínio República da Melhor Idade, da CDHU.

A interrupção do trabalho social nos moldes que vinha sendo realizado e a não substituição por nenhum outro tipo de trabalho com intensidade e qualidade equivalentes, evidentemente, tem que ser considerada como um dos principais fatores para o surgimento dos problemas citados, referentes à administração condominial, à "venda" informal de apartamentos, à má conservação (sujeira, etc.) de áreas de uso coletivo.

\footnotetext{
${ }^{76}$ Organização não Governamental - ONG e Organização da Sociedade Civil de Interesse Público -
} OSCIP. 


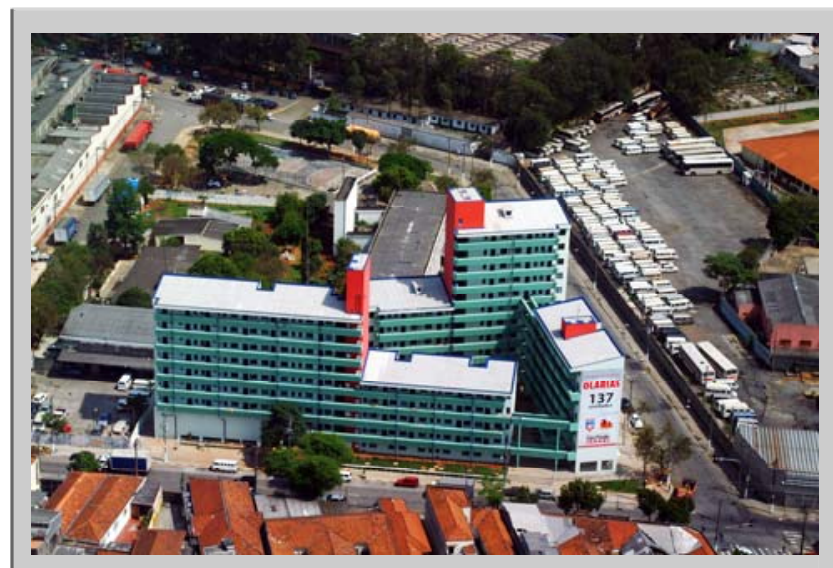

CH Olarias - vista aérea - (foto: Robson Martins) Projeto: Helena Saia Arquitetos Associados Arquitetura, Restauro e Planejamento slc Ltda.

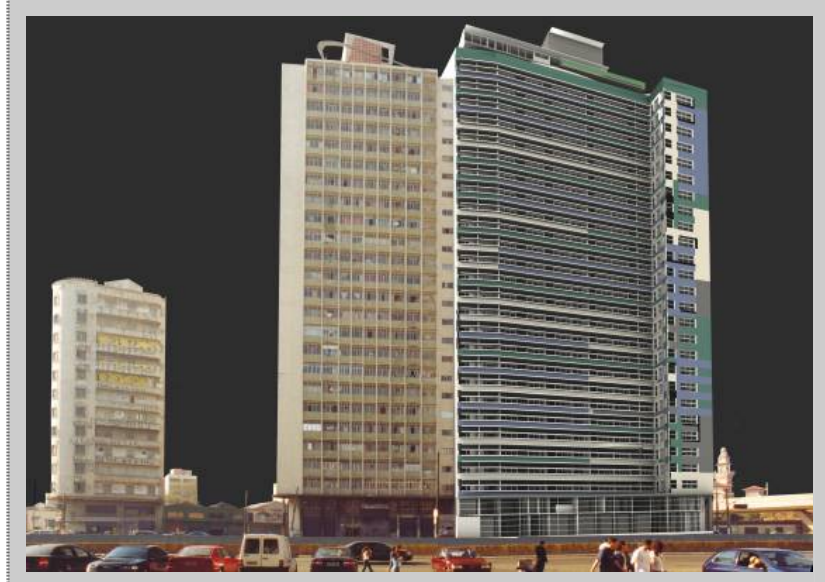

Edifício São Vito - vista - maquete eletrônica - (foto: arquivo COHAB) - Projeto - Lcapote Planejamento de Interiores e Objetos slc Ltda.

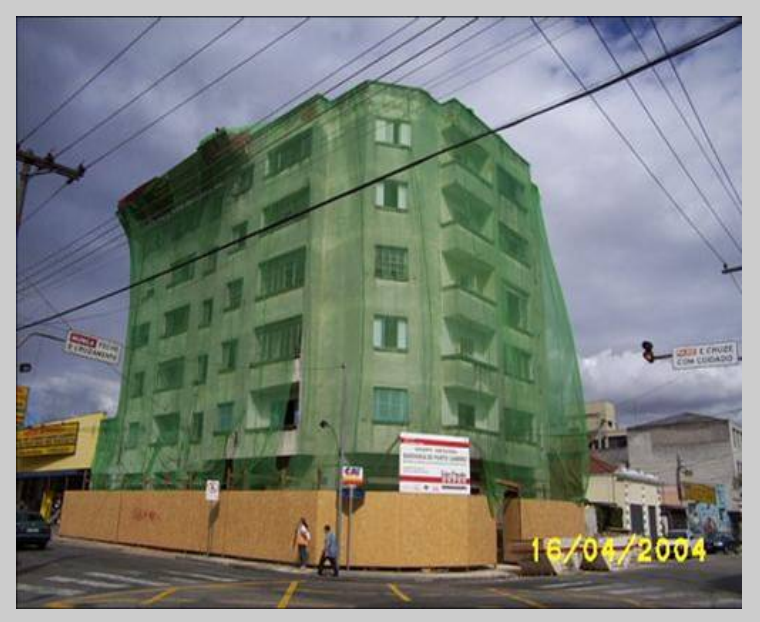

CH Baronesa de Porto Carreiro - início de obra - (foto: Robson Martins)- Projeto: Arqta. Maria Isabel Nobre de Sousa Cabral

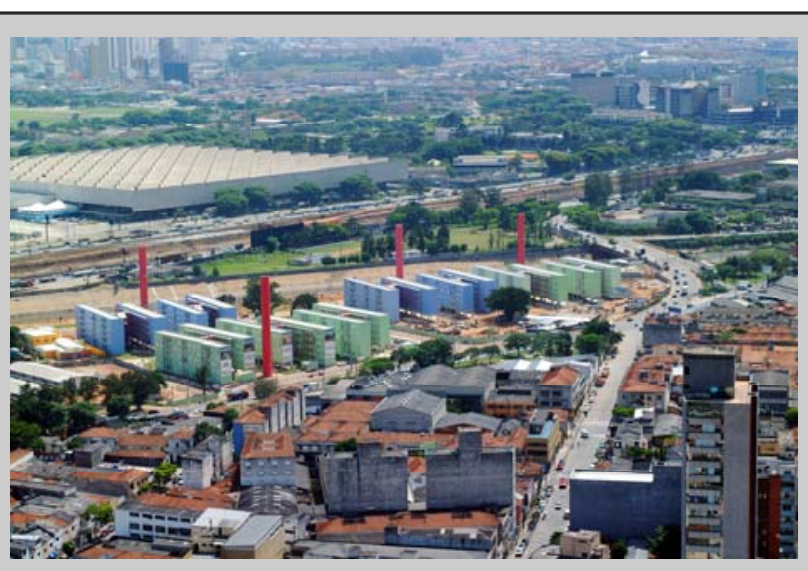

CH Parque do Gato - vista aérea - (foto: arquivo COHAB) - Projeto: concepção - Arqt.. Wagner Germano e Arqta. Tereza Herling e desenvolvimento Peabirú Trabalhos Comunitários e Ambientais

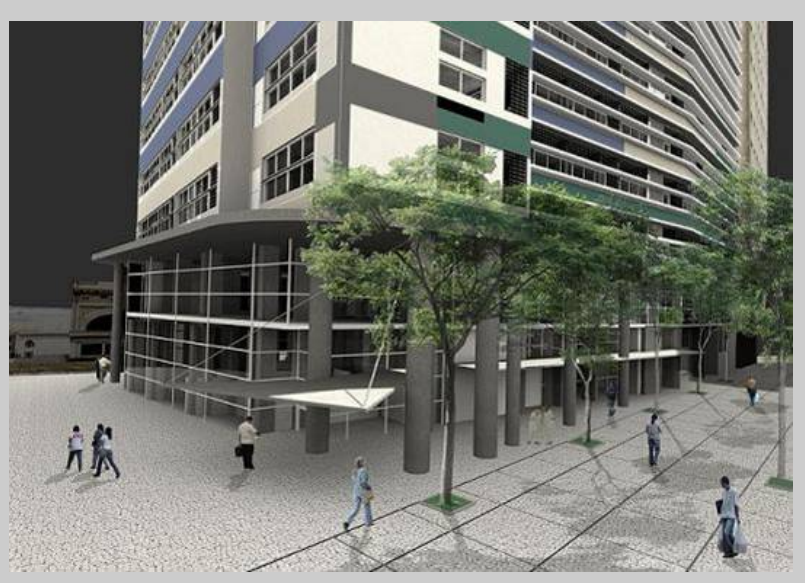

Edifício São Vito -unidades comerciais no térreo e sobreloja - maquete eletrônica - (foto: arquivo COHAB) Projeto - Lcapote Planejamento de Interiores e Objetos slc Ltda.

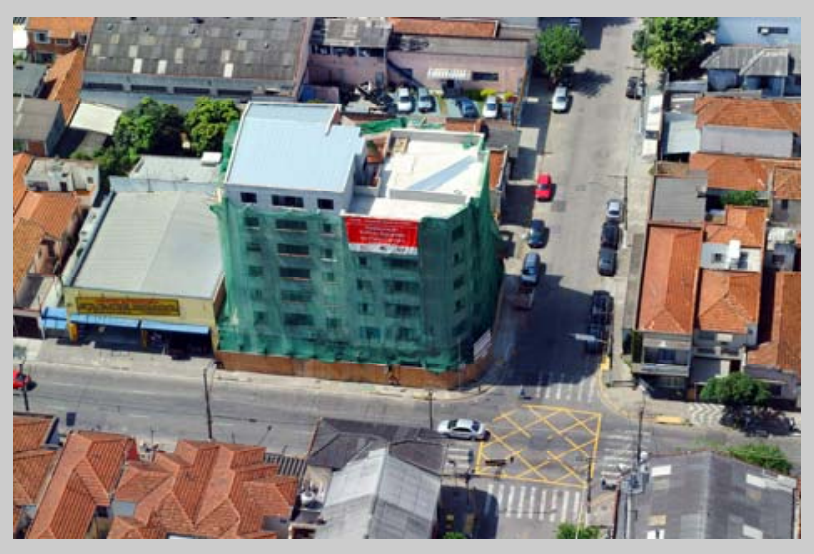

CH Baronesa de Porto Carreiro - vista aérea - (foto: Robson Martins)- Projeto: Arqta. Maria Isabel Nobre de Sousa Cabral 


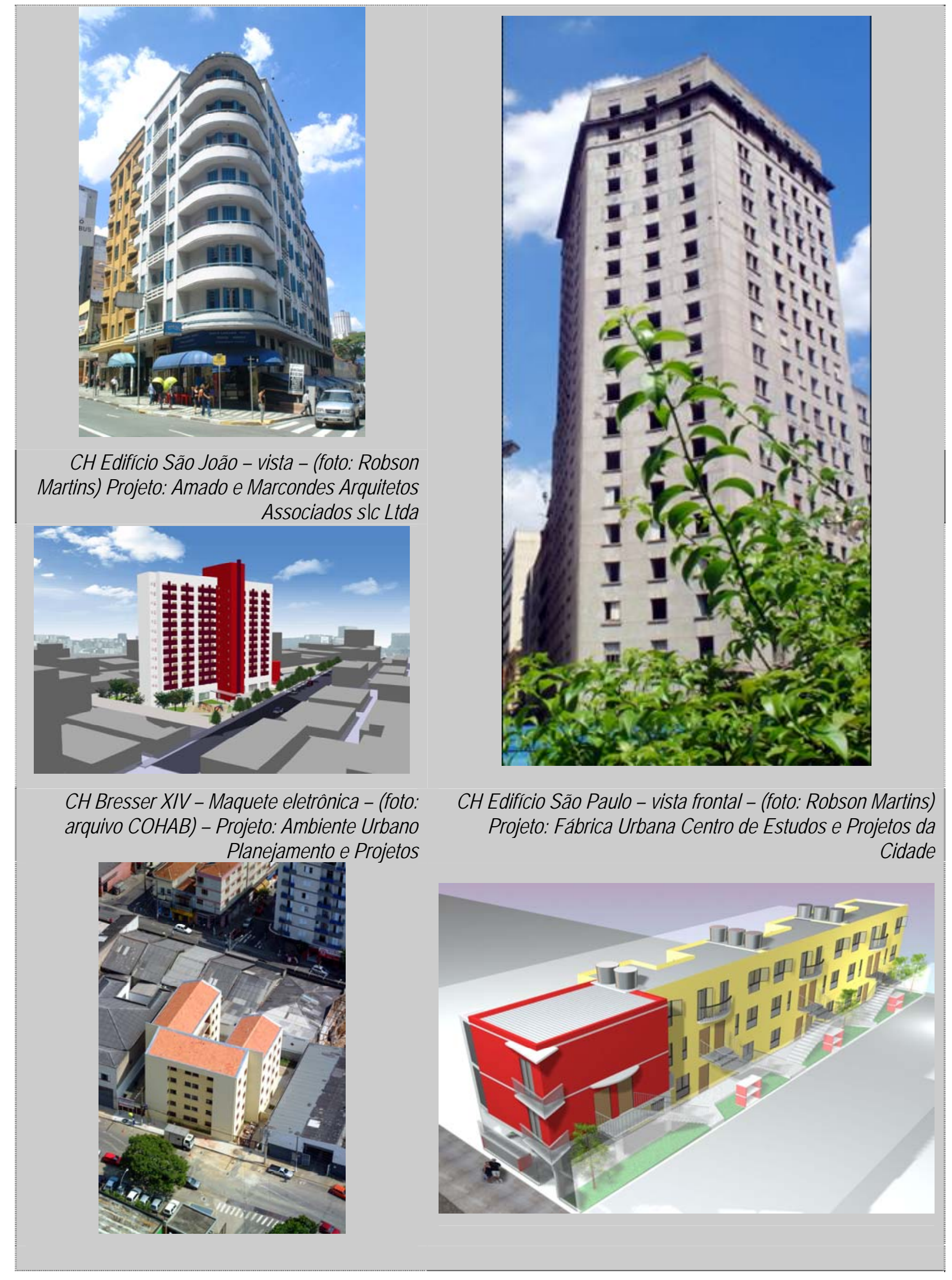




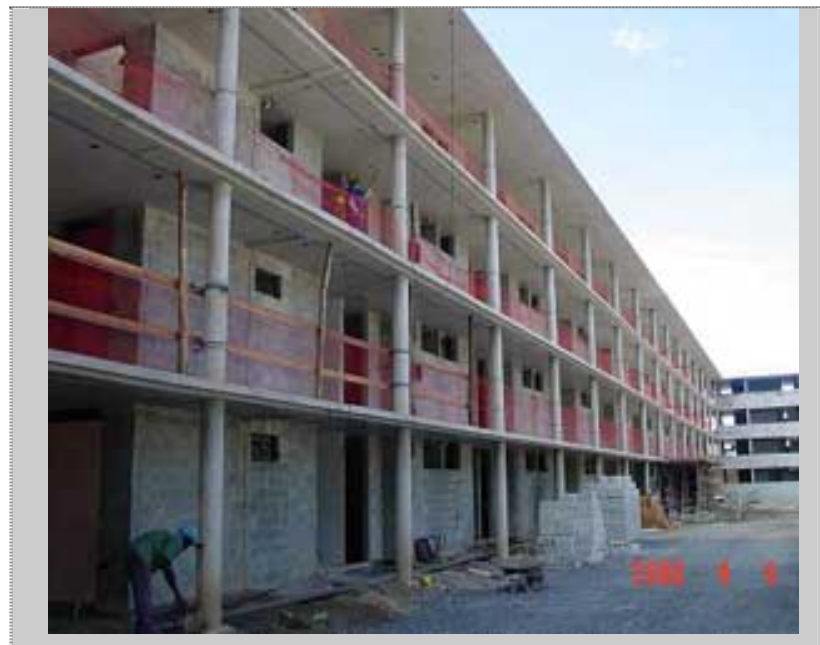

CH Pari I - obra - (foto: arquivo COHAB)- Projeto: Hector Vigliecca

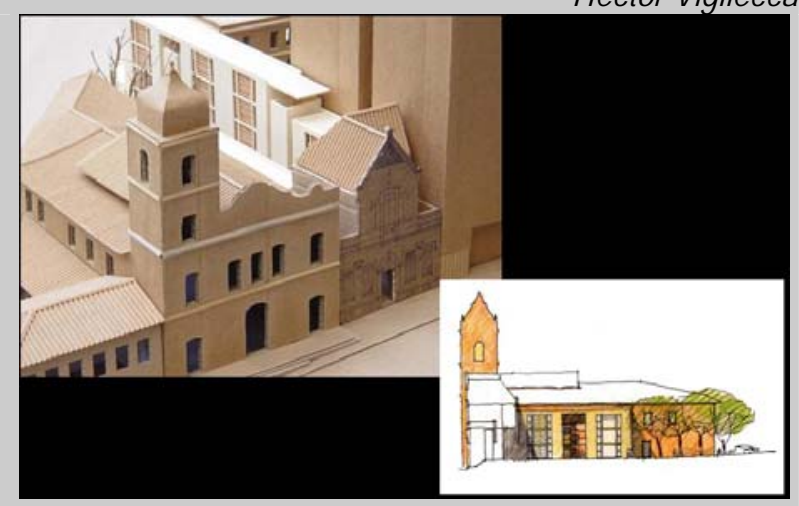

CH Casarão do Carmo -Maquete - (foto: arquivo COHAB) - Projeto: Hector Vigliecca

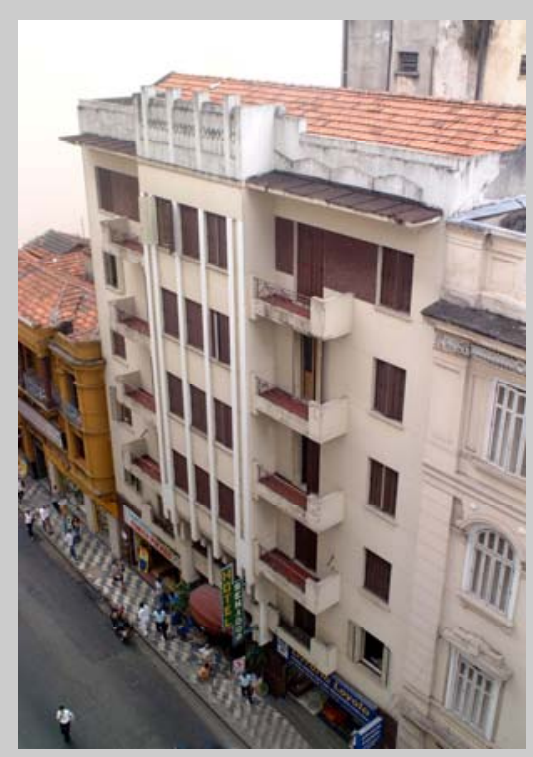

CH Senador Feijó - vista aérea - (foto:Robson Martins) Projeto: Barbosa e Corbucci Arquitetos Associados

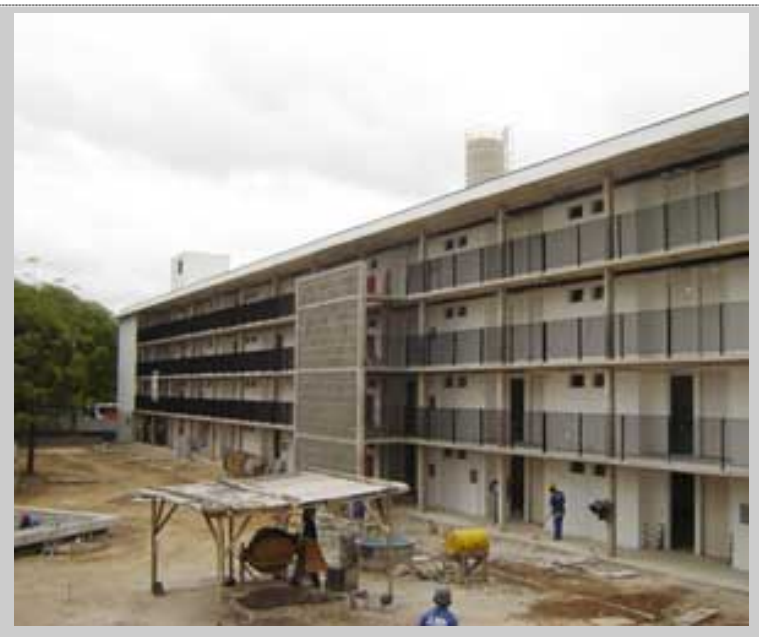

CH Pari I - obra - (foto: arquivo COHAB)- Projeto: Hector

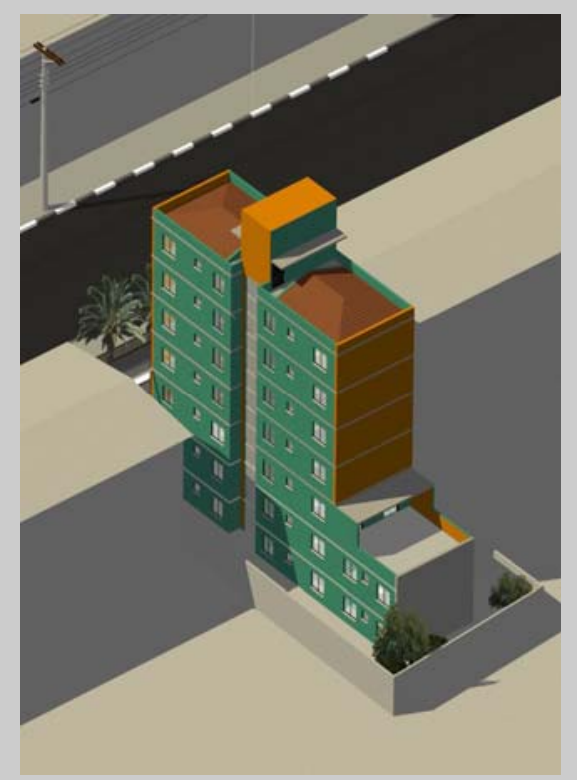

Vigliecca

CH Eiras Garcia - maquete eletrônica -(foto: arquivo COHAB) Projeto: Integra - Cooperativa de Trabalho Interdisciplinar

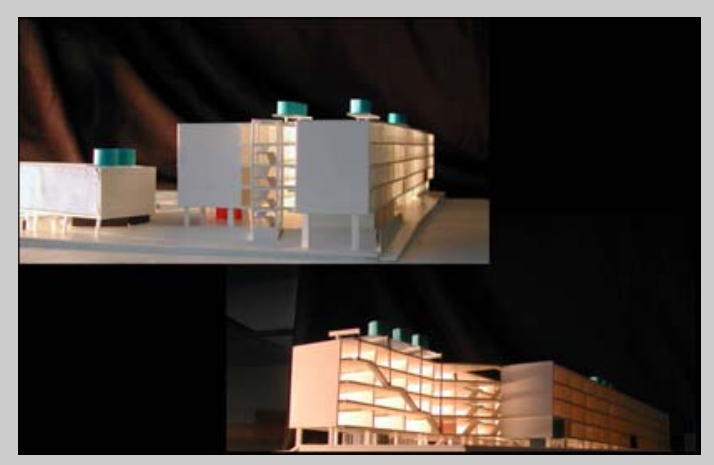

CH Cônego Vicente Marino - maquete eletrônica - (foto: arquivo $\mathrm{COHAB}$ - Projeto Frentes Arquitetura 

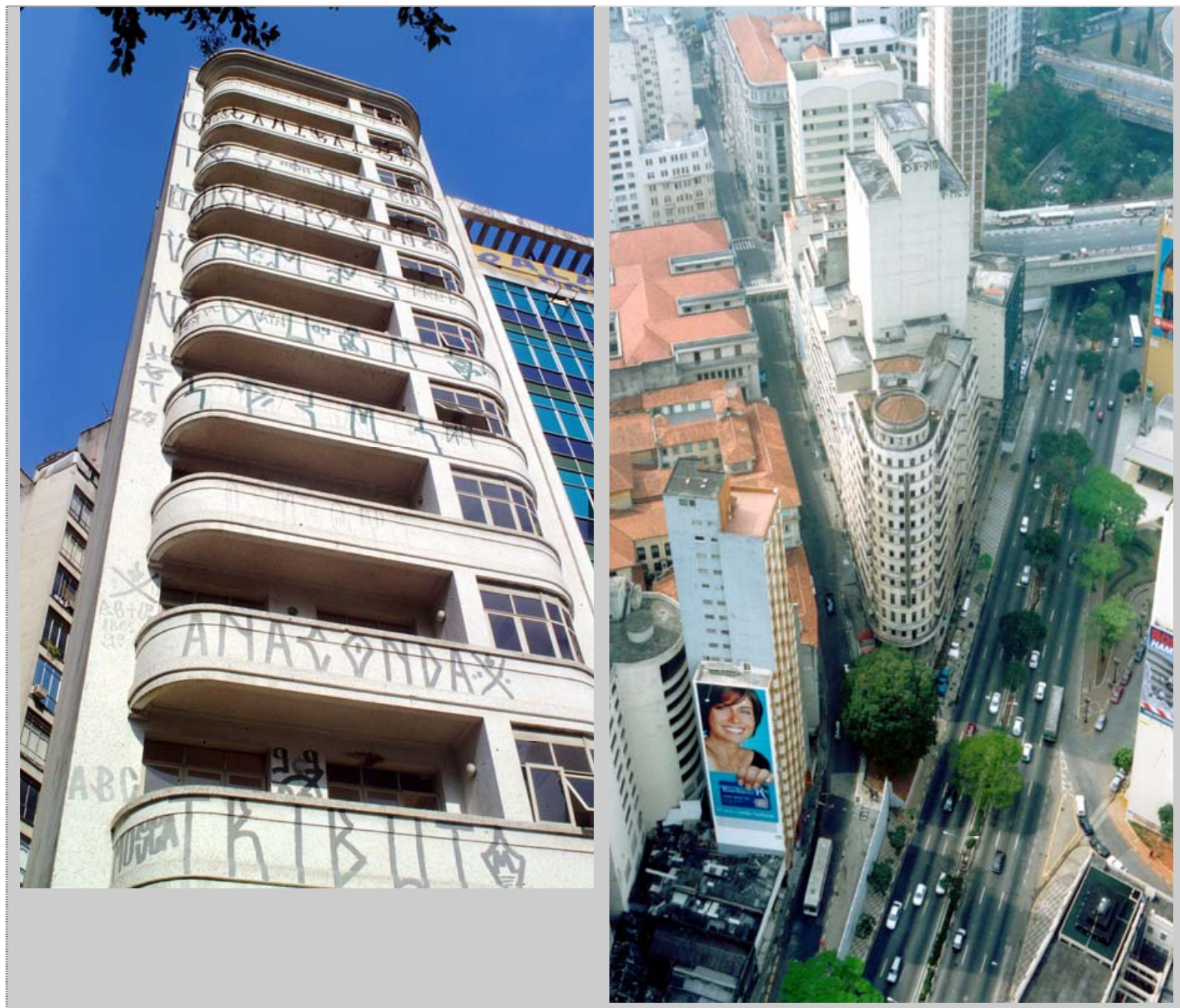

CH Asdrúbal do Nascimento - Vista - (foto: Robson Martins) - Projeto - Autografics Arquitetura e

CH Rua Riachuelo - vista aérea - (foto - arquivo COHAB) Projeto : Paulo Bruna Arquitetos Associados Planejamento Gráfico Ltda.

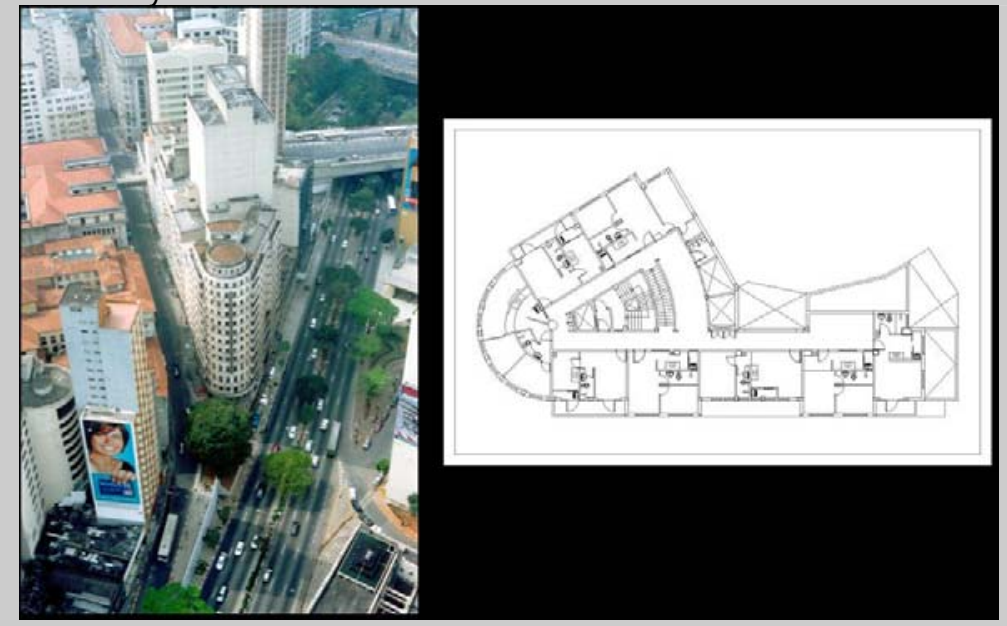

CH Rua Riachuelo - vista aérea - (foto - arquivo COHAB) - Projeto : Paulo Bruna Arquitetos Associados 


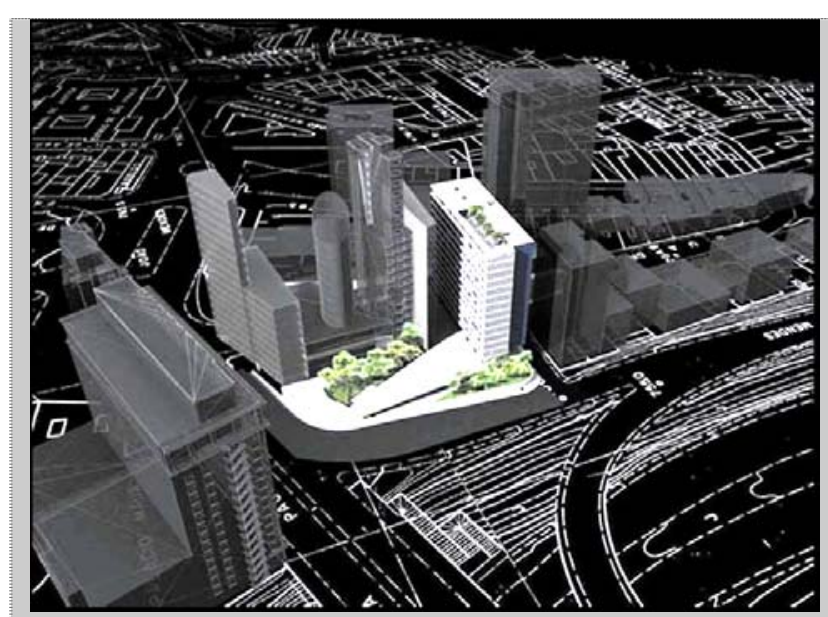

CH Assembléia - implantação - maquete eletrônica (foto: arquivo COHAB ) - Projeto: Andrade Morettin Projetos Associados

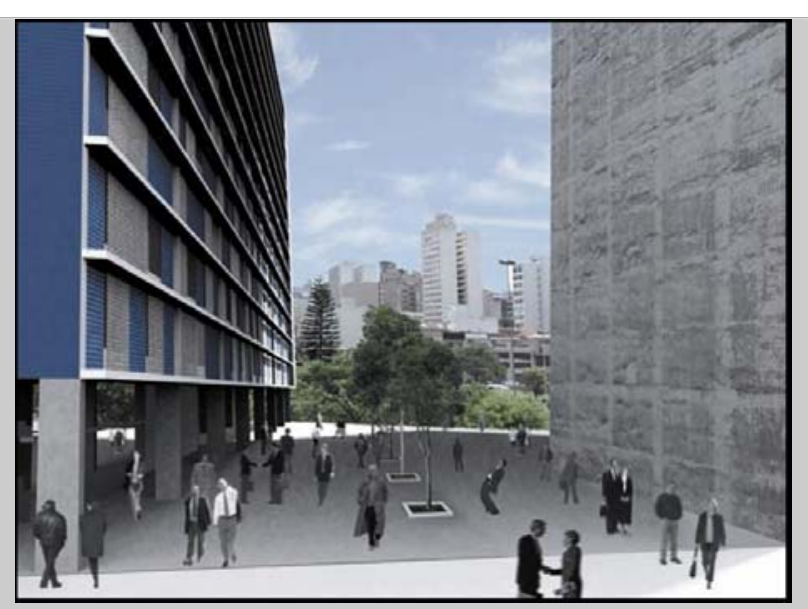

CH Assembléia - pátio interno - maquete eletrônica (foto: arquivo COHAB ) - Projeto: Andrade Morettin Projetos Associados

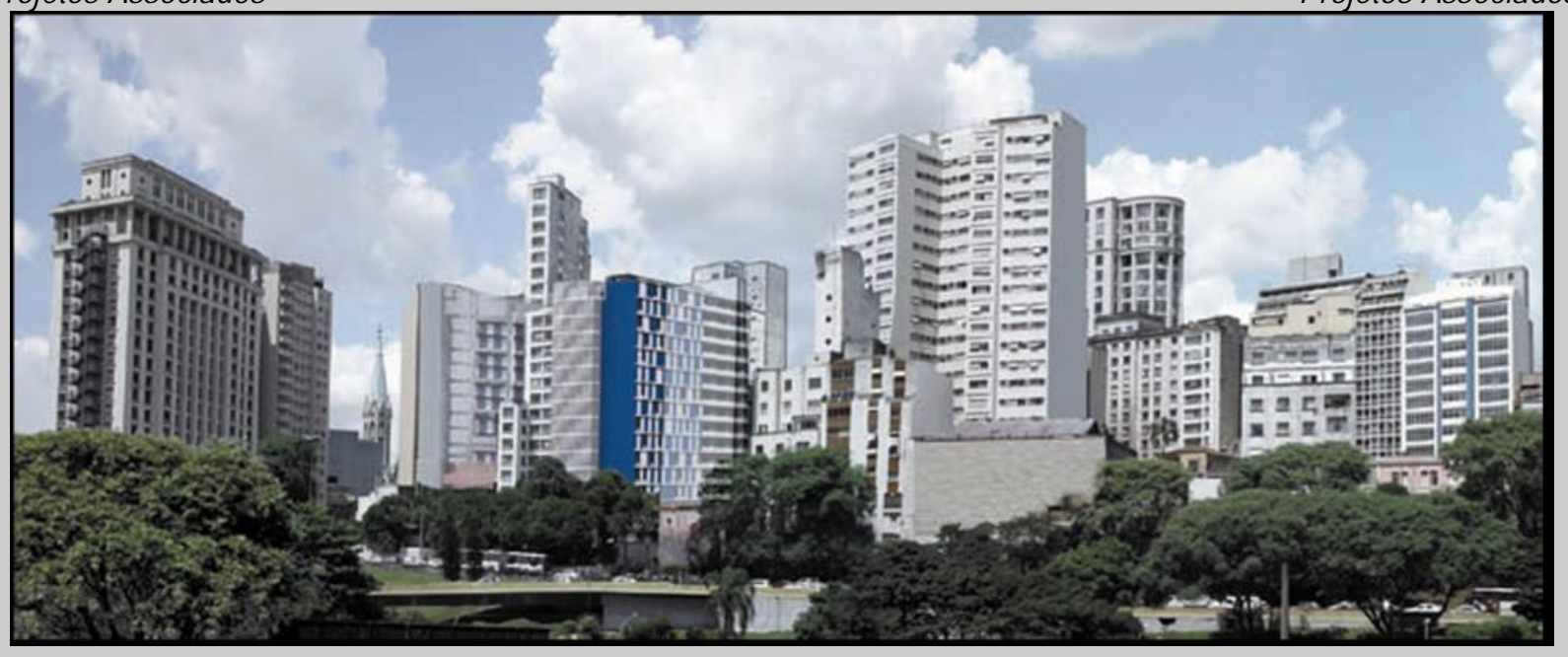

CH Assembléia - paisagem resultante após implantação em relação às edificações existentes - maquete eletrônica (foto: arquivo COHAB ) - Projeto: Andrade Morettin Projetos Assossiados

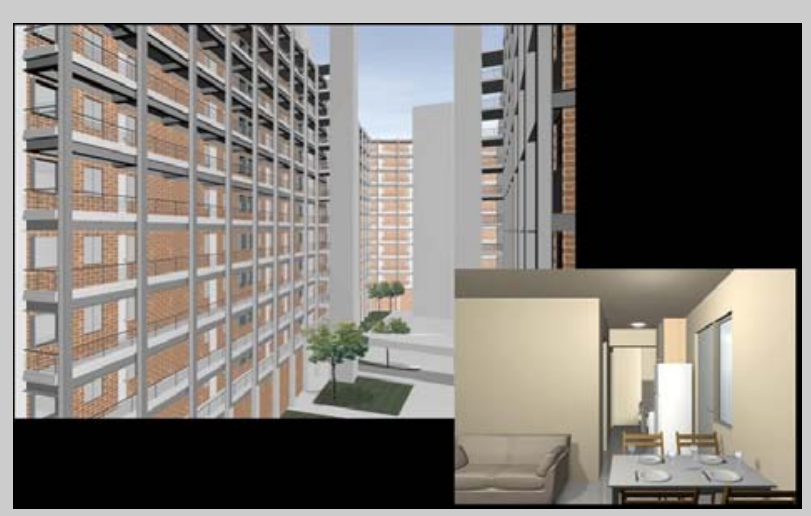

CH Metrô Belém - pátio interno e interior da residência maquete eletrônica - (foto: arquivo COHAB) - Projeto: Minoru Naruto

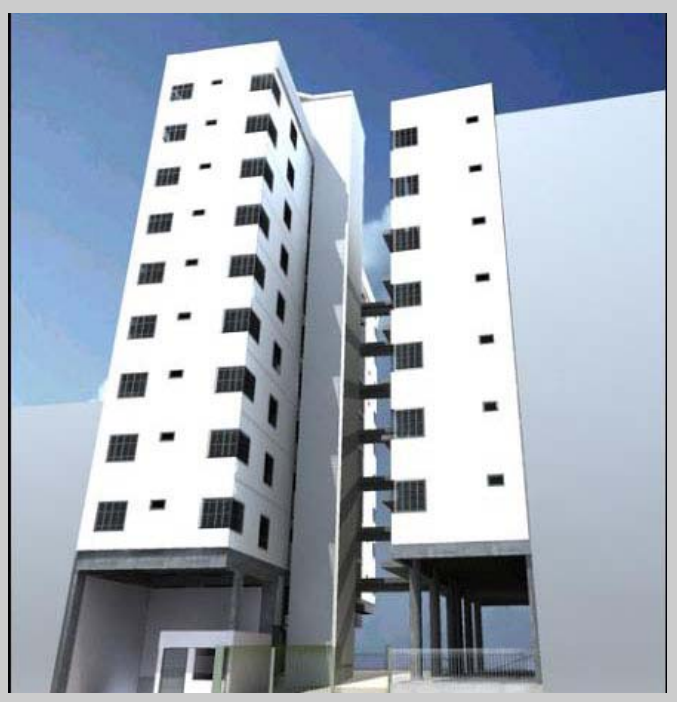

CH Carlos Gomes - vista frontal - maquete eletrônica (foto: arquivo COHAB) - Projeto : Barbosa e Corbucci Arquitetos Associados 


\section{Capítulo 6}

\section{Alguns paralelos}

Neste capítulo, serão feitas algumas comparações, alguns cruzamentos entre o que a COHAB-SP havia executado, ao final de 2004, e:

- o que havia realizado em períodos anteriores;

- as propostas do Programa de Governo de Marta Suplicy para a gestão 20012004;

- as metas/ propostas colocadas pelo planejamento que a companhia havia feito e pela $1^{a}$. Conferência Municipal de Habitação;

- a demanda por HIS no MSP, indicada pelo Plano Municipal de Habitação.

Tabela 6.1 - Metas propostas e resultados atingidos pela COHAB, relativos à oferta de novas moradias (em número de UH's)

\begin{tabular}{|c|c|c|c|c|}
\hline \multirow{2}{*}{\multicolumn{2}{|c|}{$\begin{array}{l}\text { Programas previstos para serem executados } \\
\text { pela COHAB }\end{array}$}} & \multirow{2}{*}{$\begin{array}{c}\text { Metas propostas } \\
\text { pela COHAB (Painel } \\
\text { sobre Provisão da } 1^{a} . \\
\text { Conf. Mun. Hab.) }\end{array}$} & \multicolumn{2}{|c|}{ Atingido até dez/04 } \\
\hline & & & Concluído & $\begin{array}{l}\text { Viabilizado } \\
\quad \text { (inclui } \\
\text { "Concluído") }\end{array}$ \\
\hline \multicolumn{2}{|c|}{$\begin{array}{l}\text { Construção de conjuntos habitacionais em } \\
\text { parceria com a CDHU }\end{array}$} & 5.000 & 930 & 3.800 \\
\hline \multicolumn{2}{|c|}{$\begin{array}{l}\text { 2- Construção de conjuntos habitacionais em } \\
\text { parceria com a CEF/PAR. }\end{array}$} & 5.000 & 1.260 & 4.135 \\
\hline \multicolumn{2}{|c|}{$\begin{array}{l}\text { Conclusão de mutirões iniciados entre } 89 \text { e } \\
92 \text {, com recursos do FMH. }\end{array}$} & 7.755 & 6.657 & 6.795 \\
\hline \multicolumn{2}{|c|}{$\begin{array}{l}\text { 4- Construção de novos empreendimentos por } \\
\text { mutirão com recursos do FMH }\end{array}$} & 4.245 & 790 & 6.949 \\
\hline \multicolumn{2}{|c|}{$\begin{array}{l}\text { 5- Construção de CH's por empreitada p/ } \\
\text { demanda de favelas, com recursos do FMH }\end{array}$} & 4.800 & 120 & 120 \\
\hline \multicolumn{2}{|c|}{$\begin{array}{l}\text { Conclusão obras empreitadas com recursos } \\
\text { do } \mathrm{FMH} \text {, iniciadas nas gestões anteriores. }\end{array}$} & 2.389 & 1.627 & 1.627 \\
\hline \multirow[b]{2}{*}{$\begin{array}{l}\text { 7- habitacionais do } \\
\text { programa de } \\
\text { requalificação do centro }\end{array}$} & PAR & \multirow{2}{*}{\begin{tabular}{|c|} 
Como meta estava \\
definido que deveria \\
executar $100 \%$ desse \\
programa. $E$ \\
executou.
\end{tabular}} & $\ldots \ldots \ldots$ (a) & 527 \\
\hline & $\begin{array}{l}\text { Loc. Social, Interv. } \\
\text { Cortiços (FMH, } \\
\text { BID, PEHP) }\end{array}$ & & 691 & 2.797 \\
\hline \multicolumn{2}{|r|}{ Subtotal } & \begin{tabular}{|r|}
29.189 \\
\end{tabular} & 12.075 & 26.750 \\
\hline \multicolumn{2}{|l|}{ 8- Bolsa-aluguel (FMH) } & \multirow{2}{*}{$\begin{array}{c}\text { Nao toram detınıdas } \\
\text { metas para essas } \\
\text { intervs., na } 1^{\text {a }} \text {. Conf. } \\
\text { Mun. Hab. }\end{array}$} & 2.600 & 2.600 \\
\hline \multicolumn{2}{|l|}{ 10- Moradia transitória (FMH) } & & 100 & 100 \\
\hline & Subtotal & - & 2.700 & 2.700 \\
\hline & Total & 29.189 & 14.775 & 29.450 \\
\hline
\end{tabular}

Fontes:

COHAB-SP, "Relatório de Gestão 2001-2004", 2004

- COHAB-SP, "Slides da Apresentação no Painel sobre Provisão", na 1a. Conferência Municipal, 2001 
$\mathrm{Na}$ Tabela 6.1, foram colocadas as metas que haviam sido propostas para a $\mathrm{COHAB}$, na $1^{\text {a }}$. Conferência Municipal de Habitação e no seu Planejamento Estratégico (Capítulo 4, Item 4.1), ao lado dos números que foram atingidos ao final de 2004.

Nessa tabela, pode ser observado que a COHAB, entre 2001 e 2004, viabilizou a construção de 26.750 uh's, das quais concluiu a construção de 12.075 uh's, e atendeu a 2.600 famílias no Programa Bolsa Aluguel e a 100 famílias em moradias transitórias. No total, havia "viabilizado" o atendimento de 29.450 famílias e entregado (ou estava prestes a entregar) moradias para 14.775 famílias, entre moradias definitivas e transitórias. Se se comparar o total viabilizado com o total das metas (29.189), o primeiro supera em pouco o segundo.

No entanto, verifica-se que foi atingida a metade do que se tinha como meta, quando se considera o total de uh's entregues (14.775 fams.), que envolve tanto aquelas para ocupação definitiva, quanto aquelas para ocupação transitória. Mas teria sido atingido $41,4 \%$ das metas, considerando apenas o que se entregou de moradias definitivas (12.075).

O conceito de "viabilizado" foi colocado pois se entendeu que, antes da entrega, havia um processo longo, com um grande número de atividades, para que ela fosse efetivada e que mereceria ser considerado. Para serem incluídos na categoria dos "viabilizados", os empreendimentos deveriam já ter garantida a terra, o projeto e o financiamento. Dentre esses, havia empreendimentos em etapas diversas. Tanto aqueles cuja licitação de obra estava sendo concluída (por exemplo: Belém e Bresser XIV), quanto aqueles cuja obra já estava em fase avançada (por exemplo: Itaquera IV -1.100 uh's- com 50\% das obras executadas em novembro de 2004). Este autor entende que, inclusive, seria positivo que esse conceito de "viabilizado" fosse disseminado, porque nas avaliações das administrações públicas, sobretudo naquelas feitas pela imprensa, há uma tendência para se considerar apenas obras concluídas e para se desconsiderar o processo de viabilização de obras, que é fundamental e, geralmente, mais difícil que a própria construção, e isso contribui para que as administrações tendam a privilegiar as ações que permitam resultados no curto prazo, que permitam inaugurações e tendam a negligenciar as ações de médio prazo. 
Alguns empreendimentos importantes, como o Residencial São Paulo Itaquera 1D (1.694 uh's) e o Bresser VI (160 uh's), preencheram parte dos requisitos para que fossem considerados viabilizados, pois dispunham de terra e projeto, mas não houve tempo para que tivessem o financiamento amarrado. Porém, tais empreendimentos não seriam computados entre os de HIS, pois seriam destinados ao atendimento de uma população de renda média.

Essa dissertação não tem a pretensão de apontar de forma mais assertiva para quais teriam sido os fatores que influenciaram o desempenho da COHAB-SP, na oferta de novas unidades. Isso mereceria uma pesquisa específica e com metodologia mais apropriada. Mas não estará sendo leviana se apontar alguns dos fatores que seriam mais significativos para que não se alcançasse plenamente as metas que foram colocadas para essa Companhia. Pelas observações realizadas, 4 fatores se evidenciam como aqueles que mais teriam dificultado para que houvesse uma maior agilidade e que fossem alcançadas mais plenamente as metas que foram postas.

\section{- Necessidade de se buscar novas fontes de recursos:}

Como já foi dito, a precária situação financeira da PMSP e da COHAB, no final da gestão Pitta (1997-2000), exigiu que a SEHAB e esse Companhia realizassem muitos trabalhos objetivando a captação de recursos de fontes diversas do orçamento municipal. A necessidade de se captar esses recursos fora da Prefeitura dificultou o deslanche de projetos pela $\mathrm{COHAB}$, pois, de um lado, havia a incerteza sobre se seriam obtidos e, de outro, a montagem dos processos visando a essa captação consumiu horas de trabalho de profissionais que deveriam estar envolvidos com as atividades de produção.

\section{- Acompanhamento/gestão do planejado:}

Apesar de ter sido muito positiva a realização dos trabalhos de planejamento estratégico desde os primeiros dias da gestão e sua divulgação para a grande maioria dos funcionários, houve uma certa dificuldade para que ele fosse destrinchado pelo conjunto dos responsáveis pela sua execução. O planejamento operacional na produção habitacional não é uma tarefa fácil, pelo grande número de 
variáveis (fundiárias, técnicas, relacionadas a remoções de famílias, a licitações, a licenciamento para construir, etc.) e agentes envolvidos, além disso, não são muitos os técnicos da área com experiência acumulada na matéria e, inicialmente, havia uma certa precariedade no instrumental de que se dispunha (softwares, banco de dados, computadores, etc.). Também foi relativamente tardia (início de 2003) a criação da figura dos gestores de programa: poucos funcionários que compuseram uma estrutura enxuta, mas que aliviou as áreas técnicas de muitos trabalhos, tais como, interlocução com a demanda (caso do PAR), com os órgãos de financiamento, etc.; que realizou uma costura transversal entre as atividades das várias áreas e passou a monitorar as ações mais de perto, tendo em vista os prazos.

- Dificuldade para se adquirir terras e prédios.

A dificuldade para se adquirir terras e prédios, tratada no item 5.1, e foi um dos maiores obstáculos para o deslanche de empreendimentos, principalmente, os do Programa Morar no Centro.

\section{- Empreendimentos de pequeno porte:}

Um bom número de empreendimentos de pequeno porte foi executado. Por exemplo: Imoroty (8 uh's), Pedro Fachini (12 uh's) e Eiras Garcia (15 uh's). Para serem executados, tais empreendimentos demandam uma quantidade de trabalho das equipes técnicas quase ou tão grande quanto os empreendimentos de maior porte. Por exemplo, a licitação da obra de um pequeno conjunto habitacional demanda tanto trabalho quanto a de um grande. Em razão da diretriz de se buscar terrenos melhor inseridos na cidade e em razão de especificidades como a dos empreendimentos mencionados, implantados para atender a moradores de cortiços que haviam se mobilizado visando a esse atendimento, a tendência é para que se tornem mais freqüentes terrenos de pequenas dimensões. Mas é importante que se atente para esse fato. 


\section{- Necessidade de se equacionar a retomada de obras:}

A necessidade de se resolver a retomada de obras paralisadas ou que andavam em ritmo lento, tantos as do Programa de Mutirões, quanto aquelas por empreiteiras que estavam com problemas contratuais e/ou de liberação de recursos, também exigiu muito trabalho.

\section{Tabela 6.2 - Número de UH's iniciadas e concluídas por gestão}

\begin{tabular}{l|c|c|c}
\hline \multicolumn{1}{c|}{ Gestão } & Período & $\begin{array}{c}\mathbf{N}^{\circ} \text { uh's } \\
\text { iniciadas }\end{array}$ & $\begin{array}{c}\text { No uh's } \\
\text { concluídas }\end{array}$ \\
\hline Faria Lima & 08.04 .65 a 07.04 .69 & 1.917 & 1.917 \\
\hline Paulo Maluf & 08.04 .69 a 07.04 .71 & - & - \\
\hline Paulo Maluf/ F. Ferraz & 71 & 7.681 & - \\
\hline Figueiredo Ferraz & 07.04 .71 a 21.08 .73 & - & 5.840 \\
\hline Miguel Colasuono & 28.08 .73 a 16.08 .75 & - & - \\
\hline Olavo Setúbal & 17.08 .75 a 11.07 .79 & 15.284 & 5.911 \\
\hline Setúbal/ R.Barros & 79 & 6.432 & - \\
\hline Reynaldo de Barros & 12.07 .79 a 14.05 .82 & 34.922 & 32.772 \\
\hline R. Barros/Curiati & 82 & 13.889 & - \\
\hline Salim Curiati & 15.05 .82 a 14.03 .83 & - & 17.921 \\
\hline Curiati/Covas & 83 & 4.996 & - \\
\hline Mário Covas & 10.05 .83 a 31.12.85 & 7.447 & 22.400 \\
\hline Jânio Quadros & 01.01 .86 a 31.12.88 & 39.359 & 15.737 \\
\hline Luiza Erundina & 01.01 .89 a 31.12.92 & 804 & 27.399 \\
\hline L. Erundina (mutirões HABI/COHAB) & 01.01 .89 a 31.12.92 & 6.795 & - \\
\hline Paulo Maluf & 01.01 .93 a 31.12.96 & 2.465 & 4.759 \\
\hline Celso Pitta & 01.01 .98 a 31.12.00 & 440 & 980 \\
\hline Marta Suplicy & 01.01 .01 a 31.12.04 & 9.388 & 12.075 \\
\hline & Total & 151.819 & 147.711 \\
\hline
\end{tabular}

Fontes:

COHAB-SP, Diretoria Técnica, Relatório "Produção Habitacional pela COHAB-SP", 18.04.2001. apud. SILVA, MGP, 2004, p. 29

SLOMIANSKY, 2002, p. 215

COHAB-SP, 2004

Obs.: O número de 9.388 uh's iniciadas na gestão Marta Suplicy resultam da soma de 292 do Programa Bairro Legal (Heliópolis N (172) e Lidiane II (120)); 460 da Parceria c/ a CDHU (Jd. das Acácias); 1.111 do Morar no Centro (inclusive o Hotel SP); 4.135 do PAR-COHAB (exclusive o Hotel SP); e de 3.390 dos Mutirões c/ Autogestão, sendo 753 da $3^{\text {a. }}$ Geração e 2.637 da $1^{\text {a. }}$ Ger.(2 $2^{\text {a. }}$ e $3^{\text {a. }}$ etapas $)$ e da $2^{\text {a. }}$ Geração.

Observando-se a Tabela 6.2 e os quadros da produção da COHAB-SP ao longo da história, mostrados no Capítulo 1 - Item 1.1, verifica-se que a gestão Marta Suplicy entregou mais unidades habitacionais que as gestões Celso Pitta (980), 
Paulo Maluf (4.759) e todas as que antecederam a de Reynaldo de Barros (32.772). Mas concluiu um número menor do que essa gestão e as gestões Salim Curiati (17.921), Mário Covas (22.400), Jânio Quadros (15.737) e Luiza Erundina (27.399).

Em relação às obras iniciadas, a gestão de Marta Suplicy iniciou por intermédio da COHAB-SP a construção de 9.388 uh's, número superior aos apresentados pelas duas gestões de Paulo Maluf e as de Celso Pitta, Luiza Erundina, Miguel Colasuono, Figueiredo Ferraz, Faria Lima. Mas inferior aos das gestões Jânio Quadros, Reynaldo de Barros e Olavo Setúbal. Como os dados disponíveis referem-se ao ano de início da obra e não ao dia e mês, e como o início e o término de algumas gestões não coincidiram com o início e término de um determinado ano, não foi possível saber os números corretos sobre o início de obras de todas as gestões e isso não permitiu uma comparação da gestão de Marta Suplicy com as de Mário Covas e Salim Curiati. Pois se uma parcela das obras iniciadas no ano que foi comum às duas gestões for computada para uma ou outra, os números dessa gestão poderão superar os da de Marta Suplicy. Um aspecto importante a considerar sobre os números da produção é que 6.657 uh's do Programa de Mutirões com Autogestão, que haviam sido iniciadas na gestão de Luiza Erundina, através de $\mathrm{HABI}$, foram concluídas pela $\mathrm{COHAB/FMH}$, na gestão de Marta Suplicy.

Uma comparação entre gestões tem que considerar o contexto histórico, as condições diferenciadas a que estavam submetidas. Muito brevemente, aqui, serão pontuados alguns aspectos das mudanças das condições sob as quais a COHAB atuou. Até a gestão Luiza Erundina -inclusive-, essa companhia contou com financiamentos significativos do SFH, que haviam sido contratados em gestões anteriores, mas que se escassearam posteriormente. E o MSP teve que passar a contar com recursos próprios ou de outras fontes de financiamento (BID, BIRD, CDHU, CEF/PAR, etc), mas que ofereciam montantes menores que os dos bons momentos do SFH e colocavam um grau maior de dificuldade para serem acessados.

Quanto às terras, no município de São Paulo, como em sua região metropolitana, foram rareando as glebas de maiores dimensões e com características adequadas para a implantação de conjuntos habitacionais. Quanto 
aos projetos, tornaram-se mais complexos, por um lado, porque a verticalização passou a predominar e, evidentemente, a exigir que contivessem um maior detalhamento. E, por outro lado, porque tiveram que passar a observar com mais atenção a legislação, pois não pôde ser mantida a relativa negligência com que, antes, era tratado o licenciamento, em razão de uma atuação mais firme dos órgãos que por ele são responsáveis e dos órgãos do judiciário, principalmente do Ministério Público, na aplicação da legislação urbanística, edilícia, ambiental, de licitação e de proteção ao consumidor. É importante não perder de vista que, nos 40 anos de história da $\mathrm{COHAB}$, cujo desempenho na esfera da produção está sendo observado, muitas mudanças aconteceram no país. Ocorreu o início e término de uma ditadura militar, após a qual o Judiciário, o Legislativo, os Tribunais de Contas, a sociedade civil passaram a ter maior presença e a questionar com maior freqüência as ações de órgãos e empresas do Estado, como a COHAB. Ou seja, a COHAB deixou de ter toda a liberdade que tivera para adquirir terras, desenvolver seus projetos e executar suas obras.

Em 2004, ano de sua publicação, o Plano Municipal de Habitação - PMH (PMSP/SEHAB, 2004), abordado no Item 3.1, do Capítulo 3, estimou que, no município, havia necessidade de provisão de 62.294 novas uh's (p. 32). E que haveria um acréscimo da demanda por novas moradias, chegando-se a 99.050 uh's (p.69), até 2012, ano em que deveriam ser atingidas as metas de atendimento que ele (Plano) coloca.

Os principais agentes promotores que atuam na provisão de HIS, hoje no MSP, são a CEF, a CDHU e a COHAB-SP. Para imaginar qual seria a parcela de trabalho que caberia à COHAB, na produção dessas 99.050 uh's, podem ser feitos alguns exercícios sobre como seria uma divisão de tarefas entre esses agentes promotores.

A CEF tradicionalmente não é um agente promotor e sim financeiro. Só tendo assumido essa primeira função com o advento do PAR. A função de agente promotor, além de uma boa estrutura para a contratação e fiscalização de obras, requer uma razoável estrutura para a habilitação da demanda e para a gestão dos contratos a serem firmados com mutuários ou arrendatários. Estrutura à qual vai caber não só a estrita administração dos contratos e o recebimento dos 
pagamentos, mas também lidar com situações tais como: a necessidade de famílias terem que se mudar; de estarem incapacitadas de efetuar os pagamentos; de conflitos na administração dos condomínios (em que, no mínimo, quando se trata de arrendamento ou locação social, é inevitável a presença/mediação do agente promotor) etc. Situações que, por se tratarem de famílias de muito baixa renda e de alta vulnerabilidade, demandarão a análise e o esforço para o equacionamento de profissionais da área social e não apenas de profissionais da área de cobrança ou da área jurídica para mover ações de reintegração na posse.

Ao que parece a estrutura que a CEF possui é, razoavelmente, adequada para cuidar da contratação e fiscalização de obras. Mas não parece suficientemente adequada para um trabalho de gestão de contratos com mutuários e arrendatários (e eventualmente locatários) em que haja necessidade de uma boa bagagem de atuação na área social. Para cuidar da definição das famílias que ocupariam os empreendimentos do PAR e do seu pós-ocupação, a CEF terceirizou serviços, contratando administradoras de condomínios. O contato que a COHAB e a HABI tiveram com a CEF para a definição das famílias que seriam atendidas pelo PAR apontou que grande parte dessas terceirizadas realizou um trabalho muito precário. Até porque são raras as entidades capacitadas para esse tipo de serviço, que precisam reunir pessoal especializado em administração de condomínios, contas a pagar, contas a receber, mas também com boa experiência em trabalhos com a população. Essa foi uma das dificuldades que a SEHAB e a COHAB previam que ser enfrentadas, caso houvesse, como se pretendia, uma terceirização de serviços de administração de condomínios no Programa de Locação Social.

Dessa forma, nesse exercício de divisão de trabalhos, será considerando que a parcela que caberá à CEF como agente promotor será de 2.000 uh's/ ano, que é um número da ordem de grandeza da entrega de obras do PAR.. Evidentemente, que, como agente financeiro, sua principal função, a CEF estará envolvida com um montante superior a esse.

A CDHU, durante seus 40 anos de atuação (1967 a 2006), executou ${ }^{77}$ :

- no MSP, 72.840 uh's, com média de 1.821 uh's/ano;

\footnotetext{
${ }^{77}$ Site da CDHU (www.cdhu.sp.gov.br/aplicacoes/internauta/perfil/oferta/uh gestao.pdf), acessado em 05/05/2007.
} 
- na RMSP exceto MSP, 50.279 uh's, com média de 1.521 uh's/ano; e

- no interior e litoral do ESP, 286.827 uh's, com média de 7.171 uh's/ano.

Totalizando 409.945 uh's em todo o Estado, com uma média de 10.249 uh's/ano.

No entanto, se se considerar os 12 anos entre 1996 e 2006, período em que essa companhia estadual priorizou o MSP, verifica-se que, nele, produziu 58.018 uh's, com uma média de 4.835 uh's/ano e, portanto, será considerado que, nessa divisão de trabalho, caberá à CDHU a produção de 4.800 uh's/ano.

Dessa forma, com a CDHU e a CEF, na condição de agente promotor, entregando 6.800 uh's/ano, seria necessário que a COHAB-SP entregasse 5.581 uh's/ano, para que, em 8 anos, fosse oferecido o número de novas moradias apontado pelo PMH como necessárias pelo até 2012.

A essa produção anual corresponderia a uma produção de 22.325 uh's em cada gestão de quatro anos. Número semelhante ou superior só foi atingido nas gestões dos prefeitos Reynaldo de Barros, Mário Covas e Luiza Erundina, em relação à conclusão de obras. E quanto ao início de novas obras, apenas nas gestões de Reynaldo de Barros e Jânio Quadros. Ou seja, é um número muito expressivo, mas que a COHAB já chegou a atingir em alguns momentos, se bem que poucos. Mas também é necessário ponderar que, como já foi dito, as condições para a produção de moradias em larga escala no MSP são mais difíceis hoje do que no passado, em função do escassez de terras com características e preços adequados à HIS e em função de uma maior complexidade dos projetos.

Tab. 6.3 - Estimativa de produção necessária visando as metas do Plano Municipal de Habitação

\begin{tabular}{l|r|r|r}
\hline \multirow{2}{*}{ Instituição } & \multicolumn{3}{|c}{ Produção } \\
\cline { 2 - 4 } & em 8 anos & por ano & por gestão \\
\hline CEF & 16.000 & 2.000 & 8.000 \\
\hline CDHU & 38.400 & 4.800 & 19.200 \\
\hline COHAB-SP & 44.650 & 5.581 & 22.325 \\
\hline Total & 99.050 & $\mathbf{1 2 . 3 8 1}$ & $\mathbf{4 1 . 5 2 5}$ \\
\hline
\end{tabular}

Fonte: elaboração do autor 


\section{Considerações finais}

Colocou-se para este trabalho a proposta de observar como a COHABSP, desempenhou o papel que the coube na execução da política habitacional implantada no período 2001-2004, focando nas suas áreas de atuação mais relacionadas à oferta de novas moradias. Nessa observação pretendia-se estimar potencialidades para trabalhos de maior envergadura, que são requeridos para o equacionamento da questão da habitação social no município de São Paulo. Colocava-se também uma hipótese de que essa política habitacional possuía muitas características que a tornava diferente daquelas dos períodos anteriores e que traduziam o conjunto de idéias com as quais se identificavam as propostas do Partido dos Trabalhadores, de outros partidos de esquerda, dos movimentos mais organizados e de boa parte dos técnicos do setor.

A estrutura desse trabalho buscou fornecer elementos para a discussão das questões colocadas acima:

No Capitulo 1 -Elementos da história da COHAB-SP e das políticas habitacionais do município de São Paulo-, foram apresentados elementos sobre a evolução histórica da COHAB e das políticas municipais para HIS, e dados sobre a produção da COHAB ao longo do tempo. Expõem-se os caminhos paralelos que foram trilhados pela $C O H A B$ e pela $H A B I$ (Superintendência de Habitação Popular e os vários órgãos que a antecederam com denominações diferentes, mas atribuições semelhantes). A COHAB seguindo as diretrizes ditadas pelo Sistema Financeiro da Habitação (SFH) e a HABI seguindo orientações formuladas no âmbito do município e utilizando recursos, em grande parte do tempo, provenientes do FUNAPS, que teve como sua maior fonte o orçamento do município. A COHAB, em razão dessas diretrizes e da sua condição de sociedade anônima, obrigada a buscar o equilíbrio financeiro, a sustentabilidade dos financiamentos, impedida de conceder subsídios e com grande dificuldade para propor programas alternativos. A HABI voltada para as faixas de mais baixa renda e às intervenções em favelas, podendo conceder subsídios, inclusive intervir a fundo perdido.

Nesse capítulo, são expostas características do $\mathrm{SFH}$, as suas diretrizes, o ideário da "casa própria", dados da produção que financiou e é feita uma 
comparação dessa produção com a que se verificou numa série de países. Onde se constata que a produção do SFH, apesar ter atingido números significativos para o país e influenciado de forma importante a sua indústria de construção civil, numericamente, fica aquém da provisão habitacional de promoção estatal de muitos países.

E também são colocadas características institucionais e atribuições da COHAB, e informações sobre a constituição do Fundo Municipal de Habitação (FMH) e sobre o papel da COHAB como seu agente operador.

A implantação, em 1994, de um novo desenho institucional, com a criação do $\mathrm{FMH}$, em substituição ao FUNAPS, e a transferência à COHAB da atribuição de agente operador desse fundo municipal, anteriormente desempenhada por HABI, é um momento marcante na articulação da COHAB com os outros agentes das políticas municipais de habitação. A lei que instituiu o $F M H$ atribui à SEHAB a responsabilidade por "estabelecer a política municipal de habitação", "elaborar programas e projetos" e "propor a alocação de recursos". E cria o Conselho do Fundo Municipal de Habitação, do qual o Superintendente de HABI será o Secretário Executivo e o Secretário Municipal da Habitação será o Presidente. Dessa forma, define-se uma fonte de recursos para a COHAB, mas também se estabelece um regramento que ela deverá seguir. A questão das relações da COHAB, HABI e os fundos municipais para habitação (FUNAPS e FMH) é abordada de forma mais detida, no item 4.4., do Capítulo 4.

\section{No Capítulo 2 -As críticas mais freqüentes ao antigo modelo} COHAB-, foram apresentadas e discutidas as maiores críticas feitas ao modelo de atuação seguido pela COHAB na maior parte de sua história. Críticas essas que influenciaram a formação de um ideário sobre como deveriam ser as políticas habitacionais e que influenciou as propostas formuladas para a $\mathrm{COHAB}$, para o período 2001-2004.

São analisadas as políticas de aquisição de terras da COHAB, marcadas por uma busca por terrenos mais baratos nas zonas mais extremas da periferia da cidade, que, ao que parece não considerou os custos globais dos empreendimentos, porque, muitas vezes, optou-se por áreas desfavoráveis quanto à 
topografia e às características do solo, que exigiram grandes e caras obras de terraplanagem, drenagem e toda a infra-estrutura complementar. Dessa forma, invertia-se o raciocínio favorável às terras mais baratas. A implantação de tais conjuntos também acarretou impactos ambientais consideráveis: erosões, assoreamento de córregos, inundações, aterros de talvegues, remoção de vegetação significativa, inclusive de matas.

É discutido como as grandes distâncias e a má localização desses assentamentos impuseram maiores despesas e sacrifícios para os seus moradores, com grandes deslocamentos aos locais de trabalho e de serviços, e como contribuíram para que se criasse a idéia (às vezes, confirmada pela realidade; às vezes, não) de que são guetos e áreas de grande violência.

Ainda em relação à política de aquisição de terras, aborda-se a sua desarticulação com política urbana do município (enquanto existiu), a sua influência para o surgimento de novos vetores de crescimento para a cidade e sobre a valorização das terras da periferia.

Em relação aos projetos que a COHAB realizou, em grande parte de sua história (diretamente ou contratando escritórios ou, em grande número, por intermédio das construtoras), aponta-se para a excessiva padronização, a monotonia decorrente, a dificuldade para uma identificação dos moradores com seu local de moradia e para que sejam vistos como parte da "cidade normal", por terem características do que HUET (1986/1987) chamou de "jungles urbanas". Além dessas "qualidades", os projetos contribuíram para a elevação de custos, por demandarem grandes obras de terraplanagem e de infra-estrutura.

Também se apresenta idéias sobre o que teria motivado que os projetos possuíssem tais características: a concepção da "cidade ideal moderna", segundo COMAS (1986); e a supremacia da busca dos grandes números de moradias e da ótica das construtoras (massificação, padronização, ganhos pelas grandes escalas, utilização de equipamentos pesados, agilidade), segundo RUBANO (2001, p. 60), e o descaso pela possibilidade de se combinar escala de produção com projetos melhor resolvidos. 
Se a grande maioria dos projetos foi feita da maneira e sob as influências mencionadas, não seria de se esperar maiores cuidados com a aprovação/ regularização dos empreendimentos e com a execução das obras. Dessa forma, os longos prazos para se regularizar e permitir transferências de propriedade, etc. e o grande número de ações (judiciais e administrativas) envolvendo patologias nas construções, são heranças lamentáveis deixadas para os mutuários, para os quadros técnicos da Companhia e para as direções que, nela, se sucederam.

No Capítulo 3 -As condicionantes da política habitacional implantada entre 2001 e 2004-, busca-se formar um quadro da situação em que se encontrava o município e os seus principais agentes de formulação e execução de política habitacional (a SEHAB e a COHAB). Em relação à demanda por moradia, abordase o diagnóstico feito pelo Plano Municipal de Habitação, e o que coloca como metas e estimativas de recursos que poderão ser alavancados para habitação. Por um lado, esse Plano aponta uma situação já muito grave e estima que, até 2012, 771 mil domicílios precários e/ou em assentamentos precários terão que receber melhorias (urbanização, reforma, regularização) e 99 mil novas moradias terão que ser construídas. equacionar os dQuanto à situação da SEHAB e da COHAB, são expostos dados referentes à situação econômico-financeira da Prefeitura e da COHAB, aos compromissos (principalmente, pagamento da dívida com o SFH, obras em andamento, etc.) assumidos por essa empresa, e a sua dependência em relação ao orçamento municipal, decorrente, sobretudo, da alta inadimplência dos seus mutuários.

Nesse capítulo, também se observa o conjunto de idéias que a gestão Marta Suplicy trazia para a área de habitação da Prefeitura, basicamente aquelas contidas no Programa de Governo da candidata. Idéias que poderiam ser resumidas como: a visão da moradia como um direito social; a prioridade para as faixas de mais baixa renda e o reconhecimento da necessidade de subsídios para tornar efetiva essa prioridade; a proposta de articular a política habitacional ao conjunto da política urbana; o respeito ao meio ambiente; a adoção de uma maior diversidade de programas e de tipologias de projetos; a criação de espaços para a participação popular na formulação e execução das políticas; o reconhecimento da "cidade real"; a intenção de promover habitação social nas áreas centrais; o estímulo à autogestão. Idéias que, mesmo além do círculo de partidos e setores de esquerda, 
aparentemente, tornaram-se consensuais. Porque, no debate público, ninguém delas tem discordado, apesar de nem sempre serem aplicadas efetivamente, nas oportunidades em que a aplicação seria possível.

No Capítulo 4 -O desenho da nova política habitacional-, trata-se do processo de planejamento que definiu as principais linhas de atuação para a SEHAB e para a COHAB, e das principais metas para essa Companhia; e também de dois dos principais momentos desse planejamento: os seminários de planejamento estratégico realizados pela COHAB, no início de 2001 , e a $1^{\text {a }}$. Conferência Municipal de Habitação.

Observando o que se planejou, aborda-se o conjunto de diretrizes, linhas de ação e programas que configuraram a política municipal de habitação para o período 2001-2004, e a divisão de trabalho entre os vários setores da SEHAB e da COHAB. Comentando-se sobre as razões para que a intenção da COHAB de ficar com uma parte dos trabalhos (urbanização de favelas) não tenha se concretizado. Por essa divisão, excetuando o PROVER e o PROCAV, que continuaram a ser tocados por $\mathrm{HABI}$, ficou para a COHAB a responsabilidade pela execução dos demais programas de provisão habitacional: Mutirões com Autogestão, Arrendamento Residencial (PAR), Morar no Centro e o de Locação Social, a Parceria com a CDHU, o Bolsa Aluguel, a Carta de Crédito, a provisão habitacional para atendimento à demanda do Programa Bairro Legal e das Operações Urbanas Água Espraiada, Faria Lima e Jacú-Pêssego. E também da requalificação e regularização dos conjuntos habitacionais que havia construído ao longo de sua história, dentro do programa denominado Viver Melhor, e dos conjuntos financiados pelo FUNAPS. Bem como a responsabilidade do prosseguimento à quase totalidade dos programas e projetos em andamento, dentre eles, os empreendimentos do Programa Chamamento Empresarial, iniciados nas gestões Maluf e Pitta.

Além disso, a COHAB pôs em execução novos programas de modernização administrativa, de redução da inadimplência da sua carteira de mutuários, de recuperação da sua saúde financeira, etc.

Nesse capítulo, também são apresentados dados sobre a alocação dos recursos para as várias linhas de atuação e programas. Permitindo-se que se veja o 
peso dos recursos não-orçamentários e a sua distribuição pelas suas várias fontes. E a participação, ainda discreta, do $\mathrm{FMH}$ dentro da soma dos recursos destinados a habitação.

Ainda no Capítulo 4, trata-se, de forma breve, sobre os fundos públicos em geral e observa-se, mais detidamente, a constituição e o funcionamento do Fundo Municipal de Habitação e de seu Conselho. Aborda-se um certo debate que ocorreu ou ainda ocorre em torno das vantagens e desvantagens do Fundo ter a COHAB como seu agente operador e não um órgão da administração direta. Este trabalho conclui que o desenho institucional que se adotou, com a COHAB como agente operador do $\mathrm{FMH}$, conferiu a personalidade jurídica, que faltava ao FUNAPS. E propiciou agilidade em parte das ações relacionadas ao $\mathrm{FMH}$, principalmente, no que se relaciona à desapropriação de terras, à comercialização das unidades habitacionais construídas e à gestão de pessoal, mas que não há ainda suficiente clareza sobre um ganho de agilidade na licitação e contratação de projetos e obras, por estar a COHAB sujeita à mesma legislação que rege a administração direta. Da mesma forma, que não há suficiente clareza sobre um eventual aumento de custos decorrente da remuneração à $\mathrm{COHAB}$ pelo seu serviço como agente operador do Fundo.

Quanto à transparência na gestão dos recursos que, para alguns, teria sido reduzida com a transferência do Fundo para a $\mathrm{COHAB}$, pelo fato de ela não estar conectada ao Sistema de Execução Orçamentária (SEO) da PMSP, a redução que se pode dizer que ocorreu não foi tão considerável, pois a Companhia tem que prestar contas ao Conselho Municipal de Habitação e está sujeita a auditorias do Tribunal de Contas e de empresa independente. Mas também se sugere que a COHAB seja ligada a esse Sistema ou que crie um sistema próprio acessível à população, por exemplo, pela Internet.

Em relação ao Conselho Municipal de Habitação $(\mathrm{CMH})$, são apresentadas sua composição, atribuições e resoluções do período entre sua criação e o final de 2004. E também se discute em torno de algumas visões sobre aspectos positivos ou insuficientes de sua atuação no período mencionado. Entende-se que a conclusão que se pode tirar é que o $\mathrm{CMH}$ é um espaço em construção, cujo exercício mais pleno de suas atribuições dependerá tanto do grau 
de importância que tenha para a administração municipal, quanto do peso político que adquira por ação dos seus conselheiros. A sua atuação efetiva até o limite de suas atribuições, quer seja nas discussões e definições sobre política urbana nos aspectos mais diretamente relacionados à política habitacional, quer seja nas decisões sobre a alocação de todos os recursos destinados a habitação, dependerá, em boa medida, da força com que reivindique a participação nessas decisões. Mas dependerá também de um aperfeiçoamento pela $\mathrm{COHAB}$, do seu instrumental de planejamento e fornecimento de informações ao Conselho.

No Capítulo 5 - A execução pela COHAB-SP da sua parte na política habitacional-, foram analisadas as questões referentes ao estoque de terras disponível, ao processo de aquisição de novas áreas, e ao desenvolvimento dos projetos (arquitetura, urbanismo e engenharia). E também observados os principais programas de provisão habitacional da COHAB, no período 2001-2004: Mutirões com Autogestão, Arrendamento Residencial (PAR), Morar no Centro e Locação Social. Esses foram considerados os principais programas por envolverem ou os maiores números da produção da Companhia (Mutirões e PAR) ou as maiores inovações introduzidas (Morar no Centro e Locação Social).

Nesse capítulo, observa-se a importância que teve, para a implementação das linhas de ação do período 2001-2004, a existência de um estoque de terras, composto, basicamente, de áreas remanescentes em conjuntos habitacionais já implantados pela COHAB e muitas áreas da PMSP dispersas pela cidade. A utilização desse estoque de terras, que predominantemente, situavam-se na Zona Leste e em locais distantes, não permitiu que a COHAB atendesse, exatamente, aos requisitos de boa inserção na malha urbana, que foram propostos no seu Planejamento Estratégico.

O esforço para a obtenção de novas terras demandou um extenso trabalho de levantamentos de campo e de análise documental; de estudos sobre a possibilidade de se adquirir conforme os requisitos da Lei Federal 8666/93, que regulamenta as licitações; e tratativas com a Procuradoria Geral do Município, que resultaram na autorização para que a COHAB passasse a desapropriar imóveis, passando a utilizar um instrumento que havia empregado apenas duas vezes em sua história. 
Também se discute sobre as dificuldades para a obtenção de novas áreas, que decorre de terem se tornado mais escassas e caras; a necessidade mais freqüente de análises sobre a contaminação dos solos e lençóis d'água e sobre a ocorrência de gases tóxicos e/ou explosivos. E sobre a importância de que o Plano Diretor Estratégico, após a revisão a que está sendo submetido, mantenha, se não todas, pelo menos um número significativo das ZEIS e que também haja uma gestão eficiente dessas áreas, visando a aplicação dos instrumentos do Estatuto da Cidade e, efetivamente, viabilizar sua utilização para HIS.

Em relação aos projetos, foi abordada a proposta de que fosse implantado um "novo padrão COHAB de projetos", como reflexo da crítica feita aos tradicionais projetos da COHAB e da bandeira pelo "direito à arquitetura"; e a significativa produção de projetos, tanto em número, quanto em diversidade (tipologias, projetos específicos para áreas livres e para reforma de prédios, etc.), quanto em qualidade. Ressaltando-se nesse último aspecto de que a análise feita não pôde focar aspectos relevantes como o conforto percebido pelos moradores, a racionalidade para as obras, etc. A produção de projetos, além da importância dos produtos (projetos) resultantes, também resulta numa nova experiência sobre a forma de lidar com o processo de produção, que pode continuar a ser utilizada e ampliada e, dessa forma, constituir uma "nova cultura" sobre o quê fazer (produtos) e como fazer (processo).

Quanto aos programas focados neste capítulo, eles são descritos de maneira breve, com informações sobre os papéis dos seus vários agentes, e têm relacionados os empreendimentos que os compõem. A respeito do Programa de Mutirões com Autogestão é colocado um debate que há entre posições que lhe são favoráveis e desfavoráveis; são expostas as várias etapas e gerações do programa; os problemas da primeira geração, durante os governos Maluf e Pitta; o início da segunda e terceira gerações no governo de Marta Suplcy. Discute-se as modificações introduzidas nas suas normas, com ênfase para aquelas relativas aos valores das porcentagens para os vários serviços e dos limites de financiamento, indicando-se mudanças importantes ocorridas no programa em função dessas mudanças de valor. 
E aponta-se para a permanência de dificuldades no processo de prestação de contas, de que decorrem grandes obstáculos para a redução dos prazos de obra, que se constituem (os prazos) num dos aspectos do programa mais sujeito a críticas. E, finalmente, propõe-se um debate franco, "desarmado", visando ao aperfeiçoamento do programa, com a eliminação de arestas do seu regramento e uma utilização mais plena das suas possibilidades "pedagógicas", de estímulo à organização popular, de introdução de melhorias na qualidade de projetos e obras, e de redução de custos.

Em relação ao PAR, são apresentados os procedimentos que foram propostos inicialmente e aqueles, finalmente, adotados; inclusive, os procedimentos relativos à seleção das construtoras por licitação. Coloca-se uma discussão sobre o desempenho das construtoras na montagem dos processos para contratação junto à CEF. Na média, menos ágil do que se esperava e tão pouco inovador nos projetos quanto se esperava. E também uma discussão sobre dificuldades encontradas ao longo do programa, referentes à desocupação de áreas da $\mathrm{COHAB}$, à avaliação dos terrenos, à obtenção da documentação exigida pela CEF relativa aos terrenos, à $\mathrm{COHAB}$ como vendedora e às construtoras, e a uma rigidez nas normativas adotadas pela CEF.

Com atenção especial, são abordados os empreendimentos dos Edifícios São Paulo (antigo Hotel S. Paulo) e São Vito, observando-se as justificativas para as intervenções, as características dos projetos, a desapropriação dos prédios, as tratativas com a CEF, a autorização do $\mathrm{CMH}$ para que se efetuasse a doação dos prédios como um subsídio às famílias e como forma de viabilizar a requalificação de prédios muito degradados e responsáveis, por sua vez, pela degradação de áreas importantes do centro da cidade.

Em relação aos Programas Morar no Centro e de Locação Social, são expostas as fontes de recursos com que se contou para a sua implementação; as razões para que tenham sido criados, como uma resposta ao esvaziamento do centro e à demanda dos movimentos populares. E, no caso da Locação Social, também como uma necessidade de permitir o acesso à moradia a famílias que não dispunham de renda compatível com um financiamento de venda e compra. 
A grande importância do trabalho social e de assessoria à gestão dos "condomínios" 78 no Programa de Locação Social e a forma como estava sendo encaminhada sua realização, também, são analisadas, nesse capítulo, apontandose para problemas surgidos pela interrupção desses trabalhos. Problemas que foram identificados por uma avaliação de pós-ocupação, no caso do Residencial Parque do Gato, e por informações colhidas por funcionários da COHAB, no caso do Conjunto Olarias.

No Capítulo 6 -Alguns paralelos-, são apresentadas uma série de comparações:

- entre o que se propôs e o que se conseguiu realizar,

- entre o que a COHAB-SP realizou de 2001 a 2004 e o que havia feito durante sua história; e também,

- entre as metas colocadas pelo Plano Municipal de Habitação e o que se considerou como uma produção potencial de vários órgãos estatais envolvidos com a provisão de moradia social.

Numa das comparações, verifica-se que a COHAB atingiu 50\% da meta de oferta de un's fixada para no final de 2004, quando se considera a soma de moradias definitivas e transitórias (bolsa-aluguel, etc.), e 41,4\% das metas, quando se considera apenas moradias definitivas. Mas, considerando-se o total de uh's viabilizadas, o número atingido é um pouco superior ao fixado como meta.

Também, pode ser observado que a COHAB, entre 2001 e 2004, se não recuperou um ritmo de entrega de moradias próximo ao dos períodos em que esteve mais ativa, conseguiu sair da quase inércia que marcou a sua atuação, nas gestões de Maluf e Pitta, e viabilizar um número considerável de empreendimentos, iniciando a construção de 9.330 uh's. E, se conservasse esse ritmo, seria possível imaginar que fosse capaz de executar a parte que the caberia (conforme divisão de tarefas suposta por este trabalho) do esforço para atingir as metas do Plano Municipal de Habitação.

\footnotetext{
${ }^{78}$ Efetivamente, ainda não se constituem em condomínios, pois não foi realizada a regularização, a averbação das unidades e a instituição do condomínio.
} 
A formatação e o início execução de novos programas, que é uma coisa cuja dificuldade costuma não ser muito lembrada, foi muito importante. Ou seja, não só se deixou empreendimentos em andamento, como foram deixados novos procedimentos para o início da implementação de novos programas. Nesse aspecto, cabe lembrar de quanto trabalho houve em torno da formulação (e implantação) dos programas Bolsa-Aluguel, Locação Social, Carta de Crédito, de Parceria com a CDHU; da revisão do Programa de Mutirões com Autogestão; das formas de se adquirir e reformar prédios no Centro; das licitações envolvendo o PAR, da criação de um "modus operandi" com a CEF para definição dos valores dos terrenos, aprovação dos projetos, juntada de toda documentação da COHAB necessária para a alienação dos terrenos, e encaminhamento das listas de famílias a serem atendidas no PAR e acompanhamento de sua habilitação. E lembrar inclusive do aperfeiçoamento do "modus operandi" na relação da COHAB com o $\mathrm{FMH} / \mathrm{CMH}$, que partiu da experiência que já havia se acumulado desde a criação do $\mathrm{FMH}$, mas melhorou o instrumental de planejamento e fornecimento de informações ao Conselho.

Outro aspecto importante foi a prospecção de novas fontes de recursos (PAR, CDHU, BID, PEHP, PSH), que deu um fôlego maior para a Companhia e permitiu que (re)adquirisse uma experiência maior nessa área.

Nessas Considerações Finais, um outro ponto que se julga que merece ser lembrado é sobre a necessidade de que haja continuidade de programas e empreendimentos. A busca pela criação de novas "griffes" (CHERKEZIAN, 1998, p. 127) acaba trazendo muitos prejuízos. A longa maturação dos empreendimentos de HIS exige planejamento para prazos maiores do que o de uma gestão e a continuidade dos empreendimentos de uma gestão para outra. Um grande exemplo disso foi a paralisação dos empreendimentos do Programa de Mutirões com Autogestão durante as gestões de Maluf e Pitta. O impacto dessa decisão foi grande para as famílias, para a manutenção da organização das associações e assessorias técnicas (que, em boa medida, foi compensado pela união dos movimentos, que se organizaram em torno do Fórum dos Mutirões), para a COHAB-SP e para o $\mathrm{FMH}$ e seus conselhos, que foram sobrecarregados pelo esforço de equacionamento dos problemas técnicos, legais, econômico-financeiros decorrentes dessa paralisação e, posterior, retomada. 
Considerando essa questão, foi positiva a decisão da gestão 2001-2004 de dar continuidade às obras das gestões anteriores, mesmo aquelas do programa Cingapura, que haviam recebido tantas críticas do PT e de técnicos e acadêmicos ligados à área de habitação. Para atender a essa necessidade de planejamento de longo ou mesmo médio prazo, seria fundamental que se contasse com alguma certeza sobre os recursos que serão alocados no futuro e que haja regularidade na liberação dos recursos aprovados nos orçamentos. Dessa forma, não há como discordar dos setores que propõem uma vinculação de receita à habitação. Apesar de uma vinculação mediante lei ser vedada pela Constituição Federal, ela poderia resultar de um compromisso entre o executivo e o legislativo, de forma semelhante ao que tem ocorrido na destinação de $1 \%$ do ICMS feito pelo Governo do Estado de São Paulo, há várias gestões.

No poema do Drummond na epígrafe, especialmente no trecho: "São 200, são 300 as favelas [........]? tempo de contá-las é tempo de outras surgirem [.......", fica claro o sentimento de serem pouco eficazes as ferramentas de que se dispõe para enfrentar o problema da habitação social. Esse talvez seja o sentimento predominante entre aqueles que atuam nesse setor. Ao focar a experiência da COHAB, durante o período 2001-2004, em que atuou de acordo com uma política habitacional com características novas, este trabalho pretendeu contribuir um pouco para as observações sobre uma das ferramentas disponíveis (a COHAB) e para, quem sabe, ajudar a sua ajustagem, a sua afiação.

\section{Bibliografia}

ABIKO, Alex Kenia. O Papel do Estado na Habitação. Entrevista para o site www. arcoweb.com.br.

AFONSO, Luís Carlos. Justiça fiscal e necessidade de investimentos sociais em um cenário de crise: a administração econômico-financeira no governo Marta Suplicy. In: Gaspar, Akerman, e Garibe. Espaço Urbano e Inclusão 
Social: A Gestão Pública na Cidade de São Paulo. São Paulo: Editora Fundação Perseu Abramo, 2006.

ALBUQUERQUE, Maria José de. Verticalização de Favelas em São Paulo: Balanço de uma experiência. Tese de doutorado. São Paulo: FAUUSP, 2006.

AMARAL, Ângela. Habitação, Participação Popular e Cidadania. Dissertação de mestrado. São Paulo: FAUUSP, 2001.

Avaliação da Política Municipal de Habitação. São Paulo: Instituto Pólis/PUC-SP, 2002.

AMARAL, Paulo José Almeida. Produção da Habitação de Interesse Social na Região Metropolitana de São Paulo: Período 1975-1995. Dissertação de mestrado. São Paulo: FAUUSP, 1999.

Perfil de Necessidades e Projeto de Habitação: Um Estudo de Métodos. Tese de doutorado. São Paulo: FAUUSP, 2005.

APEOP. Informe APEOP. Vários números. São Paulo: APEOP, 2001-2004.

ARANTES, Pedro Fiori. Arquitetura Nova: Sérgio Ferro, Flávio Império e Rodrigo

Lefèvre, de Artigas aos Mutirões. São Paulo: Editora 34, 2004.

ARRETCHE, Marta. Intervenção do Estado e Setor Privado: o Modelo Brasileiro de Política Habitacional. In: Espaço e Debates, nº 31. São Paulo: Núcleo de Estudos Regionais e Urbanos, 1990.

ASCECAP (Associação dos Funcionários da CDHU). Carta ao Governador Mário Covas. São Paulo: ASCECAP, 1998.

AVRITSCHER, Harue Ohara. Aspectos da descontinuidade administrativa no processo de democratização do executivo municipal: São Paulo, 1986 1992. Dissertação de mestrado. São Paulo: EAESP/FGV, 1995.

AZEVEDO, Sérgio e ANDRADE, Luís Aureliano Gama de Andrade. Habitação e Poder: da Fundação da Casa Popular ao Banco Nacional da Habitação. Rio de Janeiro: Zahar Editores, 1982.

AZEVEDO, Sérgio de. Vinte e dois anos de política de Habitação Popular (1964 86): Criação, Trajetória e Extinção do BNH. In RAP - Revista de Administração Pública. Rio de Janeiro, Fundação Getúlio Vargas, 1988. Vol. $22,{ }^{\circ} 4$, p.107/119. 
AZEVEDO, Sérgio de. Os Cenários da Política Habitacional na Década de 90: Dilemas e Perspectivas. Mimeo: comunicação apresentada no II Encontro Nacional da ANPUR. Águas de São Pedro, 1989.

BALL, Michael. O Desenvolvimento do Capitalismo na Provisão da Habitação. In: Espaço e Debates, $n^{\circ}$. 36. São Paulo: Núcleo de Estudos Regionais e Urbanos, 1992.

BASTOS, Maria Alice Junqueira. Pós-Brasília: Rumos da Arquitetura Brasileira. São Paulo: Perspectiva/FAPESP, 2003.

BENEVOLO, Leonardo. História da Arquitetura Moderna. São Paulo: Perspectiva, 1989.

BIDOU-ZACHARIASEN, Catherine. De Volta à Cidade. São Paulo: Annablume, 2006.

BITTAR, Jorge (org.). O Modo Petista de Governar. São Paulo: Partido dos Trabalhadores, 1992.

BLANCO JR., Cid. A Relação Projeto/ Custol Qualidade nos Empreendimentos Habitacionais da Prefeitura de São Paulo - 1989/1992. São Paulo: FAUUSP/ FAPESP, 1996.

BONDUKI, Nabil. Construindo Territórios de Utopia. Dissertação de mestrado. São Paulo: FAUUSP, 1985.

Origens da Habitação Popular no Brasil. São Paulo: Estação Liberdade/ FAPESP, 1998.

Habitar São Paulo: Reflexões Sobre a Gestão Urbana. São Paulo: Estação Liberdade, 2000.

BONDUKI, Nabil (org.). Habitat - As Práticas Bem-Sucedidas em Habitação, Meio Ambiente e Gestão Urbana nas Cidades Brasileiras. São Paulo: Studio Nobel, 1996.

BONDUKI, Nabil; ANDRADE, Carlos; e ROSSETTO, Rossella. Arquitetura e Habitação Social em São Paulo - 1989/1992. São Paulo: IAB/ Fundação Bienal, 1993.

BRAGA, Maria Ângela. Qualidade do Projeto e Qualidade da Habitação: Método de Avaliação. Tese de doutorado. São Paulo: FAUUSP, 1998.

BRANDÃO, Maria Cláudia da Costa. Moradia de Baixa Renda e o Centro Urbano: Qualificação ou Degradação? - O Caso dos Cortiços nas Áreas Centrais 
de São Paulo. Dissertação de mestrado. São Paulo: Instituto de Pesquisas Tecnológicas, 2003.

BUCCI, Maria Paula Dallari. Aspectos Jurídicos do Cooperativismo e das Cooperativas de Habitação no Brasil. Dissertação de mestrado. São Paulo: Faculdade de Direito da USP, 1994.

BUENO, Laura Machado de Mello. Projeto e Favela: Metodologia para Projetos de Urbanização. Tese de doutorado. São Paulo: FAUUSP, 2000.

CAIXA ECONÔMICA FEDERAL. Anexo I ao Edital de Concurso Público. Brasília: CEF, 1998. Manual Técnico de Engenharia. São Paulo: CEF, 2002.

CÂMARA MUNICIPAL DE SÃO PAULO/ GAB. VER. NABIL BONDUKI. Cartilha de Formação sobre o Plano Diretor Estratégico. São Paulo: CMSP, 2002.

CANTERO, João Alberto. A questão da qualidade arquitetônica dimensional e do custo no planejamento habitacional de interesse social: a produção da COHAB-SP na década de 1990. Dissertação de mestrado. São Paulo: FAUUSP, 2004.

CARDOSO, Adauto Lúcio e MOREIRA, Tomás. Habitação: Balanço da política municipal. São Paulo: Instituto Pólis/PUC-SP, 2004.

CARDOSO, Adauto Lúcio e RIBEIRO, Luiz César de Queiroz. A Municipalização das Políticas Habitacionais: Uma Avaliação da Experiência Recente (1993-1996). Rio de Janeiro: IPPUR/UFRJ-FASE.

CARDOSO, Luiz Reynaldo de Azevedo. Construção Habitacional por Mutirão Caracterização, Gerenciamento e Custos. Dissertação de mestrado. São Paulo: Escola Politécnica da USP, 1993. 
CARICARI, Ana Maria e KOHARA, Luiz (orgs.). Cortiços em São Paulo: Soluções Viáveis para Habitação Social no Centro da Cidade e Legislação de Proteção à Moradia. São Paulo: Centro Gaspar Garcia de Direitos Humanos, 2006.

CARPINTÉRO, Marisa V. T.. A construção de um sonho: Os engenheirosarquitetos e a formulação da política habitacional no Brasil. Campinas, Editora da UNICAMP, 1997.

CARVALHO, Caio Santo Amore de. Lupa e Telescópio: O Mutirão em Foco - São Paulo, anos 90 e atualidade. Dissertação de mestrado. São Paulo: FAUUSP, 2004.

CASTRO, Carolina Maria Pozzi de. Papel da Tecnologia na Produção de Habitação Popular- Estudo de Caso: Conjunto Habitacional José Bonifácio. Dissertação de mestrado. São Carlos: Escola de Engenharia de São Carlos USP, 1986.

A Explosão do Autofinanciamento na Produção de Moradia em São Paulo nos Anos 90. Tese de doutorado. São Paulo: FAUUSP, 1999.

CAVALCANTI, Gustavo Vidigal. Uma Concessão ao Passado: Trajetórias da União de Movimentos por Moradia de São Paulo. Dissertação de mestrado. São Paulo: Departamento de Sociologia, FFLCH-USP, 2006.

CDHU. A Oferta Habitacional da CDHU: Evolução e Distribuição na Primeira Década - 1986/1996. São Paulo: CDHU.

Sistema Estadual de Habitação - Textos elaborados pela CDHU de 1994 a 1996, que sintetizam as discussões havidas sobre propostas de Sistema Estadual de Habitação. São Paulo: CDHU.

Manual Técnico de Projetos. São Paulo: CDHU.

CHERKEZIAN, Henry e BOLAFFI, Gabriel. Os Caminhos do Mal-Estar Social: Habitação e Urbanismo no Brasil. In: Novos Estudos, $n^{\circ}$. 50. São Paulo: CEBRAP, março/1998.

COHAB-SP. Plano Trienal 1970/1972. São Paulo: mimeo, 1969

Política e Proposta de Ação. Salvador: III Seminário Nacional de COHAB's, mimeo, 1979.

Dossiê: A Verdade sobre a COHAB. São Paulo: COHAB-SP, 1989. 
COHAB-SP. Relatório de Gestão - 1989/1992. São Paulo: COHAB-SP, 1992.

Relatório Zero. São Paulo: COHAB-SP, 2001.

Planejamento Estratégico. São Paulo: COHAB-SP, 2001.

Relatório de Gestão 2001-2004. São Paulo: COHAB-SP, 2004.

COMAS, Carlos Eduardo Dias. O Espaço da Arbitrariedade. Considerações sobre o Conjunto Habitacional BNH e o Projeto de Cidade Brasileira. In: Revista Projeto, nº 91. São Paulo: Ed. Projeto, 1986.

CONSTANTINO, Carlos Adriano Santos Constantino e CASTRO, Carolina Maria

Pozzi. Análise Comparativa de Custos de Produção dos Programas Habitacionais de HABI, no período 1989-1992. Mimeo. São Paulo: FAUUSP, 1994.

CONSTANTINO, Lygia Gonçalves. Habitação Popular em Campinas: Ação e Identidade. Tese de doutorado. São Paulo: FAUUSP,1997.

$\mathrm{CORCH}$, Jacob Aron. Participação Comunitária no Projeto, Construção e Gestão de Conjuntos Habitacionais Produzidos por Mutirão. Dissertação de mestrado. São Paulo: FAU-Universidade Mackenzie, 2001.

COSTA, José Roberto S. M.. Estrutura de Financiamentos Habitacionais Praticados em Alguns Países Selecionados. Dissertação de mestrado. São Paulo: Instituto de Pesquisas Tecnológicas, 2004

CYMBALISTA, Renato e MOREIRA, Tomás. O Conselho Municipal de Habitação em São Paulo. São Paulo: Instituto Pólis/PUC-SP, 2002.

D'ALESSANDRO, Maria Lúcia Salum. Avaliação da Política de Urbanização de Favelas em São Paulo no período 1989/1992. Dissertação de mestrado. São Paulo: Fundação Getúlio Vargas/ Escola de Administração de Empresas de São Paulo, 1999.

DANIEL, Celso. As Eleições de 82 - O PT e a Questão Municipal. São Paulo: Partido dos Trabalhadores, 1981.

DENALDI, Rosana. Políticas de Urbanização de Favelas: Evolução e Impasses. Tese de doutorado. São Paulo: FAUUSP, 2003.

DOMINGUES, Roberto Manoel. Intercorrências em Zonas Vocacionadas para Habitação de Interesse Social nas Áreas Centrais da Cidade de São Paulo: Desapropriação, Custo da Terra, Plano Diretor. Dissertação de mestrado. São Paulo: Instituto de Pesquisas Tecnológicas, 2004. 
HUET, Bernard. A Cidade como Espaço Habitável - Alternativas à Carta de Atenas. In: Arquitetura e Urbanismo, dez/jan 1986/1987, pg. 82-87.

FARAH, Marta. Público e Privado na Provisão de Habitações nos Países Centrais. In: Espaço e Debates, $n^{\circ}$. 31. São Paulo: Núcleo de Estudos Regionais e Urbanos, 1990.

Tecnologia, Processo de Trabalho e Construção Habitacional. Tese de doutorado. São Paulo: FFLCH-USP, 1992.

Indústria da Construção e Habitação: a Perspectiva do Consumo. In Construção São Paulo, n 2368. São Paulo: Editora Pini, junho/1993.

Processo de Trabalho na Construção Habitacional: Tradição e Mudança. São Paulo: Annablume,1996.

FELIPE, Joel Pereira. Mutirão e Autogestão no Jardim São Francisco (19891992): Movimento de Moradia, Lugar do Arquiteto. Dissertação de mestrado. São Carlos: EESC-USP, 1997.

FERREIRA, Luiz Paulo Teixeira. O Direito à Moradia na Constituição Brasileira, o Sistema de Garantia na Legislação e a Experiência de São Paulo. Dissertação de mestrado. São Paulo: Faculdade de Direito da USP, 2006. Política Habitacional Urbana. In: Gaspar, Akerman, e Garibe. Espaço Urbano e Inclusão Social: A Gestão Pública na Cidade de São Paulo. São Paulo: Editora Fundação Perseu Abramo, 2006.

FIABCI/ BRASIL. Proposta da Fiabcil Brasil para o Desenvolvimento da Habitação Popular. Mimeo. São Paulo: 2002.

FIESP/ CIESP. ConstruBusiness 2001. São Paulo: FIESP/ CIESP, 2001.

FIGUEIREDO, Angelina M.C. e FIGUEIREDO, Marcus F. Avaliação Política e Avaliação de Políticas: um quadro de referência teórica. São Paulo, IDESP, 1986.

FONTES, Maria Cecília Levy Piza. Produção Habitacional de Interesse Social no Município de São Paulo - Estudo de Caso: Gleba N de Heliópolis. Dissertação de mestrado. São Paulo, FAU/Univ. Mackenzie, 2005.

FORATO, Sylvia Ammar. Habitação e Meio Ambiente em São Paulo: o Projeto

Cingapura. Dissertação de Mestrado. São Paulo, PROCAM-USP.

FURIGO, Renata de Faria Rocha. Redes de Esgoto em Favelas Urbanizadas: Avaliação de Desempenho e Parâmetros para Projeto. Dissertação de mestrado. São Paulo: Faculdade de Saúde Pública da USP, 2003. 
GITAHY, Maria Lúcia e PEREIRA, Paulo César Xavier (orgs.). O Complexo Industrial da Construção e a Habitação Econômica Moderna: 1930-1964. São Carlos: RiMa, 2002.

GHOUBAR, Khaled. Custe o que Custar. Tese de doutorado. São Paulo: FAUUSP, 1987.

Sobre a Falta de Visibilidade dos Custos no Projeto Arquitetônico. Tese de Livre Docência. São Paulo: FAUUSP, 1999.

Indicadores de Custos de Empreendimentos Habitacionais para seu Redesenho. Exposição no Seminário de Pesquisa: "Políticas Habitacionais, Produção de Moradia por Mutirão e Processos Autogestionários: Balanço Crítico de Experiências em São Paulo, Belo Horizonte e Fortaleza". São Paulo: Usina/ FAUUSP, 19 de Outubro de 2004.

GORDILHO-SOUZA, Ângela (org.). Habitar Contemporâneo: Novas Questões no

Brasil dos Anos 90. Salvador, UFBA/ Lab-Habitar, 1997.

HARVEY, David. O Trabalho, o Capital e o Conflito em Torno do Ambiente Construído nas Sociedades Capitalistas Avançadas. In Revista Espaço e Debates. São Paulo: Cortez, 1982.

Condição Pós-Moderna. São Paulo: Edições Loyola, 1994.

HEREDA, Jorge. Habitação Popular - O Discurso e a Prática - 0 Caso de Diadema. In: GORDILHO-SOUZA, Ângela (org.). Habitar Contemporâneo: Novas Questões no Brasil dos Anos 90. Salvador, UFBA/ Lab-Habitar, 1997.

HUET, Bernard. A Cidade como Espaço Habitável. In: Revista AU. São Paulo, dezembro/1986-janeiro/1987.

INSTITUTO CIDADANIA. Projeto Moradia. São Paulo: Instituto Cidadania, 2000.

JUSTEN FILHO, Marçal. Comentários à Lei de Licitações e Contratos Administrativos. São Paulo: Dialética, 2001.

KAYANO, Jorge; SOUTO, Ana Luiza Salles; ALMEIDA, Marco Antonio de; e PETRUCCI, Victor Augusto. Como reconhecer um bom governo?. São Paulo: Revista Pólis, nº 21, 1995.

KFOURI, Antônio Carlos. Pré-Fabricação, Verticalização e Gestão Popular no Canteiro de Obras da Habitação. Dissertação de mestrado. São Paulo: FAUUSP, 1996.

KLEIN, Alexander. Vivienda Minima: 1906-1957. Barcelona: Gustavo Gili, 1980. 
KOHARA, Luiz Tokuzi. Rendimentos Obtidos na Locação e Sublocação de Cortiços - Estudos de Caso na Área Central da Cidade de São Paulo. Dissertação de mestrado. São Paulo: Escola Politécnica da USP, 1999.

KOWARICK, Lúcio. Escritos Urbanos. São Paulo: Editora 34, 2000.

LABHAB. Preço de Desapropriação de Terras. (relatório de pesquisa). São Paulo: LABHAB/ FAUUSP, 2001.

LEFEBVRE, Henry. O Direito à Cidade. São Paulo: Editora Moraes, 1991.

LEE, Kyung Mi. Uma Proposta para Avançar nas Questões de Sustentabilidade para Habitação de Interesse Social. Tese de doutorado. São Paulo: FAUUSP, 2005.

LOZANO, José Wilson. Custo de Edificações de Conjuntos Habitacionais em Áreas Faveladas do Projeto Cingapura. Dissertação de mestrado. São Paulo: IPT, 2004.

MAGNAVITA, Luis. COHAB-SP - Capital: 1965-1990: Processos Construtivos/ Análise de uma Questão sem Resposta. Dissertação de mestrado. São Carlos: Escola de Engenharia de São Carlos/ USP, 1994.

MALERONKA, Camila. PAR-Reforma: Quem se Habilita? - A Viabilização de Empreendimentos Habitacionais em São Paulo Através do Programa de Arrendamento Residencial - Modalidade Reforma: 1999-2003. Dissertação de mestrado. S. Paulo: IPT, 2005.

MARICATO, Ermínia. Política Habitacional no Regime Militar. Petrópolis: Vozes, 1987.

Metrópole na Periferia do Capitalismo - Ilegalidade, Desigualdade e Violência. São Paulo: Editora Hucitec, 1996.

Enfrentando Desafios: A Política Desenvolvida pela Secretaria de Habitação da Prefeitura de São Paulo - 1989/1992. Tese de Livre Docência. São Paulo: FAUUSP, 1997.

MARICATO, Ermínia e PEDROSA, José Álvaro. Habitação e Meio Ambiente: Um Desastre Chamado Conjunto Habitacional Santa Etelvina. Texto revisado do paper "The Quality of the Built Environment of Popular Housing in Brasil", publicado nos anais da XI Bartlett International Summer School. London, University College London, 1991. 
MARQUES, Eduardo e SARAIVA, Camila. As Políticas de Habitação Social, a Segregação e as Desigualdades Sociais na Cidade. In: MARQUES, Eduardo e TORRES, Haroldo (orgs.). São Paulo: Segregação, Pobreza e Desigualdades Sociais. São Paulo: Editora SENAC São Paulo, 2005.

MASCARÓ, Juan. O Custo das Decisões Arquitetônicas. São Paulo: Nobel, 1985. MELLO, Marcus André B. C. de. Classe, Burocracia e Intermediação de Interesses na Formação da Política de Habitação. In: Espaço e Debates, n. 24. São Paulo: Núcleo de Estudos Regionais e Urbanos, 1988.

Estruturação Intra-Urbana, Regimes de Acumulação e Sistemas Financeiros da Habitação: Brasil em Perspectiva Comparada. In: Espaço e Debates, $n^{\circ}$. 31. São Paulo: Núcleo de Estudos Regionais e Urbanos, 1990. MOREIRA, Tomás. A política habitacional e fundiária no Brasil. Seminário: Terra urbana para políticas sociais: aquisição e desapropriação, LabHab e Lincoln Institute of Land Policy. São Paulo: 2002.

http://www.usp.br/fau/docentes/depprojeto/c deak/AUP272/4bd/txt/t4tomas.doc.

MORETTI, Ricardo. Normas Urbanísticas para Habitação de Interesse Social Recomendações para Elaboração. São Paulo: IPT, 1997.

MOTTA,, Caio Attadia da (coord.). Nível de Satisfação em Conjuntos Habitacionais da Grande São Paulo. São Paulo: IPT/FAPESP, 1975.

NAKANO, Anderson Kazuo. 4 COHAB's da zona leste de São Paulo: território, poder e segregação. Dissertação de mestrado. São Paulo, FAUUSP, 2002.

NOGUEIRA, Aída Pompeo. O Habitar no Espaço Urbano Periférico: Conjuntos de Habitação Social. Tese de doutorado. São Paulo: FAUUSP, 2003.

OLIVEIRA, Francisco. Conferência: "Papel da Autoconstrução para a Acumulação Capitalista no Brasil”. Apresentada no Seminário de Pesquisa: "Políticas Habitacionais, Produção de Moradia por Mutirão e Processos Autogestionários: Balanço Crítico de Experiências em São Paulo, Belo Horizonte e Fortaleza". São Paulo: Usina/ FAUUSP, 18 de Outubro de 2004.

Crítica à Razão Dualista e O Ornitorrinco. São Paulo: Boitempo Editorial, 2003.

OLIVEIRA, Nelson de. Cenas de Favela: As melhores histórias da periferia brasileira. Rio de Janeiro: Geração Editorial, 2007 
OLIVEIRA, Zenaide Machado. Alcance e Limites de Uma Política Setorial de Âmbito Estadual: a Política de Habitação de Interesse Social do Estado de São Paulo, de 1984 a 2000. Dissertação de mestrado. Campinas, UNICAMP/ Instituto de Economia, 2002.

PARTIDO DOS TRABALHADORES. Resoluções de Encontros e Congressos: 1979-1998. São Paulo: Editora Fundação Perseu Abramo, 1998.

PIGNANELLI, Paulo Eduardo Barros. Origens Históricas e Involução da Arquitetura: os Últimos Vinte Anos de Projetos da CDHU. Dissertação de mestrado. São Paulo: FAUUSP, 2003.

PMSP. Decreto 84.049/94 - Sobre Habitação de Interesse Social. São Paulo: PMSP, 1994.

Lei n 11.632/94 - Institui o FMH. São Paulo: PMSP, 1994.

Lei $n^{\circ}$ 13.425/02 - Extingue o Conselho do FMH e cria o Conselho Municipal de Habitação. São Paulo: PMSP, 2002.

PMSP/ SEHAB. Política Municipal de Habitação. São Paulo: SEHAB, 2001.

Resoluções do Conselho do FMH. São Paulo: PMSP, de 1997 a 2002.

Plano de Metas do FMH. São Paulo: SEHAB, 2002.

Atas das Reuniões do Conselho do FMH. São Paulo: SEHAB, 2001/2002.

Plano de Ação da SEHAB. São Paulo: SEHAB, 2003.

Balanço Qualitativo de Gestão 2001-2004. São Paulo: SEHAB, 2004.

Plano Municipal de Habitação. São Paulo: SEHAB, 2004.

PMSP/ SEHAB/ HABI. Relatório de Gestão - 1989/ 1992. São Paulo: HABI, 1992.

PMSP/ SEHAB/ RESOLO. Resolo - Regularização de Loteamentos no Município

de São Paulo. São Paulo: Portela Boldarani Arquitetura e Urbanismo, 2003.

PRESIDÉNCIA DA REPÚBLICA DO BRASIL. Lei do Parcelamento do Solo Urbano - n 9785 de 29/01/99. Brasília: Presidência da República do Brasil, 1999.

Estatuto da Cidade - Lei n 10.527I 2001. Brasília: CONFEA, 2002.

RIBEIRO, L. C. e AZEVEDO, S. A Crise da Moradia nas Grandes Cidades. Da

Questão da Habitação à Reforma Urbana. Rio de Janeiro: 1998.

ROLNIK, Raquel. A Cidade e a Lei. São Paulo: Nobel, 1997. 
RONCONI, Reginaldo. Habitações Construídas com Gerenciamento pelos Usuários, com Organização da Força de Trabalho em Regime de Mutirão - O Programa FUNAPS Comunitário. Dissertação de mestrado. São Carlos: EESC-USP, 1995.

ROSSETTO, Rossella. Fundo Municipal de Habitação. São Paulo: Instituto Pólis/PUC-SP, 2003.

ROYER, Luciana. Política Habitacional no Estado de São Paulo: Estudo sobre a Companhia de Desenvolvimento Habitacional e Urbano do Estado de São Paulo. Dissertação de mestrado. São Paulo: FAUUSP, 2003.

RUBANO, Lizete Maria. Cultura de projeto: um estudo de idéias e propostas para habitação coletiva. Tese de doutorado. São Paulo: FAUUSP, 2001.

RUPRECHT, Denise Gomes César. Conjunto Habitacional Jundiaí-A: Dois Modos de Arquitetar. Dissertação de mestrado. São Paulo: FAUUniversidade Mackenzie, 2003.

SACHS, Céline. São Paulo: Políticas Públicas e Habitação Popular. Trad. de Cristina Murachco. São Paulo: Editora da Universidade de São Paulo, 1999.

SADER, Eder. Quando Novos Personagens Entram em Cena. Rio de Janeiro: Editora Editora Paz e Terra, 1988.

SADER, Emir. Governar para Todos: uma avaliação da gestão Luiza Erundina. $1^{\text {a }}$ edição. São Paulo: Scritta Editorial, 1992.

SANT'ANA, Daniela Glizt. A influência da escala de compras de materiais de construção em um empreendimento habitacional de interesse social: Projeto PR5-2QT - Caixa Econômica Federal. Dissertação de mestrado. São Paulo: Instituto de Pesquisas Tecnológicas, 2005.

SANTOS, Cynthia de Souza. A política habitacional para população de baixa renda, em Belo Horizonte. Tese de doutorado: São Paulo: FAUUSP, 2006.

SEADE/CDHU. Análise da Regularidade de Ocupação das Unidades Habitacionais Comercializadas no Município de S. Paulo. São Paulo: CDHU, 2000.

SEDU. Istambul + 5 - Relatório Nacional Brasileiro. Brasília: Secretaria Especial de Desenvolvimento Urbano da Presidência da República, 2001.

SILVA, Ana Amélia da (org.). Moradia e Cidadania: Um Debate em Movimento. In Pólis, n²0. São Paulo: Pólis, 1994. 
SILVA, Helena Menna Barreto e CASTRO, Carolina Maria Pozzi de. A Legislação, O Mercado e o Acesso à Habitação em São Paulo, texto apresentado no Workshop "Habitação: Como Ampliar o Mercado?". São Paulo: IPT/USP, 1997.

SILVA, Helena Menna Barreto. Terra e Moradia: que papel para o município? Tese de doutorado. São Paulo: FAUUSP, 1997.

O Centro de São Paulo: que futuro para a habitação. Mimeo. S. Paulo: 2001.

SILVA, Maria da Graça Plenamente. A "irregularidade" na produção de conjuntos habitacionais de interesse social: o caso COHAB-SP. Dissertação de mestrado. São Paulo: FAUUSP, 2004.

SILVA, Ricardo Toledo. Habitação, Infra-estrutura e Regulação Pública: Limites da Privatização. Tese de doutorado. São Paulo: FAUUSP, 1991.

SINDUSCON. Janela. Vários números. São Paulo: Folha de São Paulo, 2001-2004.

SINDUSCON. Habifax. Vários números. São Paulo: www.sindusconsp.com.br, 2001-2004.

SINGER, Paul. Economia Política da Urbanização. 11ª . edição. São Paulo: Editora Brasiliense, 1987.

Um Governo de Esquerda para Todos. São Paulo: Brasiliense, 1996.

SLOMIANSKY, Adriana Paula. Cidade Tiradentes: A Abordagem do Poder Público na Construção da Cidade - Conjuntos Habitacionais de Interesse Social da COHAB-SP (1965/1999). Tese de doutorado. São Paulo: FAUUSP, 2002.

SOMEKH, Nádia; CAMPOS, Cândido Malta; WILDERODE, Daniel Van. Mercado Imobiliário e Política Urbana: AEIS de Diadema.

Trabalho apresentado no II Seminário Internacional da LARES - Latin

American Real Estate Society. São Paulo,

http://www.lares.org.br/SL2 somekh1.pdf, setembro/2001.

VARGAS, Nilton. Organização do trabalho e capital - um estudo da construção habitacional. Dissertação de mestrado. Rio de Janeiro: COPPE/UFRJ, 1979. Racionalidade e Não Racionalização: o Caso da Construção Habitacional. In: VARGAS, N. e FLEURY, A. C. C. "Organização do Trabalho". São Paulo: Editora Atlas, 1983. 
VIEIRA, Maurício Monteiro Almeida. Oferta de Habitação de Interesse Social na Área Central de São Paulo: Contribuições para o Aprimoramento dos Processos a Partir da Avaliação de Pós-Ocupação. Tese de Doutorado. São Paulo: FAUUSP, 2005.

VIEIRA, Núria Pardillos. Produção de Habitações pelo Regime de Mutirão com Autogestão na Cidade de São Paulo - Balanço e Indicadores de Avaliação - trabalho para a disciplina História da Habitação Social no Brasil, do Centro Tecnológico da UFRN. Natal: mimeo, dezembro/ 2005.

WATANABE, Mário. O Desafio de Privatizar a Moradia Popular. In: Qualidade na Construção, $n^{\circ}$ 22. São Paulo: SindusCon, 2000.

WERNA, Edmundo; ABIKO, Alex; COELHO, Leandro; SIMAS, Rubenio; KEIVANI, Ramin; HAMBURGER, Diana; ALMEIDA, Marco Antônio. Pluralismo na Habitação. São Paulo: Annablume, 2001.

YOLLE NETO, José. Diretrizes para o Estudo da Viabilidade da Reabilitação de Edifícios Antigos na Região Central de S. Paulo, Visando a Produção de HIS. Dissertação de mestrado. São Paulo: Poli/USP, 2006 